\title{
INFLUÊNCIA DA PRESERVAÇÃO CONTRA A DEMANDA BIOLÓGICA EM PROPRIEDADES DE RESISTÊNCIA E DE ELASTICIDADE DA MADEIRA
}

Roberto Vasconcelos Pinheiro

Tese apresentada à Escola de Engenharia de São Carlos, da Universidade de São Paulo, como parte dos requisitos para obtenção do título de Doutor em Engenharia de Estruturas

ORIENTADOR: Prof. Titular Francisco A. Rocco Lahr 


\section{AGRADECIMENTOS}

À DEUS, pela saúde e sabedoria concedida em todas as etapas da minha vida.

Ao professor e amigo Francisco Antonio Rocco Lahr e à sua família pelo companheirismo, compreensão e pela formação humana e profissional prestada ao longo dos últimos 11 anos, além de colaborar imensamente durante todo o desenvolvimento deste trabalho.

À Coordenadoria de Aperfeiçoamento de Pessoal de Nível Superior CAPES, pela bolsa de ensino concedida.

Ao Centro Universitário "Moura Lacerda” pelo auxílio financeiro concedido.

À Universidade de Franca pela confiança demonstrada.

Ao grande amigo Chico "Mineiro" que efetivamente auxiliou e contribuiu para a conclusão da pesquisa.

Às famílias dos grandes amigos Luís Márcio Faleiros, Luiz Márcio Silveira, Orlando e Júlio Cheade que, mesmo indiretamente, através do carinho mostrado, puderam contribuir para o desenvolvimento do trabalho.

Aos demais amigos que puderam contribuir com a simpatia e generosidade.

Aos professores de maneira geral, que de alguma maneira contribuíram para o desenvolvimento deste trabalho.

Um agradecimento especial aos Professores Dagoberto D. Mori e Antonio A. Dias “Nabão", que muito me auxiliaram na carreira docente. 
A todos os funcionários e colegas do LaMEM pela colaboração direta e indireta, bem como pela agradável convivência. Um agradecimento especial aos técnicos Jaime, Cido, Sílvio e Arnaldo, pela amizade e disposição demonstrada durante o desenvolvimento da pesquisa. 
Aos meus pais Rubens e Neuza, mesmo estando "distantes", puderam contribuir para que esta sonhada etapa de minha vida pudesse ser concluida. 
À ANA LÚCIA, esposa e companheira que amo tanto, pela dedicação e carinho demonstrado ao longo dos anos.

A minha filha GRAZIELA, por representar a esperança de um mundo melhor e ser a prova da cumplicidade e da harmonia de um grande "AMOR". 


\section{SUMÁRIO}

LISTA DE FIGURAS.................................................................. i

LISTA DE TABELAS......................................................................... ii

LISTA DE ABREVIATURAS E SIGLAS............................................. ix

LISTA DE SÍMBOLOS....................................................................

RESUMO.............................................................................. xii

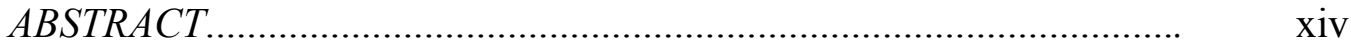

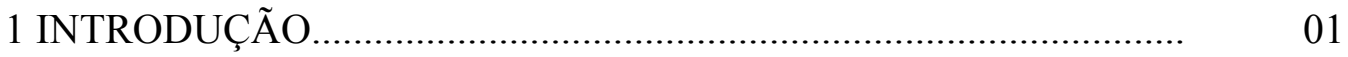

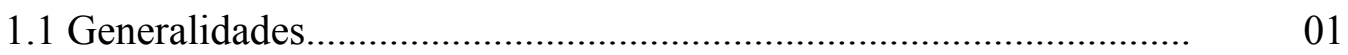

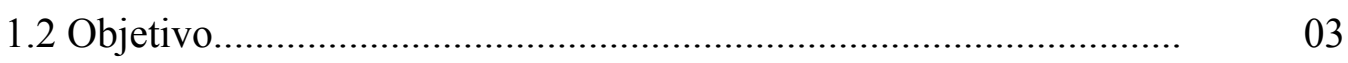

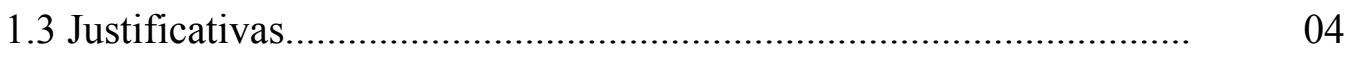

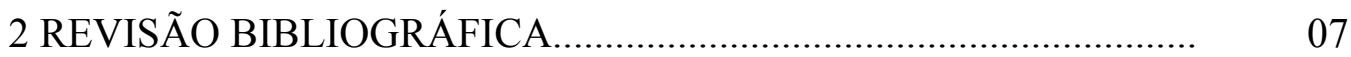

2.1 Recursos florestais brasileiros.............................................................. 07

2.1.1 Aspectos gerais referentes às matas nativas....................................... 07

2.1.1.1 Descrição resumida das espécies nativas 08 utilizadas

2.1.2 Aspectos gerais referentes às matas de reflorestamento...................... 13

2.1.2.1 Descrição resumida das espécies de reflorestamento 15 utilizadas......

2.2 Madeira: material de construção........................................................... 18

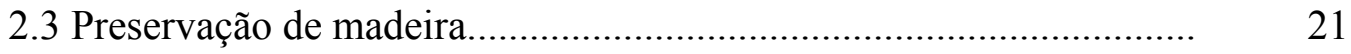

2.3.1 Tipos de preservação.....................................................................

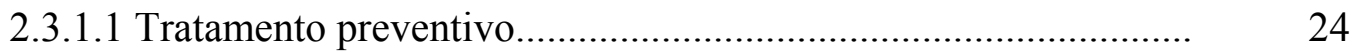

2.3.1.1.1 Pré-tratamento.................................................................... 
2.3.1.1.2 Processo não-industrial ou sem vácuo/pressão............................ 25

2.3.1.1.3 Processo industrial ou à vácuo/pressão...................................... 27

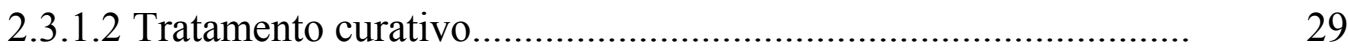

2.3.2 Classificação dos preservativos químicos........................................ 30

2.3.2.1 Arseniato de cobre cromatado (CCA).......................................... 30

2.3.2.2 Sais de cobre, cromo e boro (CCB)............................................ 32

2.3.3 Panorama da preservação no Brasil............................................... 32

2.4 Deterioração da madeira................................................................ 35

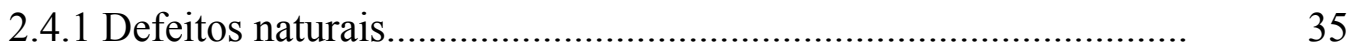

2.4.2 Agentes deterioradores.......................................................... 36

2.4.2.1 Agentes abióticos.................................................................. 36

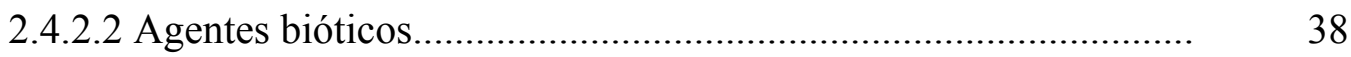

2.5 Propriedades da madeira............................................................... 41

2.5.1 Propriedades físicas........................................................................ 43

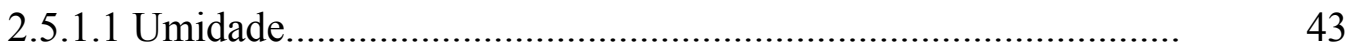

2.5.1.2 Estabilidade dimensional (retratibilidade ou 44 inchamento).

2.5.1.3 Massa específica aparente e densidade básica.............................. 45

2.5.2 Propriedades mecânicas (resistência e 45 elasticidade).

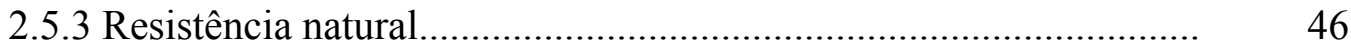

2.6 Preservação x Propriedades mecânicas................................................ 46

2.7 Comentários referente a revisão bibliográfica 53 realizada.

3 MATERIAIS E MÉTODOS...................................................... 54

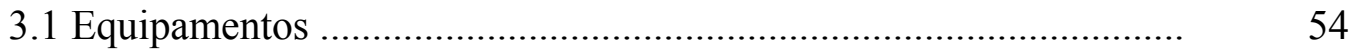

3.1.1 Instrumentos de medição.......................................................... 54

3.1.2 Equipamentos para aplicação de forças.......................................... 55

3.1.3 Equipamentos para secagem e climatização................................... 55

3.2 Materiais de consumo.................................................................. 55

3.2.1 Espécies de madeira..................................................................... 56 
3.2.1.1 Seleção das espécies.................................................................. 56

3.2.2 Produtos preservativos............................................................ 56

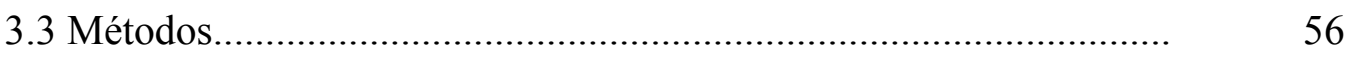

3.3.1 Determinação das propriedades físicas da madeira........................... 56

3.3.2 Determinação das propriedades mecânicas da madeira..................... 57

3.3.3 Processo de preservação................................................................ 59

3.3.4 Procedimento experimental........................................................ 59

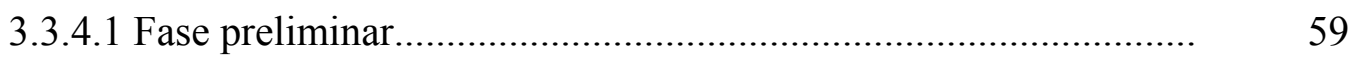

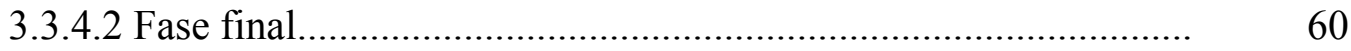

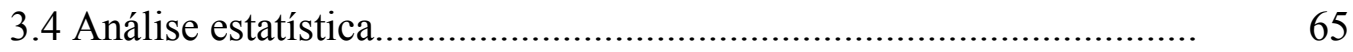

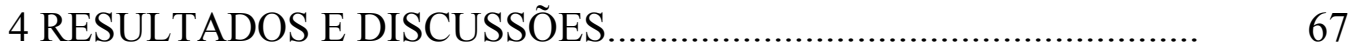

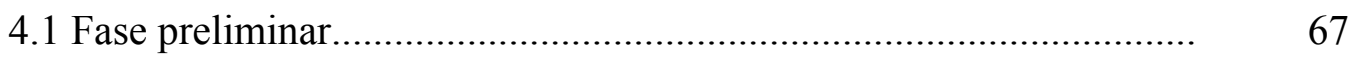

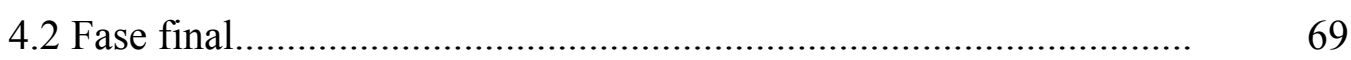

4.2.1 Espécies nativas....................................................................... $\quad 70$

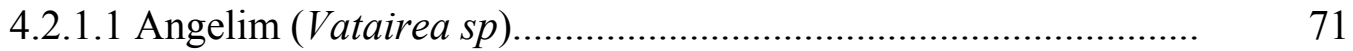

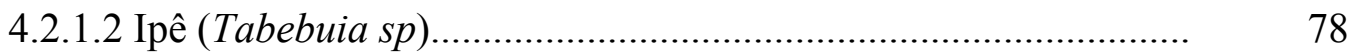

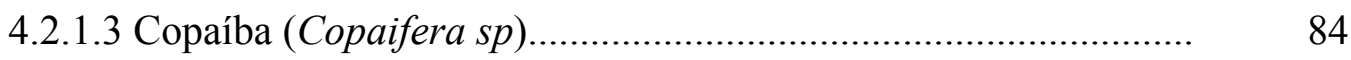

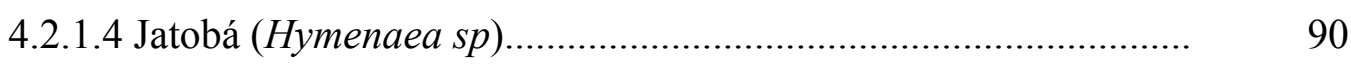

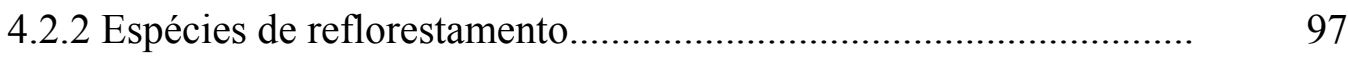

4.2.2.1 Eucalipto Grandis (Eucalyptus grandis)................................... 97

4.2.2.2 Pinus Ellioottii (Pinus elliottii).................................................. 112

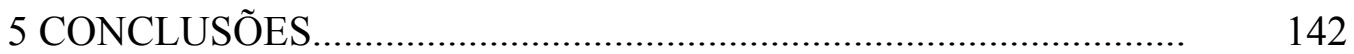

REFERÊNCIAS BIBLIOGRÁFICAS................................................. 148 


\section{LISTA DE FIGURAS}

FIGURA 01 - Corte longitudinal - Angelim (Vatairea $s p$ ).......................... 09

FIGURA 02 - Corte longitudinal - Garapa (Apuleia leiocarpa)................... 10

FIGURA 03 - Corte longitudinal - Ipê (Tabebuia sp).................................. 11

FIGURA 04 - Corte longitudinal - Jatobá (Hymenaea sp).......................... 11

FIGURA 05 - Corte longitudinal - Pau-amarelo (Euxylophora paraensis).. 12

FIGURA 06 - Corte longitudinal - Copaíba (Copaifera $s p$ )......................... 12

FIGURA 07 - Corte longitudinal - Pinus (Pinus $s p$ )................................... 17

FIGURA 08 - Corte longitudinal - Eucalipto Grandis (Eucaliptus grandis) 18

FIGURA 09 - CP de compressão paralela às fibras..................................... 57

FIGURA 10 - Equipamento de ensaio - compressão paralela às fibras........ 57

FIGURA 11 - CP de cisalhamento paralelo às fibras................................. 58

FIGURA 12 - Equipamento de ensaio - cisalhamento paralelo às fibras.... 58

FIGURA 13 - CP e equipamento de ensaio - tração paralela às fibras......... 58

FIGURA 14 - Gabarito de obtenção dos CP's da fase preliminar............... 59

FIGURA 15 - Gabarito de obtenção dos CP's da fase final (1 $1^{\mathrm{a}}$ etapa)......... 62

FIGURA 16 - Diagrama de Kollmann......................................................... $\quad 70$

FIGURA 17 - Módulo de elasticidade longitudinal do Angelim (regressão linear simples).................................................. 73

FIGURA 18 - Módulo de elasticidade longitudinal do Ipê (regressão linear simples) ........................................................... 80

FIGURA 19 - Módulo de elasticidade longitudinal da Copaíba (regressão

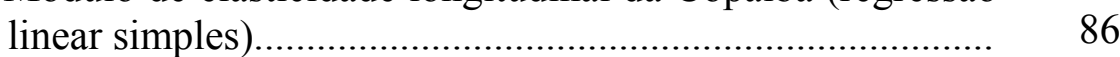

FIGURA 20 - Módulo de elasticidade longitudinal do Jatobá (regressão linear simples) ............................................................ 92

FIGURA 21 - Módulo de elasticidade longitudinal do Eucalipto Grandis (regressão linear simples).

FIGURA 22 - Módulo de elasticidade longitudinal do Pinus Elliottii (regressão linear simples). 


\section{LISTA DE TABELAS}

TABELA 01 - Proporção entre os componentes ativos - CCA................ 32

TABELA 02 - $\quad$ Proporção entre os componentes ativos - CCB................ 32

TABELA 03 - Classificação das madeiras segundo sua durabilidade natural................................................................. 46

TABELA 04 - $\quad$ Método de aplicação e categorias de preservação............ $\quad 50$

TABELA 05 - $\quad$ Ensaios realizados na primeira etapa - espécies nativas... 63

TABELA 06 - Ensaios realizados na segunda etapa - Pinus Elliottii...... 64

TABELA 07 - Ensaios realizados na segunda etapa - Eucalipto Grandis 64

TABELA 08 - Valores das propriedades de resistência e rigidez coníferas................................................................ 67

TABELA 09 - Valores das propriedades de resistência e rigidez dicotiledôneas................................................................ 68

TABELA 10 - $\quad$ Parâmetros estatísticos......................................................... 69

TABELA 11 - Resistência característica à compressão e ao cisalhamento paralelo - Angelim.

TABELA 12 - Valores individuais de resistência à compressão paralela e ao cisalhamento paralelo - Angelim.............................. 72

TABELA 13 - Parâmetros estatísticos para resistência à compressão paralela - Angelim..................................................... 72

TABELA 14 - Parâmetros estatísticos para resistência ao cisalhamento paralelo - Angelim 2 6 0 63 64 67 68 69 1 72

TABELA 15 - Valores individuais de rigidez à compressão paralela NBR 7190/97 - Angelim................................................. 74

TABELA 16 - Valores individuais de rigidez à compressão paralela LOGSDON (1998) - Angelim.

TABELA 17 - Parâmetros estatísticos para rigidez à compressão paralela - Angelim........................................................

TABELA 18 - Relação da resistência e da rigidez entre CP's preservados (CCA) e naturais (sem preservação) Angelim.

TABELA 19 - Parâmetros estatísticos da relação da resistência e da rigidez entre os CP's preservados (CCA) e naturais (sem preservação) - Angelim. 
TABELA 20 - Fator K - efeito do preservativo e do processo de tratamento nas propriedades mecânicas da madeira Angelim

TABELA 21 - Resistência característica à compressão e ao cisalhamento paralelo - Ipê..............................................

TABELA 22 - Valores individuais de resistência à compressão e ao cisalhamento paralelo - Ipê.

TABELA 23 - Parâmetros estatísticos para resistência à compressão paralela - Ipê.

TABELA 24 - Parâmetros estatísticos para resistência ao cisalhamento paralelo - Ipê.

TABELA 25 - Valores individuais de rigidez à compressão paralela NBR 7190/97 - Ipê.

TABELA 26 - Valores individuais de rigidez à compressão paralela LOGSDON (1998) - Ipê.

TABELA 27 - Parâmetros estatísticos para rigidez à compressão paralela - Ipê.

TABELA 28 - Relação da resistência e da rigidez entre CP's preservados (CCA) e naturais (sem preservação) - Ipê....

TABELA 29 - Parâmetros estatísticos da relação da resistência e da rigidez entre CP's preservados (CCA) e naturais (sem preservação) - Ipê.....

TABELA 30 - Fator $\mathrm{K}$ - efeito do preservativo e do processo de tratamento nas propriedades mecânicas da madeira - Ipê

TABELA 31 - Resistência característica à compressão e ao cisalhamento paralelo - Copaíba.

Valores individuias de resistência à compressão e ao

TABELA 32 cisalhamento paralelo - Copaíba.

TABELA 33 - $\quad$ Parâmetros estatísticos para resistência à compressão paralela - Copaíba.

TABELA 34 - $\quad$ Parâmetros estatísticos para resistência ao cisalhamento paralelo - Copaíba

TABELA 35 - Valores individuais de rigidez à compressão paralela às fibras - NBR 7190/97 - Copaíba.

TABELA 36 - Valores individuais de rigidez à compressão paralela às fibras - LOGSDON (1998) - Copaíba.

TABELA 37 - Parâmetros estatísticos para rigidez à compressão paralela - Copaíba.

TABELA 38 - Relação da resistência e da rigidez entre CP's preservados (CCA) e naturais (sem preservação) Copaíba

TABELA 39 - $\quad$ Parâmetros estatísticos da relação da resistência e da rigidez entre CP's preservados (CCA) e naturais (sem preservação) - Copaíba

TABELA 40 - Fator K - efeito do preservativo e do processo de tratamento nas propriedades mecânicas da madeira Copaíba. 
TABELA 41 - Resistência característica à compressão e ao cisalhamento paralelo - Jatobá.

TABELA 42 - Valores individuais de resistência à compressão e ao cisalhamento paralelo - Jatobá..

TABELA 43 - $\quad$ Parâmetros estatísticos para resistência à compressão paralela - Jatobá.

TABELA 44 - Parâmetros estatísticos para resistência ao cisalhamento paralelo - Jatobá.

TABELA 45 - Valores individuais de rigidez à compressão paralela às fibras - NBR 7190/97 - Jatobá.

TABELA 46 - Valores individuais de rigidez à compressão paralela às fibras - LOGSDON (1998) - Jatobá.

TABELA 47 - Parâmetros estatísticos para rigidez à compressão paralela - Jatobá.

TABELA 48 - Relação da resistência e da rigidez entre CP's preservados (CCA) e naturais (sem preservação) Jatobá.

TABELA 49 - Parâmetros estatísticos da relação da resistência e da rigidez entre CP's preservados (CCA) e naturais (sem preservação) - Jatobá.

TABELA 50 - Fator $\mathrm{K}$ - efeito do preservativo e do processo de tratamento nas propriedades mecânicas da madeira Jatobá.....

TABELA 51 - Resistência característica à compressão e ao cisalhamento paralelo (amostra 01) - Eucalipto Grandis..

TABELA 52 - Resistência característica à compressão e ao cisalhamento paralelo (amostra 02) - Eucalipto Grandis..

TABELA 53 - Valores individuais de resistência à compressão e ao cisalhamento paralelo (amostra 01) - Eucalipto Grandis..

TABELA 54 - Valores individuais de resistência à compressão e ao cisalhamento paralelo (amostra 02) - Eucalipto Grandis (correção da umidade segundo NBR 7190/97).

100

TABELA 55 - Valores individuais de resistência à compressão e ao cisalhamento paralelo (amostra 02) - Eucalipto Grandis (correção da umidade segundo LOGSDON (1998))........

TABELA 56 - Resistência à compressão paralela (amostra 01) Eucalipto Grandis.

TABELA 57 - $\quad$ Resistência ao cisalhamento paralelo (amostra 01) Eucalipto Grandis.

Resistência à compressão paralela (amostra 02) Eucalipto Grandis.

TABELA 58 Resistência ao cisalhamento paralelo (amostra 02) -

TABELA 59 Eucalipto Grandis.

TABELA 60 - Valores individuais de rigidez à compressão paralela (amostra 01) - Eucalipto Grandis...

TABELA 61 - Parâmetros estatísticos para a rigidez à compressão paralela (amostra 01) - Eucalipto Grandis. 
TABELA 62 - Valores indivuduais de rigidez à compressão paralela (amostra 02) - Eucalipto Grandis

TABELA 63 - Parâmetros estatísticos para a rigidez à compressão paralela (amostra 02) - Eucalipto Grandis.

TABELA 64 - Relação da resistência e da rigidez entre CP's preservados (CCA) e naturais (sem preservação) (amostra 01) - Eucalipto Grandis

TABELA 65 - Parâmetros estatísticos da relação da resistência e da rigidez entre CP's preservados (CCA) e os naturais (sem preservação) - (amostra 01 ) - Eucalipto Grandis....

TABELA 66 - Fator K - efeito do preservativo e do processo de tratamento nas propriedades mecânicas da madeira (amostra 01) - Eucalipto Grandis

TABELA 67 - Relação da resistência e da rigidez entre CP's preservados (CCA e CCB) e naturais (sem preservação) - (amostra 02) - Eucalipto Grandis

TABELA 68 - Parâmetros estatísticos da relação da resistência e da rigidez entre CP's preservados (CCA) e naturais (sem preservação) - (amostra 02) - Eucalipto Grandis.

TABELA 69 - Parâmetros estatísticos da relação da resistência e da rigidez entre CP's preservados (CCB) e naturais (sem preservação) - (amostra 02) - Eucalipto Grandis.

TABELA 70 - Fator K - efeito do preservativo (CCA) e do processo de tratamento nas propriedades mecânicas da madeira (amostra 02) - Eucalipto Grandis

TABELA 71 - Fator K - efeito do preservativo (CCB) e do processo de tratamento nas propriedades mecânicas da madeira (amostra 02) - Eucalipto Grandis

TABELA 72 - Resistência característica à compressão e ao cisalhamento paralelo (amostra 01 - PIN-01 a PIN-32)...

TABELA 73a - Resistência característica à compressão, à tração e ao cisalhamento paralelo (amostra 01a - PIN-01 a PIN-12) - (NBR 7190/97).

TABELA 73b - Resistência característica à compressão, à tração e ao cisalhamento paralelo (amostra 01a - PIN-01 a PIN-12) - (LOGSDON (1998)).

TABELA 74 - Resistência característica à compressão e ao cisalhamento paralelo (amostra 01b - PIN-13 a PIN-32).

TABELA 75 - Valores individuais de resistência à compressão e ao cisalhamento paralelo (amostra 01 - PIN-01 a PIN-32) correção da umidade (NBR 7190/97).

Valores individuais de resistência à compressão, ao cisalhamento e à tração paralela (amostra 01a - PIN-01 a PIN-12) - correção da umidade (NBR 7190/97). 
TABELA 77 - Valores individuais de resistência à compressão e ao cisalhamento paralelo (amostra 01b - PIN-13 a PIN-32) - correção da umidade (NBR 7190/97)

TABELA 78 - Resistência à compressão e ao cisalhamento paralelo (amostra 01 - PIN-01 a PIN-32) - correção da umidade (NBR 7190/97).

TABELA 79 - $\quad$ Resistência à compressão, ao cisalhamento e à tração paralela (amostra 01a - PIN-01 a PIN-12) - correção da umidade (NBR 7190/97)

TABELA 80 - Resistência à compressão e ao cisalhamento paralelo (amostra 01b - PIN-13 a PIN-32) - correção da umidade (NBR 7190/97).

TABELA 81 - Valores individuais de resistência à compressão e ao cisalhamento paralelo (amostra 01 - PIN-01 a PIN-32) correção da umidade (LOGSDON (1998)).

TABELA 82 - Valores individuais de resistência à compressão, ao cisalhamento e à tração paralela (amostra 01a - PIN-01 a PIN-12) - correção da umidade (LOGSDON (1998))......

TABELA 83 - Valores individuais de resistência à compressão e ao cisalhamento paralelo (amostra 01b - PIN-13 a PIN-32) - correção da umidade (LOGSDON (1998))

TABELA 84 - Resistência à compressão e ao cisalhamento paralelo (amostra 01- PIN-01 a PIN-32) - correção da umidade (LOGSDON (1998)).

TABELA 85 - Resistência à compressão, ao cisalhamento e à tração paralela (amostra 01 ${ }^{\mathrm{a}}$ - PIN-01 a PIN-12) - correção da umidade (LOGSDON (1998))

TABELA 86 - Resistência à compressão e ao cisalhamento paralelo (amostra 01b - PIN-13 a PIN-32) - correção da umidade (LOGSDON (1998)).

TABELA 87 - Valores individuais de rigidez à compressão paralela (amostra 01- PIN-01 a PIN-32) - correção da umidade (NBR 7190/97).

TABELA 88 - Valores individuais de rigidez à compressão paralela (amostra 01a - PIN-01 a PIN-12) - correção da umidade (NBR 7190/97).

TABELA 89 - Valores individuais de rigidez à compressão paralela (amostra 01b - PIN-13 a PIN-32) - correção da umidade (NBR 7190/97).

TABELA 90 - Valores individuais de rigidez à compressão paralela (amostra 01- PIN-01 a PIN-32) - correção da umidade (LOGSDON (1998)).

TABELA 91 - Valores individuais de rigidez à compressão paralela (amostra 01a - PIN-01 a PIN-12) - correção da umidade (LOGSDON (1998)). 
TABELA 92 - Valores individuais de rigidez à compressão paralela (amostra 01b - PIN-13 a PIN-32) - correção da umidade (LOGSDON (1998)).

TABELA 93 - Parâmetros estatísticos para a rigidez à compressão paralela - correção da umidade (NBR 7190/97)...............

TABELA 94 - Parâmetros estatísticos para a rigidez à compressão paralela - correção da umidade (LOGSDON (1998)).......

TABELA 95 - Relação da resistência e da rigidez entre CP's preservados e naturais - amostra 01 .

TABELA 96 - Relação da resistência e da rigidez entre CP's preservados e naturais - amostra 01a - (correção da umidade - NBR 7190/97).

TABELA 97 - Relação da resistência e da rigidez entre CP's preservados e naturais - amostra 01a (correção da umidade - LOGSDON (1998))

TABELA 98 - Relação da resistência e da rigidez entre CP's preservados e naturais - amostra 01b.

TABELA 99 - Parâmetros estatísticos da relação da resistência e da rigidez entre CP's preservados (CCA) e naturais (sem preservação) - amostra 01

TABELA 100 - Fator K - efeito do preservativo e do processo de tratamento nas propriedades mecânicas da madeira amostra 01

TABELA 101 - Parâmetros estatísticos da relação da resistência e da rigidez entre CP's preservados e naturais (sem preservação) - amostra 01a.

TABELA 102 - Fator K - efeito do preservativo e do processo de tratamento nas propriedades mecânicas da madeira amostra 01a.

TABELA 103 - Parâmetros estatísticos da relação da resistência e da rigidez entre CP's preservados (CCB) e naturais (sem preservação) - amostra 01 .

TABELA 104 - Fator K - efeito do preservativo e do processo de tratamento nas propriedades mecânicas da madeira amostra $01 b$

TABELA 105 - Fatores K - valores relativos ao efeito da penetração do preservativo CCA e do processo de tratamento espécies

TABELA 106 - Valores referentes às relações entre resistências características ao cisalhamento e à compressão paralela às fibras - espécies nativas

TABELA 107 - Fatores K - valores relativos ao efeito da penetração do preservativo CCA e do processo de tratamento, com correção da umidade recomendada pela NBR 7190/97 e sugerida por LOGSDON (1998) - Eucalipto Grandis. 
TABELA 108 - Fatores K - valores relativos ao efeito da penetração do preservativo $\mathrm{CCB}$ e do processo de tratamento, com correção da umidade recomendada pela NBR 7190/97 Eucalipto Grandis.

TABELA 109 - Fatores K - valores relativos ao efeito da penetração do preservativo CCA e do processo de tratamento, com correção da umidade sugerida por LOGSDON (1998) Eucalipto Grandis

TABELA 110 - Valores referentes às relações entre resistências características ao cisalhamento e à compressão paralela às fibras - Eucalipto Grandis.

TABELA 111 - Fatores K - valores relativos ao efeito da penetração do preservativo CCA e do processo de tratamento, com correção da umidade recomendada pela NBR 7190/97 Pinus Elliottii

TABELA 112 - Fatores K - valores relativos ao efeito da penetração do preservativo CCA e do processo de tratamento, com correção da umidade sugerida por LOGSDON (1998) Pinus Elliottii

TABELA 113 - Fatores K - valores relativos ao efeito da penetração do preservativo $\mathrm{CCB}$ e do processo de tratamento, com correção da umidade recomendada pela NBR 7190/97 Pinus Elliottii

TABELA 114 - Fatores K - valores relativos ao efeito da penetração do preservativo $\mathrm{CCB}$ e do processo de tratamento, com correção da umidade sugerida por LOGSDON (1998) Pinus Elliottii.....

TABELA 115 - Valores referentes às relações entre resistências características ao cisalhamento e à compressão paralela às fibras - Pinus Elliottii

TABELA 116 - Valores referentes às relações entre resistências características à compressão e à tração paralela às fibras - Pinus Elliottii. 


\title{
LISTA DE ABREVIATURAS E SIGLAS
}

\author{
ABNT - Associação Brasileira de Normas Técnicas \\ ACA - Arseniato de cobre amoniacal \\ ACC - Cromato de cobre ácido \\ AS - Australian Standard Specification \\ AWPA - American Wood Preserver's Association \\ AWPI - American Wood Preserver's Institute \\ BS - British Standard \\ CCA - Arseniato de cobre cromatado \\ CCB - Sais de cobre, cromo e boro \\ CSA - Canadian Standards Association \\ CZC - Cloreto de zinco cromatado \\ DIN - Deutsche International Norman \\ NBR - Norma Brasileira Registrada
}




\section{LISTA DE SÍMBOLOS}

\begin{tabular}{|c|c|}
\hline $\mathrm{CV}$ & - coeficiente de variação \\
\hline $\mathrm{E}_{\mathrm{c} 0, \mathrm{~m}}$ & $\begin{array}{l}\text { - módulo de elasticidade longitudinal médio à compressão paralela às } \\
\text { fibras, obtido através da média aritmética dos valores dos CP's "i”" }\end{array}$ \\
\hline $\mathrm{E}_{\mathrm{c} 0, \mathrm{nbr}}$ & $\begin{array}{l}\text { - módulo de elasticidade longitudinal à compressão paralela às fibras do } \\
\text { CP "i”, obtido através das recomendações da NBR 7190/97 }\end{array}$ \\
\hline $\mathrm{E}_{\mathrm{c} 0 \text {,regr }}$ & $\begin{array}{l}\text { - módulo de elasticidade longitudinal à compressão paralela às fibras do } \\
\text { CP "i", obtido através de regressão linear simples }\end{array}$ \\
\hline $\mathrm{f}_{\mathrm{c} 0, \mathrm{~m}}$ & $\begin{array}{l}\text { - resistência média à compressão paralela às fibras, obtida através da } \\
\text { média aritmética dos valores dos CP's "i } \mathrm{i} \text { " }\end{array}$ \\
\hline $\mathrm{f}_{\mathrm{c} 0, \mathrm{p}}$ & $\begin{array}{l}\text { - resistência à compressão paralela às fibras do CP “i” natural (sem } \\
\text { preservação) }\end{array}$ \\
\hline $\mathrm{f}_{\mathrm{c} 0, \mathrm{CCA}}$ & $\begin{array}{l}\text { - resistência à compressão paralela às fibras do CP "i" preservado com } \\
\text { CCA }\end{array}$ \\
\hline $\mathrm{f}_{\mathrm{c} 0, \mathrm{CCB}}$ & $\begin{array}{l}\text { - resistência à compressão paralela às fibras do } \mathrm{CP} \text { “i” preservado com } \\
\mathrm{CCB}\end{array}$ \\
\hline $\mathrm{f}_{\mathrm{t} 0, \mathrm{~m}}$ & $\begin{array}{l}\text { - resistência média à tração paralela às fibras, obtida através da média } \\
\text { aritmética dos valores dos CP's “i”" }\end{array}$ \\
\hline $\mathrm{f}_{\mathrm{t} 0, \mathrm{p}}$ & $\begin{array}{l}\text { - resistência à tração paralela às fibras do CP “i” natural (sem } \\
\text { preservação) }\end{array}$ \\
\hline $\mathrm{f}_{\mathrm{t} 0, \mathrm{CCA}}$ & - resistência à tração paralela às fibras do CP "i" preservado com CCA \\
\hline $\mathrm{f}_{\mathrm{t} 0, \mathrm{CCB}}$ & - resistência à tração paralela às fibras do $\mathrm{CP}$ "i”" preservado com CCB \\
\hline $\mathrm{f}_{\mathrm{v} 0, \mathrm{~m}}$ & $\begin{array}{l}\text { - resistência média ao cisalhamento paralelo às fibras, obtida através da } \\
\text { média aritmética dos valores dos CP's “i”" }\end{array}$ \\
\hline$f_{\mathrm{v} 0, \mathrm{p}}$ & $\begin{array}{l}\text { - resistência ao cisalhamento paralelo às fibras do } \mathrm{CP} \text { “i” natural (sem } \\
\text { preservação) }\end{array}$ \\
\hline $\mathrm{f}_{\mathrm{v} 0, \mathrm{CCA}}$ & $\begin{array}{l}\text { - resistência ao cisalhamento paralelo às fibras do CP "i” preservado } \\
\text { com CCA }\end{array}$ \\
\hline $\mathrm{f}_{\mathrm{v} 0, \mathrm{CCB}}$ & $\begin{array}{l}\text { - resistência ao cisalhamento paralelo às fibras do CP "i" preservado } \\
\text { com CCB }\end{array}$ \\
\hline $\mathrm{n}$ & - número de CP's da amostra \\
\hline $\mathrm{s}_{\mathrm{d}}$ & - desvio padrão da amostra \\
\hline $\mathrm{t}(95 \%)$ & $\begin{array}{l}\text { - coeficiente crítico da Distribuição de "t" de Student, para um valor de } \\
95 \% \text { de confiança }\end{array}$ \\
\hline$X_{\mathrm{m}}$ & - valor médio da amostra \\
\hline $\mathrm{X}_{125}$ & ência ou rigidez de um CP a $12 \%$ de umidade \\
\hline
\end{tabular}


$\mathrm{X}_{\mathrm{U} 5} \quad$ - resistência ou rigidez de um $\mathrm{CP}$ a $\mathrm{U} \%$ de umidade

$\mathrm{U}(\%) \quad$ - umidade do CP ensaiado

$\alpha \quad$ - fator de correção da umidade

$\mu_{\mathrm{x}} \quad$ - média dos desvios

$\rho_{12 \%} \quad$ - massa específica aparente de um CP a $12 \%$ de umidade 


\section{RESUMO}

PINHEIRO, R. V. (2001). Influência da preservação contra a demanda biológica nas propriedades de resistência e de elasticidade da madeira. São Carlos, 2001. 162p. Tese (Doutorado) - Escola de Engenharia de São Carlos, Universidade de São Paulo.

A madeira por ser renovável, de fácil obtenção e custo competitivo, tornou-se com o decorrer do tempo, um dos materiais pioneiros na construção civil. Porém, no Brasil, o emprego indiscriminado e descontrolado ao longo dos anos, principalmente na construção civil, proporcionou uma redução drástica das florestas nativas das regiões Sul/Sudeste. Consequentemente, passou a ser necessária a utilização de madeiras alternativas e, entre elas, pode-se citar as espécies dos gêneros Eucalytpus e Pinus. Sabendo-se que tais espécies são altamente susceptíveis à demanda biológica, é indispensável a adoção de medidas preventivas visando melhorar a sua durabilidade. Dentre algumas medidas possíveis, a preservação através da introdução de produtos químicos por processos industriais é a mais eficaz. Uma das questões levantadas a respeito do citado procedimento reporta à sua influência no comportamento intrínsico da madeira, no tocante às suas propriedades mecânicas. Portanto, a partir daí, este projeto tem o objetivo de verificar a influência da preservação química (processo e produto) sob vácuo-pressão contra a demanda biológica, através de preservativos hidrossolúveis (tipo $\mathrm{CCA}$ e $\mathrm{CCB}$ ), nas propriedades de resistência e de elasticidade das espécies de Eucalipto Grandis (Eucalyptus grandis) e Pinus Elliottii (Pinus elliottii). Usando apenas o produto 
CCA, também foi verificada a influência em quatro espécies nativas: Angelim (Vatairea sp), Ipê (Tabebuia sp), Copaíba (Copaifera sp) e Jatobá (Hymenaea sp).

Como sub-produto da pesquisa, foram obtidas algumas relações entre os valores da resistência característica à compressão e ao cisalhamento paralelo às fibras, bem como entre os valores da resistência característica à compressão e à tração paralela às fibras. Também foi objeto de estudo, em uma fase preliminar, a análise da possível variação, ao longo do comprimento da peça, da propriedade de resistência e de rigidez (elasticidade) à compressão paralela às fibras, uma vez mantida fixa a posição nos raios.

No final, foram obtidos alguns resultados relevantes para a relação entre os valores de compressão paralela da madeira sem preservação e a tratada quimicamente, principalmente referente ao Pinus Elliottii. Nesta espécie, para o tratamento realizado com CCA, o acréscimo foi de 17\% (retenção em torno de 10 $\mathrm{kg} / \mathrm{m}^{3}$ ), enquanto o produto $\mathrm{CCB}$ (retenção em torno de $40 \mathrm{~kg} / \mathrm{m}^{3}$ ) levou a um aumento de 55\% em média. Outros resultados passíveis de comentários, referem-se às relações entre propriedades características de cisalhamento e compressão (preservados e sem preservação) para todas as espécies estudadas. De maneira geral, os valores foram bem superiores àqueles estabelecidos pela NBR 7190/97, alcançando patamares em torno de 50\% para as espécies de reflorestamento e $90 \%$ para as espécies nativas (exceto para o Ipê).

De forma sucinta, pode-se concluir que a preservação química industrial é de extrema relevância, principalmente por não reduzir e, em alguns casos até aumentar os valores das propriedades mecânicas estudadas, além de ser um método comprovado e eficaz contra a biodeterioração

Palavras-chaves: madeira; preservação; propriedades mecânicas. 


\begin{abstract}
PINHEIRO, R. V. Influence of the preservation against the biological demand in strength and stiffness properties of wood. São Carlos, 2001. 162p. Tese (Doutorado) - Escola de Engenharia de São Carlos, Universidade de São Paulo.
\end{abstract}

As time goes bye, wood had been one of the main materials in building construction, because it's renovation, easy obtainment ans competitive cost. In Brazil, indiscriminate employing during last decades, particularly in South and Southwest regions, reduced drastically the native species offer. The use of alternative species, as those from Pinus and Eucalyptus genera, became necessary. As the cited species are so susceptible to biological demand, to take prevent procedures to increase natural durability in indispensable. Among these procedures, chemical preservation under pressure in industrial plans can be considered very efficient. One of the questions related to chemical preservation is its influence in mechanical behavior of treated wood. So, the aim of the work is to determine the influence of chemical preservation under pressure (with preservative substances as CCA and $\mathrm{CCB}$ ) in strength and stiffness properties of Eucalipto Grandis (Eucalyptus grandis) and Pinus Elliottii (Pinus elliottii). The influence do CCA preservative was studied to four tropical essences: Angelim (Vatairea $s p$ ), Ipê (Tabebuia $s p$ ), Copaíba (Copaifera $s p$ ) and Jatobá (Hymenaea $s p$ ). At least, comparative values of mechanical properties of natural and preserved wood are presented.

Keywords: wood; preservation; mechanical properties. 


\section{CAPÍTULO 1: INTRODUÇÃo}

\subsection{Generalidades}

A madeira é um material orgânico, natural e celular, de origem vegetal, com características químicas e físico-mecânicas que a tornam apta a uma grande diversidade de uso. Trata-se de matéria-prima de formação contínua em quaisquer partes do planeta, seja em florestas nativas ou em florestas artificiais oriundas de reflorestamentos.

Este material foi um dos primeiros a ser utilizado pelo homem para satisfazer suas necessidades básicas, por exemplo, na confecção de armas e dos mais variados utensílios. Posteriormente, o homem procurou desenvolver, para si mesmo e para sua família, ambiente para protegê-los das intempéries e permitir o desenvolvimento das atividades com maior segurança. A partir daí, surgiram as primeiras edificações, sendo possível associar a evolução do ser humano ao processo evolutivo de sua moradia.

Da história, a seqüência natural do desenvolvimento das habitações deu-se, em princípio, com os materiais até então disponíveis, ou seja, a pedra, a argila e a madeira.

Inicialmente, a partir da composição entre pedra e argila, dava-se origem às moradias, enquanto a madeira era empregada como material de defesa, isto é, compunha as estruturas paliçadas. A seguir, a madeira, em conjunto com as folhas de palmeiras, compunha as ocas, cabanas indígenas nas tribos das regiões tropicais.

O transcorrer da história trouxe consigo a inovação de materiais e ferramentas, possibilitando os novos processos construtivos, tais como a construção de elementos de vedação a partir da combinação argila/madeira (pau-a-pique) e, a seguir, de paredes de madeira. Mais recentemente, foram empregadas paredes com tijolos de barro cru e tijolos de argila cozida. Além dos usos já mencionados, a 
madeira também contribuiu na construção de embarcações, bem como em utensílios domésticos.

Atualmente, tal material é de grande utilização nas indústrias moveleira e de transporte (construção naval, fabricação de vagões de trens e em carrocerias de automóveis), bem como na fabricação de ferramentas, de papel, de lápis, de material esportivo, de instrumentos musicais e de embalagens (caixotes, paletes, entre outros). Além disto, emprega-se também nas indústrias de chapas de fibras, de chapas de compensadas e de chapas aglomeradas.

Na construção civil se verifica com grande freqüência o emprego da madeira, em esquadrias - portas, janelas, caixilhos, divisórias; elementos de vedação e revestimento - lambris, painéis, tacos, tábuas para assoalhos; elementos estruturais coberturas, pontes, passarelas, viadutos, formas e cimbramentos, estacas, dormentes, postes de eletrificação, cruzetas, silos, currais, galpões, cercas, etc.

Hoje, em muitos países da Europa, da Ásia, da América (principalmente Estados Unidos e Canadá) e da Oceania, a madeira tem sido intensivamente empregada. Como exemplo marcante, citam-se dois países de culturas totalmente distintas, porém ambos aplicam a madeira em larga escala em suas construções. Tais países, Estados Unidos e Japão, têm aproximadamente $85 \%$ e 95\% das suas residências executadas em madeira, respectivamente, BENEVENTE (1995).

Todavia, mesmo sendo o Brasil uma nação detentora de vastas áreas florestadas do planeta, o uso da madeira na construção civil ainda não incorporou todos os avanços tecnológicos já alcançados. A maneira inadequada do uso da madeira e o restrito conhecimento dos métodos que prolongam sua vida útil conduzem à redução da durabilidade e reforçam alguns preconceitos sobre a qualidade e o desempenho do material.

A madeira, dada sua natureza, está sujeita à ação de agentes degradadores, principalmente de origem biológica, entre eles os fungos, os cupins e as brocas. Muitas espécies, particularmente as provenientes de áreas de reflorestamento, produzem madeira susceptível à demanda biológica, seja como árvores vivas, cortadas (toras), desdobradas (serradas) ou em serviço. Vale ressaltar que a susceptibilidade da madeira está diretamente relacionada à quantidade de nutrientes e extrativos. Portanto, para que tal material tenha durabilidade significativa, medidas 
devem ser adotadas, desde a fase de desdobro até as disposições construtivas adequadas, passando pelos processos de secagem, preservação, classificação, condições de armazenamento e processamento.

Desnecessário se faz mencionar, mas a preservação química é reconhecidamente a medida mais eficaz, não apenas para aumentar a durabilidade da madeira, mas também para proporcionar às espécies com relevantes propriedades de resistência e/ou elasticidade, porém susceptíveis à demanda biológica, a oportunidade de utilização estrutural. Deste modo, justifica-se o pequeno acréscimo inicial de investimento, com a gradual redução do custo de recuperação e reposição de materiais.

Tomando como ponto de partida a conveniência e a necessidade da preservação, por parte de algumas espécies, tem-se na impregnação de produtos químicos, através dos métodos industriais (aplicação sob condições de vácuo/pressão) e não-industrial (aplicação sem vácuo/pressão), a atividade mais utilizada para promover o aumento da vida útil da estrutura. $O$ principal questionamento deste procedimento diz respeito à manutenção da integridade das propriedades de resistência e de elasticidade.

Portanto, tal assunto é o objeto de discussão deste trabalho, com vistas à geração de informações que possam dar suporte técnico ao dimensionamento de elementos estruturais de madeira.

\subsection{Objetivos}

As atividades de pesquisa contidas neste projeto têm como objetivo principal verificar a influência da preservação química (processo e produto) sob vácuo-pressão contra a demanda biológica, através dos preservativos hidrossolúveis comercializados (CCA e CCB), nas propriedades mecânicas das madeiras originárias das matas nativas e das florestas artificiais oriundas de reflorestamento. Como subproduto da pesquisa, foram obtidas algumas relações entre os valores da resistência característica à compressão e ao cisalhamento paralelo às fibras, bem como entre os valores da resistência característica à compressão e à tração paralela às fibras.

Também foi objeto de estudo, em uma fase preliminar, a análise da possível variação, ao longo do comprimento da peça, da propriedade de resistência e de 
rigidez (elasticidade) à compressão paralela às fibras, uma vez mantida fixa a posição nos raios.

Em resumo, neste estudo foi dado ênfase à compressão paralela às fibras (resistência e rigidez), à tração e ao cisalhamento paralelo às fibras (resistência), pois estas são fundamentais para o projeto de estruturas de madeira.

\subsection{Justificativas}

Com os estudos realizados no decorrer dos anos, observou-se que o emprego estrutural da madeira no Brasil não tem se verificado de modo plenamente conveniente e consequentemente, há desperdício do material. Este fato proporcionou uma redução drástica das florestas nativas das regiões Sul/Sudeste, tidas como grandes centros consumidores do país. Assim sendo, houve a necessidade da importação de madeira de outras regiões. Entretanto, aspectos técnicos e econômicos relacionados com a exploração e transporte fazem com que o custo se eleve, tornando a utilização das mesmas cada vez menor.

Diante destas dificuldades, utilizam-se as florestas artificiais, principalmente aquelas de Eucaliptos e Pinus, como fonte alternativa para obtenção de madeiras destinadas às mais diversas finalidades, tais como madeira serrada, papel e celulose, madeira reconstituída e outras. Gradativamente, pode-se observar o crescimento e a aceitação do emprego estrutural das peças de madeira provenientes das áreas de reflorestamento, principalmente em fôrmas e cimbramentos, pontes em zonas rurais, passarelas, postes de eletrificação rural, estruturas de cobertura, etc.

Sabendo-se da realidade em que envolve o ambiente das estruturas de madeira (projeto e sistema construtivo), pode-se classificá-los como insipientes, baseando-se na pequena importância ainda atribuída à elaboração de projetos de estruturas e na pouca qualificação da mão-de-obra. Estes fatores, juntamente com a elevada susceptibilidade à demanda biológica por parte de algumas espécies, são de extrema relevância para a redução da vida útil das estruturas e, consequentemente, primordiais para a não valorização do material em questão.

Com o intuito de contribuir positivamente com o quadro mencionado acima, PINHEIRO \& ROCCO LAHR (1996) puderam comprovar a viabilidade técnica, da utilização em estruturas, de espécies tropicais alternativas e de espécies de 
reflorestamento. Entre elas, são aqui mencionadas: Quarubarana ou Cambará (Erisma uncinatum), Canafístula (Cassia ferruginea), Cupiúba (Goupia glabra), Eucalipto Citriodora (Eucalyptus citriodora), Eucalipto Grandis (Eucalyptus grandis), Pinus Elliottii (Pinus elliottii) e Pinus Taeda (Pinus taeda). As demais espécies, como a Peroba-rosa (Aspidosperma polyneurum), Sucupira (Diplotropis spp), Tatajuba (Bagassa guianensis), Jatobá (Hymenaea sp), Maçaranduba (Manilkara sp), Angelim (Hymenolobium sp), entre outras, não foram citadas devido à sua comprovada aplicação. Porém, o emprego estrutural de tais espécies, com base nas propriedades físicas, de resistência e de elasticidade, não é suficiente para garantir um elevado tempo de vida útil às estruturas. Por isso, deve-se considerar a durabilidade natural das mesmas e analisar quão susceptíveis aos ataques de agentes biodegradadores são estas espécies.

Atualmente, para a obtenção de quaisquer produtos, sejam eles estruturais ou não, tem-se dado prioridade à sua qualidade e ao seu custo final. Tais fatores, qualidade e custo, ganham importância em conseqüência das exigências do rigoroso mercado consumidor. Portanto, são necessários investimentos em pesquisas enfatizando tópicos que possam vir a influenciar as propriedades intrínsecas do material e aperfeiçoar a elaboração de projetos. Como resposta, seriam produzidas estruturas de madeira menos onerosas, com durabilidade comprovada e sem comprometimento da segurança dos usuários.

Após estudo da literatura disponível, verificou-se a necessidade de uma abordagem mais ampla com relação a alguns assuntos. Entre eles, ficou evidenciada a relevância de estudos referentes à influência da preservação química nas propriedades de resistência e de elasticidade da madeira, já que a necessidade da utilização de espécies de reflorestamento em estruturas torna-se cada vez mais evidente. $\mathrm{O}$ desenvolvimento da pesquisa ocorreu com base nas propriedades de compressão, de tração e de cisalhamento paralelo às fibras, consideradas essenciais para a elaboração de projetos estruturais.

Desta forma, o contexto da proposta de pesquisa em questão objetivou a obtenção de informações, para evidenciar a viabilidade técnica do tratamento preservativo e, num futuro próximo pudessem contribuir efetivamente para um emprego mais nobre e racional das madeiras, principalmente na construção de 
estruturas. A viabilidade da preservação das espécies das florestas artificiais é também justificada através da relação custo/benefício referentes a implantação, a exploração e a possibilidade de manejo sustentado. 


\section{CAPÍTULO 2: REVISÃo BIBLIOGRÁFICA}

Neste capítulo são registradas as referências bibliográficas contidas em livros, teses de doutorado, dissertações de mestrado e artigos técnicos que, de alguma maneira, relacionam-se com o trabalho proposto.

\subsection{Recursos florestais brasileiros}

As árvores, do ponto de vista botânico, são vegetais superiores, de elevada complexidade anatômica e fisiológica. São classificadas de acordo com a $13^{\underline{a}}$ divisão da "Classificação de Engler", as Fanerógamas. Esta classificação se subdivide em Gimnospermas e Angiospermas. Na subdivisão das Gimnospermas, a classe das Coníferas é a mais importante e, na literatura, é designada por "madeiras moles" ou "softwoods". As Angiospermas se subdividem em Monocotiledôneas e Dicotiledôneas, sendo estas conhecidas por folhosas, "madeiras duras" ou "hard woods". Cabe observar que as espécies pertencentes a este compõem as chamadas "matas nativas".

\subsubsection{Aspectos gerais referentes às matas nativas}

$\mathrm{Na}$ década de 1980, a cobertura florestal nativa estava presente em aproximadamente $51 \%$ do território nacional. Deste total, as matas nativas representadas pelas florestas Amazônica e Atlântica, ocupavam em torno de 70\% (300 milhões de hectares), SOCIEDADE BRASILEIRA DE SILVICULTURA apud BENEVENTE (1995) ${ }^{1}$.

${ }^{1}$ SOCIEDADE BRASILEIRA DE SILVICULTURA. A sociedade brasileira e seu patrimônio florestal. São Paulo: SBS, 1987. apud BENEVENTE, V.A. Durabilidade em construções de madeira - uma questão de projeto. São Carlos, 1995. 231p. Dissertação (Mestrado) Escola de Engenharia de São Carlos - Universidade de São Paulo. 
A Floresta Amazônica representa $20 \%$ das florestais tropicais do planeta e está contida no território conhecido por Amazônia Legal, incluindo os Estados do Amazonas, Pará, Rondônia, Mato Grosso, Acre, Roraima, Goiás, Tocantins e parte do Maranhão. Por sua vez, a Floresta Atlântica se distribuía em quase todo o litoral brasileiro, ocupando áreas desde o Estado do Rio Grande do Sul até o Rio Grande do Norte. Esta floresta continha espécies semelhantes às da Floresta Amazônica, mas, atualmente, estão exauridas devido à ocupação agropecuária e à exploração madeireira descontrolada, MONTANA QUÍMICA (1991).

Vale lembrar que são poucos os registros referentes as matas nativas, mas, MAINIERI \& CHIMELO publicaram, em 1989, um trabalho intitulado "Fichas de Características das Madeiras Brasileiras”, cujo objetivo foi registrar as características físico-mecânicas, anatômicas, de durabilidade natural, de capacidade de preservação e de aplicações para algumas espécies nativas brasileiras.

\subsubsection{Descrição resumida das espécies nativas utilizadas}

\section{a) Angelim (Vatairea sp)}

Ocorre na sua maioria em matas pluviais costeiras, desde a o sul do Estado da Bahia, passando pelo norte dos Estados do Espírito Santo e Rio de Janeiro, até o Estado de São Paulo. Também são encontradas no Estado de Minas Gerais e nas fronteiras da Floresta Amazônica. Nestas regiões são conhecidas vulgarmente por Angelim-araroba e Angelim-amargoso. Este gênero apresentou elevada resistência aos ataques de organismos xilófagos, principalmente aos cupins de madeira seca e fungos. Demonstrou ter baixa permeabilidade aos produtos preservantes quando submetida a tratamento sob vácuo-pressão. A resistência mecânica é considerada de média a alta, sendo recomendada para o emprego em vigas, caibros, portas e janelas, carrocerias, dormentes, vagões, tacos, postes, estacas, mourões, cabos de ferramentas, tábuas para soalhos, entre outras, MAINIERI \& CHIMELO (1989). 


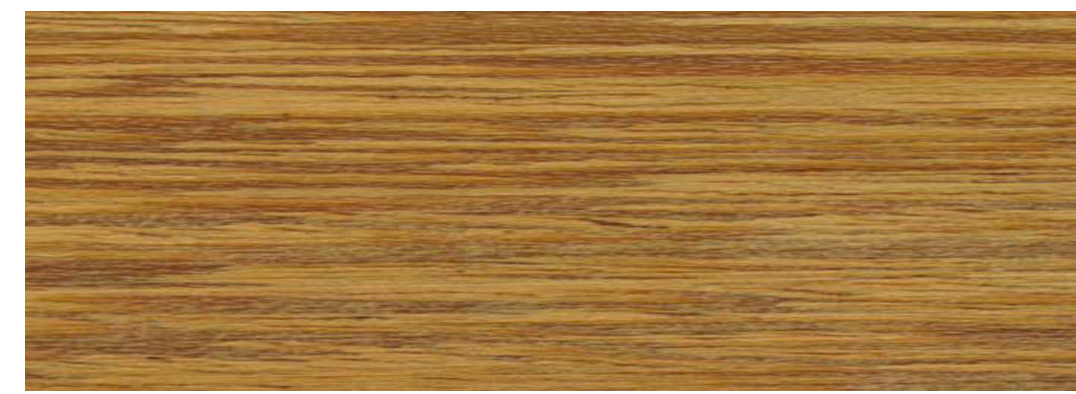

FIGURA 01 - Corte longitudinal - Angelim (Vatairea sp)

\section{b) Garapa (Apuleia leiocarpa)}

Segundo RIZZINI (1978) e MAINIERI \& CHIMELO (1989), o gênero Apuleia ocorre em todas as matas brasileiras, desde a Amazônia até o Rio Grande do Sul. Algumas variedades destas espécies são freqüentemente encontradas a partir do centro do Estado da Bahia até o extremo norte do país, principalmente no Estado do Pará. Na região Norte recebem os nomes de Muirajuba, Barajuba, Muiratauá, etc, enquanto no Nordeste são denominadas por Amarelão, Jitaí e Jutaí. Outras variedades, por sua vez, são encontradas desde o sul do Estado da Bahia, em matas litorâneas, até o Estado do Rio Grande do Sul, incluindo os Estados do Paraná e Santa Catarina. São vulgarmente denominadas por Amarelinho, Gema-de-ovo, Grápia, Jataí-amarelo, Garapa-amarela, Garapa-branca, entre outros. Também é encontrada nos Estados de Mato Grosso, Mato Grosso do Sul, Goiás, Rondônia, bem como em algumas regiões do Uruguai, Paraguai e Argentina. Tal espécie apresenta resistência moderada ao apodrecimento, alta susceptibilidade ao ataque de cupins de madeira seca e demonstrou ter baixa permeabilidade aos produtos preservantes quando submetida a tratamento sob vácuo-pressão. A resistência mecânica é considerada de média a alta, sendo recomendada para o emprego em vigas, caibros, portas e janelas, carrocerias, dormentes, postes, estacas, mourões, cabos de ferramentas, tábuas em geral, entre outras. 


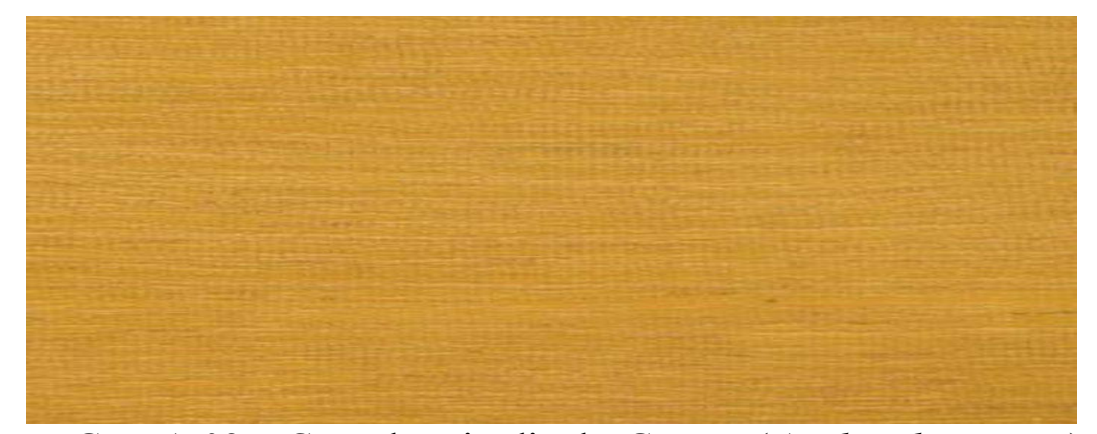

FIGURA 02 - Corte longitudinal - Garapa (Apuleia leiocarpa)

\section{c) Ipê (Tabebuia sp)}

Conforme RIZZINI (1978) e MAINIERI \& CHIMELO (1989), o gênero Tabebuia é encontrado desde o Estado do Ceará até o Estado do Paraná, incluindo os Estados de São Paulo e Minas Gerais. Estas espécies possuem uma característica própria, ou seja, contém os poros obstruídos por uma resina chamada ipeína, de cor amarela-esverdeada. Tais espécies recebem diversos nomes, conforme a região do país. Por exemplo, da Amazônia até o sul do Estado da Bahia, recebe o nome de Paud'arco, enquanto dos Estados do Rio de Janeiro e Minas Gerais até o Rio Grande do Sul, são conhecidas por Ipê, Ipê-amarelo, Ipê-roxo, Ipê-preto, Ipê-uma, entre outros. Em outras regiões, tais como sul dos Estados de Mato Grosso e Goiás, são denominadas de Piúna, Piúna-amarela, Piúna-roxa, etc. Este gênero também é encontrado em toda América Latina, desde o México até a Argentina. Tais espécies apresentam alta resistência ao ataque de organismos xilófagos, principalmente aos cupins e fungos. Em contrapartida, a durabilidade natural referentes às brocas marinhas pode ser considerada baixa. São altamente impermeáveis aos produtos preservantes quando submetida a tratamento sob vácuo-pressão. Em função da elevada resistência mecânica são recomendadas para o emprego estrutural, como vigas, caibros, vagões, dormentes, degraus de escada, defensas, cruzetas, implementos agrícolas, carrocerias, tábuas em geral, etc. 


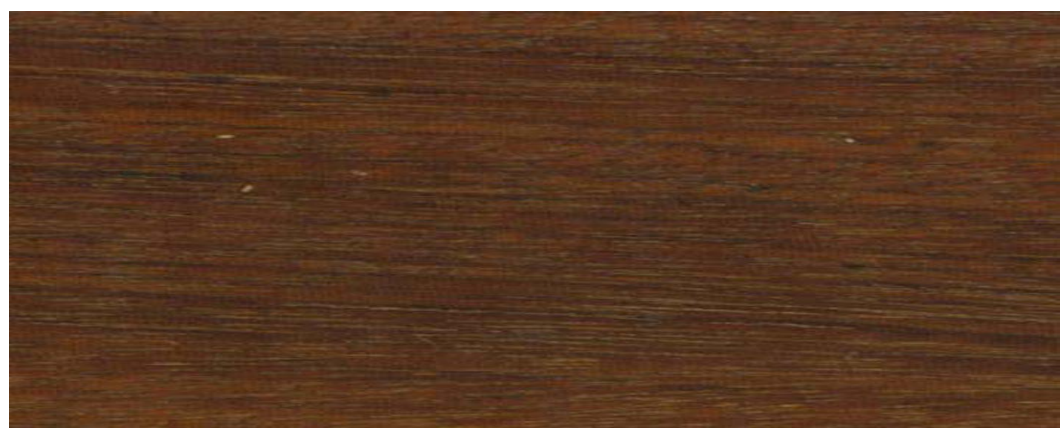

FIGURA 03 - Corte longitudinal - Ipê (Tabebuia sp)

\section{d) Jatobá (Hymenaea sp)}

De acordo com RIZZINI (1978) e MAINIERI \& CHIMELO (1989), o gênero Hymenaea é encontrado em todo o país, seja em matas secas como em matas pluviais. Na Amazônia recebe os nomes de Jutaí, Jutaí-açu, Jutaí-mirim, Jutaívermelho, etc, enquanto do Estado do Piauí até o Paraná, além de ser conhecida por Jatobá, também é denominada por Jataí, Jataíba, Farinheira, Burandã, entre outras. Este gênero também é encontrado desde o México até a Bolívia e Paraguai. No comércio internacional recebe os nomes de Courbaril e Locust-tree. Conforme os mesmos autores, a espécie em questão apresenta resistência mecânica elevada, resistência natural variando de média a alta e pouco permeável aos produtos preservantes quando submetida a tratamento sob vácuo-pressão. Tais espécies são recomendadas para o emprego em vigas, caibros, portas e janelas, implementos agrícolas, carrocerias, vagões, dormentes, cruzetas, tábuas em geral, entre outras.

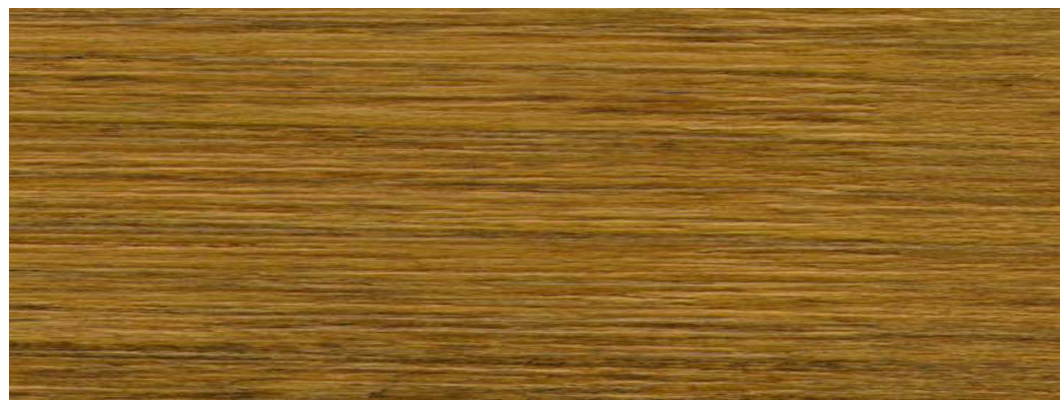

FIGURA 04 - Corte longitudinal - Jatobá (Hymenaea sp)

\section{e) Pau-amarelo (Euxylophora paraensis)}

Segundo RIZZINI (1978), tal espécie é típica das matas do Estado do Pará, especialmente abundante nas margens da rodovia Belém-Brasília. Nesta região é 
também conhecida por Pau-cetim, Amarelo-cetim, Limão-rana, Pequiá-cetim, etc. Esta madeira é indicada para acabamentos internos, tacos, lambris e móveis.

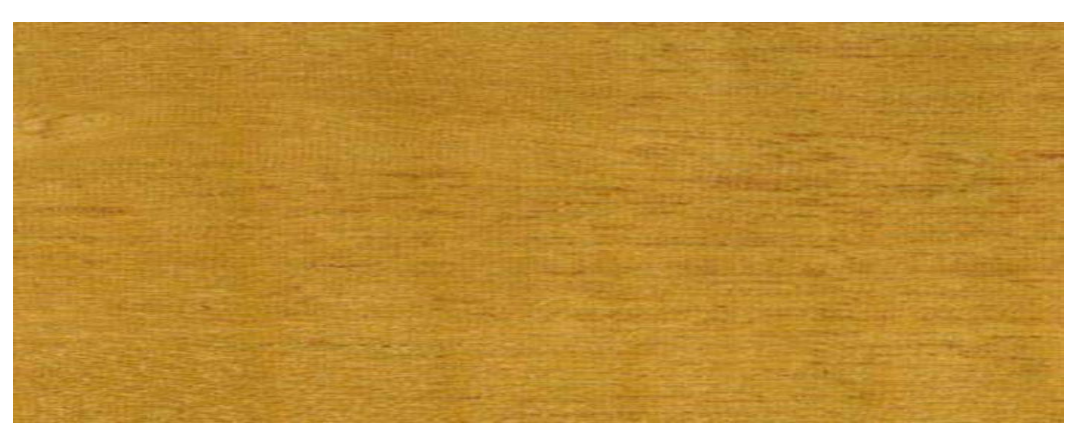

FIGURA 05 - Corte longitudinal - Pau-amarelo (Euxylophora paraensis)

\section{f) Copaíba (Copaifera sp)}

Segundo RIZZINI (1978) e MAINIERI \& CHIMELO (1989), o gênero Copaifera ocorre em quase todas as matas brasileiras, enquanto as espécies langsdorffii e trapezifolia são tipicamente da mata atlântica, principalmente do sul do Estado da Bahia até o sul de Santa Catarina. Nestas regiões também são denominadas por Copaúva, Óleo-de-copaíba. Na Amazônia é comum encontrar as espécies duckei, multijuga, martii e reticulata. Estas espécies são conhecidas por Copaíba-marimari, Copaíba-preta, Copaíba-vermelha, entre outras. De acordo com os mesmos autores, a espécie em questão apresenta resistência mecânica moderada e elevada durabilidade natural. As espécies da Família Leguminosae, geralmente encontradas no norte do país, demonstraram ser permeáveis aos produtos preservantes quando submetida a tratamento sob vácuo-pressão. Em contrapartida, as espécies da Família Caesalpiniaceae, típicas do Sudeste, apresentam baixa permeabilidade. Conforme as características mencionadas, recomenda-se o emprego na construção civil, mais especificamente em vigas, caibros, portas e janelas, implementos agrícolas, carrocerias, tábuas em geral, entre outras.

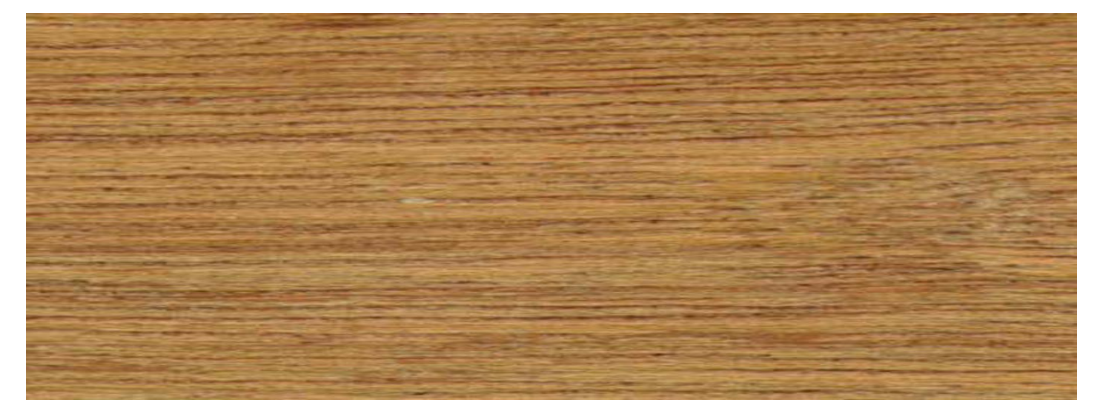

FIGURA 06 - Corte longitudinal - Copaíba (Copaifera $s p$ ) 
Os CP's usados para o desenvolvimento deste trabalho são oriundos dos Estados de Mato Grosso (Angelim,, Copaíba, Jatobá e Pau-amarelo) e de Rondônia (Garapa e Ipê).

\subsubsection{Aspectos gerais referentes às matas de reflorestamento}

De acordo com MONTANA QUÍMICA (1991), o pioneirismo das matas de reflorestamento ocorreu com o objetivo de recuperar os mananciais do Morro da Tijuca, no Rio de Janeiro, em 1861, enquanto para finalidade econômica, se deu no início deste século, através do estudioso Edmundo Navarro de Andrade. A ênfase nas matas artificiais no Brasil se fixou nos gêneros Pinus e Eucalipto, por terem melhor aclimatação e maior aceitação comercial.

O gênero Pinus, classe das Coníferas, provavelmente teve sua origem no norte da Eurásia ou no norte da América, há cerca 250 milhões de anos. A partir daí, o gênero vem se dispersando, descendo pelos continentes europeu e asiático, bem como pelo americano, chegando até a América Central e Caribe, onde se formou um centro secundário de evolução, do qual surgiram as incursões para a América do Sul, BORTOLETTO Jr. (1993).

Informações interessantes a respeito da introdução de espécies exóticas no país encontram-se reunidas no trabalho "Introdução de Coníferas no Brasil: Um Esboço Histórico", PEREIRA (1987) O autor reúne os dados das primeiras introduções de coníferas feitas no Brasil, em princípio, para fins ornamentais e, em seguida, com finalidades silviculturais. Posteriormente, foram destinadas para suprir a redução de oferta de matéria-prima causada pelo intenso extrativismo nas reservas de Araucária angustifolia, o Pinho-do-Paraná, única fonte no país de "madeira mole" e fibra longa, e para reduzir a dependência nacional de importação de celulose e resina, produtos obtidos a partir das coníferas.

No Brasil, a introdução de espécies exóticas de coníferas, principalmente do gênero Pinus, deu-se na década de 40 e no início dos anos 50. BORTOLETTO Jr. (1993) destaca e separa a participação do setor privado e do setor público no processo de introdução de coníferas para fins silviculturais no Brasil, relatando sua importância e a alternância de seu período de atuação até o advento da lei $n^{0} 5106$, de 1966, a respeito de incentivos fiscais para reflorestamento. A partir desse período, a 
iniciativa privada passa a preponderar sobre a do governo, e os reflorestamentos ganham impulso expressivo, alcançando ainda na mesma década 6,2 milhões de hectares, sendo mais da metade em Eucalipto e cerca de 30\% com Pinus.

Segundo informação divulgada pela SOCIEDADE BRASILEIRA DE SILVICULTURA (SBS-2000), as matas que produzem a madeira de Pinus correspondem 1,9 milhão ha, ou seja, aproximadamente $0,6 \%$ da área de floresta nacional.

Segundo BERTOLANI (1978), os Pinus tropicais, tais como o Pinus oocarpa e algumas variedades do Pinus caribaea (caribaea, bahamensis e hondurensis), necessitam de temperatura média ao redor de $23^{\circ} \mathrm{C}$, com invernos secos e deficiências hídricas. Em contrapartida, os subtropicais, como o Pinus Elliottii e Pinus Taeda, podem ser plantados na maior parte do Estado de São Paulo, cujo clima abrange invernos frios, chuvas bem distribuídas ao longo do ano e altitude entre 600 e 1100 metros. Os Pinus, de um modo geral, não necessitam de solos férteis, desenvolvendo-se bem em solos ácidos e com pouca matéria orgânica. Preferem solos arenosos e profundos, próprios dos cerrados e dos campos.

De acordo com ANDRADE (1961), o gênero Eucalyptus, do grupo das Dicotiledôneas, é originário da Austrália e foi introduzido no Brasil a partir de 1850. No início do presente século, por volta de 1904, plantações racionalizadas foram se multiplicando, em função da necessidade da Companhia Paulista de Estrada de Ferro em substituir as espécies nativas do Estado de São Paulo no fornecimento de madeira para a produção de lenha, imprescindível às locomotivas a vapor. Em razão do intenso trabalho de Edmundo Navarro de Andrade, eminente estudioso do assunto, tornaram-se muito populares algumas das 144 espécies de eucalipto introduzidas, tais como: Eucalipto Grandis (Eucalyptus grandis), Eucalipto Saligna (Eucalyptus saligna), Eucalipto Robusta (Eucalyptus robusta), Eucalipto Tereticornis (Eucalyptus tereticornis), Eucalipto Maculata (Eucalyptus maculata), Eucalipto Paniculata (Eucalyptus paniculata), Eucalipto Punctata (Eucalyptus punctata), Eucalipto Citriodora (Eucalyptus citriodora), Eucalipto Globulus (Eucalyptus globulus).

Tal popularidade se justificou pelos resultados altamente satisfatórios de plantios conduzidos em solos fracos, sem interesse para a agricultura. Com o advento 
das máquinas de tração elétrica, o eucalipto passou a ser utilizado na produção industrial de chapas de fibra, na fabricação de celulose e papel, bem como na fabricação de chapas de madeira aglomerada. Para estas finalidades se destacaram as espécies saligna, robusta e grandis, consagrando a conveniência do plantio de eucaliptos para atendimento da crescente demanda industrial. Atualmente, o Eucalipto grandis também está sendo empregado estruturalmente na forma de madeira serrada, devido ao melhor comportamento no que diz respeito às tensões internas. Concomitantemente ao interesse industrial, as ferrovias passaram a empregar a madeira de eucalipto na confecção de dormentes, enquanto as empresas de distribuição de energia elétrica a utilizavam sob a forma de postes, visando à expansão de suas redes. Nestas circunstâncias, ganharam destaque as espécies: citriodora, tereticornis, maculata, paniculata e punctata. Tais espécies possuem propriedades físico-mecânicas condizentes ao emprego estrutural, além de ter um crescimento satisfatoriamente rápido, podendo ser obtidos postes com alta densidade com idade ao redor de vinte e cinco anos.

Atualmente, as matas que produzem a madeira de Eucalipto correspondem a 3 milhões de hectares, isto é, 1,0\% da área de floresta nacional, conforme informação da SOCIEDADE BRASILEIRA DE SILVICULTURA (SBS-2000).

\subsubsection{Descrição resumida das espécies de reflorestamento utilizadas}

\section{a) Pinus (Pinus spp)}

No território nacional existem algumas espécies e, dentre elas destacam-se o Pinus caribaea (var. caribaea, bahamensis e hondurensis) e Pinus oocarpa, espécies tropicais; Pinus taeda e Pinus elliottii, espécies sub-tropicais.

Segundo GOLFARI et al. (1978), o Pinus caribaea var. caribaea é nativo da província de Pinar del Rio e Ilha de Pinus, Cuba, enquanto a variedade bahamensis ocorre nas Ilhas Bahamas. O Pinus caribaea var. hondurensis ocorre naturalmente na costa atlântica da América Central, de Belize até Nicarágua. De acordo com CARPANEZZI et al. (1986), estas variedades podem ser empregadas em construções leves e pesadas, construção de barcos, fabricação de laminados, chapas de fibras, de partículas e para a produção de celulose de fibras longas, entre outros usos. 
Adicionalmente, estas variedades são produtoras de resina. A massa específica aparente da citada espécie, independentemente da variedade, é de 0,35 a $0,50 \mathrm{~g} / \mathrm{cm}^{3}$.

A espécie oocarpa tem área de ocorrência desde o norte do México até o norte da Nicarágua, GOLFARI et al. (1978). De acordo com BERTOLANI (1978), a forma de crescimento da espécie gera madeira de maior massa específica aparente ( $12 \%$ de umidade), variando entre 0,45 e $0,60 \mathrm{~g} / \mathrm{cm}^{3}$, podendo atingir no final de uma rotação de 30-35 anos, padrões de qualidade semelhantes ao de Araucária angustifolia. Segundo o mesmo autor, a espécie é altamente resistente ao fogo. A madeira desta espécie pode ser utilizada para construções leves, fabricação de chapas compensadas, de fibras, de partículas e para produção de celulose de fibras longas. A espécie não é considerada boa produtora de resina, CARPANEZZI et al. (1986).

Pinus taeda é natural das regiões Leste e Sudeste dos Estados Unidos e tem uma área de ocorrência extensa e descontínua. Com massa específica aparente entre 0,47 e $0,51 \mathrm{~g} / \mathrm{cm}^{3}$, a madeira é usada em construções leves, na fabricação de chapas compensadas, de fibras, de partículas e para produção de celulose de fibras longas. A espécie não é boa produtora de resina, CARPANEZZI et al. (1986).

As espécies elliottii são originárias do Sudoeste dos Estados Unidos e sua massa específica aparente $\left(12 \%\right.$ de umidade) varia entre 0,50 e $0,56 \mathrm{~g} / \mathrm{cm}^{3} . \mathrm{Em}$ idades mais avançadas, esta espécie tem a mesma utilidade da anterior, porém é considerada excelente para produção de resina, CARPANEZZI et al. (1986).

No Estado de São Paulo tais espécies encontram-se cultivadas nas regiões de Itirapina, Ibaté, Casa Branca, Agudos, Manduri, Águas de Santa Bárbara, Sorocaba e Itapetininga. Também existe cultivo nas regiões entre o sul do Estado do Paraná e o Rio Grande do Sul. Das espécies mencionadas, todas são susceptíveis aos ataques de fungos e cupins, possuem alta permeabilidade aos produtos preservativos quando submetidas a tratamento sob vácuo-pressão e moderada resistência mecânica. 


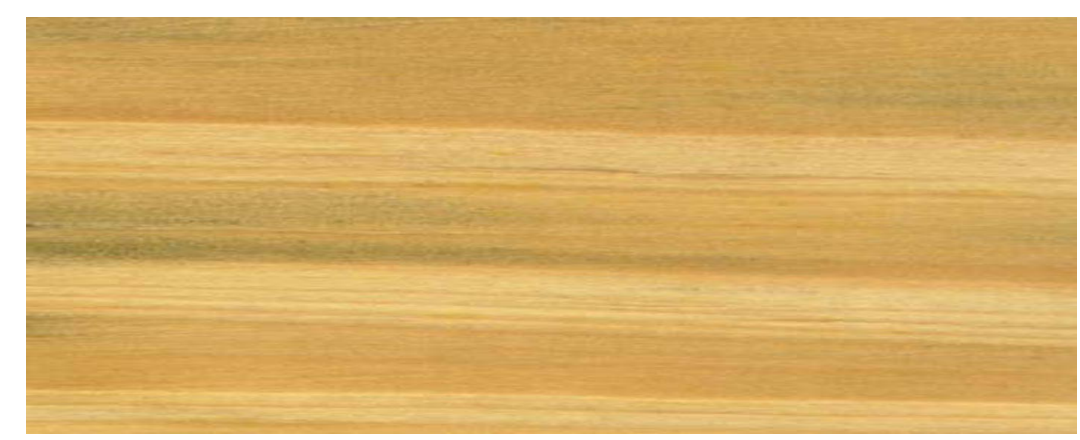

FIGURA 07 - Corte longitudinal - Pinus (Pinus spp)

\section{b) Eucalipto Grandis (Eucalyptus grandis)}

No Brasil existem dezenove espécies que cobrem todas as necessidades das áreas cultivadas e, dentre elas, o Eucalyptus grandis. No Estado de São Paulo tal espécie é plantada nas regiões de Rio Claro, Jundiaí, Franca, Guatapará, Camaquã, Itirapina, São Simão. Do mesmo modo, existe cultivo nos Estados do Paraná, Santa Catarina, Rio Grande do Sul, Mato Grosso, Mato Grosso do Sul e Minas Gerais. Destacam-se também as regiões de plantio localizadas no Sul da Bahia e Estado do Espírito Santo.

No que diz respeito às características gerais da madeira de Eucalipto grandis, pode-se registrar a elevada susceptibilidade aos ataques de fungos e cupins. A permeabilidade aos produtos preservativos, quando submetida ao tratamento em auto-claves, é elevada na região periférica do tronco (alburno), enquanto o cerne (região interna) é praticamente impregnável. As propriedades mecânicas (resistência e rigidez) são consideradas de média a boa.

Com base nestas propriedades, o Eucalipto Grandis tem sido utilizado na produção industrial de chapas de fibra, na fabricação de celulose e papel, bem como na fabricação de chapas de madeira aglomerada, além de se constituir em uma excelente alternativa para produção de elementos estruturais de madeira laminadacolada, graças ao seu bom comportamento sob a forma de madeira serrada. 


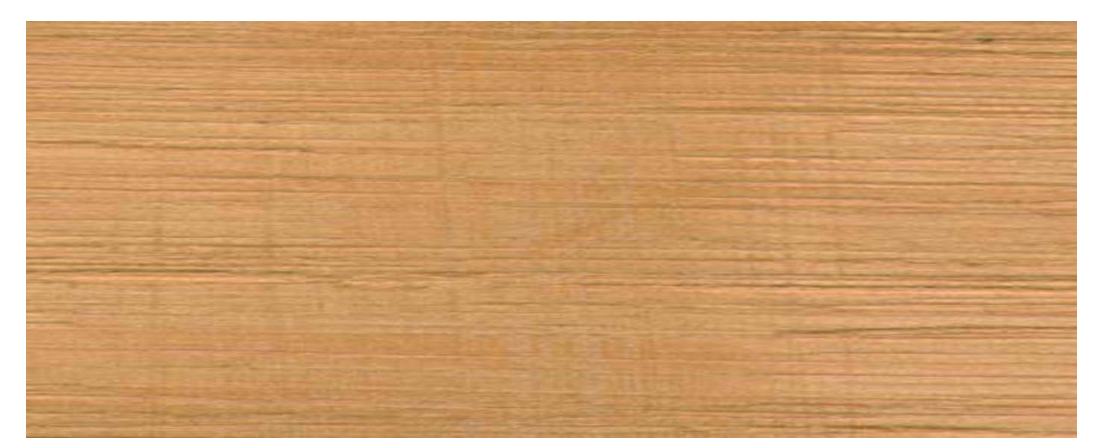

FIGURA 08 - Corte longitudinal - Eucalipto Grandis (Eucalyptus grandis)

A madeira de Pinus utilizada para o desenvolvimento deste trabalho é oriunda do município de Itirapina, Estado de São Paulo. As peças de Eucalipto teve origem dos municípios de Itirapina e Rio Claro, ambos situados no Estado de São Paulo.

\subsection{Madeira: material de construção}

Segundo a DIVISÃO DE MADEIRAS/IPT (1985), provavelmente por volta de 6000 a.C., foi inventado o machado de pedra e, a partir desta data, tem-se como marco do início da utilização da madeira.

De acordo com ROCCO LAHR (1983), por volta do ano 3000 a.C., os egípcios já usavam a madeira em estruturas treliçadas, fazendo a sustentação das palafitas às margens do Rio Nilo. Além disto, usavam as pedras como elementos de fundação e a argila como parede, na função de vedar. Com o passar do tempo, a madeira - na forma de troncos - começa a ser utilizada em cobertura de edificações. Este processo foi difundido por volta de 1000 a.C. na Mesopotâmia. Na Pérsia, no século VII a.C., desenvolveram-se estruturas de coberturas planas, mas o grande obstáculo a ser vencido era a falta de ferramentas adequadas para facilitar o corte da madeira.

No oriente, entre o ano 1000 a.C. e 500 a.C, a Arquitetura Indiana usufruía das coberturas no formato de abóbadas e arcos, bem como na forma piramidal ou tronco de pirâmide. Na China, o emprego da madeira em estruturas de cobertura sempre foi mais comum, com formato de retângulos superpostos. A geometria das estruturas japonesas era bem mais simples em comparação às utilizadas pelos chineses. 
A arquitetura grega se baseou em técnicas mais desenvolvidas, usando seções transversais sobrepostas, unidas através de travessas (cavilhas), quando sentida a ineficiência de apenas um tronco para suportar vãos maiores.

Foi na Arquitetura Romana que surgiram as seções compostas dos banzos superior e inferior e, entre eles se encaixavam as diagonais e os montantes. Ainda com os Romanos, e a partir do século IV d.C. com os Bizantinos, foram construídas treliças com aspectos geométricos muito parecidos com as atuais. Nesse período prevalecia ainda o uso de telhados de duas águas, para residências, igrejas, edifícios públicos, palácios e outros.

Com o passar dos séculos, fins do século X d.C., a Arquitetura Muçulmana se fez notar pelas novas características de coberturas, características estas adaptadas às condições do clima. As coberturas das edificações eram feitas através de pranchas justapostas apoiadas em vigas de madeira, com uma capa de material isolante e impermeabilizante, e finalmente com um revestimento de placas cerâmicas. Em torno do século XV d.C., a Arquitetura Romana reviveu os telhados com duas águas, largamente utilizados pelos Bizantinos, mas, também, introduziu os telhados de uma água, com aplicação em igrejas.

A Arquitetura Gótica foi marcada pela utilização das grandes treliças de madeira, caracterizadas pelas acentuadas inclinações dos panos, o que acarretava problemas nas ligações, que eram feitas por cavilhas e encaixes. Pela ausência de tecnologia dos dispositivos de ligações, estava impossibilitada a construção de estruturas de madeira com mais de 25 metros de vão. Somente na transição entre os séculos XVI e XVII apareceram os parafusos e as chapas metálicas.

Apesar da grande incidência de estruturas de madeira até as primeiras décadas do século XIX, pouco se conhecia a respeito das características físicas, de resistência e de elasticidade da madeira. Além disso, havia apenas aplicações baseadas nas obras anteriores. Portanto, não eram comuns os projetos estruturais mais elaborados.

A partir do início do século XX, deu-se a evolução dos processos de cálculo por parte de alguns estudiosos, tornando o emprego da madeira mais diversificada e racional. 
Como exemplo prático desta evolução, pode ser citado o engenheiro civil austríaco Erwin Hauff que, em 20 de setembro de 1929 fundou a firma HAUFF, cuja finalidade principal foi a de elaborar projetos e construir estruturas de madeira treliçada e cavilhada, principalmente no Estado de São Paulo. Esta atividade foi interrompida com o seu falecimento em 02 de agosto de 1960, CÉSAR (1991).

Outra alternativa não convencional foi proposta pelos americanos no final da década de 50, isto é, estruturas pré-fabricadas de madeira, cujas ligações eram executadas através de cobrejuntas metálicas BARROS Jr. (1991).Tal assunto também foi abordado por UJVARI (1983), BARALDI (1996), entre outros.

Atualmente, a madeira continua sendo muito empregada como estruturas treliçadas para coberturas destinadas a residências, barracões industriais e comerciais, depósitos, instalações sócio-esportivas e em edificações rurais. Dentre as inúmeras possibilidades, pode-se afirmar que tais estruturas foram as primeiras a serem utilizadas com a finalidade específica de sustentação de telhados. Entretanto, verifica-se que outros sistemas estruturais alternativos, como arcos, pórticos e "shed" têm emprego menos freqüente.

Ao longo do desenvolvimento histórico, foi constatado que a madeira, por ser um recurso natural, sempre esteve presente no cotidiano do ser humano. A diversidade de suas características (elevada resistência mecânica em relação à massa, facilidade de usinagem, boa resistência química, propriedades térmicas e elétricas satisfatórias, além de apreciáveis propriedades organolépticas, tais como cheiro, texturas e colorações) possibilita o seu emprego para as mais distintas finalidades, tais como estruturas (pontes, cimbramentos, coberturas, silos), móveis, brinquedos, pisos e lambris, instrumentos musicais, embalagens, implementos agrícolas e divisórias. Todavia, a tecnologia da utilização da madeira atinge os mais variados níveis de desenvolvimento, tendo como bom exemplo as indústrias de chapas (fibras, aglomeradas e compensadas). Em contrapartida, há enormes deficiências nos setores relacionados com a construção civil, principalmente no que diz respeito à utilização da madeira como elemento estrutural. Tal fato esta diretamente relacionado à diminuição da durabilidade natural de certas espécies, devido à alguns fenômenos físicos, químicos e biológicos.

\subsection{Preservação de madeira}


Um engenheiro projetista, que usa a madeira como material estrutural, espera dela algumas qualidades de fundamental importância, como durabilidade natural e manutenção das propriedades físico-mecânicas com o decorrer do uso.

Em decorrência do extrativismo descontrolado e sem planejamento, COCKCROFT \& HENNINGSSON (1983) comentam que, de acordo com os órgãos competentes americanos, em torno do ano 2020 as florestas tropicais acessíveis dos países sub-desenvolvidos tenham sido cortadas. Segundo TAVARES (1984), em um panorama geral, estima-se que 4000 metros quadrados de florestas tropicais desaparecem por minuto. Tal fato deixa evidente que algumas medidas devem ser tomadas com urgência, entre elas, o reflorestamento com manejo sustentado. Em 1994/95, FLORESTAR ESTATÍSTICO, de acordo com as afirmações anteriores, registra que, nos grandes centros consumidores do Brasil (regiões Sul/Sudeste) vem ocorrendo decréscimo acentuado de espécies de madeira de boa durabilidade natural. Este fato propicia a imigração de espécies nativas de outras regiões do país, principalmente regiões Norte e Centro-Oeste. Em conseqüência, eleva-se o custo, devido às dificuldades de exploração e transporte. Todavia, as regiões consumidoras já possuem áreas reflorestadas, principalmente espécies dos gêneros Pinus e Eucalyptus, em condições de fornecer madeira para as aplicações necessárias. É de conhecimento de todos os pesquisadores da área, que tais espécies são altamente susceptíveis a ataques de organismos xilófagos, necessitando de alguns cuidados que previnam a demanda biológica, tais como a época e idade do corte, método de secagem e de preservação, classificação, condições dos locais de armazenamento e disposições construtivas. Dentre estas, a bibliografia destaca a preservação química como sendo o método mais eficaz contra a deterioração da madeira. Como exemplo da eficácia deste método, HARTFORD (1976/80) estimou que nos Estados Unidos, no período de 1909 a 1974, houve uma economia de quatro bilhões de árvores destinadas à produção de postes.

Sobre a abordagem referente à preservação química, LEPAGE (1986) faz a seguinte comentário: “A despeito de certo sensacionalismo que a mídia nacional e internacional vem emprestando à temática, felizmente os órgãos a quem compete a legislação e regulamentação do uso dos pesticidas, mercê do esforço da comunidade técnica que atua no ramo, vêm abrindo exceções para a indústria de preservação de 
madeiras por terem sido convencidos: a) do caráter localizado deste tipo de poluição, circunscrito à área de influência das usinas e portanto da possibilidade de um controle efetivo; b) do grau de fixação dos modernos preservativos que torna reduzido o risco de contaminação dos efluentes por lixiviação dos ingredientes ativos que entram na sua composição."

\subsubsection{Tipos de preservação}

Os tratamentos preservativos têm como objetivo principal proteger quaisquer peças de madeira contra possíveis ações deterioradoras, sejam elas oriundas de fenômenos naturais (bióticos ou abióticos) ou de fenômenos físico-químicos. Atualmente, a preservação não pode ser considerada como custo adicional, mas um investimento indispensável que traz benefícios, por exemplo, proporcionando à madeira condições de durabilidade para competir no mercado consumidor com os demais materiais de construção e, consequentemente poderá gerar maior economia na utilização dos recursos florestais. Além disto, também incentiva o emprego do material.

Segundo MONTANA QUÍMICA (1991), entre outros, para prevenir a proliferação de organismos xilófagos, pode-se adotar algumas técnicas de preservação de madeiras, como a preservação natural, indireta, biológica e química.

A preservação natural corresponde a um conjunto de medidas que auxiliam na redução ou eliminação da ação dos organismos xilófagos. Dentre as medidas, citam-se a época e a idade do corte da árvore, a secagem e o armazenamento da madeira, as condições climáticas do local da obra e os detalhes construtivos.

A técnica de preservação indireta, também conhecida como "tratamento de solo", é empregada para prevenção ou controle de ataques por cupins de solo, evitando o acesso destes organismos xilófagos às peças de madeira em serviço.

Quanto à preservação biológica, trata-se de um processo de inserção de fungos não xilófagos na peça de madeira já contaminada, com o objetivo de combater os fungos xilófagos.

O último método, a preservação química, é a mais conhecida e usada no campo da tecnologia da madeira, e direciona-se principalmente ao combate das ações dos agentes biodeterioradores. Esta técnica de preservação pode ser entendida como 
sendo a incorporação de produtos químicos no interior de quaisquer peças de madeira, com a finalidade de retardar ou prevenir o ataque de organismos xilófagos. Este tratamento serve como obstáculo tóxico à fonte de alimentos dos fungos, provocando o envenenamento dos nutrientes celulares e prevenindo a deterioração ou evitando que ela se alastre.

Segundo TAYLOR (1974) e COCKCROFT (1977), pode-se definir quatro categorias quanto à necessidade de preservação das peças de madeira:

a) $1^{\underline{a}}$ Categoria (preservação essencial) - os elementos de madeira devem ser necessariamente preservados quando a madeira estiver exposta continuamente a ambientes agressivos sem a possibilidade de emprego de disposições construtivas ou por exigência dos códigos de obra e a experiência apontar risco de ruína da estrutura devida ao ataque de agentes biodegradadores. Como exemplo, pode-se citar: zona de afloramento entre o solo e os pilares, estruturas em contato com água doce ou marinha, regiões de elevada infestação de cupins subterrâneos, etc.

b) $2^{\underline{a}}$ Categoria (preservação desejável) - esta preservação deve ocorrer quando existe elevado risco de infestação e grande dificuldade de manutenção ou tratamento curativo. Tal situação poderá acontecer em peças de madeira sem proteção exposta a altos índices pluviométricos ou em ambientes submetidos à contínua umidade (áreas de serviço, banheiros e cozinhas).

c) $3^{\underline{a}}$ Categoria (preservação opcional) - neste caso, a preservação poderá ser facultativa, isto é, quando a situação apresenta pequeno risco de ataques por organismos xilófagos ou a manutenção e o tratamento curativo são de baixo grau de dificuldade.

d) $4^{\underline{a}}$ Categoria (preservação desnecessária) - considera-se desnecessária a preservação nas seguintes situações: madeira com elevada durabilidade natural, condições de serviço que não expõem os elementos de madeira a risco e quando os detalhes construtivos zelam pela integridade total da madeira.

Com base na literatura consultada, será enfatizado o método de preservação por meio da utilização de produtos químicos através dos tratamentos preventivo e curativo.

\subsubsection{Tratamento preventivo}


O objetivo principal do tratamento preventivo é preservar peças de madeira antes da sua infestação, prevenindo a deterioração das mesmas em serviço. Atualmente, os métodos preventivos mais utilizados para tratamento de peças de madeira através da preservação química podem ser divididos em Pré-tratamento, Processo Caseiro (sem vácuo/pressão) e em Processos Industriais (com vácuo/pressão).

\subsection{Pré-tratamento}

A madeira, antes de ser posta em serviço, ou seja, durante o intervalo de tempo entre o corte e a comercialização, também deve ser protegida contra a demanda biológica, evitando assim a sua degradação e, consequentemente, a desvalorização. Neste período, seja na forma de tora ou de madeira desdobrada, a proteção se faz necessária, devido ao alto teor de umidade da mesma.

Para as toras, principalmente em regiões tropicais, algumas medidas podem ser adotadas, por exemplo, a imersão em água, o jateamento superficial de produtos químicos diluídos em água, além da vedação de suas extremidades.

Para a proteção das peças processadas, seja na forma de madeira serrada ou postes, pode-se empregar a secagem artificial através de estufas convencionais ou de alta temperatura. Em algumas regiões do país, com elevadas temperaturas ao longo do ano, adota-se também a secagem natural, ou seja, através da exposição da madeira à energia solar. Durante o período compreendido entre tal secagem e a comercialização, faz-se uma preservação provisória por meio de produtos químicos diluídos, com função inseticida e fungicida. 


\subsection{Processo não-industrial ou sem vácuo/pressão}

Nestes processos a preservação ocorre sem que haja aplicação de pressão na superfície do elemento de madeira e, por isso, a impregnação, através dos produtos químicos, atinge apenas regiões periféricas.

De acordo com RICHARDSON (1978), DEUS instruiu Noé para que fizesse a impermeabilização do casco de madeira de sua arca com piche, provavelmente visando a proteção contra água.

Em 3500 a.C., os fenícios e cartagineses também utilizavam piche como elemento de impermeabilização na proteção dos cascos de suas embarcações. Nesta mesma época, com a mesma finalidade, os gregos aplicavam cera, alcatrão e chapas de chumbo, ANON (1952) apud HENRIQUES DE JESUS ${ }^{1}$.

Segundo HENRIQUES DE JESUS (1987), a civilização egípcia, reconhecida pela técnica usada em embalsamentos, mesmo desconhecendo os agentes causadores do apodrecimento, já sabia que a madeira com baixo teor de umidade não apodreceria. Desta forma, em torno de 2500 a 2000 anos a.C., protegiam a madeira através da utilização de óleos de origem animal, vegetal e mineral. Na mesma época, também houve tentativas de preservação através da queima superficial da madeira.

Outras civilizações antigas, como as de Burna, China, Grécia, Itália, em torno de 1000 a 500 anos a.C., aproveitando os conceitos até então usados pelos egípcios, posicionavam os pilares sobre base de pedra para mantê-los mais afastados da umidade. Além disto, abriam furos e aplicavam óleos com o intuito de preservá-los por mais tempo, GRAHAM (1973) e WILKINSON (1979). Conforme RICHARDSON (1978), Alexandre - O Grande (356-323 a.C.) aplicava óleo vegetal (oliva) no madeiramento das pontes com intuito de protegê-las contra o apodrecimento. Segundo o mesmo autor, Vasco da Gama (1469-1524) e seus contemporâneos portugueses usavam o método de carbonização dos cascos das embarcações, procurando preservá-los.

\footnotetext{
1 ANON. The history of the preservation of fouling. In: MARINE FOULING AND IT'S PRESERVATION, Annapolis, United States Naval Institute, 1952. Annapolis, p.211-223. apud JESUS, J.M.J. Secagem ao ar livre e secagem solar de madeiras aplicadas na construção civil. São Carlos, 152p. Dissertação (Mestrado) - Escola de Engenharia de São Carlos, Universidade de São Paulo.
} 
Por volta de 250 a.C., as embarcações dos romanos, também eram protegidas por chapas de metais, com o intuito de proteger contra a deterioração oriunda das brocas marinhas, bem como evitar o rompimento dos cascos devido aos choques entre embarcações durante as batalhas. Em resumo, até o final do século XV e início do século XVI, todos os procedimentos empregados para a preservação da madeira eram empíricos.

Somente com a intensificação das viagens marítimas ocorridas entre o final do século XV e o século XVIII, é que notaram-se os imensos prejuízos causados às embarcações marinhas e, a partir daí houve incentivos ao desenvolvimento de produtos preservativos mais eficazes.

Em 1657, Johann Glauber, químico alemão, foi o pioneiro no desenvolvimento de um trabalho científico, propondo um processo que consistia na carbonização da madeira, seguida da pintura com creosoto e, posteriormente, imersão em uma solução de ácido pirolenhoso, WILKINSON (1979). O mesmo autor registrou que Chapmam, engenheiro civil inglês, estimou, em 1817, uma duração média de sete a dez anos para as embarcações britânicas preservadas através de óleos, colas, resinas, borracha, alcatrão, creosoto, entre outros produtos disponíveis na época.

Em 1831, Kyan patenteou um método preservativo, conhecido por Kyanização. Neste método, imergia-se as peças de madeira em um tanque aberto, sujeito à pressão atmosférica, contendo solução de cloreto de mercúrio. Este processo foi usado para preservar dormentes, principalmente no sul da Alemanha.

Segundo pesquisadores como HUNT \& GARRATT (1962), KARLSEN (1967), KOLLMANN (1968), GRAHAM (1973), RICHARDSON (1978), WILKINSON (1979), e LEPAGE et al. (1986), vários outros procedimentos para tratamento de madeiras recém-cortadas foram propostos, destacando-se o Processo de Substituição de Seiva ou Processo de Boucherie, inventado por Auguste Boucherie e patenteado em 1838. O preservativo empregado era o sulfato de cobre.

De acordo com HUNT \& GARRATT (1962) e WILKINSON (1979), em 1867, Seely inventou e patenteou o método de impregnação química denominado Banho Quente-Frio. Tal método obteve grande aceitação comercial, devido à simplicidade dos equipamentos utilizados, bem como à sua eficiência. Este 
procedimento, apesar de não envolver pressão em autoclaves, ainda é muito empregado, principalmente para preservar espécies de madeira com baixo teor de umidade.

Atualmente, os processos caseiros de preservação mais comuns são: pincelamento ou pulverização, imersão rápida ou prolongada, banho quente-frio, difusão, capilaridade ou substituição de seiva ou processo de Boucherie.

CAVALCANTE (1982), LEPAGE et al. (1986) e MONTANA QUÍMICA (1991) apresentam detalhadamente cada um dos processos citados acima. Segundo GALVÃO (1976), dentre os processos mencionados os mais viáveis são os de substituição de seiva e banho quente-frio. O mesmo autor relata resumidamente cada processo e cita a proporção adequada de produtos químicos para cada caso.

Entre os processos de impregnação sem pressão, o único que oferece alguma importância industrial no Brasil é o banho quente-frio, RAIMBAULT (1983). Classicamente, este processo só é aplicado com preservativos oleossolúveis.

Tal método apresenta algumas vantagens consideráveis, como a execução em qualquer local sem a necessidade de mão-de-obra especializada, a não exigência de equipamentos sofisticados e, além de tudo, é menos oneroso. Por isso, é muito apropriado para pequenos e médios proprietários rurais.

\subsection{Processo industrial ou à vácuo/pressão}

Os processos industriais de preservação são aqueles onde a introdução do preservativo na madeira ocorre de maneira forçada, através da aplicação de pressão na superfície do elemento, podendo atingir todo o lenho (caso das coníferas) ou todo o alburno (caso das dicotiledôneas).

De acordo com RICHARDSON (1978) e WILKINSON (1979), este método de preservação começou a surgir no início do século XIX, em 1831, quando Breant patenteou um processo realizado em autoclaves. Tal método consistia de um vácuo inicial, cujo objetivo era retirar o ar contido no lúmem, e da aplicação do preservativo sob pressão.

Conforme a literatura consultada, foi em 1838, com John Bethell, o marco inicial da preservação através de processo industrial, utilizando-se o creosoto como produto preservativo. Tal método consistia de três etapas: vácuo inicial, período de 
pressão e, finalmente, outro período de vácuo. Como resultado, o lúmem e a parede celular recebiam preservativo, por isso, o processo foi batizado por Full cell ou Célula cheia. Por motivos óbvios, este método também recebeu o nome de Processo de Bethell. Outro processo muito reconhecido foi proposto por Burnett, em 1847. Assim como o processo anterior, Burnett introduzia o preservativo nos elementos de madeira através de pressões dadas em autoclaves. A vantagem e o grande responsável pelo sucesso deste processo foi a utilização do cloreto de zinco, preservativo disponível a baixo custo na época.

A elevada retenção de preservativo dado pelo Processo de Bethell, muitas vezes tornava-o oneroso, convertendo-se assim no principal limitante para o seu uso. Conforme YAMAMOTO (1974), tal fato incentivou a invenção de um tratamento mais econômico. Surgiu então o processo, tido como Célula Vazia, dado por Wasserman, em 1902. Porém, como o referido método foi colocado em prática por Rüeping, recebeu o nome de Processo de Rüeping, KOLLMANN (1968), GRAHAM (1973), RICHARDSON (1978), WILKINSON (1979), CAVALCANTE (1982) e LEPAGE et al. (1986). Os mesmos autores registram que, em 1906, Lowry propôs um método usando uma quantidade menor de equipamentos. A principal diferença entre os processos de Rüeping e Lowry é que o primeiro aplica uma injeção de ar comprimido antes da solução preservativa. Ao término do tratamento, ambos os métodos têm por princípios básicos deixar apenas as paredes celulares impregnadas, reduzindo a quantidade de preservativo a ser utilizada.

Observa-se que, até o início do século XX, todos os principais processos de tratamento preservativo por meio de produtos químicos já tinham sido inventados. Portanto, a partir daí, os aperfeiçoamentos foram conseguidos, sempre baseados nos processos já existentes.

Segundo LEPAGE et al. (1986), atualmente, os processos convencionais de impregnação a vácuo/pressão são os seguintes:

a) Processo da Célula Cheia (Full cell process): Processo de Bethell, de Burnett, de Boulton, de Cellon e Dow.

b) Processo da Célula Vazia (Empty cell process): Processo Rüeping e de Lowry. 
Os mesmos autores citam outros processos de tratamento preventivo menos empregados, tais como: de alta pressão, de duplo vácuo, OPM (Oscilant Pression Method), MSU (Mississipi State University), com jato de alta energia e $Q$.

Conforme a unanimidade verificada na literatura consultada, dentre os tratamentos sob vácuo/pressão, os mais empregados são os Processos de Bethell, de Rüeping e de Lowry, sendo o primeiro o mais importante.

É válido ressaltar que, para quaisquer tipos de processos empregados, a preservação deve ser feita considerando a espécie a ser tratada, as dimensões da peça, bem como a retenção e penetração desejada.

Conforme CAVALCANTE (1982), RAIMBAULT (1983) e LEPAGE et al. (1986), os processos industriais mais eficientes, têm como base os seguintes fatores: tratar grandes quantidades de madeira em curto intervalo de tempo; tratamento mais eficiente devido a uma distribuição mais uniforme; melhor controle de qualidade do tempo de aplicação, na retenção e penetração do preservativo na madeira.

Como limitações, mencionam-se o custo dos equipamentos e de sua manutenção, mão-de-obra mais especializada e o transporte até a usina de tratamento.

De modo a comprovar a eficiência do tratamento preservativo via processos industriais, o químico industrial e supervisor técnico do departamento de preservação e tratamento de madeiras da Sayerlack, J. A. Campos, em entrevista cedida à Revista Téchne nov/dez - 1995, № 19 , afirma que: "o processo em autoclave permite garantir por vinte e cinco anos madeiras que não durariam mais que três anos sem tratamento".

Quanto aos métodos de preservação, é inegável a superioridade dos processos de impregnação com pressão, principalmente se houver comparação em termos de qualidade e eficácia do tratamento.

\subsubsection{Tratamento curativo}

Estas medidas serão aplicadas quando a infestação já estiver instalada. De acordo com LEPAGE et al. (1986) e MONTANA QUÍMICA (1991), os processos de tratamento curativo podem se dar da seguinte maneira: fumigação ou expurgo, aspersão, injeção, tratamento do solo e métodos de pasta e bandagem. 
Os mesmos autores descrevem com detalhes os processos de tratamento curativos mencionados acima.

\subsubsection{Classificação dos preservativos químicos}

Com base na unanimidade da literatura, os preservativos destinados à proteção de peças estruturais podem ser classificados em três categorias, ou seja, hidrossolúveis, oleossolúveis e oleosos. MONTANA QUÍMICA (1991) reúne estas categorias em dois grupos, tomando o solvente como referência, isto é, oleossolúveis e oleosos (óleo) e hidrossolúveis (água).

O preservativo oleoso mais comum é o creosoto, enquanto o oleossolúvel mais divulgado é o pentaclorofenol. Em geral, os preservativos hidrossolúveis mais comercializados são: arseniato de cobre cromatado (CCA); arseniato de cobre amoniacal (ACA); sais de Cobre, cromo e boro (CCB); cloreto de zinco cromatado (CZC); cromato de cobre ácido (ACC).

Com base na bibliografia consultada (ver a seguir, itens 2.3.3 e 2.3.4), foi verificada a maior importância dos preservativos hidrossolúveis (CCA e CCB). Estes produtos são indicados para as mais diversas aplicações, tais como projetos de jardinagem, suportes de culturas vegetais, floreiras, mobiliário, equipamentos de playgrounds, painéis de vedação e, obviamente, na construção civil em geral. Por estes motivos, tais produtos serão apresentados com maiores detalhes.

\subsubsection{Arseniato de cobre cromatado (CCA)}

Segundo LEPAGE et al. (1986), o CCA foi desenvolvido independentemente a partir de três origens e é composto por sais de cobre, cromo e arsênio em proporções adequadas.

A primeira formulação ocorreu em 1926, na Escócia, do produto Celcure, baseado na composição entre o sulfato de cobre dicromado e ácido acético. Mais tarde, o último componente foi substituído pelo ácido bórico e depois pelo composto de arsênio, dando origem ao Celcure "A".

A segunda origem se deu em 1930 com a criação de um produto à base de arseniatos e bicromatos, conhecido como Falkamesan. Três anos mais tarde, a partir 
da adição do sulfato de cobre, originou-se o produto Ascu, tornando-se o primeiro preservativo do tipo CCA disponível no mercado.

A última origem do CCA é datada de 1932 e desenvolvida pela Companhia Boliden, da Escandinávia. Inicialmente propôs-se um produto formado a partir de duas etapas de tratamento, isto é, arseniato de sódio (célula vazia) e cloreto de zinco (célula cheia), precipitando o arseniato de zinco. Este procedimento foi abandonado em 1936 pelo elevado custo de produção e, em seguida, foi proposto um tratamento com apenas uma etapa, empregando um produto à base de ácido arsênico, arseniato de sódio e sulfato de zinco, denominado por Sal de Boliden BIS. Mais tarde, devido ao baixo rendimento, substituíram-se os sais por óxidos e $25 \%$ do zinco por cobre, originando o produto Boliden S25. Em 1950 todo o zinco foi substituído por cobre, formando o Boliden K33.

Mundialmente, este preservativo pode ser adquirido na forma de sais cristalinos, pasta ou líqüidos concentrados, enquanto no Brasil encontra-se com uma consistência pastosa e coloração castanha avermelhada.

Atualmente, no Brasil, este produto é o mais utilizado pelas usinas de tratamento preservativo, provavelmente em virtude de suas características, ou seja, inodoro, não exala vapores que causam irritação à pele, permite acabamentos do tipo pintura, verniz e laqueamento e, além disto, pode ser empregado em peças de madeira laminada-colada. É conveniente ressaltar que Instituto Americano de Preservadores de Madeira (AWPI), em experiências desenvolvidas com o produto CCA, têm demonstrado que a madeira tratada não oferece riscos à saúde humana. $\mathrm{O}$ mesmo Instituto menciona que pesquisas epidemiológicas desenvolvidas em usinas de preservação de madeiras e em carpintarias não indicaram incidência de casos de contaminação pela exposição à madeira tratada.

De acordo com a Associação Brasileira de Normas Técnicas (ABNT), mais especificamente as normas NBR-6229 - "Postes de eucalipto preservados sob pressão" e EB-474 - "Moirões de madeira preservada para cercas", este produto pode ser fabricado em três formulações, ou seja, tipo "A", "B" e "C". A principal diferença entre eles está na proporção entre os seus principais componentes ativos. A ABNT propõe resumidamente a seguinte distribuição:

TABELA 01 -Proporção entre os componentes ativos - CCA 


\begin{tabular}{c|c|c|c}
\hline \multirow{2}{*}{ Componentes } & \multicolumn{3}{|c}{ Proporção (\%) } \\
\cline { 2 - 4 } & Tipo "A" & Tipo "B" & Tipo "C" \\
\hline $\mathrm{CrO}_{3}$ (Trióxido de cromo) & 65,5 & 35,3 & 47,5 \\
$\mathrm{CuO}$ (Óxido de cobre) & 18,1 & 19,6 & 18,5 \\
$\mathrm{As}_{2} \mathrm{O}_{5}$ (Pentóxido de arsênio) & 16,4 & 45,1 & 34,0 \\
\hline
\end{tabular}

Fonte: RAIMBAULT \& CARLOS (1983).

A uso deste produto no exterior é permitido através das recomendações prescritas em documentos normativos e, entre eles, destacam-se a AWPA (American Wood Preservers' Association), CSA (Canadian Standard Association), BS (British Standard), DIN (Deutsche Internationale Norman) e ASS (Australian Standard Specification).

\subsubsection{Sais de cobre, cromo e boro (CCB)}

Este produto foi desenvolvido na Índia durante a $2^{\text {a }}$ Guerra Mundial e é constituído por sais de cobre, cromo e boro. Vale ressaltar que a utilização da combinação entre o cromo e o boro em soluções preservativas já era empregada desde 1913, LEPAGE et al. (1986). Assim como o CCA, tal produto permite às peças de madeira quaisquer tipos de acabamento. De acordo com as normas da ABNT citadas anteriormente, a composição final do produto é a seguinte:

TABELA 02 -Proporção entre os componentes ativos - CCB

\begin{tabular}{c|c}
\hline Componentes & Proporção (\%) \\
\hline $\mathrm{CuSO}_{4} .5 \mathrm{H}_{2} \mathrm{O}$ (Sulfato de cobre aquoso) & 35,8 \\
$\mathrm{H}_{3} \mathrm{BO}_{3}$ (Ácido bórico) & 22,4 \\
$\mathrm{~K}_{2} \mathrm{Cr}_{2} \mathrm{O}_{7}$ (Dicromato de potássio) & 38,5 \\
$\mathrm{NaHSO}_{4}$ (Bissulfato de sódio) & 2,1 \\
Outros & 1,2 \\
\hline
\end{tabular}

Fonte: RAIMBAULT \& CARLOS (1983).

\subsubsection{Panorama da preservação no Brasil}

O desenvolvimento e a utilização dos processos preservativos, no Brasil, aconteceram de maneira defasada, se comparadas com outros países, principalmente em relação à países da Europa e aos Estados Unidos da América. Tal fato ocorreu em virtude das grandes matas virgens de madeiras duráveis existentes até meados do século XX.

Desde então, a redução das áreas produtoras de madeiras nativas se deu pela exploração descontrolada e sem manejo florestal bem conduzido. 
$\mathrm{O}$ ataque indiscriminado às espécies de madeiras duráveis existentes na Mata Atlântica teve como principal causa a expansão das ferrovias, utilizando-as como dormentes. Neste caso, foi necessária a utilização de espécies alternativas, com durabilidade natural inferior às primeiras e, para que pudessem atingir vida útil satisfatória, passou-se a usar a preservação química. Segundo CAVALCANTE (1982), foi entre 1880 e 1884 que ocorreu a preservação das primeiras peças de madeira, em particular, os dormentes. Tais elementos foram submetidos à impregnação sem pressão, utilizando o creosoto.

De acordo com CAVALCANTE (1982), RAIMBAULT \& CARLOS (1983) e LEPAGE et al. (1986), a primeira usina de preservação de madeira sob pressão, através de autoclaves, foi adquirida da Inglaterra, em 1900, e instalada na Estação Francisco Bernardino, município de Juiz de Fora, Estado de Minas Gerais. Esta usina era composta por um autoclave com 14,4 metros de comprimento e 1,82 metro de diâmetro. Começou a operar em 1902 ou 1904, promovendo a impregnação de dormentes com creosoto. Nessa mesma época, em 1903, através do pesquisador Edmundo Navarro de Andrade, deu-se início à produção em escala industrial de várias espécies de eucaliptos. Segundo ANDRADE (1911), dois anos mais tarde, em uma fazenda no município de Araras, Estado de São Paulo, postes deste gênero foram tratados. Não se sabe ao certo se sustentavam cabos elétricos, de telegrafia ou telefone, ou se desempenhavam a função de moirões de cerca. Em 1916, algumas espécies foram utilizadas sem tratamento preservativo, na forma de postes roliços, para linhas telefônicas do Estado de São Paulo, obtendo-se uma vida útil de aproximadamente seis anos. Outras tentativas foram realizadas em 1922, 1928/29. Somente em 1935, na cidade de Rio Claro, Estado de São Paulo, foram empregados postes de eucaliptos tratados com creosoto, através do Processo de Banho QuenteFrio. Após vinte e seis anos verificou-se o bom estado dos mesmos, ANDRADE (1961).

De acordo com CAVALCANTE (1982), RAIMBAULT \& CARLOS (1983) e LEPAGE et al. (1986), na década de 30, em 1936, foi fundada em Rio Claro, pela firma "Preservação de Madeira Ltda", atual "Tintas de Preservação de Madeira S.A. (Prema)", a segunda usina de preservação, sendo a primeira de capital privado. Inicialmente, foi utilizado tratamento pelo Processo Banho Quente-Frio com 
creosoto e, posteriormente, passou a empregar o Processo de Boucherie com preservativo à base de fluoreto-dicromato-dinitrofenol, sempre com o objetivo de tratar postes de eucaliptos para a rede de energia elétrica. Mais tarde, em 1945, foi instalada uma usina de tratamento sob pressão, empregando ainda o mesmo produto e processo de tratamento e, somente em 1961, deu-se início à utilização do produto à base de cobre-cromo-boro, mais conhecido como CCB. Segundo os mesmos autores, em 1947 ocorreu a instalação da terceira usina de preservação de madeira, no Instituto de Pesquisas Tecnológicas do Estado de São Paulo (IPT), sendo a primeira com finalidade de pesquisa.

O crescimento das áreas de reflorestamento de espécies de Eucalipto e Pinus, e a homologação da Lei Federal no 4797, de 20/10/1965 regulamentada pelo Decreto 58010 de 18/03/1966, cujo conteúdo principal era estabelecer a obrigatoriedade do tratamento preservativo para todas as peças de madeira utilizada em serviços públicos, contribuíram para o desenvolvimento da preservação no Brasil e, consequentemente, para o aumento da quantidade de usinas de tratamento. FREITAS \& GERALDO (1982) e CAVALCANTE (1983) comprovam este fato com os seguintes dados: 12 usinas voltadas à preservação de dormentes e 29 destinadas ao tratamento de postes, moirões e outros tipos de peças de madeira. Todavia, em 2001, a Associação Brasileira de Preservadores de Madeira (ABPM) registra apenas 28 empresas produtoras de madeira tratada, distribuídas nos Estados da seguinte maneira: São Paulo (14), Paraná (04), Rio Grande do Sul (04), Minas Gerais (03), Mato Grasso do Sul (02) e Espírito Santo (01).

Segundo a ABPM, atualmente o Brasil possui 10 indústrias produtoras de preservantes de madeira, sendo que, todos os produtos químicos empregados na preservação são produzidos internamente, com matérias-primas (arsênio, cobre e pentaclorofenol) importadas. Dentre os produtos atualmente comercializados, destacam-se os hidrossolúveis (CCA e CCB).

De acordo com CAVALCANTE (1983) e RAIMBAULT (1983), o creosoto tem sido utilizado desde o início da preservação no Brasil, enquanto o pentaclorofenol passou a ser importado e empregado a partir de 1957. Começou a ser produzido em 1967 e, devido à elevada toxidez, sua fabricação foi interrompida em 1978. O emprego do preservativo hidrossolúvel tipo CCA no Brasil teve início em 
1959 e, a partir de 1975, passou a ser produzido. O CCB, por sua vez, é empregado e produzido no país desde 1961.

Nos últimos anos, tem-se notado uma tendência de acréscimo de uso dos preservativos hidrossolúveis em relação aos produtos oleossolúveis. Segundo RAIMBAULT (1983), através da análise quantitativa realizada com postes de Eucalipto entre 1975 e 1977, pode ser comprovado um consumo de 54\% com preservativos hidrossolúveis e $46 \%$ com oleossolúveis. A partir de pesquisas comparativas entre 1978/79, realizadas por FREITAS \& GERALDO (1982), observou-se um crescimento do consumo (em toneladas) de preservativos hidrossolúveis de aproximadamente $28 \%$, enquanto o consumo de oleossolúveis decresceu em torno de $10 \%$. Segundo os mesmos autores, somente em postes, a relação passou a ser de 59\% com preservativos hidrossolúveis e 41\% com oleossolúveis. Provavelmente, tal fato seja decorrente da elevada toxidez dos oleossolúveis. Outro fator muito importante referente aos hidrossolúveis, diz respeito à ausência de odores, de vapores e de qualquer tipo de resíduo na superfície da madeira após a preservação, além de permitir quaisquer tipos de acabamentos superficiais proporcionando melhor aparência às peças de madeira.

\subsection{Deterioração da madeira}

Como qualquer outro material, a madeira está susceptível à deterioração, causada principalmente por defeitos naturais e agentes deterioradores.

\subsubsection{Defeitos naturais}

A deterioração oriunda dos defeitos naturais (grã irregular, presença de nós, madeira de reação, falso cerne, fendas anelares e bolsões de resinas) está diretamente relacionada ao tipo de espécie e também com a forma de crescimento. 


\subsubsection{Agentes deterioradores}

Toda madeira em seu estado natural está sujeita às ações de agentes deterioradores, sejam de origem biológica ou não. Segundo LEPAGE et al. (1986), tais agentes podem causar desde simples mudança de cor até redução das características físico-mecânicas da madeira, podendo comprometer o desempenho arquitetônico e estrutural das peças.

De acordo com o mesmo autor, os agentes deterioradores da madeira são divididos em dois grupos, ou seja, os agentes abióticos e os bióticos. Além destes, outros fatores podem comprometer a edificação como um todo, como a escolha do material, secagem incorreta, ausência de preservação, forma de armazenagem, processos construtivos, etc.

A pesquisa bibliográfica evidenciou uma certa uniformidade a respeito da divisão citada, ficando uma diferença em função da importância dada a um ou outro agente deteriorador.

\subsubsection{Agentes abióticos}

Os agentes abióticos podem ser divididos em mecânicos, físicos, químicos e climáticos.

Segundo BENEVENTE (1995), a deterioração da madeira pela ação dos agentes mecânicos está diretamente relacionada à dureza da mesma. Como exemplo, podem-se citar os efeitos da abrasão, combinados com os ataques de organismos xilófagos, principalmente os fungos apodrecedores. WILKINSON (1979) afirma que a possibilidade de ocorrência de desgaste mecânico é bastante comum em lugares de muito tráfego de pedestres, por exemplo degraus de escadas e corredores.

A respeito dos deterioradores físicos, o fogo é considerado o principal agente, JUNAC (1988). "Entretanto, do ponto de vista da quantidade de madeira destruída, o fogo é de importância secundária comparado com o apodrecimento, de ação lenta e menos evidente", HUNT \& GARRATT (1962). Tal assunto é bastante abordado por BROCHARD (1960), KARLSEN (1967), LEPAGE et al. (1986) e AGUILLAR FILHO (1986).

A madeira possui certa resistência aos agentes químicos, porém, o contato com algumas substâncias (ácidos e bases fortes, óxido de ferro, dióxido de enxofre, 
sais de sódio) pode proporcionar algumas transformações e reduzir os valores de suas propriedades físico-mecânicas, BENEVENTE (1995). Este tipo de deterioração é facilmente encontrada em pisos de fábricas de produtos químicos e nas peças de madeira em contato com ferragens. Por outro lado, conforme LEPAGE et al. (1986), a madeira possui resistência considerável às soluções neutras, ácidas ou básicas fracas. Assim sendo, usa-se muito na construção de diversos equipamentos, como tanques, filtros-prensas, tonéis, dutos de exaustão de gases e outros, sem que ocorra a deterioração do material. Apesar do exposto, o custo inerente às medidas tomadas contra estes tipos de ataques mostra a viabilidade econômica do emprego da madeira tratada.

Os agentes abióticos de origem natural capazes de deteriorar a madeira podem ser classificados como agentes climáticos, BENEVENTE (1995). Entre eles, destacam-se: umidade, temperatura, radiação solar e ventos. Segundo LEPAGE et al. (1986), a ação conjunta de todos estes efeitos pode ser resumida por "WEATHERING". Além destes, os poluentes contidos na atmosfera também podem causar tal dano nas peças de madeira.

Agentes como a umidade e a temperatura, quando combinados podem tornar o ambiente propício a ataques de microorganismos, principalmente fungos apodrecedores. A oscilação freqüente destes agentes pode causar variações dimensionais, provocar rachaduras, empenamentos, fendilhamentos, principalmente nas extremidades das peças, onde a absorção e a perda de umidade ocorrem com maior rapidez.

A degradação fotoquímica ocasionada pela radiação ultra-violeta altera a cor da madeira, recebendo o nome de envelhecimento natural. Este fenômeno, agindo ao longo da peça, conjuntamente com as intempéries (águas da chuva, ventos), pode provocar o aparecimento de pequenas fissuras, tornando a madeira áspera e enrugada. Deste modo, as fibras da superfície tornam-se quebradiças e vão se desgastando gradualmente, levando à deterioração das peças de madeira, HUNT \& GARRATT (1962) e LEPAGE et al. (1986).

\subsubsection{Agentes bióticos}

Os agentes de origem biológica são considerados os principais deterioradores da madeira, CAVALCANTE (1982). 
Em razão da sua composição básica, que inclui celulose, lignina e hemicelulose e, em menor proporção, amido e açúcares, a madeira está exposta e sujeita à ação de seres vivos que a utilizam como fonte de alimentação ou como habitação.

Conforme a literatura, os organismos que atacam a madeira são divididos da seguinte maneira:

a) Microorganismos: Fungos (apodrecedores, manchadores e emboloradores) e Bactérias;

b) Insetos: Hemíptera (escaravelhos e percevejos), Lepidóptera (borboletas e mariposas), Díptera (moscas e mosquitos), Hymenóptera (vespas, abelhas e formigas), Coleóptera (brocas e besouros) e Isóptera (cupins);

c) Perfuradores marinhos: Moluscos e Crustáceos.

O processo de deterioração provocado por estes organismos é tido como biodeterioração. Dentre os organismos xilófagos, é oportuno e conveniente registrar apenas aqueles que atuam com maior freqüência e que possam vir a provocar danos à resistência mecânica da madeira, ou seja, os fungos apodrecedores e os insetos (ordens isóptera e coleóptera).

\section{a) Microorganismos - fungos apodrecedores}

Os fungos são vegetais aclorofilados, incapazes, portanto, de sintetizar seu próprio alimento através da fotossíntese. Por este motivo, necessitam de materiais orgânicos e, para isso, utilizam a madeira como principal fonte de alimento. $\mathrm{Na}$ madeira, tanto nas folhosas como nas coníferas, o ataque se dá preferencialmente no alburno, devido à maior presença de nutrientes.

De acordo com HUNT \& GARRATT (1962), CAVALCANTE (1982) e LEPAGE et al. (1986), o apodrecimento da madeira é uma decomposição química causada pelos fungos apodrecedores (fungos xilófagos). Tais microorganismos atacam as paredes celulares, alterando de forma irreversível as propriedades físicomecânicas e químicas das mesmas. Segundo os mesmos autores, devido às suas atividades enzimáticas, os fungos apodrecedores são convenientemente classificados 
em podridão mole ou soft rot (capacidade limitada de deterioração) e podridão parda ou brown rot e branca ou white rot (alta capacidade de deterioração).

Os fungos causadores da podridão parda atacam predominantemente a celulose e hemicelulose, CAVALCANTE (1982). A lignina, apesar de não ser usada como nutriente, é alterada e degradada. Como conseqüência do apodrecimento, a madeira apresenta, na superfície, pequenas fissuras transversais e longitudinais às fibras, formando um reticulado característico, tornando-a quebradiça devido à redução do tamanho e da espessura da parede celular.

Os fungos causadores da podridão branca atacam uniforme $\mathrm{e}$ progressivamente a celulose, a hemicelulose e a lignina, com predominância para a última, LEPAGE et al. (1986). A cor esbranquiçada da madeira, oriunda do apodrecimento, deve-se à remoção dos materiais corantes, SCHEFFER (1973). Diferentemente da podridão parda, a aparência das peças atacadas pela podridão branca mantém-se praticamente inalterada, exceto as linhas escuras demarcando a região afetada. Conforme CAVALCANTE (1982) e LEPAGE et al. (1986), ambos podem atacar porções profundas da madeira.

Segundo KOLLMANN (1968) e SCHEFFER (1973), os estudiosos Findlay e Savory observaram, em 1950, em torres de resfriamento, um tipo diferente de ataque por fungos, ocasionando apenas deterioração superficial da peça de madeira. Tal decomposição era parecida com a podridão parda, porém deixava a superfície da madeira amolecida, razão pela qual Savory denominou de soft rot. A superfície infectada pode ser facilmente retirada e observa-se que a transição entre a madeira atacada e a parte sã é repentina. Tais microorganismos, os fungos causadores da podridão mole, atacam somente a superfície da madeira, não atingindo profundidades maiores que 20 milímetros, CAVALCANTE (1982) e LEPAGE et al. (1986). De acordo com KOLLMANN \& COTÊ (1968), estes ataques provocam algumas transformações em nível estrutural, ou seja, perda de massa, redução da massa específica aparente e diminuição da resistência mecânica. Do ponto de vista estético, as conseqüências estão voltadas para a mudança na coloração e aparecimento de manchas na superfície das peças de madeira. Vale ressaltar que ambas as situações provocam perdas econômicas. 
Para que estes tipos de microorganismos possam se desenvolver, devem ocorrer condições ideais, isto é, teor de umidade, temperatura e pH adequado, oxigênio, ausência de substâncias tóxicas e outras. Em situações onde os fungos já tenham se instalado, a ausência de quaisquer condições é suficiente para inibir sua proliferação.

De acordo com CAVALCANTE (1982), peças de madeira que apresentam umidade acima de $20 \%$ estão sujeitas à proliferação de fungos. Segundo o mesmo autor, a umidade ideal para o desenvolvimento de tais organismos deverá ser acima do ponto de saturação das fibras (PSF), ou seja, aproximadamente $30 \%$. O valor máximo depende da espécie, mas deverá ser sempre inferior à umidade de saturação. A temperatura ideal para a proliferação de fungos está em torno de 25 graus centígrados. Quanto ao $\mathrm{pH}$, a faixa para seu desenvolvimento varia entre dois e sete, porém os valores ótimos se encontram em torno de cinco.

\section{b) Isóptera - cupins ou térmitas}

Os cupins, também conhecidos como térmitas, utilizam a madeira como alimento e como meio físico de hospedagem, mas em quaisquer situações causarão prejuízo. Ao contrário dos fungos apodrecedores, a destruição causada pelos cupins se dá através da escavação da estrutura da madeira, resultando em galerias e, consequentemente, alterando a resistência mecânica da mesma.

Dentre os organismos da Classe Insecta, os cupins são os que mais causam dano à madeira, CAVALCANTE (1982). A extensão dos danos é diretamente proporcional às condições de uso, do tipo de inseto e da espécie da madeira. Segundo LELIS (1975/76), os cupins podem ser divididos em duas grandes categorias, isto é, cupins que vivem no solo (ou em contato com o solo) e cupins que vivem na madeira. A primeira categoria vive no solo ou em contato com o mesmo, de onde retira umidade necessária para sua sobrevivência. Estes insetos chegam a atingir peças de madeira a grandes distâncias do solo e, em função da intensidade de seus ataques, podem vir a causar problemas estruturais em quaisquer edificações. De acordo com a bibliografia, alguns autores dividem esta categoria da seguinte maneira: subterrâneos, epígeos (murunduns) e arbóreos. 
No segundo caso, a madeira é útil para os insetos, tanto para abrigo como alimentação. Em função da umidade, se dividem em cupim de madeira seca e cupim de madeira úmida. Os cupins de madeira seca têm na madeira seu hábitat e somente a umidade da madeira (10 a 12\%) é suficiente para sua sobrevivência. Os ataques nas peças de madeira se desenvolvem lentamente, porém são freqüentes, podendo provocar sérios danos. Geralmente, são detectados quando a parte interna da peça está parcial ou totalmente destruída. Na maioria das vezes, estes insetos são detectados pela presença de grânulos (fezes) próximos à peça atacada. O cupim de madeira úmida ataca exclusivamente peças de madeira com teor de umidade mais alto, com princípio de apodrecimentos, mas também. podem atacar peças sem que exista proliferação de fungos.

\section{c) Coleóptera - brocas e besouros}

Esta ordem é a maior da Classe Insecta, correspondendo a aproximadamente 40\% do total de espécies, LEPAGE et al. (1986). Segundo CAVALCANTE (1982), “...depois dos cupins, os insetos que maiores danos causam às madeiras pertencem à Ordem Coleóptera". Dentre as famílias desta Ordem, algumas usam a madeira como fonte de alimentação - desde a árvore viva até bem seca - num gradiente decrescente de umidade, LEPAGE et al. (1986). Segundo o mesmo autor, as brocas atacam mecanicamente as paredes celulares através de mandíbulas, podendo digerir a holocelulose (celulose e hemicelulose) e o conteúdo de algumas células parenquimáticas.

\subsection{Propriedades da madeira}

A madeira é um ser vivo, de origem vegetal, formada a partir de um conjunto heterogêneo de diferentes tipos celulares, com múltiplas funções, desde a condução de líqüidos; transformação, armazenamento e transporte de substâncias nutritivas; até a sustentação da árvore, entre outras. De acordo com a formação anatômica, o vegetal passa a ter comportamentos específicos, ditados pelas propriedades físicas, mecânicas e de resistência natural.

Para o desenvolvimento de projetos estruturais, deve-se conhecer previamente as propriedades físicas, mecânicas (resistência e elasticidade), bem 
como a resistência natural do material a ser utilizado. A obtenção de um maior ou menor aproveitamento do ponto de vista estrutural é quantificado a partir das propriedades físico-mecânicas, enquanto a resistência natural é de grande valia na análise da durabilidade da peça de madeira. Na bibliografia consultada, foram encontradas referências significativas a respeito das referidas propriedades, seja para as espécies nativas como para as de reflorestamento.

O INSTITUTO DE PESQUISAS TECNOLÓGICAS DO ESTADO DE SÃO PAULO (1956) traz os valores de diversas propriedades de espécies nativas e de reflorestamento.

Em 1989, MAINIERI \& CHIMELO, apresentaram propriedades físicomecânicas e de resistência natural de 200 espécies nativas brasileiras.

Resumidamente, a norma brasileira NBR 7190/97 - Anexo "E” (Tabelas E.1, E.2 e E.3) apresenta os valores mais relevantes de algumas espécies nativas e de reflorestamento (Pinus e Eucalipto). MELO (1981/97) e SOUZA (1997) também apresentaram propriedades físico-mecânicas de algumas espécies nativas. Quanto a resistência à deterioração devida à ação dos agentes biológicos e permeabilidade às soluções preservantes são apresentadas com maiores detalhes por MAINIERI \& CHIMELO (1989).

ROCCO LAHR (1992) avaliou as propriedades físicas e mecânicas de espécies, chamadas de alternativas para aplicação na construção de estruturas, incluindo entre elas algumas do gênero Pinus. Ficou evidenciada a possibilidade de emprego estrutural das mencionadas espécies, uma vez conduzidos adequadamente os cálculos estruturais, e garantido o tratamento preservativo contra a demanda biológica.

Mais recentemente, BORTOLETTO Jr. (1993) apresentou trabalho, baseado nas propriedades físico-mecânicas, cujo objetivo era indicar as utilizações mais convenientes para diversas espécies e variedades de Pinus crescidos no Estado de São Paulo.

As propriedades físicas, de resistência e de elasticidade mais relevantes das espécies de Eucaliptos também são apresentadas por SALES (1991) e NOGUEIRA (1991). 
A Revista Téchne - nov/dez - 1995, nº 19 apresenta alguns valores referentes à resistência natural e permeabilidade de algumas espécies de Pinus e Eucalipto.

\subsubsection{Propriedades físicas}

Do ponto de vista estrutural, as características físicas mais importantes são a umidade, a retratibilidade e a massa específica aparente (densidade aparente).

\subsubsection{Umidade}

Trata-se de um parâmetro muito importante, por ter influência direta sobre todas as outras propriedades da madeira, sejam elas de resistência, de elasticidade e até mesmo sobre outras propriedades físicas. $\mathrm{O}$ teor de umidade também auxilia na escolha do método mais apropriado para preservar a peça de madeira.

De acordo com a NBR 7190/1997, Anexo "B" - item 5.2, a umidade da madeira é definida como sendo a relação entre a massa de água existente na peça e a massa seca da mesma peça.

No interior da madeira, a água pode ocorrer em três situações distintas, ou seja, água livre (embebição ou capilaridade), água de impregnação (adesão) e água de constituição. A primeira está presente no interior das células (lúmen) e nos espaços intercelulares, e sua perda se dá por capilaridade, pela passagem de uma célula à outra até a superfície. As moléculas de água de impregnação ou de adesão mantêm-se unidas às microfibrilas da parede celulósica dos elementos anatômicos (células dos vasos, traqueídes, fibras, parênquimas axiais e raios medulares), e sua eliminação ocorre mais facilmente através da secagem artificial, pelo processo de difusão. As moléculas de água de constituição encontram-se quimicamente unidas aos constituintes da parede celular e, quando eliminadas, provocam alterações na composição química da parede celular.

O limite entre a água livre e a água de adesão foi definido como Ponto de Saturação das Fibras (PSF) e, dependendo da espécie, o valor se encontra na faixa de 22 a 30\%. A NBR 7190/1997 adota o valor convencional de $25 \%$ para o PSF.

\subsubsection{Estabilidade dimensional (retratibilidade ou inchamento)}


$\mathrm{O}$ fato de a madeira ser um material altamente higroscópico produz o fenômeno de retração e inchamento (variação da umidade da madeira em patamares inferiores a PSF), isto é, redução e aumento volumétrico, respectivamente. Segundo KARLSEN (1967), entre outros autores, estas variações ocorrem de forma diferenciada em cada uma das três direções principais: axial (aproximadamente 0,1 $\%$ ), radial (3 a 6\%) e tangencial (6 a 12\%). Tal estabilidade é responsável ou explica a maioria dos defeitos ocorridos durante a secagem. Este comportamento é conseqüência, principalmente, do ângulo fibrilar da camada " $\mathrm{S}_{2}$ " da parede secundária, pois, compõe aproximadamente $75 \%$ do volume da parede celular, TOMAZELLO (1996). Portanto, o acréscimo da variação volumétrica está diretamente relacionado com o aumento do ângulo fibrilar. Segundo MOREY (1980), o ângulo das microfibrilas da camada " $\mathrm{S}_{2}$ " varia entre 10 e 30 graus.

Geralmente, pode-se dizer que as folhosas (dicotiledôneas) são mais susceptíveis às variações volumétricas que as coníferas (gimnospermas). Este fato pode ser entendido baseando-se em diferenças existentes na composição química da madeira. MOREY (1980) afirma que, na maioria das vezes, a porcentagem de hemicelulose presente nas dicotiledôneas é superior àquelas encontradas nas gimnospermas e, conseqüentemente, a porcentagem de lignina é menor.

De acordo com MOREY (1980), dentre os principais elementos químicos que compõem a parede celular, a hemicelulose é a mais higroscópica. Assim sendo, pode-se entender a causa das diferentes variações volumétricas entre as angiospermas dicotiledôneas e gimnospermas.

Segundo a NBR 7190/1997, item B.7.2, a quantificação da estabilidade dimensional é dada com base nas deformações específicas de retração e inchamento, bem como na variação volumétrica, considerando corpos-de-prova saturados e secos.

\subsubsection{Massa específica aparente e densidade básica}

De acordo com a literatura consultada, foi possível observar a unanimidade dos pesquisadores quanto à importância do conhecimento da massa específica aparente e densidade básica, principalmente no que diz respeito à análise da qualidade das madeiras. Tais propriedades, conforme a NBR 7190/1997, item B.6, podem ser definidas da seguinte maneira: 
a) Massa específica aparente $\left(\rho_{\mathrm{ap}}\right)$ : é a relação entre a massa de uma amostra e o seu volume, para um determinado teor de umidade,

b) Densidade Básica $\left(\rho_{\mathrm{bas}}\right)$ : é a relação entre a massa de uma amostra anidra $(0 \%$ de umidade) e o volume saturado.

Ambas as propriedades dependem de vários fatores, entre eles, a espécie, o volume de poros, espessura da parede celular, rearranjo e tamanho das células, a quantidade de extrativos por unidade de volume, etc. Dentro de uma mesma árvore, podem existir variações destas propriedades, tanto no sentido base-topo como no sentido medula-casca. No âmbito estrutural, a massa específica aparente é considerada a propriedade física mais significativa, pelo fato de estar intimamente relacionada com a resistência mecânica da madeira. De modo geral, pode-se dizer: quanto maior a massa específica aparente, maior será a resistência mecânica da madeira, considerando como referência, o mesmo nível de umidade. Além disto, o peso próprio de quaisquer estruturas é calculado em função deste parâmetro.

\subsubsection{Propriedades mecânicas (resistência e elasticidade)}

As propriedades de resistência e de elasticidade estão relacionadas com a composição química e com as propriedades físicas e anatômicas da madeira.

Das propriedades mecânicas definidas pela NBR 7190/1997, item B.1, serão enfatizadas somente aquelas diretamente envolvidas na análise de projetos estruturais. Neste caso, tal abordagem poderá ser dividida em dois grupos: propriedades de resistência: compressão, tração e cisalhamento paralelo às fibras; propriedade de elasticidade: compressão paralela às fibras.

A metodologia de obtenção destes valores é apresentada no Anexo "B" da NBR 7190/1997.

\subsubsection{Resistência natural}

A resistência natural é definida como a capacidade inerente a uma espécie de resistir à ação de agentes deterioradores, incluindo os agentes bióticos e abióticos, sem tratamento preservativo, BENEVENTE (1995).

A vida útil de uma peça de madeira em serviço depende da sua resistência natural e de um meio ambiente não propício a ataques de organismos xilófagos, TRADA (1991). Segundo o mesmo autor, a classificação da madeira quanto à 
resistência natural é dada em função do desempenho de seu cerne em contato direto com o solo, conforme tabela abaixo:

TABELA 03 - Classificação das madeiras segundo sua durabilidade natural

\begin{tabular}{c|c}
\hline Grau de durabilidade & Vida média em contato com o solo \\
\hline muito durável & 25 anos \\
durável & $15-20$ anos \\
moderadamente durável & $10-15$ anos \\
não durável & $5-10$ anos \\
perecível & até 5 anos \\
\hline Fonte: Revista Téchne $-\mathrm{nov} / \mathrm{dez}-1995, \mathrm{n}^{\mathrm{o}} 19$.
\end{tabular}

\subsection{Preservação x Propriedades mecânicas}

A preservação da madeira é de extrema relevância em qualquer país do mundo, principalmente, naqueles situados nas regiões tropicais. Nestes países, incluindo o Brasil, há uma enorme quantidade de espécies de madeira e, entre elas, existem algumas com grande susceptibilidade à demanda biológica, seja pelos agentes bióticos ou abióticos. Segundo a maioria dos pesquisadores, a preservação é justificável através de algumas razões básicas, ou seja: existência de numerosas espécies de agentes xilófagos, principalmente os fungos apodrecedores e insetos (cupins); condições climáticas favoráveis à proliferação dos mesmos e susceptibilidade por parte de algumas espécies.

Com base no assunto mencionado, WANGAARD (1950) e HUNT \& GARRATT (1953), observaram que, geralmente os ensaios apresentavam redução nas propriedades de resistência. Afirmam também que tal fato estava completamente relacionado com o "binômio" temperatura/pressão na qual a madeira ficara submetida durante o processo de preservação. $\mathrm{Na}$ época, a prática comercial indicava a utilização de soluções de cloreto de zinco (concentrações entre 2 e 5\%), considerada inativa às propriedades do material, porém tornava-a um tanto quebradiça quando submetida ao impacto. Entretanto, para soluções com alta concentração e elevadas temperaturas, também seria capaz de provocar degradação na madeira. Os mesmos autores ressaltam que estas conclusões não são aplicáveis aos produtos hidrossolúveis à base de sais, pois os procedimentos de tratamento são diferentes.

Em face do mesmo problema, EGGLESTON (1952) preservou postes de Southern Pine, utilizando preservativos à base de sais, com objetivo principal de 
verificar o efeito sobre as propriedades do material. Tal experiência foi desenvolvida através de ensaios de flexão estática em postes com dimensões comerciais e, como resposta, foi observado um acréscimo insignificante sobre a resistência.

BURMESTER \& BECKER (1963), empregando dez tipos de preservativos hidrossolúveis à base de sais e considerando um nível de retenção variando de 8 a 24 $\mathrm{Kg} / \mathrm{m}^{3}$, verificaram a influência sobre as propriedades mecânicas de algumas espécies de Pinus. Da experiência, observaram uma variação muito pequena da resistência dos elementos submetidos a ensaios de flexão estática, de compressão paralela e perpendicular às fibras, enquanto a resistência ao impacto na flexão foi reduzida significativamente. BURMESTER (1970), empregando um nível de retenção de aproximadamente $9 \mathrm{Kg} / \mathrm{m}^{3}$ de um preservativo composto por sais de fluoreto-cromo, constatou-se um acréscimo nas resistência à flexão estática e à compressão paralela às fibras.

Em 1964, HESP impregnou alguns elementos de Scots Pine com preservativo hidrossolúvel do tipo CCA com retenção em torno de $4 \mathrm{Kg} / \mathrm{m}^{3}$ e analizou a influência sobre determinadas propriedades mecânicas. Foi verificado que, de maneira geral, a média dos valores da resistência à flexão estática, ao impacto na flexão, à compressão paralela, bem como ao cisalhamento paralelo às fibras pode ser considerada equivalente à média dos valores obtidos para os elementos sem o tratamento preservativo.

Trabalho desenvolvido por TOOLE (1971), mostrou que os corpos-de-prova de alburno de Southern Pine apresentaram redução significativas no limite de resistência ao esmagamento (até 40\%) quando tratados com pentaclorofenol, comparando-se com os valores da madeira sem preservação. Foram utilizadas retenções de até 2 quilos de ingrediente ativo por metro cúbico de madeira.

De acordo com TERENTJEV (1972), nenhum efeito foi verificado sobre a resistência à flexão estática da madeira de Scots Pine, quando os mesmos foram impregnados com $15 \mathrm{Kg} / \mathrm{m}^{3}$ do preservativo ACC.

PERRIN (1978) avaliou o efeito do desdobro sobre as propriedades de resistência das madeiras sem tratamento preservativo; o mesmo autor, porém, comenta a necessidade de pesquisas referentes às citadas propriedades da madeira tratada sob vácuo/pressão. 
Segundo pesquisas realizadas por EATON et al. (1978), evidenciaram-se os prejuízos causados a algumas propriedades mecânicas das estacas de Douglas-fir e de Southern Pine, quando as mesmas foram preservadas por produtos hidrossolúveis dos tipos CCA e ACA. Foi observado que, independentemente da espécie e do produto empregado, obteve-se para a resistência à flexão estática uma redução média variando entre 20 e $60 \%$, enquanto a redução média para o módulo de elasticidade atingiu os patamares de 10 a $45 \%$.

THOMPSON (1980), estudando o efeito da preservação química sobre pressão em propriedades do Southern Pine, chegou a conclusão que reduções de no máximo 5 e $6 \%$ ocorrem, respectivamente, no módulo de resistência à flexão e no módulo de elasticidade longitudinal obtido no ensaio de flexão estática, para elevadas retenções de CCA (superiores a 15 quilos de ingrediente ativo por metro cúbico de madeira), em comparação com madeira não tratada.

RESCH \& PARKER (1982), empregando um tratamento duplo (ACA e creosoto; CCA e creosoto), avaliaram o efeito da preservação sobre a rigidez e a resistência à flexão estática de estacas destinadas a ambientes marinhos, bem como de corpos-de-prova padronizados obtidos das mesmas. Além disto, analisaram também o efeito da impregnação sobre a resistência à compressão paralela às fibras em corpos-de-prova padronizados obtidos das citadas estacas. Para tanto, foram utilizadas madeiras de Southern Pine e Douglas-fir. Segundo os autores, a partir dos resultados obtidos, verificou-se que a variação do módulo de elasticidade das estacas de Southern Pine não foi estatisticamente significativo. Em contrapartida, a resistência e rigidez das estacas de Douglas-fir foram fortemente afetadas. Para os corpos-de-prova à flexão foi verificado que a preservação não reduziu significativamente as propriedades mecânicas, exceto a resistência do Southern Pine. No que diz respeito à compressão, não foi verificado redução das propriedades mecânicas em ambas as espécies estudadas.

BENDTSEN; GJOVIK; VERRIL (1983), avaliaram o efeito do tratamento preservativo sobre a resistência à flexão estática em corpos-de-prova de Longreaf Pine. Para tanto, foram empregados produtos hidrossolúveis do tipo ACA e CCA, com retenções variando de quatro a 40 quilos de ingrediente ativo por metro cúbico de madeira e re-secagem (secagem após a preservação) em estufas e ao ar livre. 
Nesta avaliação, utilizou-se o segundo produto em duas proporções, ou seja, CCA-I com $61 \%$ de cromo e o CCA-II com 35,3\%. Vale ressaltar que o ACA não contém cromo em sua composição. A partir da realização dos ensaios, pode-se observar que a máxima redução da resistência, para corpos-de-prova secos ao ar livre, ocorreu para o maior nível de retenção, ou seja, 17\% para CCA-I, 4\% para CCA-II e 8 a 10\% para os demais casos.

Em 1986, MITCHELL \& BARNES verificaram a influência da temperatura de re-secagem nas propriedades de resistência e de elasticidade da madeira Southern Pine tratada com preservativo hidrossolúvel CCA - Tipo A. Como resultado, foi verificado que a re-secagem artificial em patamares de temperaturas inferiores a $85^{\circ} \mathrm{C}$, as citadas propriedades são afetadas, porém, de maneira insignificante. Todavia, estes pesquisadores comentam que, à temperatura ambiente, tais propriedades também poderão ser afetadas pela impregnação do mencionado produto químico.

WINANDY \& BOONE (1988), analisaram o efeito do preservativo hidrossolúvel CCA, bem como do método de re-secagem nas propriedades de flexão estática da madeira de Southern Pine. Também foi objeto de estudo a qualidade da madeira, ou seja, a presença ou não da medula nos elementos empregados. Deste trabalho pode-se observar que, para madeiras de mesma categoria, a influência da preservação nos valores da resistência aumenta com nível de tensão (zona de plastificação). Porém, para o nível de tensão referente à zona elástica, a preservação torna-se relevante para as propriedades de resistência, quando consideradas as madeiras de segunda categoria. Em contrapartida, para as propriedades elásticas as variações podem ser desprezadas.

Segundo RONAI (1989), a norma húngara "MSz 10144”, de acordo com o método de aplicação, especifica seis categorias de preservação:

TABELA 04 - Método de aplicação e categorias de preservação

\begin{tabular}{c|c|c}
\hline Código & Descrição & Especificação \\
\hline TV & Proteção completa & Preservação de toda a massa da madeira \\
SV & Proteção do alburno & Tratamento de $85 \%$ do alburno \\
MH & Proteção profunda & Penetração de $10 \mathrm{~mm}$ do preservativo \\
HV & Proteção média & Penetração de 1 a $10 \mathrm{~mm}$ do preservativo \\
FV & Proteção superficial & Penetração de $1 \mathrm{~mm}$ do preservativo \\
BV & Proteção da extremidade & Proteção da extremidade com preservativo \\
\hline
\end{tabular}

Fonte: Ronai, F. (1989). 
O mesmo autor, após a preservação completa em corpos-de-prova de Picea Excelsa, observou a variação nos valores de algumas propriedades mecânicas do material. Tal experiência foi desenvolvida, principalmente, através de ensaios de tração paralela às fibras e, como resultado, foram obtidos valores inferiores às amostras sem o referido tratamento preservativo. No decorrer da pesquisa, verificouse também um acréscimo da deformação axial, provavelmente ocasionada pela redução do atrito interno entre as fibras da madeira.

À primeira vista, pode-se verificar que, durante a fase elástica do material, o aumento da retenção de produtos preservativos através de processo sob vácuo/pressão é desfavorável às propriedades mecânicas. Com base nestas experiências, o referido pesquisador recomenda novas investigações a partir de outras formas de solicitações e, em conseqüência, propõe um fator de redução que relacione a categoria de tratamento preservativo com os valores limites de resistência e de elasticidade, tomando-se a maior redução para a categoria $T V$, diminuindo proporcionalmente até a categoria $B V$.

De acordo com as especificações da norma "MSz 15025", a resistência característica da madeira deve ser modificada segundo um coeficiente de redução de $15 \%$, considerando a preservação completa. Porém, nada menciona a respeito das propriedades de elasticidade.

Segundo TSOUMIS (1991), a introdução forçada de produtos químicos na madeira pode afetar não somente a durabilidade, mas também outras propriedades, entre elas, as de resistência e de elasticidade. Este efeito está diretamente relacionado com as características do preservativo empregado, bem como com as condições de tratamento, ou seja, pressão e temperatura. O mesmo autor comenta que o processo de impregnação com preservativo hidrossolúvel do tipo CCA, pode provocar uma redução progressiva das propriedades mecânicas das peças de madeira, principalmente em postes de Eucalipto e Pinus. Tal fato é conseqüência da separação dos anéis de crescimento, preferencialmente entre o lenho inicial e tardio, e por fendilhamento radial.

SMITH et al. (1993) verificaram o efeito do tratamento através de fluidos gasosos (dióxido de carbono) sobre as propriedades de resistência e de elasticidade, a 
partir de ensaios em corpos-de-prova de Ponderosa Pine solicitados à flexão estática. Neste estudo, foram consideradas a temperatura, a pressão e o tempo de aplicação do produto como variáveis principais, mas os resultados obtidos não foram estatisticamente representativos. Porém, tais pesquisadores nada mencionam a respeito do tratamento preservativo através de produtos químicos hidrossolúveis ou oleosos.

Ainda em 1993, BARNES et al., estudando eventuais influências do tratamento preservativo com CCA e ACQ sob pressão em madeira de Southern Pine, concluíram que a rigidez na flexão não foi afetada por quaisquer tipos de tratamento e que a sua influência na resistência é muitíssimo baixa, podendo ser considerada desprezível. Foram utilizadas concentrações equivalentes à retenção de 9,6 quilos de ingrediente ativo por metro cúbico de madeira, comparando os resultados com os obtidos para madeira natural.

Conforme WINANDY (1989), WINANDY; BOONE; FULLER (1995) e WINANDY (1996) a re-secagem poderia afetar as propriedades mecânicas das peças serradas preservadas sob pressão (método da célula-cheia, preservativo à base de sais de cobre-cromo-arsênio e retenções de 6,4 e 40 quilos de ingrediente ativo por metro cúbico de madeira). Este estudo foi realizado com madeira de Southern Pine e Western Hemlock, levando em consideração os programas de secagem póspreservação, estabelecidos pela AWPA, através de estufas e ao ar livre. De acordo com os resultados obtidos a partir dos ensaios de flexão estática realizados em corpos-de-prova padronizados (padrão americano), verificou-se que as propriedades de resistência e de elasticidade variaram de seis a oito porcento e $11 \%$, respectivamente, quando utilizou-se o programa de re-secagem ao ar livre. Para os programas em estufas, utilizaram-se temperaturas em torno de $116^{\circ} \mathrm{C}$ e verificou-se uma redução de aproximadamente $25 \%$ nas referidas propriedades. Os mesmos autores puderam verificar que, para temperaturas máximas em torno de $80^{\circ} \mathrm{C}$, o processo de secagem posterior ao tratamento preservativo não afeta significativamente as propriedades mecânicas da madeira.

WINANDY (1995b,c), verificou a influência da variação do teor de umidade da madeira, considerando três níveis de teor de umidade $(10,15$ e 23\%), e do tempo de aplicação de carga durante $o$ ensaio nas propriedades mecânicas. O 
desenvolvimento desta pesquisa deu-se através de ensaios de flexão estática, utilizando amostras de madeira serrada de Southern Pine, preservadas com produto hidrossolúvel (tipo CCA) e em madeiras sem preservação. Como conclusão, o autor sugere um coeficiente de redução igual a 0,9 para os valores da resistência à esforços normais, quando for utilizado madeira preservada com CCA de primeira categoria e teor de umidade não superior a $15 \%$. Os resultados obtidos para as demais categorias e para umidade superior a 19\%, mostraram que não houve variações significativas das propriedades de resistência. Portanto, foi sugerido um coeficiente igual a 1,0. Para o módulo de elasticidade, independentemente da categoria e da umidade do corpo-de-prova, sugeriu-se também o mesmo valor, ou seja, um coeficiente igual a 1,0 .

Em 1996, RITTER et al. publicaram um estudo comparativo do efeito dos produtos hidrossolúveis e oleossolúveis na protensão transversal de tabuleiros de pontes. Neste avaliação foram utilizadas peças de madeira serrada de Southern Pine, sete produtos preservativos (quatro hidrossolúveis e três oleossolúveis) e três sistemas de ancoragem. Como resultado, verificou-se uma perda de protensão maior nas pontes protendidas com peças preservadas com produtos hidrossolúveis. Desta forma, mesmo do ponto de vista qualitativo, pode-se observar a influência da preservação na propriedade de compressão normal às fibras.

WINANDY \& LEBOW (1997) analisaram os efeitos do tratamento preservativo sobre as propriedades obtidas no ensaio de flexão em espécies do gênero Pinus. Nesta pesquisa foi utilizado um produto muito similar aos preservativos hidrossolúveis comumente empregados mundialmente, conhecido nos Estados Unidos da América por citrato de cobre amoniacal (CC). Durante o desenvolvimento do trabalho, fez-se o tratamento completo do alburno considerando dois valores de retenções, isto é, 6,4 e 40 quilos de ingrediente ativo por metro cúbico de madeira. No primeiro caso, obteve-se uma redução média de aproximadamente $5 \%$ para o valor da resistência, enquanto para o módulo de elasticidade tal fato não foi observado. A segunda situação registrou uma redução mais acentuada para a resistência, em torno de $12 \%$.

De acordo com o SWIDERSKI (1968), a relação custo/benefício é altamente favorável, principalmente quando a preservação é realizada através de impregnação 
sobre pressão, utilizando os produtos à base de sais (CCA, ACC, ACA, etc) ou creosoto. Com este procedimento, o custo médio da madeira utilizada na construção civil poderá aumentar entre 25 e $35 \%$, porém, a durabilidade da peça em serviço será de três a cinco vezes ao da madeira sem preservação. Com isto fica evidenciada a vantagem do processo químico de preservação e a conseqüente necessidade das pesquisas que avaliam os seus efeitos nas propriedades mecânicas da madeira.

\subsection{Comentários referente a revisão bibliográfica realizada}

Após a vasta revisão bibliográfica apresentada, pode ser constatado a quantidade reduzida de pesquisas referentes à influência do processo preservativo, bem como do produto químico nas propriedades de resistência e elasticidade à compressão e ao cisalhamento paralelo às fibras da madeira. Além disto, vale ressaltar que, no Brasil, a preservação química à base de sais é comumente realizada através da impregnação por vácuo/pressão, desconsiderando possíveis variações das propriedades de resistência e de elasticidade. Portanto, tais fatos colaboram para justificar a extrema relevância do projeto de pesquisa em questão. 


\section{CAPÍTULO 3: MATERIAIS E MÉTODOS}

Neste capítulo serão apresentados os equipamentos empregados nas análises experimentais, bem como as espécies de madeira e os produtos químicos para tratamento. Além disto, apresenta-se a metodologia utilizada no decorrer da pesquisa.

\subsection{Equipamentos}

Nesta pesquisa foram utilizados os instrumentos de medição, de aplicação de força, de secagem e climatização, além da usina de tratamento sob vácuo-pressão para a preservação das peças de madeira.

\subsubsection{Instrumentos de medição}

Dentre os instrumentos de medição utilizados no LaMEM/SET/EESC/USP, serão mencionados aqueles de maior interesse para o desenvolvimento do trabalho.

\section{a) Relógio comparador ou defletômetro}

Este dispositivo mecânico é muito empregado para medidas de deslocamentos lineares (flechas), bem como na obtenção de valores que auxiliam o cálculo das deformações. A sua grande utilização é devida à facilidade de instalação e à sua precisão. Tal instrumento é básico para a medição de flechas e sua sensibilidade atinge até 0,001 milímetro, com curso máximo de 50 milímetros. O relógio comparador utilizado é fabricado pela MITUTOYO.

\section{b) Paquímetro digital}


O instrumento utilizado é da marca TESA - Digit Cal e tem como objetivo principal a obtenção das medidas das dimensões dos corpos-de-prova (CP). A sua sensibilidade é de 0,01 milímetro, enquanto o curso máximo é de 150 milímetros.

\section{c) Balança semi-analítica}

A balança eletrônica digital utilizada foi fabricada pela indústria ACATEC BDC 3300 e sua sensibilidade é de 0,01 gramas. Foi utilizada para a determinação da massa dos CP's.

\subsubsection{Equipamentos para aplicação de forças}

A aplicação de forças em CP's normalizados ocorreu através da Máquina Universal de Ensaio, com objetivo único de determinar as propriedades mecânicas. Devido às suas dimensões, geralmente encontra-se fixado em laboratório. $\mathrm{O}$ equipamento aqui citado é da marca AMSLER, com capacidade máxima de $250 \mathrm{kN}$, podendo ser usado nas escalas de 25,50 e $100 \mathrm{kN}$.

\subsubsection{Equipamentos para secagem e climatização}

$\mathrm{Na}$ pesquisa foram empregadas uma estufa e uma climatizadora para secagem. A estufa é um equipamento utilizado para acelerar a secagem do material, podendo atingir uma temperatura em torno de 105 graus centígrados. $\mathrm{O}$ instrumento empregado é da marca FANEM Ltda, e seu espaço interno permite a secagem de peças com dimensões não superiores a 30 centímetros. A climatizadora também é utilizada para promover uma secagem artificial do material, porém pode atingir uma temperatura máxima em torno de 50 graus centígrados. Suas medidas internas permitem a secagem de peças com dimensões não superiores a 180 centímetros.

\subsection{Materiais de consumo}

No caso em questão, foram utilizadas espécies de coníferas (reflorestamento) e de dicotiledôneas (nativas e de reflorestamento) comercializadas na região central do Estado de São Paulo, próxima a cidade de São Carlos. Os preservativos químicos hidrossolúveis do tipo CCA e CCB tiveram duas procedência distintas. O primeiro, produzido pela empresa MONTANA QUÍMICA S.A. (Osmose K-33 tipo A), adquirido no comércio local (São Carlos), enquanto o segundo foi obtido através de 
doação realizada pela empresa PREMA - PRESERVAÇÃO DE MADEIRA LTDA, situada no município de Rio Claro, Estado de São Paulo.

\subsubsection{Espécies de madeira}

\subsubsection{Seleção das espécies}

A pesquisa foi desenvolvida através da adoção de espécies usuais oriundas das matas nativas e de reflorestamento, comumente empregadas na construção civil e comercializadas pelas serrarias da região de São Carlos.

$\mathrm{Na}$ fase preliminar (item 3.3.2.1) do projeto, optou-se pela utilização das seguintes madeiras: reflorestamento - Pinus (Pinus spp) e Eucalipto Grandis (Eucalyptus. grandis); nativas: Garapa (Apuleia leiocarpa) e Pau-amarelo (Euxylophora paraensis). Na fase final (item 3.3.2.2), o trabalho foi desenvolvido a partir do emprego das espécies de reflorestamento - Pinus Elliottii (Pinus elliottii) e Eucalipto Grandis (Eucalyptus grandis); e das espécies nativas - Angelim (Vatairea $s p$ ), Ipê (Tabebuia sp), Jatobá (Hymenaea sp) e Copaíba (Copaifera sp).

\subsubsection{Produtos preservativos}

No decorrer da pesquisa foram utilizados produtos químicos para a preservação dos CP's e dentre aqueles comumente comercializados, optou-se pelos preservativos hidrossolúveis CCA e CCB. Mais detalhes sobre os mesmos, encontram-se nos itens 2.3.2.1 e 2.3.2.2, do Capítulo 02.

\subsection{Métodos}

De acordo com os objetivos explicitados no item 1.2, propõe-se a metodologia em duas fases, de modo que os mesmos possam ser atingidos.

\subsubsection{Determinação das propriedades físicas da madeira}

\section{a) Umidade ou Teor de umidade}

A umidade dos CP's usados nesta pesquisa foi determinada de acordo com as prescrições contidas na NBR 7190/97 - item 5. O conhecimento deste parâmetro é fundamental para ajustar os valores das propriedades de resistência e de elasticidade dos elementos empregados nos ensaios e, além disto, serve como orientação para a 
escolha do método de preservação preventiva. Para a realização destes ensaios foram empregadas uma balança analítica e uma estufa.

\section{b) Massa específica aparente}

O valor da massa específica aparente de cada CP foi corrigido para umidade de $12 \%$, através do diagrama de Kollmann (Ver Figura 16).

\subsubsection{Determinação das propriedades mecânicas da madeira}

A opção pelas propriedades mencionadas se justifica pelo fato de as mesmas se constituírem em referência pelo texto da NBR 7190/97 além de, obviamente, serem indispensáveis na elaboração de projetos de estruturas de madeira.

\section{a) Compressão paralela às fibras}

$\mathrm{O}$ método de ensaio à compressão paralela às fibras e os CP's usados nesta pesquisa, estão de acordo com as prescrições contidas na NBR 7190/97-Anexo Bitem 8. As figuras 09 e 10 ilustram, respectivamente, os CP's e o equipamento (máquina universal) empregado durante os ensaios.
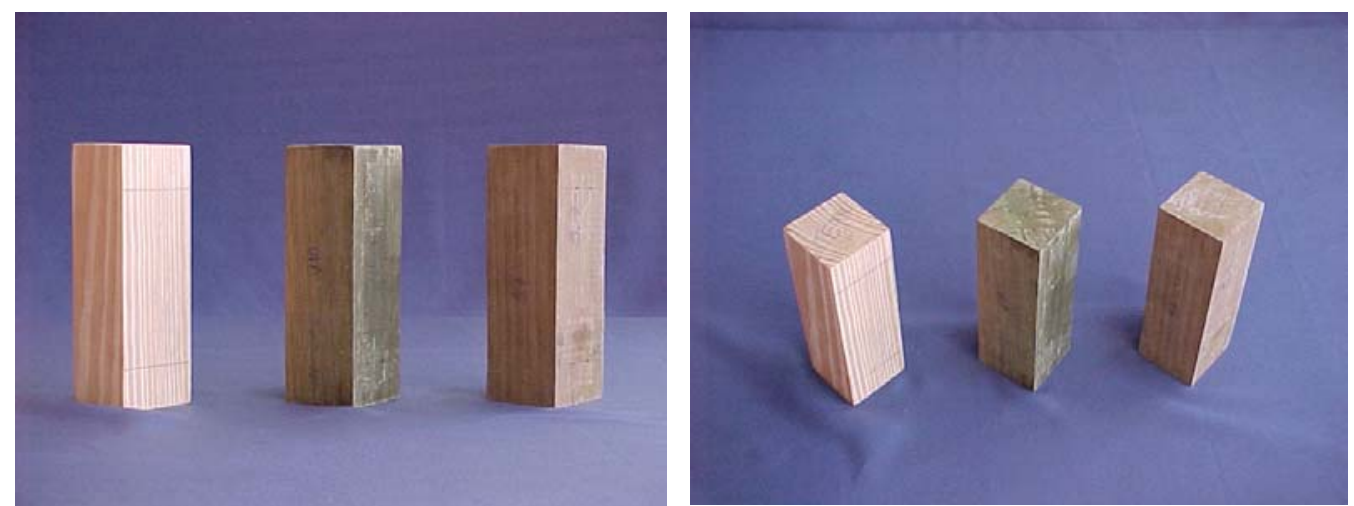

FIGURA 09 - CP's de compressão paralela às fibras

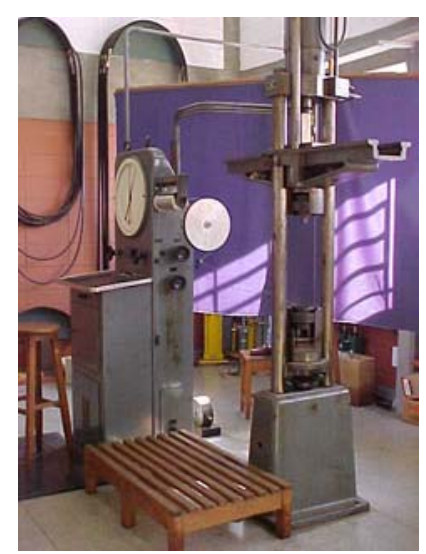

FIGURA 10 -Equipamento de ensaio - compressão paralela às fibras 


\section{b) Cisalhamento paralelo às fibras}

$\mathrm{O}$ método de ensaio ao cisalhamento paralelo às fibras e os CP's usados nesta pesquisa, estão de acordo com a NBR 7190/97-Anexo B-item 12. Nas figuras 11 e 12, estão expostos os CP's e o equipamento de ensaio utilizado, respectivamente.
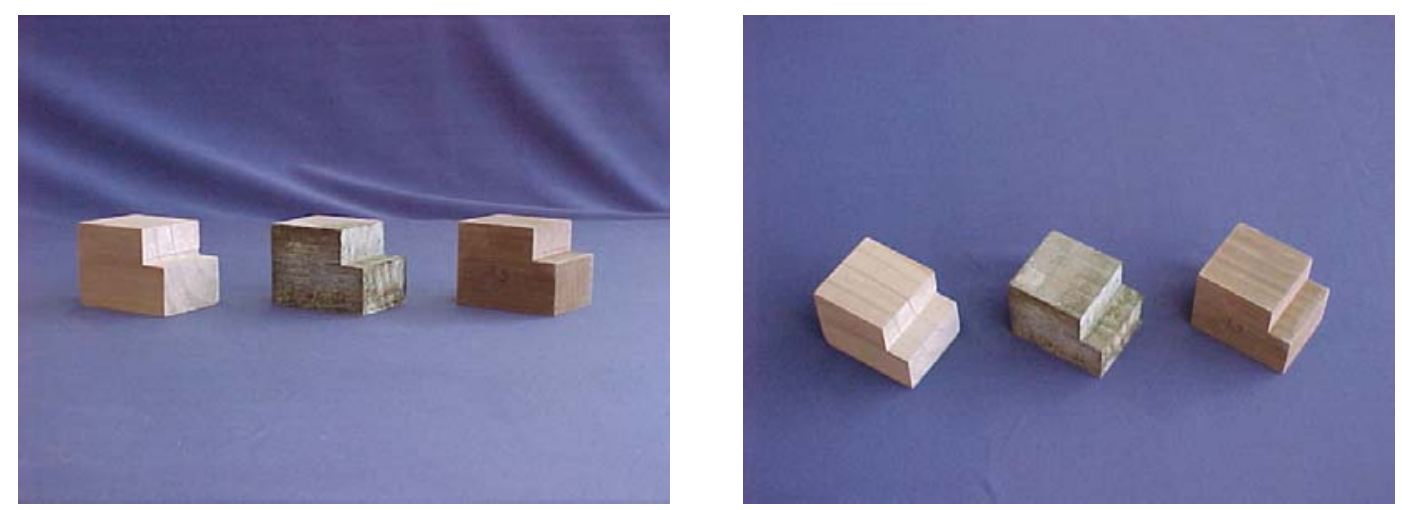

FIGURA 11 - CP's de cisalhamento paralelo às fibras

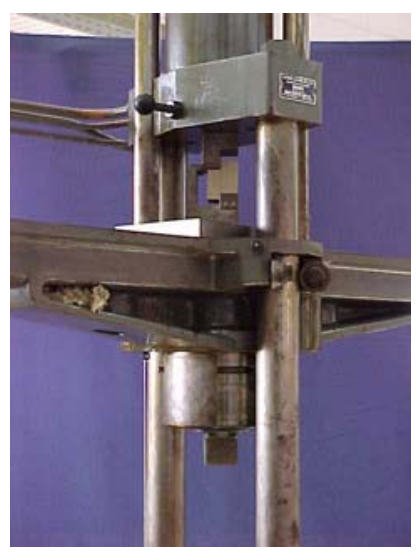

FIGURA 12 -Equipamento de ensaio - cisalhamento paralelo às fibras

\section{c) Tração paralela às fibras}

Do método de ensaio à tração paralela às fibras, foram obtidos resultados de resistência à tração paralela às fibras $\left(\mathrm{f}_{\mathrm{t} 0}\right)$.
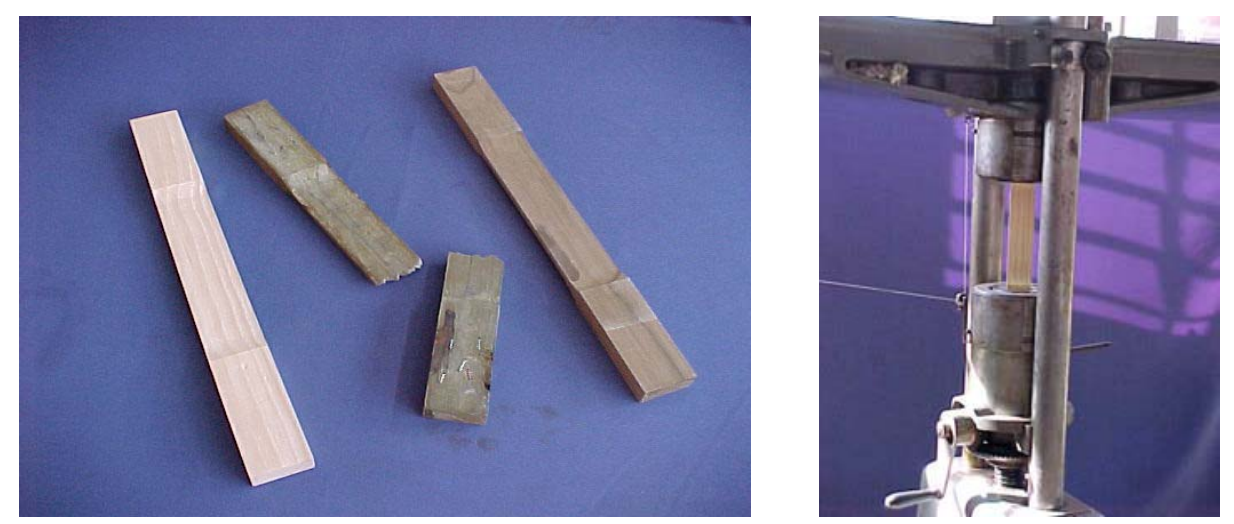
FIGURA 13 - CP's e equipamento de ensaio - tração paralela às fibras

\subsubsection{Processo de preservação}

A preservação dos CP's foi realizada com os produtos CCA e CCB através do Processo de Burnett (célula cheia). Informações a respeito deste processo e de procedimentos correlatos, encontram-se registradas com detalhes nas normas brasileiras NBR 6229 - "Postes de Eucalipto preservados sob pressão" e EB-474 "Moirões de madeira preservada para cercas". Este processo também é descrito detalhadamente por LEPAGE et al. (1986).

\subsubsection{Procedimento experimental}

Este item está apresentado com o intuito de detalhar as fases da parte experimental da pesquisa, desde a confecção dos CP's, passando pelos processos de preservação e, finalmente, explicitando a relação entre as propriedades mecânicas das citadas espécies.

\subsubsection{Fase preliminar}

Devido à variabilidade das propriedades da madeira, fez-se necessária a realização de alguns ensaios preliminares, cujo objetivo principal foi comprovar a não variação, no sentido axial, das propriedades de compressão paralela às fibras (resistência e elasticidade) da peça de madeira, uma vez fixada a posição ao longo do raio.

Os ensaios acima mencionados foram realizados de acordo com as prescrições contidas na NBR 7190/97 - Anexo “B”. As espécies utilizadas, bem como as respectivas quantidades de CP's, estão citadas a seguir: Pinus (Pinus spp) 20 CP's, retirados de cinco peças; Eucalipto Grandis (Eucalyptus grandis) - 10 CP's, retirados de duas peças; Garapa (Apuleia leiocarpa) - quatro CP's, retirados de uma peça; Pau-amarelo (Euxylophora paraensis) - quatro CP's, retirados de uma peça. A figura 14 ilustra a seqüência de retirada dos CP's gêmeos.

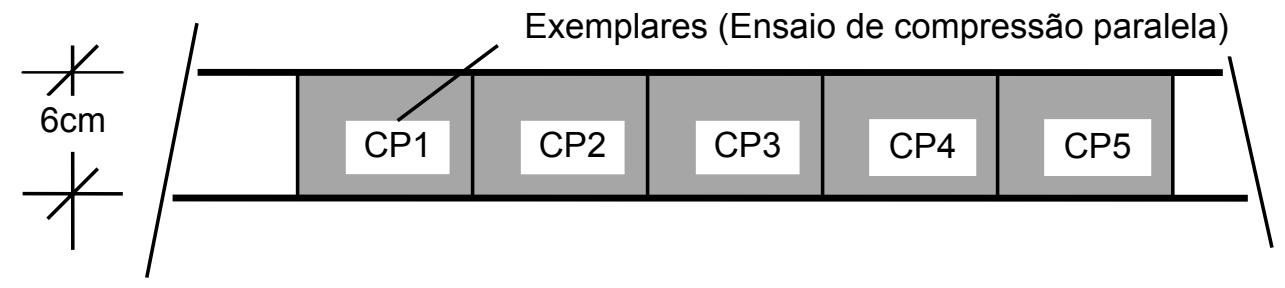


FIGURA 14 - Gabarito de obtenção dos CP's da fase preliminar

O resultado desta fase pode ser explicado a partir de análises estatísticas, através da distribuição " $t$ " de Student. Os resultados (ver Capítulo 4) foram referidos a um intervalo de confiança de 95\%. Nestas condições, a invariabilidade da resistência evidencia que outros parâmetros considerados ao longo de cada fase do trabalho são responsáveis pela variação detectada.

\subsubsection{Fase principal}

Para alcançar o objetivo principal da pesquisa, a fase principal enfatizou mais especificamente as propriedades mecânicas (resistência e rigidez), as quais podem ser consideradas de maior relevância para o projeto de estruturas de madeira. Assim sendo, conforme as prescrições da NBR 7190/97 - Item 6.3, tais propriedades podem ser determinadas através das caracterizações completa, mínima e simplificada.

Levando em consideração os objetivos do trabalho, foi feita a opção pela determinação das propriedades de resistência na compressão, tração e cisalhamento paralelo às fibras, abrangidas pela chamada caracterização mínima da madeira.

Nesta fase foram propostos e concluídos os ensaios de CP's sem preservação (amostra padrão) e preservados, com o propósito de comparar e avaliar a influência do processo de preservação e do produto químico nas propriedades de resistência e rigidez à compressão e de resistência à tração e ao cisalhamento paralelo às fibras. De posse dos resultados individuais de cada tipo de ensaio, propôs-se também algumas relações entre os valores das resistências características à compressão e ao cisalhamento paralelo, bem como entre à compressão e à tração paralela.

De acordo com a NBR 7190/97 - Anexo B, as análises das resistências foram feitas para o valor da carga de ruptura, enquanto a rigidez foi determinada para a fase elástico-linear. Quando necessário, ambos os parâmetros sofreram correções das umidades, tomando como referência valores iguais a 12\%. Esta correção se deu através das recomendações prescritas na NBR 7190/97 - Item 6.2 e pelas sugestões apresentadas por LOGSDON (1998), conforme mostrada a seguir.

Tal correção, relativa aos valores de resistência e de rigidez, foi realizada empregando a expressão a seguir: 


$$
X_{12 \%}=X_{U \%}\left[1+\frac{\alpha(U \%-12)}{100}\right]
$$

Sendo,

${ }^{*} \mathrm{X}_{12 \%} ; \mathrm{X}_{\mathrm{U} \%}$ : resistência ou rigidez de um $\mathrm{CP}$ a $12 \%$ e a $\mathrm{U} \%$ de umidade, respectivamente;

*U\%: umidade do CP ensaiado, em porcentagem.

* $\alpha$ : fator de correção da umidade, definido como,

$\Rightarrow$ Segundo a NBR 7190/97:

-Resistência (qualquer tipo de solicitação) - $\alpha=3,0$;

-Rigidez (qualquer tipo de solicitação) - $\alpha=2,0$.

$\Rightarrow$ Segundo LOGSDON (1998):

-Resistência à compressão paralela às fibras $\left(\mathrm{f}_{\mathrm{c} 0}\right)-\alpha=3,5$;

-Resistência à tração paralela às fibras $\left(\mathrm{f}_{\mathrm{t} 0}\right)-\alpha=2,0$;

-Resistência ao cisalhamento paralelo às fibras $\left(f_{\mathrm{v} 0}\right)-\alpha=2,5$;

-Rigidez à compressão paralela às fibras $\left(\mathrm{E}_{\mathrm{c} 0}\right)-\alpha=2,5$.

Para respaldar tal avaliação, foi verificada a retenção dos preservativos nos CP's ensaiados. Além disto, com caráter informativo e ilustrativo, foram determinados os valores da massa específica aparente para cada CP sem preservação, corrigido a $12 \%$ de umidade, utilizando o diagrama de Kollmann. No Capítulo 4, tais valores são apresentados na forma de média aritmética, obtida a partir dos CP's de cada espécie.

O estudo foi realizado a partir dos seguintes parâmetros:

a)Espécies de madeira

*Nativas - Angelim sp (Vatairea sp), Ipê (Tabebuia sp), Jatobá (Hymenaea sp) e Copaíba (Copaifera sp);

*Reflorestamento - Pinus Elliottii (Pinus elliottii) e Eucalipto Grandis (Eucalyptus grandis);

b)Processo de Preservação - Processo de Burnett (célula cheia);

c)Tipos de preservativo - CCA e CCB. 
Em uma primeira etapa, foram analisadas somente as espécies nativas. Os CP's destas referidas espécies foram obtidos de seis peças com dimensões transversais nominais medindo $(6 \times 12)$ centímetros, através da escolha aleatória em uma serraria do município de São Carlos-SP.

Para cada uma das peças, obedecendo uma seqüência no comprimento, foram confeccionados dois exemplares, contendo quatro CP's no total (ver figura 15).
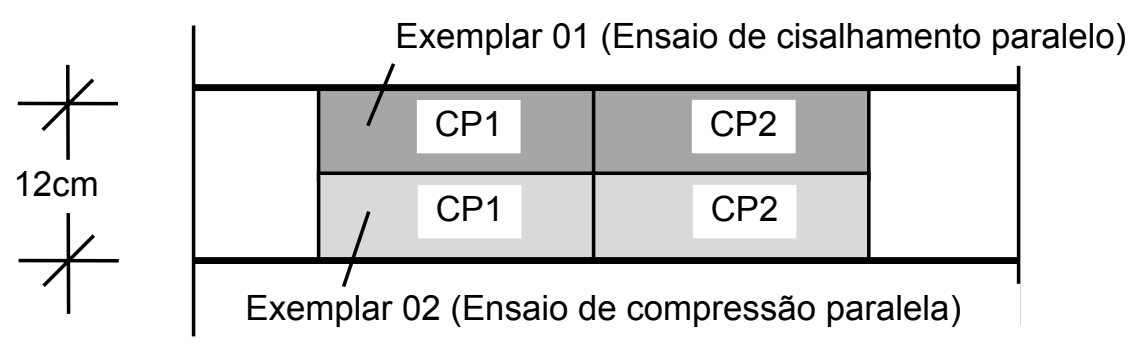

FIGURA 15 - Gabarito de obtenção dos CP's da fase final (1 $1^{\underline{a}}$ etapa)

Cada exemplar é composto por dois CP's e destinados aos ensaios de cisalhamento e de compressão paralela às fibras. Conforme este procedimento, obteve-se uma amostragem contendo 24 CP's por espécie e, finalmente um total de 96 CP's. Para cada espécie, 12 CP's (seis de compressão e seis de cisalhamento) foram ensaiados sem tratamento preservativo. A impregnação foi realizada em dois CP's de cada peça (um de cada exemplar), utilizando preservativo do tipo CCA.

Através das recomendações dadas pelas normas NBR-6229 e EB-474, foi preparada uma solução contendo um kilograma de soluto na forma de pasta e 20 litros de água, obtendo uma concentração de $50 \mathrm{~g} / \mathrm{L}$. A preservação foi realizada na usina do SET/LaMEM e ocorreu em duas fases: na primeira houve a aplicação de um vácuo de $400 \mathrm{mmHg}$ por aproximadamente uma hora; na segunda fase foi aplicada uma pressão de $110 \mathrm{~N} / \mathrm{cm}^{2}$ durante 90 minutos. Este procedimento replica adequadamente os procedimentos empregados nas usinas industriais.

Na tabela 05 é apresentada de maneira resumida o quantitativo de ensaios. 
TABELA 05 - Ensaios realizados na primeira etapa - espécies nativas

\begin{tabular}{|c|c|c|c|c|c|c|}
\hline \multirow[t]{2}{*}{ Espécie } & \multirow{2}{*}{$\begin{array}{c}\text { Classe de } \\
\text { Resistência }\end{array}$} & \multicolumn{2}{|c|}{$\begin{array}{c}\text { Amostra Padrão } \\
\text { (no de CP's) }\end{array}$} & \multicolumn{2}{|c|}{$\begin{array}{c}\text { Amostra Preservada (CCA) } \\
\left(\mathrm{n}^{\mathrm{0}} \text { de CP's) }\right.\end{array}$} & \multirow[t]{2}{*}{ Total } \\
\hline & & Cisalham. & Compressão & Cisalham. & Compressão & \\
\hline Angelim & C-40 & 06 & 06 & 06 & 06 & 24 \\
\hline Copaíba & C-60 & 06 & 06 & 06 & 06 & 24 \\
\hline Ipê & C-60 & 06 & 06 & 06 & 06 & 24 \\
\hline Jatobá & C-60 & 06 & 06 & 06 & 06 & 24 \\
\hline & & 24 & 24 & 24 & 24 & 96 \\
\hline
\end{tabular}

Na segunda etapa, foi decidido pela utilização da madeira de Pinus Elliottii e de Eucalipto Grandis para a impregnação com os preservativos CCA e CCB.

Nesta etapa, os CP's de Eucalipto Grandis foram obtidos a partir de 18 peças de dois lotes distintos, sendo seis do primeiro (amostra 01) e 12 do segundo lote (amostra 02). A escolha das peças ocorreu de maneira a possibilitar a retirada dos CP's da região do alburno (parte mais impregnável).

A amostra 01 foi composta por dois exemplares com dois CP's obtida de cada peça, totalizando 24 unidades. Para a amostra 02, foram confeccionados dois exemplares com três CP's cada, totalizando 72 unidades. Desta forma, a metade de cada amostra foi destinado a um tipo de ensaio, isto é, cisalhamento e compressão paralela às fibras. Os CP's de cada exemplar da amostra 01 foram ensaiados sem tratamento preservativo e preservados com produto hidrossolúvel tipo CCA. A mostra 02 , por sua vez, foi submetida à ensaios com CP's naturais e preservados com CCA e CCB.

De maneira análoga a anterior, foram escolhidas 32 peças para a confecção dos CP's da madeira de Pinus Elliottii. A partir destas peças, foram compostos os seguintes conjuntos (contendo três CP's cada):

*64 exemplares, sendo 32 destinados aos ensaios compressão e o restante aos ensaios de cisalhamento paralelo às fibras;

*12 exemplares destinados aos ensaios tração paralela às fibras.

Portanto, para os exemplares de compressão e cisalhamento, foram ensaiados 32 CP's sem tratamento preservativo e os demais preservados com produto hidrossolúvel tipo CCA e CCB. Para o exemplar de tração foram ensaiados 12 CP's sem tratamento preservativo e o restante preservado com produto hidrossolúvel tipo CCA e CCB. 
A preservação com o produto CCA foi realizada de maneira análoga à primeira etapa da fase final (CP's das espécies nativas). Enquanto a impregnação com CCB foi realizada pela empresa PREMA - PRESERVAÇÃO DE MADEIRA LTDA.

Como conseqüência das condições expostas na citada etapa, o desenvolvimento do trabalho encontra-se resumidamente nas tabelas 06 e 07.

TABELA 06 - Ensaios realizados na segunda etapa - Pinus Elliottii

\begin{tabular}{|c|c|c|c|c|c|c|c|c|c|c|c|}
\hline Espécie & $\begin{array}{c}\text { Classe } \\
\text { de } \\
\text { Resistência }\end{array}$ & \multicolumn{3}{|c|}{$\begin{array}{c}\text { Amostra Padrão } \\
\left(n^{0} \text { de CP's) }\right.\end{array}$} & \multicolumn{3}{|c|}{$\begin{array}{c}\text { Amostra Preservada } \\
\text { (CCA) } \\
\text { (no }{ }^{\circ} \text { de CP's) }\end{array}$} & \multicolumn{3}{|c|}{$\begin{array}{c}\text { Amostra Preservada } \\
\text { (CCB) } \\
\text { (no }{ }^{\circ} \text { de CP's) } \\
\end{array}$} & Total \\
\hline \multirow{2}{*}{$\begin{array}{l}\text { Pinus } \\
\text { Elliotti }\end{array}$} & \multirow{2}{*}{ C-30 } & Cis & $\mathrm{C}$ & $\mathbf{T}$ & Cis & $\mathrm{C}$ & $\mathbf{T}$ & Cis & $\mathbf{C}$ & $\mathbf{T}$ & \multirow{2}{*}{228} \\
\hline & & 32 & 32 & 12 & 32 & 32 & 12 & 32 & 32 & 12 & \\
\hline
\end{tabular}

TABELA 07 - Ensaios realizados na segunda etapa - Eucalipto Grandis

\begin{tabular}{|c|c|c|c|c|c|c|c|c|}
\hline \multirow[t]{2}{*}{ Amostras } & \multirow{2}{*}{$\begin{array}{c}\text { Classe } \\
\text { de } \\
\text { Resistência }\end{array}$} & \multicolumn{2}{|c|}{$\begin{array}{c}\text { Amostra Padrão } \\
\text { (no de CP's) }\end{array}$} & \multicolumn{2}{|c|}{$\begin{array}{c}\text { Amostra } \\
\text { Preservada (CCA) } \\
\left(n^{0} \text { de CP's }\right)\end{array}$} & \multicolumn{2}{|c|}{$\begin{array}{c}\text { Amostra Preservada } \\
\text { (CCB) } \\
\left(n^{0} \text { de CP's }\right)\end{array}$} & \multirow[t]{2}{*}{ Total } \\
\hline & & Cis & $\mathrm{C}$ & Cis & $\mathbf{C}$ & Cis & $\mathbf{C}$ & \\
\hline 01 & C-40 & 06 & 06 & 06 & 06 & ----- & ------ & 24 \\
\hline 02 & C-60 & 12 & 12 & 12 & 12 & 12 & 12 & 72 \\
\hline & & 18 & 18 & 18 & 18 & 18 & 18 & 96 \\
\hline
\end{tabular}

Onde,

*Cis: cisalhamento paralelo às fibras;

${ }^{*} \mathrm{C}$ : compressão paralela às fibras;

*T: tração paralela às fibras.

Vale ressaltar que, os CP's utilizados foram confeccionados pelos funcionários do Laboratório de Madeiras e Estruturas de Madeira, pertencente ao Departamento de Engenharia de Estruturas de Estruturas da Escola de Engenharia de São Carlos da Universidade de São Paulo (LaMEM/SET/EESC/USP).

Com o término dos ensaios da última fase, foram imediatamente determinados os teores de umidade dos referidos CP's e, em seguida, obtiveram-se os valores da massa específica aparente da amostra padrão a $12 \%$ de umidade, através da correção fornecida pelo diagrama de Kollmann. Além disto, foram verificadas as retenções dos preservativos (CCA e CCB).

Portanto, finalizando a pesquisa, os resultados da fase experimental foram apresentados (ver a seguir, Capítulo 4) dando ênfase nos seguinte tópicos: 
*relações entre os valores das resistências de ruptura à compressão, tração e ao cisalhamento paralelo às fibras das amostras preservadas (CCA e CCB) e da amostra padrão (sem preservação);

*relação entre os valores médios da rigidez à compressão paralela às fibras das amostras preservadas (CCA e CCB) e da amostra padrão (sem preservação);

*relação entre os valores das resistências característica à compressão e ao cisalhamento paralelo às fibras da amostra padrão (sem preservação);

*relação entre os valores das resistências característica à compressão e ao cisalhamento paralelo às fibras das amostras preservadas com CCA e CCB;

*relação entre os valores das resistências característica à compressão e à tração paralela às fibras da amostra padrão (sem preservação);

*relação entre os valores das resistências característica à compressão e à tração paralela às fibras das amostras preservadas com CCA e CCB.

Como resultado, no Capítulo 4 foi quantificado a influência do método de impregnação sob vácuo/pressão e dos preservativos químicos nas propriedades mecânicas (resistência e elasticidade) da madeira. Além disto, também foi apresentado algumas relações entre valores característicos de resistência.

\subsection{Análise estatística}

Com o intuito de representar suscintamente os resultados obtidos experimentalmente, foram empregadas algumas análises estatísticas como artifício básico. Tais análises foram expressas através da distribuição "t" de Student, da regressão linear simples e dos conceitos básicos da distribuição de Gauss (distribuição normal), ou seja, média aritmética, desvio padrão e coeficiente de variação. Estas aplicações estatísticas foram discutidas por FUSCO (1976) e MEYER (1983).

$\mathrm{Na}$ fase preliminar da pesquisa, em decorrência da quantidade de CP's considerados, ficou caracterizada uma distribuição de pequenas amostras, por isso foi utilizada a distribuição " $\mathrm{t}$ ” de Student. O objetivo principal desta distribuição foi dar o respaldo necessário para, através da determinação do Intervalo de confiança da média $\left(\mu_{x}\right)$, mostrar a invariabilidade estatística da amostra, quanto a resistência à compressão paralela às fibras. 
$\mathrm{Na}$ fase seguinte, ou seja, fase final, foram realizadas algumas comparações entre os valores de resistência e de rigidez obtidos para as amostras padrão (sem preservação) e preservadas. Além disto, no que diz respeito à rigidez, comparou-se também os resultados obtidos através da recomendação da NBR 7190/97 com os valores da regressão linear simples, usando um aplicativo de planilha eletrônica. Tais relações foram expressas através do emprego dos conceitos básicos da estatística, ou seja, média aritmética, desvio padrão e coeficiente de variação. A validade estatística das citadas relações foi dada através da utilização do Teste dos Dados Pareados (Pairing) e o Teste dos Desvios. A análise conjunta de ambos testes, empregada por ROCCO LAHR (1983) e LOGSDON (1998), permite a comparação entre conjunto de dados emparelhados, verificando-se se a média dos desvios (diferença entre valores correspondentes que compõem os conjuntos de dados) poderá ser nula. Em outras palavras, estes testes permitem decidir se os dados de dois conjuntos distintos podem ser considerados estatisticamente equivalentes.

Cabe ressaltar que, todas as comparações, sejam da resistência ou rigidez, foram realizadas a partir da correção dos valores da umidade para 12\%, empregando as recomendações da NBR 7190/97, bem como as sugestões apresentadas por LOGSDON (1998). 


\section{CAPÍTULO 4: RESULTADOS E DISCUSSÕES}

Neste capítulo são apresentados e discutidos os resultados obtidos a partir da metodologia exposta no Capítulo 3, divididos em duas fases, preliminar e principal.

\subsection{Fase preliminar}

Os resultados aqui apresentados têm o intuito de verificar a variação das propriedades de resistência e de elasticidade ao longo do comprimento da peça, mantendo fixa a posição no raio. Nesta condição, segundo a abordagem da NBR 7190/97, os CP's são denominados por corpos-de-prova gêmeos. A partir da realização dos ensaios foram obtidos os seguintes resultados:

TABELA 08 - Valores das propriedades de resistência e rigidez - coníferas

\begin{tabular}{|c|c|c|c|c|}
\hline Espécie & Peça & $\begin{array}{c}\text { Corpos de } \\
\text { Prova }\end{array}$ & $\begin{array}{c}\text { Resistência à compressão } \\
\text { paralela às fibras }\left(\mathbf{f}_{\mathrm{c} 0, \mathrm{i}}\right) \\
(\mathrm{MPa})\end{array}$ & $\begin{array}{l}\text { Módulo de Elasticidade à compressão } \\
\text { paralela às fibras }\left(\mathbf{E}_{\mathrm{c} 0, \mathrm{i}}\right) \\
(\mathrm{MPa})\end{array}$ \\
\hline \multirow{4}{*}{ Pinus } & \multirow{4}{*}{01} & 01 & 34,0 & 8133 \\
\hline & & 02 & 31,7 & 8762 \\
\hline & & 03 & 33,2 & 7668 \\
\hline & & 04 & 35,7 & 9422 \\
\hline \multirow{4}{*}{ Pinus } & \multirow{4}{*}{02} & 01 & 28,8 & 14773 \\
\hline & & 02 & 29,7 & 13164 \\
\hline & & 03 & 28,5 & 12551 \\
\hline & & 04 & 29,6 & 13446 \\
\hline \multirow{4}{*}{ Pinus } & \multirow{4}{*}{03} & 01 & 38,6 & 8596 \\
\hline & & 02 & 38,3 & 9351 \\
\hline & & 03 & 37,9 & 8963 \\
\hline & & 04 & 36,9 & 9876 \\
\hline \multirow{4}{*}{ Pinus } & \multirow{4}{*}{04} & 01 & 42,4 & 10868 \\
\hline & & 02 & 38,6 & 10299 \\
\hline & & 03 & 37,2 & 10168 \\
\hline & & 04 & 38,2 & 10384 \\
\hline \multirow{4}{*}{ Pinus } & \multirow{4}{*}{05} & 01 & 51,5 & -------- \\
\hline & & 02 & 52,6 & -------- \\
\hline & & 03 & 50,3 & -------- \\
\hline & & 04 & 54,1 & -------- \\
\hline
\end{tabular}

Na Tabela 08, para a peça 05, pode-se notar a ausência de valores para o módulo de elasticidade longitudinal (rigidez). Tal fato, foi conseqüência de 
problemas detectados no relógio comparador durante a realização do ensaio. Desta forma, os dados obtidos para as deformações foram desconsiderados.

TABELA 09 - Valores das propriedades de resistência e rigidez - Dicotiledôneas

\begin{tabular}{|c|c|c|c|c|}
\hline Espécies & Peça & $\begin{array}{c}\text { Corpos } \\
\text { de } \\
\text { Prova } \\
\end{array}$ & $\begin{array}{c}\text { Resistência à compressão } \\
\text { paralela às fibras }\left(\mathbf{f}_{\mathrm{c} 0, \mathrm{i}}\right) \\
(\mathrm{MPa}) \\
\end{array}$ & $\begin{array}{c}\text { Módulo de Elasticidade à compressão } \\
\text { paralela às fibras }\left(\mathrm{E}_{\mathrm{c} 0, \mathrm{i}}\right) \\
(\mathrm{MPa})\end{array}$ \\
\hline \multirow{5}{*}{ E. Grandis } & \multirow{5}{*}{01} & 01 & 65,7 & 20154 \\
\hline & & 02 & 61,1 & 22190 \\
\hline & & 03 & 66,7 & 17796 \\
\hline & & 04 & 62,0 & 19850 \\
\hline & & 05 & 58,4 & 16526 \\
\hline \multirow{5}{*}{ E. Grandis } & \multirow{5}{*}{02} & 01 & 68,6 & 25041 \\
\hline & & 02 & 70,0 & 21427 \\
\hline & & 03 & 73,7 & 26605 \\
\hline & & 04 & 68,3 & 21025 \\
\hline & & 05 & 71,6 & 20689 \\
\hline \multirow{4}{*}{ Garapa } & \multirow{4}{*}{01} & 01 & 68,3 & 14303 \\
\hline & & 02 & 68,6 & 13617 \\
\hline & & 03 & 68,0 & 14297 \\
\hline & & 04 & 69,1 & 13876 \\
\hline \multirow{4}{*}{ Pau-Amarelo } & \multirow{4}{*}{01} & 01 & 63,3 & --------- \\
\hline & & 02 & 63,4 & --------- \\
\hline & & 03 & 62,7 & --------- \\
\hline & & 04 & 63,5 & --------- \\
\hline
\end{tabular}

A Tabela 09 não apresenta valores para o módulo de elasticidade longitudinal para a espécie "Pau-amarelo". O motivo desta ausência é o mesmo apresentado para a peça 05 de Pinus (Tabela 08). Da mesma forma, os dados das deformações foram desconsiderados.

Segundo FUSCO (1976), para pequenas amostras (quantidade não superior a 30 exemplares), a verificação da variabilidade dos resultados experimentais pode ser dada a partir de análises estatísticas, através da distribuição " $t$ " de Student. Conforme o mesmo autor, desde que a amostra considerada tenha no mínimo quatro ou cinco exemplares, tal análise poderá ser quantificada através da condição probabilística, definida como Intervalo de confiança da média $\left(\mu_{\mathrm{x}}\right)$, mostrada na expressão 4.1,

$$
x_{m}-t(95 \%) \frac{s_{d}}{\sqrt{n}} \leq \mu_{x} \leq x_{m}+t(95 \%) \frac{s_{d}}{\sqrt{n}}
$$

Onde,

$* \mu_{\mathrm{x}}$ : média dos desvios;

*t(95\%): coeficiente da Distribuição " $t$ ”, para um valor de 95\% de confiança;

* $\mathrm{x}_{\mathrm{m}}$ : valor médio da amostra; 
${ }^{*} \mathrm{~S}_{\mathrm{d}}$ : desvio-padrão da amostra;

*n: número de corpos-de-prova da amostra.

Esta expressão substitui, para pequenas amostras, a função desempenhada pela distribuição de Gauss (distribuição normal) com grandes amostras.

A utilização da condição expressa em 02 foi possível a partir dos coeficientes t(95\%) apresentados por MEYER (1983). Portanto, com os resultados expressos nas Tabelas 08 e 09 e baseado na referida equação, obtém-se os valores apresentados na tabela a seguir.

TABELA 10 - Parâmetros estatísticos

\begin{tabular}{|c|c|c|c|c|c|c|c|c|}
\hline \multirow[t]{2}{*}{ Espécies } & \multicolumn{4}{|c|}{$\begin{array}{c}\text { Resistência à compressão paralela às fibras } \\
\left(\mathbf{f}_{\mathbf{c} 0)}\right) \\
(\mathrm{MPa})\end{array}$} & \multicolumn{4}{|c|}{$\begin{array}{c}\text { Módulo de elasticidade à compressão } \\
\text { paralela às fibras }\left(\mathrm{E}_{\mathrm{c} 0}\right) \\
(\mathrm{MPa}) \\
\end{array}$} \\
\hline & $\mathbf{X}_{\mathrm{m}}$ & $\mathbf{S}_{\mathrm{d}}$ & $\mathbf{X}_{\text {inf }}$ & $\mathbf{X}_{\text {sup }}$ & $\mathbf{X}_{\mathrm{m}}$ & $\mathbf{s}_{\mathrm{d}}$ & $\mathbf{X}_{\mathrm{inf}}$ & $\mathbf{X}_{\text {sup }}$ \\
\hline Pinus (1) & 33,7 & 1,7 & 31,0 & 36,3 & 8496 & 763 & 7282 & 9710 \\
\hline Pinus (2) & 29,2 & 0,6 & 28,2 & 30,1 & 13485 & 937 & 11994 & 14976 \\
\hline Pinus (3) & 37,9 & 0,7 & 36,8 & 39,1 & 9196 & 548 & 8324 & 10068 \\
\hline Pinus (4) & 39,1 & 2,3 & 35,5 & 42,7 & 10430 & 305 & 9944 & 10915 \\
\hline Pinus (5) & 52,1 & 1,6 & 49,5 & 54,7 & ------- & ------- & ------- & ------- \\
\hline E. Grandis (1) & 62,8 & 3,4 & 58,6 & 67,0 & 19303 & 2199 & 16573 & 22033 \\
\hline E. Grandis (2) & 70,5 & 2,3 & 67,7 & 73,2 & 22957 & 2687 & 19622 & 26292 \\
\hline Garapa & 68,5 & 0,5 & 67,8 & 69,3 & 14023 & 337 & 13487 & 14559 \\
\hline Pau-amarelo & 63,3 & 0,4 & 62,8 & 63,8 & ------- & ------- & ------- & ------- \\
\hline
\end{tabular}

Com base nos resultados apresentados na Tabela 10, foi observado que em todas as peças ensaiadas, seja na resistência ou rigidez, os valores individuais obtidos nos ensaios estão contidos no intervalo de confiança da média. Por isto, foi possível considerar a invariabilidade de ambas propriedades, referente a compressão paralela às fibras da madeira.

Portanto, poderá ser verificada com maior precisão, na fase principal, a influência do preservativo e do processo de preservação nas propriedades mecânicas da madeira.

\subsection{Fase principal}

Esta fase tem como objetivo principal relacionar, para as espécies de madeira mencionadas no Capítulo 3, os valores característicos das resistências à compressão, à tração e ao cisalhamento paralelo às fibras, bem como os valores médios das rigidezes à compressão paralela às fibras. Para tanto, os CP's foram considerados em 
seu estado natural (sem preservação) e sob efeitos dos preservativos químicos, tipo CCA e CCB.

A obtenção dos valores das grandezas mecânicas mencionados anteriormente foi realizada através de ensaios conforme as prescrições da NBR 7190/97 - Anexo B. De acordo com os resultados, foram estimadas as classes de resistência das espécies estudadas, através da expressão apresentada no item B.3 da mesma norma.

Com caráter informativo, foi determinada a massa específica aparente para as amostras naturais, através do Diagrama de Kollmann (ver Figura 16).

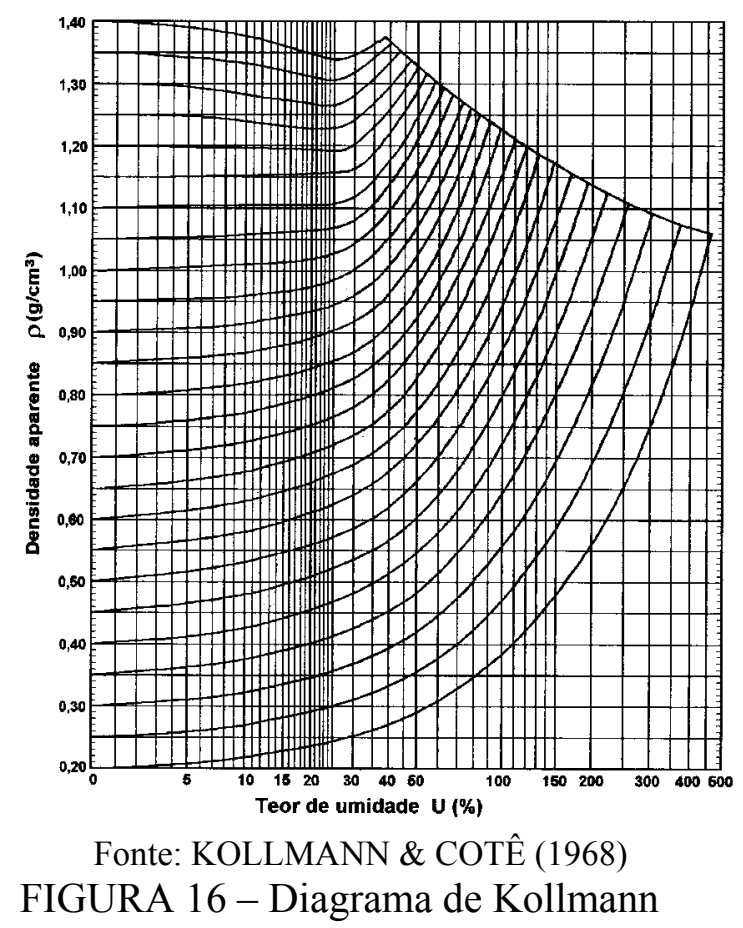

\subsubsection{Espécies nativas}

$\mathrm{Na}$ primeira etapa da fase principal, optou-se pela escolha das seguintes espécies nativas: Angelim (Vatairea $s p$ ), Ipê (Tabebuia $s p$ ), Copaíba (Copaifera $s p$ ) e Jatobá (Hymenaea sp).

A preservação, com CCA, dos CP's das referidas espécies, foi concluída em duas etapas, sendo a primeira responsável pela impregnação de 24 CP's de compressão paralela e a última pelo tratamento de 24 CP's de cisalhamento paralelo às fibras. Como resultado, foram obtidas retenções médias iguais a 10,5 kg/m $\mathrm{m}^{3}$ e 10,2 $\mathrm{kg} / \mathrm{m}^{3}$, respectivamente.

\subsubsection{Angelim (Vatairea $s p)$}


Para os CP's sem preservação com teor de umidade média em torno de $13,1 \%$, foram realizados ensaios de compressão paralela às fibras, obtendo-se valores de resistência característica iguais a $48,8 \mathrm{MPa}$ e $50,7 \mathrm{MPa}$, com correção da umidade segundo NBR 7190/97 e LOGSDON (1998), respectivamente. Desta forma, foi possível verificar um acréscimo de aproximadamente 3,8\%. Em contrapartida, foram obtidos valores iguais a 47,4MPa e 49,0MPa para os CP's preservados, provocando um acréscimo em torno de 3,2\% devido a correção sugerida por LOGSDON (1998). Neste caso a umidade atingida foi de 13,5\%. Portanto, todos os casos são classificados como classe de resistência C-40.

Também foi possível verificar, para ambas formas de correção da umidade, uma ligeira redução entre os valores das resistências características dos CP's naturais e preservados. Para a correção segundo a NBR 7190/97, os CP's preservados sofreram um decréscimo em torno de $2,8 \%$, enquanto através da correção proposta por LOGSDON (1998) tal redução atingiu 3,4\%.

No que diz respeito aos CP's sem preservação, com umidade média de $13,4 \%$, submetidos aos ensaios de cisalhamento paralelo, foram obtidos os seguintes valores de resistência: 10,1MPa (NBR 7190/97) e 9,9MPa (LOGSDON (1998)). A proposta de LOGSDON (1998) levou a uma redução de 2,3\%. Para os CP's preservados foram obtidos valores iguais a $8,4 \mathrm{MPa}$ e $8,7 \mathrm{MPa}$, provocando um decréscimo de 3,3\% dado por LOGSDON (1998). Neste caso, a umidade de ensaio foi de $13,7 \%$.

Foi observado que para a correção segundo a NBR 7190/97, a resistência característica ao cisalhamento dos CP's preservados reduziu de aproximadamente $14,2 \%$, enquanto através da correção proposta por LOGSDON (1998) tal redução atingiu $15,2 \%$.

Na Tabela 11 são apresentados resumidamente os valores discutidos acima.

TABELA 11 - Resistência característica à compressão paralela e ao cisalhamento paralelo - Angelim

\begin{tabular}{|c|c|c|c|c|c|c|c|}
\hline \multicolumn{4}{|c|}{ Resistência à compressão paralela } & \multicolumn{4}{|c|}{ Resistência ao cisalhamento paralelo } \\
\hline \multicolumn{2}{|c|}{ NBR 7190/97 } & \multicolumn{2}{|c|}{ LOGSDON (1998) } & \multicolumn{2}{|c|}{ NBR 7190/97 } & \multicolumn{2}{|c|}{ LOGSDON (1998) } \\
\hline $\begin{array}{c}\mathbf{f}_{\mathrm{c} 0, \mathrm{k}, \mathrm{p}} \\
(\mathrm{MPa})\end{array}$ & $\begin{array}{l}\mathbf{f}_{\mathrm{c} 0, \mathrm{k}, \mathrm{CCA}} \\
\text { (MPa) }\end{array}$ & $\begin{array}{c}\mathbf{f}_{\mathrm{c} 0, \mathrm{k}, \mathrm{p}} \\
(\mathrm{MPa})\end{array}$ & $\begin{array}{c}\mathbf{f}_{\mathrm{c} 0, \mathrm{k}, \mathrm{CCA}} \\
(\mathrm{MPa})\end{array}$ & $\begin{array}{c}\mathbf{f}_{\mathrm{v} 0, \mathrm{k}, \mathrm{p}} \\
(\mathrm{MPa})\end{array}$ & $\begin{array}{c}f_{\mathrm{v} 0, \mathrm{k}, \mathrm{CCA}} \\
\text { (MPa) }\end{array}$ & $\begin{array}{c}\mathbf{f}_{\mathrm{v} 0, \mathrm{k}, \mathrm{p}} \\
(\mathrm{MPa})\end{array}$ & $\begin{array}{l}\mathbf{f}_{\mathrm{v} 0, \mathrm{k}, \mathrm{CCA}} \\
(\mathrm{MPa})\end{array}$ \\
\hline 48,8 & 47,4 & 50,7 & 49,0 & 10,1 & 8,7 & 9,9 & 8,4 \\
\hline
\end{tabular}


Os valores característicos apresentados na tabela anterior foram calculados a partir dos resultados de cada CP ensaiado (ver a seguir, Tabela 12), cujo valor médio da massa específica aparente $\left(\rho_{12} \%\right)$ é de $0,79 \mathrm{~g} / \mathrm{cm}^{3}$, sendo cada valor individual corrigido para a umidade de $12 \%$, utilizando-se para tal o diagrama de Kollmann.

TABELA 12 - Valores individuais de resistência à compressão paralela e ao cisalhamento paralelo - Angelim

\begin{tabular}{|c|c|c|c|c|c|c|c|c|}
\hline \multirow{3}{*}{$\mathbf{C P}$} & \multicolumn{4}{|c|}{ Resistência à compressão paralela } & \multicolumn{4}{|c|}{ Resistência ao cisalhamento paralelo } \\
\hline & \multicolumn{2}{|c|}{$\begin{array}{l}\text { NBR 7190/97 } \\
\text { (MPa) }\end{array}$} & \multicolumn{2}{|c|}{$\begin{array}{c}\text { LOGSDON (1998) } \\
\text { (MPa) }\end{array}$} & \multicolumn{2}{|c|}{$\begin{array}{c}\text { NBR 7190/97 } \\
\text { (MPa) }\end{array}$} & \multicolumn{2}{|c|}{$\begin{array}{c}\text { LOGSDON (1998) } \\
\text { (MPa) }\end{array}$} \\
\hline & Padrão & CCA & Padrão & CCA & Padrão & CCA & Padrão & CCA \\
\hline ANG-01 & 67,9 & 62,1 & 69,4 & 64,1 & 13,3 & 14,0 & 12,9 & 13,5 \\
\hline ANG-02 & 64,4 & 56,6 & 65,4 & 58,4 & 13,2 & 13,6 & 12,8 & 13,2 \\
\hline ANG-03 & 55,5 & 50,0 & 56,9 & 51,6 & 9,2 & 8,0 & 9,0 & 7,7 \\
\hline ANG-04 & 66,5 & 70,7 & 67,0 & 72,9 & 12,5 & 13,9 & 12,2 & 13,5 \\
\hline ANG-05 & 64,3 & 61,1 & 66,0 & 63,1 & 12,7 & 13,9 & 12,4 & 13,4 \\
\hline ANG-06 & 53,2 & 49,7 & 54,5 & 51,3 & 12,5 & 13,5 & 12,2 & 13,1 \\
\hline
\end{tabular}

Por conveniência, a média e o desvio padrão dos resultados serão expressos a partir do quociente entre eles, definido como coeficiente de variação.

Para os CP's submetidos à compressão paralela às fibras, foram determinados os valores das resistências e seus respectivos parâmetros estatísticos.

TABELA 13 - Parâmetros estatísticos para resistência à compressão paralela Angelim

\begin{tabular}{|c|c|c|c|c|c|c|c|}
\hline \multicolumn{8}{|c|}{ Método de correção da umidade } \\
\hline \multicolumn{4}{|c|}{ NBR 7190/97 } & \multicolumn{4}{|c|}{ LOGSDON (1998) } \\
\hline \multicolumn{2}{|c|}{ Padrão } & \multicolumn{2}{|c|}{ CCA } & \multicolumn{2}{|c|}{ Padrão } & \multicolumn{2}{|c|}{ CCA } \\
\hline $\mathrm{f}_{\mathrm{c} 0, \mathrm{~m}}(\mathrm{MPa})$ & CV (\%) & $\mathrm{f}_{\mathrm{c} 0, \mathrm{~m}}(\mathrm{MPa})$ & CV (\%) & $\mathrm{f}_{\mathrm{c} 0, \mathrm{~m}}(\mathrm{MPa})$ & CV (\%) & $\mathrm{f}_{\mathrm{c} 0, \mathrm{~m}}(\mathrm{MPa})$ & CV (\%) \\
\hline 62,0 & 9,8 & 58,4 & 13,7 & 63,2 & 9,6 & 60,3 & 13,7 \\
\hline
\end{tabular}

A partir dos ensaios de cisalhamento paralelo às fibras, foram determinadas as resistências e calculados os parâmetros estatísticos básicos (Tabela 14).

TABELA 14 - Parâmetros estatísticos para resistência ao cisalhamento paralelo Angelim

\begin{tabular}{c|c|c|c|c|c|c|c}
\hline \multicolumn{7}{c}{ Método de correção da umidade } \\
\hline \multicolumn{3}{c|}{ NBR 7190/97 } & \multicolumn{3}{c}{ LOGSDON (1998) } \\
\hline \multicolumn{2}{c|}{ CCAdrão } & \multicolumn{2}{c|}{ Padrão } & \multicolumn{3}{c}{ CCA } \\
\hline $\mathbf{f}_{\mathrm{v} 0, \mathrm{~m}}(\mathbf{M P a})$ & $\mathbf{C V}(\%)$ & $\mathbf{f}_{\mathrm{v} 0, \mathrm{~m}}(\mathrm{MPa})$ & $\mathbf{C V}(\%)$ & $\mathbf{f}_{\mathbf{v} 0, \mathrm{~m}}(\mathbf{M P a})$ & $\mathbf{C V}(\%)$ & $\mathbf{f}_{\mathrm{v} 0, \mathrm{~m}}(\mathbf{M P a})$ & $\mathbf{C V}(\%)$ \\
\hline 12,3 & 12,4 & 12,8 & 18,5 & 11,9 & 12,2 & 12,4 & 18,5 \\
\hline
\end{tabular}

De acordo com os resultados mostrados na Tabela 13, referente a resistência à compressão paralela às fibras, percebeu-se que, independentemente da forma de correção da umidade, a diferença entre os valores dos coeficientes de variação entre os CP's naturais e preservados foi pequena, em torno de quatro pontos percentuais. 
No que diz respeito ao cisalhamento paralelo às fibras, a Tabela 14 mostra que tal diferença foi de aproximadamente seis pontos percentuais. Portanto, sabendo que a NBR 7190/97 admite um coeficiente da variação de até $18 \%$ e $28 \%$ para as solicitações normais e tangenciais, respectivamente, pode-se concluir que, além dos possíveis problemas inerentes aos ensaios, a anisotropia do material também não influenciou de maneira relevante nos resultados.

O módulo de elasticidade longitudinal de cada CP foi obtido a partir do ensaio de compressão paralela às fibras, empregando dois procedimentos distintos. A primeira, de acordo com as prescrições contidas na NBR 7190/97 - Anexo B (Item 8) e a segunda, através de uma regressão linear simples. A segunda maneira, provavelmente revelará resultados mais precisos, pois a sua determinação se deu a partir de cinco pontos, enquanto as recomendações da NBR 7190/97 exigem apenas dois pontos. Estes resultados estão apresentados nas Tabelas 15 e 16. Como ilustração, a Figura 17 traz um exemplo do módulo de elasticidade, obtido através da regressão linear simples.

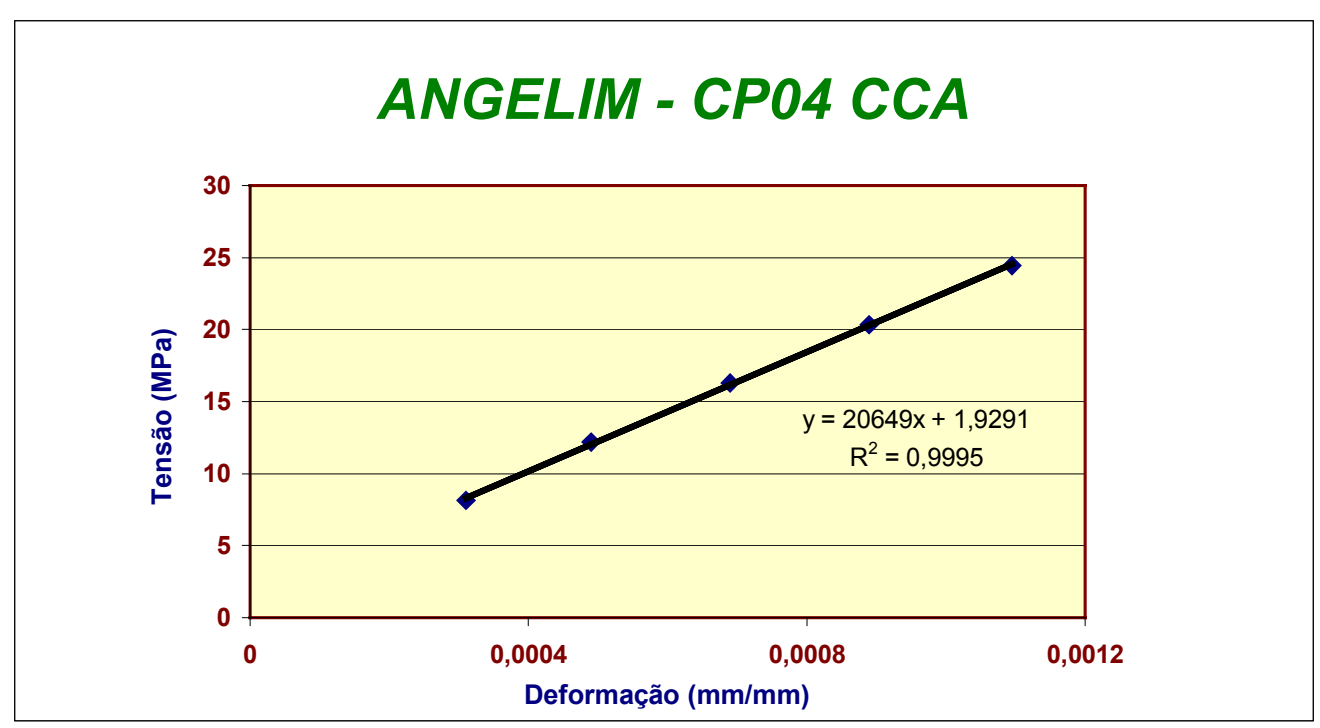

FIGURA 17 - Módulo de elasticidade longitudinal do Angelim (regressão linear simples) 
TABELA 15 - Valores individuais de rigidez à compressão paralela - NBR 7190/97 Angelim

\begin{tabular}{|c|c|c|c|c|c|c|}
\hline \multirow[b]{3}{*}{$\mathbf{C P}$} & \multicolumn{6}{|c|}{ Correção da umidade - NBR 7190/97 } \\
\hline & \multicolumn{3}{|c|}{ Padrão } & \multicolumn{3}{|c|}{$\mathbf{C C A}$} \\
\hline & $\begin{array}{l}\mathbf{E}_{\mathrm{c} 0, \mathrm{NBR}} \\
(\mathrm{MPa})\end{array}$ & $\begin{array}{l}\mathbf{E}_{\mathrm{c} 0, \mathrm{Regr}} \\
(\mathrm{MPa})\end{array}$ & $\begin{array}{c}\Delta \\
(\%)\end{array}$ & $\begin{array}{l}\mathbf{E}_{\mathrm{c} 0, \mathrm{NBR}} \\
(\mathrm{MPa})\end{array}$ & $\begin{array}{l}\mathbf{E}_{\text {c0,Regr }} \\
\text { (MPa) }\end{array}$ & $\begin{array}{c}\Delta \\
(\%)\end{array}$ \\
\hline ANG-01 & 23970 & 23902 & $-0,3$ & 26370 & 26105 & $-1,0$ \\
\hline ANG-02 & 24382 & 23452 & $-3,8$ & 23436 & 23352 & $-0,4$ \\
\hline ANG-03 & 22682 & 25159 & 10,9 & 24076 & 23953 & $-0,5$ \\
\hline ANG-04 & 18310 & 19853 & 8,4 & 18765 & 18778 & 0,1 \\
\hline ANG-05 & 24468 & 24391 & 0,3 & 23790 & 23927 & 0,6 \\
\hline ANG-06 & 19828 & 19819 & 0,0 & 22324 & 22322 & 0,0 \\
\hline
\end{tabular}

TABELA 16 - Valores individuais de rigidez à compressão paralela - LOGSDON (1998) - Angelim

\begin{tabular}{|c|c|c|c|c|c|c|}
\hline \multirow[b]{3}{*}{$\mathbf{C P}$} & \multicolumn{6}{|c|}{ Correção da umidade - LOGSDON (1998) } \\
\hline & \multicolumn{3}{|c|}{ Padrão } & \multicolumn{3}{|c|}{ CCA } \\
\hline & $\begin{array}{l}\mathbf{E}_{\mathrm{c} 0, \mathrm{NBR}} \\
\text { (MPa) }\end{array}$ & $\begin{array}{l}\mathbf{E}_{\mathrm{c} 0 \text {,Regr }} \\
(\mathrm{MPa})\end{array}$ & $\begin{array}{c}\Delta \\
(\%)\end{array}$ & $\begin{array}{l}\mathbf{E}_{\mathrm{c} 0, \mathrm{NBR}} \\
\text { (MPa) }\end{array}$ & $\begin{array}{l}\mathbf{E}_{\text {c0,Regr }} \\
\text { (MPa) }\end{array}$ & $\begin{array}{c}\Delta \\
(\%)\end{array}$ \\
\hline ANG-01 & 24583 & 24514 & $-0,3$ & 27279 & 27005 & $-1,0$ \\
\hline ANG-02 & 24781 & 23836 & $-3,8$ & 24244 & 24157 & $-0,4$ \\
\hline ANG-03 & 23308 & 25852 & 10,9 & 24906 & 24779 & $-0,5$ \\
\hline ANG-04 & 18461 & 20016 & 8,4 & 19412 & 19426 & 0,1 \\
\hline ANG-05 & 25152 & 25073 & 0,3 & 24611 & 24752 & 0,6 \\
\hline ANG-06 & 20343 & 20334 & 0,0 & 23094 & 23092 & 0,0 \\
\hline
\end{tabular}

De acordo com estas tabelas, é grande a semelhança entre os valores do módulo de elasticidade longitudinal determinado pela expressão recomendada pela NBR 7190/97 ( $\left.\mathrm{E}_{\mathrm{c} 0, \mathrm{NBR}}\right)$ e através da regressão linear simples $\left(\mathrm{E}_{\mathrm{c} 0, \mathrm{Regr}}\right)$, tanto para os CP's sem preservação quanto para aqueles submetidos à preservação.

Portanto, de modo geral, para aceitar a semelhança estatística entre dois conjuntos de dados quaisquer, optou-se pela aplicação do Teste de Dados Pareados (Pairing). Assim sendo, o procedimento deste teste é dado da seguinte maneira:

$1^{\circ}$ ) Defina uma nova variável (desvio: $\mathrm{X}$ ) a partir da diferença entre valores correspondentes dos conjuntos considerados,

$$
X=V_{\text {conj } 01}-V_{\text {conj } 02}
$$

$2^{\circ}$ ) Utilizando a definição do Intervalo de Confiança da Média das Diferenças, verifique a equivalência dos dados,

$$
\left.\bar{X}-t(95 \%)) \frac{s_{d}}{\sqrt{n}} \leq \mu_{x} \leq \bar{X}+t(95 \%)\right) \frac{s_{d}}{\sqrt{n}}
$$

Onde, 
* $\bar{X}$ : média aritmética do conjunto de valores obtidos a partir da diferença entre os módulos de elasticidade longitudinal.

As demais grandezas apresentadas na expressão acima já foram definidas anteriormente (p. 69).

Como exemplo de aplicação deste teste será empregado o conjunto de dados dos CP's tratados com CCA e umidade corrigida segundo recomendações da NBR 7190/97. Então,

*n: número de corpos-de-prova da amostra $\Rightarrow \mathrm{n}=6$;

$* \phi$ : graus de liberdade $\Rightarrow \phi=5$;

*t(95\%): coeficiente da Distribuição “ $t$ ” $\Rightarrow \mathrm{t}(95 \%)=2,5706$;

${ }^{*} \mathrm{~s}_{\mathrm{d}}$ : desvio-padrão da amostra $\Rightarrow \mathrm{s}_{\mathrm{d}}=137,1 \mathrm{MPa}$;

$* \bar{X}$ : média do desvio $(\mathrm{X}) \Rightarrow \bar{X}=54,1 \mathrm{MPa}$.

Aplicando as expressões 03 e 04, obtém-se o seguinte intervalo de confiança,

$$
-89,8 \leq \mu_{x} \leq 198,0
$$

De acordo com o resultado, percebe-se que o intervalo de confiança da média contém o valor zero, podendo assim a média ser nula e os conjuntos de dados serem estatisticamente equivalentes. Para os demais conjuntos esta hipótese também foi aceita.

A verificação da variabilidade dos valores do módulo de elasticidade longitudinal foi realizada através dos parâmetros básicos da distribuição normal, a partir dos dados obtidos da regressão linear.

TABELA 17 - Parâmetros estatísticos para rigidez à compressão paralela às fibras Angelim

\begin{tabular}{|c|c|c|c|c|c|c|c|}
\hline \multicolumn{8}{|c|}{ Método de correção da umidade } \\
\hline \multicolumn{4}{|c|}{ NBR 7190/97 } & \multicolumn{4}{|c|}{ LOGSDON (1998) } \\
\hline \multicolumn{2}{|c|}{ Padrão } & \multicolumn{2}{|c|}{ CCA } & \multicolumn{2}{|c|}{ Padrão } & \multicolumn{2}{|c|}{ CCA } \\
\hline $\mathbf{E}_{\mathrm{c} 0, \mathrm{~m}}(\mathrm{MPa})$ & CV (\%) & $\mathbf{E}_{\mathrm{c} 0, \mathrm{~m}}(\mathrm{MPa})$ & CV (\%) & $\mathbf{E}_{\mathrm{c} 0, \mathrm{~m}}(\mathrm{MPa})$ & CV (\%) & $\mathbf{E}_{\mathrm{c} 0, \mathrm{~m}}(\mathbf{M P a})$ & CV (\%) \\
\hline 22763 & 10,3 & 23073 & 10,6 & 23271 & 10,7 & 23868 & 10,6 \\
\hline
\end{tabular}

Da tabela acima, referente a rigidez à compressão paralela às fibras, notou-se que, para quaisquer formas de correção da umidade, não houve diferença entre os valores dos coeficientes de variação dos CP's naturais e preservados. 
Diante dos resultados obtidos (Tabelas 12, 15 e 16), elaborou-se a Tabela 18, cujos valores representam o quociente das propriedades de resistência e rigidez entre os CP's impregnados e sem preservação.

TABELA 18 - Relação da resistência e da rigidez entre os CP's preservado (CCA) e os naturais (sem preservação) - Angelim

\begin{tabular}{|c|c|c|c|c|c|c|}
\hline \multirow{2}{*}{$\mathbf{C P}$} & \multicolumn{3}{|c|}{ NBR 7190/97 } & \multicolumn{3}{|c|}{ LOGSDON (1998) } \\
\hline & $\left(\mathbf{f}_{\mathrm{c} 0, \mathrm{CCA}} / \mathbf{f}_{\mathrm{c} 0, \mathrm{p}}\right)$ & $\left(\mathbf{f}_{\mathrm{v} 0, \mathrm{CCA}} / \mathbf{f}_{\mathrm{v} 0, \mathrm{p}}\right)$ & $\left(\mathbf{E}_{\mathrm{c} 0, \mathrm{CCA}} / \mathbf{E}_{\mathrm{c} 0, \mathrm{p}}\right)_{\mathrm{Regr}}$ & $\left(\mathbf{f}_{\mathrm{c} 0, \mathrm{CCA}} / \mathbf{f}_{\mathrm{c} 0, \mathrm{p}}\right)$ & $\left(\mathbf{f}_{\mathrm{v} 0, \mathrm{CCA}} / \mathbf{f}_{\mathrm{v} 0, \mathrm{p}}\right)$ & $\left(\mathbf{E}_{\mathrm{c} 0, \mathrm{CCA}} / \mathbf{E}_{\mathrm{c} 0, \mathrm{p}}\right)_{\mathrm{Regr}}$ \\
\hline ANG-01 & 0,92 & 1,05 & 1,09 & 0,92 & 1,05 & 1,10 \\
\hline ANG-02 & 0,88 & 0,87 & 1,00 & 0,89 & 0,86 & 1,01 \\
\hline ANG-03 & 0,90 & 1,03 & 0,95 & 0,91 & 1,03 & 0,96 \\
\hline ANG-04 & 1,06 & 1,11 & 0,95 & 1,09 & 1,11 & 0,97 \\
\hline ANG-05 & 0,95 & 1,09 & 0,98 & 0,96 & 1,08 & 0,99 \\
\hline ANG-06 & 0,94 & 1,08 & 1,13 & 0,94 & 1,07 & 1,14 \\
\hline
\end{tabular}

como artifício a média aritmética e o coeficiente de variação (ver Tabela 19).

TABELA 19 - Parâmetros estatísticos da relação da resistência e da rigidez entre os CP's preservado (CCA) e os naturais (sem preservação) - Angelim

\begin{tabular}{|c|c|c|c|c|c|c|c|c|c|c|c|}
\hline \multicolumn{6}{|c|}{ NBR 7190/97 } & \multicolumn{6}{|c|}{ LOGSDON (1998) } \\
\hline \multicolumn{2}{|c|}{$\left(\mathbf{f}_{\mathrm{c} 0, \mathrm{CCA}} / \mathbf{f}_{\mathrm{c} 0, \mathrm{p}}\right)$} & \multicolumn{2}{|c|}{$\left(\mathbf{f}_{\mathrm{v} 0, \mathrm{CCA}} / \mathbf{f}_{\mathrm{v} 0, \mathrm{p}}\right)$} & \multicolumn{2}{|c|}{$\left(\mathbf{E}_{\mathrm{c} 0, \mathrm{CCA}} / \mathbf{E}_{\mathrm{c} 0, \mathrm{p}}\right)_{\mathrm{Regr}}$} & \multicolumn{2}{|c|}{$\left(\mathbf{f}_{\mathrm{c} 0, \mathrm{CCA}} / \mathbf{f}_{\mathbf{c} 0, \mathrm{p}}\right)$} & \multicolumn{2}{|c|}{$\left(\mathbf{f}_{\mathrm{v} 0, \mathrm{CCA}} / \mathbf{f}_{\mathrm{v} 0, \mathrm{p}}\right)$} & \multicolumn{2}{|c|}{$\left(\mathbf{E}_{\mathrm{c} 0, \mathrm{CCA}} / \mathbf{E}_{\mathrm{c} 0, \mathrm{p}}\right)_{\mathrm{Regr}}$} \\
\hline Média & $\begin{array}{l}\text { CV } \\
(\%)\end{array}$ & Média & $\begin{array}{l}\text { CV } \\
(\%)\end{array}$ & Média & $\begin{array}{l}\text { CV } \\
(\%)\end{array}$ & Média & $\begin{array}{l}\text { CV } \\
(\%)\end{array}$ & Média & $\begin{array}{l}\text { CV } \\
(\%)\end{array}$ & Média & CV \\
\hline$\overline{0,94}$ & 6,7 & 1,04 & 8,4 & 1,0 & 7,4 & $\overline{0,4}$ & 7,6 & 1,0 & 8 , & & 7,2 \\
\hline
\end{tabular}

Da Tabela 19 pode-se observar, para ambas as formas de correção de umidade, que as médias das resistências e da rigidez se mantiveram praticamente inalteradas.

Considerando apenas a correção da umidade apresentada na NBR 7190/97 para os resultados dos ensaios à compressão paralela às fibras, seria verificada uma redução de seis por cento da resistência dos CP's preservados em relação aos naturais (sem preservação) e um coeficiente de variação inferior a sete por cento, confirmando a baixa dispersão. Apesar disto, os dados da Tabela 12 confirmaram que, do ponto de vista estatístico, os conjuntos de dados referentes aos CP's tratados e naturais podem ser considerados equivalentes, ou seja, o intervalo de confiança da média das diferenças contém o zero $\left(-0,8 \leq \mu_{x} \leq 8,0\right)$. Tal fato é demonstrado através do emprego das expressões (03) e (04).

Sobre o módulo de elasticidade longitudinal, pode-se perceber em princípio que, os CP's preservados sofreram em média um acréscimo de dois pontos percentuais e um coeficiente de variação inferior a oito por cento. Analisando os 
dados da Tabela 15 e utilizando o Teste de Dados Pareados, foi possível verificar a equivalência dos conjuntos. Para tanto, obteve-se o seguinte intervalo de confiança para a média das diferenças, $\left(-1406 \leq \mu_{x} \leq 2026\right)$.

Em virtude da equivalência dos dados para a resistência e rigidez, é conveniente considerar um fator igual a 1.0, ou seja, desconsiderar o efeito da preservação e do processo preservativo nas propriedades mecânicas das peças de madeira.

Considerando a correção da umidade proposta por LOGSDON (1998) e ensaios à compressão paralela às fibras, verificou-se uma redução média de cinco por cento da resistência dos CP's preservado em relação aos naturais (sem preservação) e um acréscimo de três por cento para o módulo de elasticidade longitudinal. Com base nos dados das Tabelas 15 e 16, verificou-se que ambos os conjuntos, resistência e rigidez, são estatisticamente equivalentes. Por isso, pode ser desconsiderado o efeito do produto/processo nas peças de madeira, adotando então, um fator igual a um.

Considerando os CP's submetidos aos ensaios de cisalhamento paralelo às fibras e a correção da umidade através das recomendações da NBR 7190/97, verificou-se um aumento de quatro por cento da resistência dos CP's preservado em relação aos naturais. Segundo LOGSDON (1998), este aumento atingiu três por cento. Usando a Tabela 12, verificou-se que os conjuntos de dados referentes aos CP's tratados e naturais são equivalentes. Este fato foi demonstrado através do emprego das expressões (03) e (04),

*Correção (NBR 7190/97) - -0,4 $\leq \mu_{x} \leq 1,6$;

*Correção (LOGSDON (1998)) - - 0,5 $\leq \mu_{x} \leq 1,4$.

Foi observado um coeficiente de variação por volta de oito por cento, confirmando assim, a baixa dispersão dos mesmos ao redor da média. Assim sendo, não é necessário considerar um fator de correção para quantificar a relação entre a resistência à compressão paralela, a resistência ao cisalhamento paralelo e o módulo de elasticidade longitudinal da madeira natural e madeira tratada com CCA sob pressão, referente à espécie Angelim.

Após todas as discussões, os valores médios assumem a confiabilidade necessária e, desta forma podem ser adotados como fatores que corrigem e 
quantifiquem o efeito do produto e do processo preservativo nas propriedades mecânicas da madeira. A Tabela 20 mostra os referidos valores.

TABELA 20 - Fator K - efeito do preservativo e do processo de tratamento nas propriedades mecânicas da madeira - Angelim

\begin{tabular}{|c|c|c|c|c|c|}
\hline \multicolumn{3}{|c|}{ NBR 7190/97 } & \multicolumn{3}{|c|}{ LOGSDON (1998) } \\
\hline$\left(\mathbf{f}_{\mathrm{c} 0, \mathrm{CCA}} / \mathbf{f}_{\mathrm{c} 0, \mathrm{p}}\right)$ & $\left(\mathbf{f}_{\mathrm{v} 0, \mathrm{CCA}} / \mathbf{f}_{\mathrm{v} 0, \mathrm{p}}\right)$ & $\left(\mathbf{E}_{\mathrm{c} 0, \mathrm{CCA}} / \mathrm{E}_{\mathrm{c} 0, \mathrm{p}}\right)_{\mathrm{Regr}}$ & $\left(\mathbf{f}_{\mathrm{c} 0, \mathrm{CCA}} / \mathbf{f}_{\mathrm{c} 0, \mathrm{p}}\right)$ & $\left(\mathbf{f}_{\mathrm{v} 0, \mathrm{CCA}} / \mathbf{f}_{\mathrm{v} 0, \mathrm{p}}\right)$ & $\left(\mathbf{E}_{\mathrm{c} 0, \mathrm{CCA}} / \mathbf{E}_{\mathrm{c} 0, \mathrm{p}}\right)_{\mathrm{Regr}}$ \\
\hline 1,0 & 1,0 & 1,0 & 1,0 & 1,0 & 1,0 \\
\hline
\end{tabular}

\subsubsection{Ipê (Tabebuia sp)}

A partir dos ensaios de compressão paralela às fibras, foram obtidos valores de resistência característica para os CP's naturais iguais a $81,5 \mathrm{MPa}$ e $80,5 \mathrm{MPa}$, com correção da umidade segundo NBR 7190/97 e LOGSDON (1998), respectivamente. Destes resultados, verificou-se uma redução próxima a 1,2\%. Para os CP's impregnados com preservativo CCA ocorreu o inverso, isto é, foram obtidos valores iguais a $80,6 \mathrm{MPa}$ e $81,2 \mathrm{MPa}$, provocando um acréscimo de aproximadamente $0,8 \%$ devido a correção sugerida por LOGSDON (1998). Desta forma, através de ambas as maneiras de correção de umidade, os resultados alcançados levam a mesma classe de resistência, ou seja, classe C-60. Tais resultados foram obtidos, para CP's naturais e preservados, com uma umidade média de aproximadamente 8,8 e $8,5 \%$, respectivamente.

Foi verificado, para ambas as formas de correção da umidade, uma ligeira variação entre os valores das resistências características dos CP's naturais e preservados. Através da correção recomendada pela NBR 7190/97, os CP's tratados tiveram uma redução de 1,1\%, enquanto a proposta de LOGSDON (1998), levou a um acréscimo de $0,8 \%$.

No cisalhamento paralelo, as resistências características dos CP's sem preservação atingiram os valores 8,5MPa (NBR 7190/97) e 8,4MPa (LOGSDON (1998)). Enquanto para os CP's preservados foram obtidos respectivamente, 10,3MPa e 9,9MPa. No primeiro caso, a recomendação da NBR 7190/97 levou a um aumento de $1,3 \%$, enquanto nos CP's preservados chegou a 3,5\%. Neste caso, os Cp's naturais foram ensaiados com teor de umidade em torno de $10,1 \%$, enquanto os impregnados atingiram $10,3 \%$. 
Observou-se que a proposta de LOGSDON (1998) aumentou a resistência característica ao cisalhamento dos CP's preservados de aproximadamente 18,4\%, enquanto a correção prescrita pela NBR 7190/97 atingiu 21,0\%.

A Tabela 21 apresenta de forma resumida os valores discutidos acima.

TABELA 21 - Resistência característica à compressão e ao cisalhamento paralelo Ipê

\begin{tabular}{|c|c|c|c|c|c|c|c|}
\hline \multicolumn{4}{|c|}{ Resistência à compressão paralela } & \multicolumn{4}{|c|}{ Resistência ao cisalhamento paralelo } \\
\hline \multicolumn{2}{|c|}{ NBR 7190/97 } & \multicolumn{2}{|c|}{ LOGSDON (1998) } & \multicolumn{2}{|c|}{ NBR 7190/97 } & \multicolumn{2}{|c|}{ LOGSDON (1998) } \\
\hline $\begin{array}{c}\mathbf{f}_{\mathrm{co}, \mathrm{k}, \mathrm{p}} \\
(\mathrm{MPa})\end{array}$ & $\begin{array}{l}\mathbf{f}_{\mathrm{c} 0, \mathrm{k}, \mathrm{CCA}} \\
(\mathrm{MPa})\end{array}$ & $\begin{array}{c}\mathbf{f}_{\mathrm{co}, \mathrm{k}, \mathrm{p}} \\
(\mathrm{MPa})\end{array}$ & $\begin{array}{c}\mathbf{f}_{\mathrm{c0}, \mathrm{k}, \mathrm{CCA}} \\
(\mathrm{MPa})\end{array}$ & $\begin{array}{l}\mathbf{f}_{\mathrm{v0}, \mathrm{k}, \mathrm{p}} \\
(\mathrm{MPa})\end{array}$ & $\begin{array}{c}\mathbf{f}_{\mathrm{v} 0, \mathrm{k}, \mathrm{CCA}} \\
(\mathrm{MPa})\end{array}$ & $\begin{array}{l}\mathbf{f}_{\mathrm{v} 0, \mathrm{k}, \mathrm{p}} \\
(\mathrm{MPa})\end{array}$ & $\begin{array}{l}\mathbf{f}_{\mathrm{v} 0, \mathrm{k}, \mathrm{CCA}} \\
(\mathrm{MPa})\end{array}$ \\
\hline 81,5 & 80,6 & 80,5 & 81,2 & 8,5 & 10,3 & 8,4 & 9,9 \\
\hline
\end{tabular}

Os valores característicos apresentados na tabela acima foram calculados a partir dos resultados de cada CP ensaiado (ver a seguir, Tabela 22), cujo valor médio da massa específica aparente $\left(\rho_{12}\right)$ é de $0,91 \mathrm{~g} / \mathrm{cm}^{3}$, sendo cada valor individual corrigido para a umidade de $12 \%$, utilizando-se para tal o diagrama de Kollmann.

TABELA 22 - Valores individuais de resistência à compressão e ao cisalhamento paralelo - Ipê

\begin{tabular}{c|c|c|c|c|c|c|c|c}
\hline \multirow{2}{*}{ CP } & \multicolumn{3}{|c|}{ Resistência à compressão paralela } & \multicolumn{3}{c}{ Resistência ao cisalhamento paralelo } \\
\cline { 2 - 9 } & $\begin{array}{c}\text { NBR 7190/97 } \\
\text { (MPa) }\end{array}$ & \multicolumn{2}{c|}{$\begin{array}{c}\text { LOGSDON (1998) } \\
\text { (MPa) }\end{array}$} & \multicolumn{2}{c}{$\begin{array}{c}\text { NBR 7190/97 } \\
\text { (MPa) }\end{array}$} & \multicolumn{2}{c}{$\begin{array}{c}\text { LOGSON (1998) } \\
\text { (MPa) }\end{array}$} \\
\cline { 2 - 8 } & Padrão & CCA & Padrão & CCA & Padrão & CCA & Padrão & CCA \\
\hline IPÊ-01 & 74,7 & 78,6 & 74,2 & 80,9 & 12,8 & 12,8 & 12,9 & 12,5 \\
IPÊ-02 & 106,3 & 105,5 & 105,2 & 104,4 & 18,2 & 16,4 & 18,4 & 16,6 \\
IPÊ-03 & 81,3 & 83,1 & 80,8 & 85,7 & 12,2 & 12,1 & 12,2 & 11,9 \\
IPÊ-04 & 80,6 & 77,9 & 79,7 & 78,7 & 17,3 & 15,7 & 17,5 & 15,5 \\
IPÊ-05 & 97,5 & 99,4 & 96,2 & 102,2 & 22,8 & 19,6 & 22,8 & 19,4 \\
IPÊ-06 & 93,3 & 93,5 & 92,3 & 95,7 & 21,7 & 20,2 & 21,3 & 20,4 \\
\hline
\end{tabular}

Em função da discussão registrada no Item 4.2.1.1, os CPs à compressão e ao cisalhamento paralelo às fibras serão expressos a partir do coeficiente de variação.

Da realização dos ensaios de compressão paralela às fibras, foram determinados os valores das resistências e seus respectivos parâmetros estatísticos.

TABELA 23 - Parâmetros estatísticos para resistência à compressão paralela - Ipê

\begin{tabular}{|c|c|c|c|c|c|c|c|}
\hline \multicolumn{8}{|c|}{ Método de correção da umidade } \\
\hline \multicolumn{4}{|c|}{ NBR 7190/97 } & \multicolumn{4}{|c|}{ LOGSDON (1998) } \\
\hline \multicolumn{2}{|c|}{ Padrão } & \multicolumn{2}{|c|}{ CCA } & \multicolumn{2}{|c|}{ Padrão } & \multicolumn{2}{|c|}{$\mathrm{CCA}$} \\
\hline $\mathrm{f}_{\mathrm{c} 0, \mathrm{~m}}(\mathrm{MPa})$ & CV (\%) & $\mathrm{f}_{\mathrm{c} 0, \mathrm{~m}}(\mathrm{MPa})$ & CV (\%) & $\mathrm{f}_{\mathrm{c} 0, \mathrm{~m}}(\mathrm{MPa})$ & CV (\%) & $\mathrm{f}_{\mathrm{c} 0, \mathrm{~m}}(\mathrm{MPa})$ & CV (\%) \\
\hline 89,0 & 13,5 & 89,6 & 12,9 & 88,1 & 13,4 & 91,3 & 12,1 \\
\hline
\end{tabular}

Para os CP's submetidos ao cisalhamento paralelo às fibras, foram determinadas as resistências e calculados os parâmetros estatísticos básicos.

TABELA 24 - Parâmetros estatísticos para resistência ao cisalhamento paralelo - Ipê 


\begin{tabular}{c|c|c|c|c|c|c|c}
\hline \multicolumn{7}{c}{ Método de correção da umidade } \\
\hline \multicolumn{3}{c|}{ NBR 7190/97 } & \multicolumn{3}{c}{ LOGSDON (1998) } \\
\hline \multicolumn{2}{c|}{ Padrão } & \multicolumn{2}{c|}{ CCA } & \multicolumn{2}{c}{ Padrão } & \multicolumn{3}{c}{ CCA } \\
\hline $\mathbf{f}_{\mathrm{v} 0, \mathrm{~m}}(\mathbf{M P a})$ & $\mathbf{C V ~ ( \% )}$ & $\mathbf{f}_{\mathrm{v} 0, \mathrm{~m}}(\mathrm{MPa})$ & $\mathbf{C V}(\%)$ & $\mathbf{f}_{\mathrm{v} 0, \mathrm{~m}}(\mathrm{MPa})$ & $\mathbf{C V}(\%)$ & $\mathbf{f}_{\mathrm{v} 0, \mathrm{~m}}(\mathbf{M P a})$ & $\mathbf{C V}(\%)$ \\
\hline 17,5 & 25,1 & 16,1 & 20,6 & 17,5 & 24,7 & 16,1 & 21,6 \\
\hline
\end{tabular}

Conforme os resultados da resistência à compressão paralela às fibras (Tabela 23), foi observado que para quaisquer formas de correção da umidade, a diferença dos valores dos coeficientes de variação entre os CP's naturais e preservados foi em torno de um porcento. Da Tabela 24, os dados sobre o cisalhamento paralelo às fibras e, pode ser notado que tal diferença não atingiu cinco pontos percentuais.

Portanto, assim como para a espécie anterior, admite-se que os resultados, devido a anisotropia do material, não foram influenciados de maneira relevante.

Nesta espécie o módulo de elasticidade longitudinal de cada CP também foi obtido de duas maneiras distintas, isto é, segundo as recomendações da NBR 7190/97 - Anexo B (Item 8) e através de uma regressão linear simples. Os resultados estão apresentados nas Tabelas 25 e 26 e como ilustração, a Figura 18 traz um exemplo do módulo de elasticidade obtido através da regressão linear.

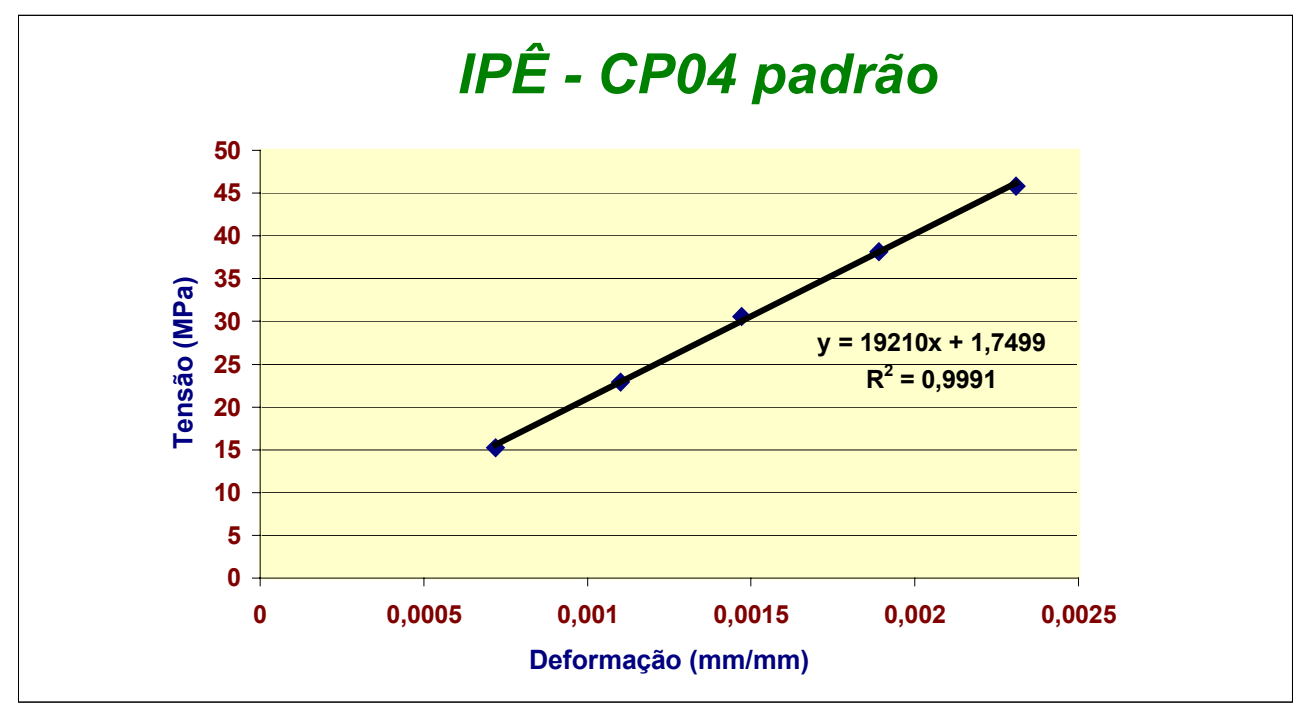

FIGURA 18 - Módulo de elasticidade longitudinal do Ipê - (regressão linear simples) 
TABELA 25 - Valores de rigidez à compressão paralela - NBR 7190/97 - Ipê

\begin{tabular}{|c|c|c|c|c|c|c|}
\hline \multirow[b]{3}{*}{$\mathbf{C P}$} & \multicolumn{6}{|c|}{ Correção da umidade - NBR 7190/97 } \\
\hline & \multicolumn{3}{|c|}{ Padrão } & \multicolumn{3}{|c|}{ CCA } \\
\hline & $\begin{array}{l}\mathbf{E}_{\mathrm{c} 0, \mathrm{NBR}} \\
(\mathrm{MPa})\end{array}$ & $\begin{array}{l}\mathbf{E}_{\mathrm{c} 0 \text {,Regr }} \\
(\mathrm{MPa})\end{array}$ & $\begin{array}{c}\Delta \\
(\%) \\
\end{array}$ & $\begin{array}{l}\mathbf{E}_{\mathrm{c} 0, \mathrm{NBR}} \\
(\mathrm{MPa}) \\
\end{array}$ & $\begin{array}{l}\mathbf{E}_{\text {c0,Regr }} \\
(\mathrm{MPa})\end{array}$ & $\begin{array}{c}\Delta \\
(\%)\end{array}$ \\
\hline IPÊ-01 & 23288 & 22734 & $-2,4$ & 22686 & 22712 & 0,1 \\
\hline IPÊ-02 & 23862 & 23496 & $-1,5$ & 26566 & 26316 & $-0,9$ \\
\hline IPÊ-03 & 21935 & 21932 & 0,0 & 23397 & 23334 & $-0,3$ \\
\hline IPÊ-04 & 18431 & 18442 & 0,1 & 17692 & 16993 & $-4,0$ \\
\hline IPÊ-05 & 21675 & 21674 & 0,0 & 23329 & 23226 & $-0,4$ \\
\hline IPÊ-06 & 26616 & 25852 & $-2,9$ & 27110 & 26674 & $-1,6$ \\
\hline
\end{tabular}

TABELA 26 - Valores de rigidez à compressão paralela - LOGSDON (1998) - Ipê

\begin{tabular}{|c|c|c|c|c|c|c|}
\hline \multirow[b]{3}{*}{$\mathrm{CP}$} & \multicolumn{6}{|c|}{ Correção da umidade - LOGSDON (1998) } \\
\hline & \multicolumn{3}{|c|}{ Padrão } & \multicolumn{3}{|c|}{ CCA } \\
\hline & $\begin{array}{l}\mathbf{E}_{\mathrm{c} 0, \mathrm{NBR}} \\
(\mathrm{MPa})\end{array}$ & $\begin{array}{l}\mathbf{E}_{\mathrm{c} 0, \mathrm{Regr}} \\
(\mathrm{MPa})\end{array}$ & $\begin{array}{c}\Delta \\
(\%)\end{array}$ & $\begin{array}{l}\mathbf{E}_{\mathrm{c0}, \mathrm{NBR}} \\
\text { (MPa) }\end{array}$ & $\begin{array}{l}\mathbf{E}_{\mathrm{c} 0, \mathrm{Regr}} \\
\text { (MPa) }\end{array}$ & $\begin{array}{c}\Delta \\
(\%)\end{array}$ \\
\hline IPÊ-01 & 23817 & 23250 & $-2,4$ & 23468 & 23495 & 0,1 \\
\hline IPÊ-02 & 23614 & 23251 & $-1,5$ & 26289 & 26041 & $-0,9$ \\
\hline IPÊ-03 & 21800 & 21797 & 0,0 & 24204 & 24138 & $-0,3$ \\
\hline IPÊ-04 & 18239 & 18250 & 0,1 & 17862 & 17156 & $-4,0$ \\
\hline IPÊ-05 & 21450 & 21448 & 0,0 & 23086 & 22984 & $-0,4$ \\
\hline IPÊ-06 & 27275 & 26492 & $-2,9$ & 26828 & 26396 & $-1,6$ \\
\hline
\end{tabular}

Devido a grande semelhança entre os valores do módulo de elasticidade longitudinal determinado pela expressão recomendada pela NBR $7190 / 97\left(\mathrm{E}_{\mathrm{c} 0, \mathrm{NBR}}\right) \mathrm{e}$ através da regressão linear simples $\left(\mathrm{E}_{\mathrm{c} 0 \text {,Regr }}\right)$, tanto para os CP's sem preservação quanto para aqueles submetidos à preservação, empregou-se o Teste de Dados Pareados (Pairing) para mostrar tal equivalência estatística. Como exemplo de aplicação do teste em questão será empregado o conjunto de dados dos CP's sem preservação e umidade corrigida segundo as sugestões de LOGSDON (1998). Procedendo da mesma forma como mostrado no Item 4.2.1.1, chegou-se nos seguintes limites: $-73,4 \leq \mu_{x} \leq 641,9$. Conforme o resultado, verificou-se que o intervalo de confiança da média contém o valor zero e, consequentemente, o diagrama dos desvios não apresenta tendenciosidade. Desta forma, conclui-se que os conjuntos de dados são estatisticamente equivalentes. Para os demais conjuntos esta hipótese também foi aceita.

A verificação da variabilidade dos valores do módulo de elasticidade longitudinal foi realizada através dos parâmetros básicos da distribuição normal, a partir dos dados obtidos da regressão linear (Tabela 27). 
TABELA 27- Parâmetros estatísticos para rigidez à compressão paralela - Ipê

\begin{tabular}{|c|c|c|c|c|c|c|c|}
\hline \multicolumn{8}{|c|}{ Método de correção da umidade } \\
\hline \multicolumn{4}{|c|}{ NBR 7190/97 } & \multicolumn{4}{|c|}{ LOGSDON (1998) } \\
\hline \multicolumn{2}{|c|}{ Padrão } & \multicolumn{2}{|c|}{ CCA } & \multicolumn{2}{|c|}{ Padrão } & \multicolumn{2}{|c|}{ CCA } \\
\hline $\mathbf{E}_{\mathrm{c} 0, \mathrm{~m}}(\mathrm{MPa})$ & CV (\%) & $\mathbf{E}_{\mathrm{c} 0, \mathrm{~m}}(\mathrm{MPa})$ & CV (\%) & $\mathrm{E}_{\mathrm{c} 0, \mathrm{~m}}(\mathrm{MPa})$ & CV (\%) & $\mathbf{E}_{\mathrm{c} 0 \mathrm{~m}}(\mathrm{MPa})$ & CV (\%) \\
\hline 22355 & 10,9 & 23209 & 15,0 & 22415 & 12,1 & 23368 & 14,3 \\
\hline
\end{tabular}

Da tabela acima, para quaisquer formas de correção da umidade, houve uma diferença de aproximadamente um porcento entre os valores dos coeficientes de variação dos CP's naturais e preservados.

A partir dos resultados apresentados nas Tabelas 22, 25 e 26, obteve-se a Tabela 28, cujos valores representam o quociente das propriedades de resistência e rigidez entre os CP's preservados e naturais.

TABELA 28 - Relação da resistência e da rigidez entre os CP's preservado (CCA) e os naturais (sem preservação) - Ipê

\begin{tabular}{|c|c|c|c|c|c|c|}
\hline \multirow{2}{*}{$\mathbf{C P}$} & \multicolumn{3}{|c|}{ NBR 7190/97 } & \multicolumn{3}{|c|}{ LOGSDON (1998) } \\
\hline & $\left(\mathbf{f}_{\mathrm{c} 0, \mathrm{CCA}} / \mathbf{f}_{\mathrm{c} 0, \mathrm{p}}\right)$ & $\left(\mathbf{f}_{\mathrm{v} 0, \mathrm{CCA}} / \mathbf{f}_{\mathrm{v} 0, \mathrm{p}}\right)$ & $\left(\mathbf{E}_{\mathrm{c} 0, \mathrm{CCA}} / \mathbf{E}_{\mathrm{c} 0, \mathrm{p}}\right)_{\mathrm{Regr}}$ & $\left(\mathbf{f}_{\mathrm{c} 0, \mathrm{CCA}} / \mathbf{f}_{\mathrm{c} 0, \mathrm{p}}\right)$ & $\left(\mathbf{f}_{\mathrm{v} 0, \mathrm{CCA}} / \mathbf{f}_{\mathrm{v} 0, \mathrm{p}}\right)$ & $\left(\mathbf{E}_{\mathrm{c} 0, \mathrm{CCA}} / \mathbf{E}_{\mathrm{c} 0, \mathrm{p}}\right)_{\mathrm{Regr}}$ \\
\hline IPÊ-01 & 1,05 & 1,00 & 1,00 & 1,09 & 0,97 & 1,01 \\
\hline IPÊ-02 & 0,99 & 0,90 & 1,12 & 0,99 & 0,90 & 1,12 \\
\hline IPÊ-03 & 1,02 & 1,00 & 1,06 & 1,06 & 0,98 & 1,11 \\
\hline IPÊ-04 & 0,97 & 0,91 & 0,92 & 0,99 & 0,89 & 0,94 \\
\hline IPÊ-05 & 1,02 & 0,86 & 1,07 & 1,06 & 0,85 & 1,07 \\
\hline IPÊ-06 & 1,00 & 0,93 & 1,03 & 1,04 & 0,93 & 1,00 \\
\hline
\end{tabular}

Para mostrar a validade dos valores apresentados na tabela acima, usou-se como artifício a média aritmética e o coeficiente de variação, valores explicitados na Tabela 29.

TABELA 29 - Parâmetros estatísticos da relação da resistência e da rigidez entre os CP's preservado (CCA) e os naturais (sem preservação) - Ipê

\begin{tabular}{|c|c|c|c|c|c|c|c|c|c|c|c|}
\hline \multicolumn{6}{|c|}{ NBR 7190/97 } & \multicolumn{6}{|c|}{ LOGSDON (1998) } \\
\hline \multicolumn{2}{|c|}{$\left(\mathbf{f}_{\mathrm{c} 0, \mathrm{CCA}} / \mathbf{f}_{\mathbf{c} 0, \mathrm{p}}\right)$} & \multicolumn{2}{|c|}{$\left(\mathbf{f}_{\mathrm{v} 0, \mathrm{CCA}} / \mathbf{f}_{\mathrm{v} 0, \mathrm{p}}\right)$} & \multicolumn{2}{|c|}{$\left(\mathbf{E}_{\mathrm{c} 0, \mathrm{CCA}} / \mathbf{E}_{\mathrm{c} 0, \mathrm{p}}\right)_{\mathrm{Regr}}$} & \multicolumn{2}{|c|}{$\left(\mathbf{f}_{\mathrm{c} 0, \mathrm{CCA}} / \mathbf{f}_{\mathrm{c} 0, \mathrm{p}}\right)$} & \multicolumn{2}{|c|}{$\left(\mathbf{f}_{\mathrm{v} 0, \mathrm{CCA}} / \mathbf{f}_{\mathrm{v} 0, \mathrm{p}}\right)$} & \multicolumn{2}{|c|}{$\left(\mathbf{E}_{\mathrm{c} 0, \mathrm{CCA}} / \mathbf{E}_{\mathrm{c} 0, \mathrm{p}}\right)_{\mathrm{Regr}}$} \\
\hline Média & $\begin{array}{l}\text { CV } \\
(\%)\end{array}$ & Média & $\begin{array}{l}\text { CV } \\
(\%)\end{array}$ & Média & $\begin{array}{l}\text { CV } \\
(\%)\end{array}$ & Média & $\begin{array}{l}\text { CV } \\
(\%)\end{array}$ & Média & $\begin{array}{l}\text { CV } \\
(\%)\end{array}$ & Média & $\begin{array}{l}\text { CV } \\
(\%)\end{array}$ \\
\hline 1,01 & 2,8 & 0 , &, 0 & 1,03 & 6,7 & 1,04 & 4,0 & & 5,6 & & 6,8 \\
\hline
\end{tabular}

Dos dados acima, para ambas as formas de correção de umidade, percebeu-se que as médias das relações das resistências e da rigidez pouco se alteraram.

No que diz respeito à compressão paralela às fibras e de acordo com a correção da umidade proposta por LOGSDON (1998), verificou-se um acréscimo da resistência e da rigidez dos CP's preservados em relação aos naturais de quatro por cento e coeficientes de variação em torno de quatro e sete por cento, 
respectivamente. Na correção recomendada pela NBR 7190/97, a resistência aumentou apenas um por cento, enquanto o módulo de elasticidade longitudinal chegou a três pontos percentuais. Referente ao coeficiente de variação, os valores são equivalentes aos anteriores.

Para o cisalhamento paralelo, notou-se uma redução da resistência de sete ou oito por cento, dependendo da maneira de correção da umidade. O coeficiente de variação em ambos os casos ficou em torno de seis pontos percentuais.

Apesar de todos os casos terem mostrado baixa dispersão ao redor da média, a confiabilidade será verificada através da aplicação do Teste de Dados Pareados.

Da Tabela 22 verificou-se que os conjuntos de dados referentes aos CP's tratados e naturais submetidos à compressão paralela, com correção da umidade recomendada pela NBR 7190/97, podem ser considerados equivalentes, isto é, $\left(-1,7 \leq \mu_{x} \leq 6,8\right)$. O mesmo acontece quando tal correção é realizada pela sugestão de LOGSDON (1998). Para esta situação obteve-se o seguinte intervalo de confiança para a média das diferenças, $\left(-0,3 \leq \mu_{x} \leq 6,8\right)$.

Nas duas situações é conveniente adotar fator igual a 1,0, isto é, deve-se desconsiderar qualquer influência do produto preservativo e do processo de tratamento nas propriedades de resistência à compressão paralela às fibras para peças de Ipê .

Conforme os dados da Tabela 4.25 (referente à rigidez), obteve-se o intervalo de confiança a seguir $\left(-682,5 \leq \mu_{x} \leq 2390,6\right)$ e, consequentemente, verificou-se a equivalência dos dados dos conjuntos. O mesmo ocorreu a partir dos dados da Tabela 26, isto é, $\left(-633,0 \leq \mu_{x} \leq 2540,2\right)$. Em virtude dos resultados é conveniente considerar um fator igual a 1.0.

Em ambas as maneiras de correção da umidade aqui mencionadas, os conjuntos de dados referentes aos CP's tratados e naturais submetidos aos ensaios de cisalhamento paralelo (ver Tabela 22) não podem ser considerados equivalentes. Tal fato foi verificado através das expressões (03) e (04),

*Correção (NBR 7190/97): $0,1 \leq \mu_{x} \leq 2,6$;

*Correção (LOGSDON (1998)): $0,2 \leq \mu_{x} \leq 2,7$. 
Assim sendo, sugere-se um fator de redução da resistência igual a 0,93 e 0,92 para as correções da umidade segundo a NBR 7190/97 e LOGSDON (1998), respectivamente.

De forma resumida, a Tabela 30 mostra os valores propostos a serem adotados como fatores que considerem o efeito do produto e do processo preservativo nas propriedades mecânicas da madeira.

TABELA 30 - Fator K - efeito do preservativo e do processo de tratamento nas propriedades mecânicas da madeira - Ipê

\begin{tabular}{|c|c|c|c|c|c|}
\hline \multicolumn{3}{|c|}{ NBR 7190/97 } & \multicolumn{3}{|c|}{ LOGSDON (1998) } \\
\hline$\left(\mathbf{f}_{\mathrm{c} 0, \mathrm{CCA}} / \mathbf{f}_{\mathrm{c} 0, \mathrm{p}}\right)$ & $\left(\mathbf{f}_{\mathrm{v} 0, \mathrm{CCA}} / \mathbf{f}_{\mathrm{v} 0, \mathrm{p}}\right)$ & $\left(\mathbf{E}_{\mathrm{c} 0, \mathrm{CCA}} / \mathbf{E}_{\mathrm{c} 0, \mathrm{p}}\right)_{\mathrm{Regr}}$ & $\left(\mathbf{f}_{\mathrm{c} 0, \mathrm{CCA}} / \mathbf{f}_{\mathrm{c} 0, \mathrm{p}}\right)$ & $\left(\mathbf{f}_{\mathrm{v} 0, \mathrm{CCA}} / \mathbf{f}_{\mathrm{v} 0, \mathrm{p}}\right)$ & $\left(\mathbf{E}_{\mathrm{c} 0, \mathrm{CCA}} / \mathbf{E}_{\mathrm{c} 0, \mathrm{p}}\right)_{\mathrm{Regr}}$ \\
\hline
\end{tabular}

\subsubsection{Copaíba (Copaifera sp)}

Dos ensaios de cisalhamento paralelo às fibras foram obtidos para os CP's não preservados, valores de resistências características iguais a $18,7 \mathrm{MPa}(\mathrm{NBR}$ 7190/97) e 18,8MPa (LOGSDON (1998)), com base em uma umidade média de $11,9 \%$. Entretanto, para os CP's preservados obteve-se respectivamente, $18,8 \mathrm{MPa}$ e 19,0MPa, para teor de umidade médio igual a 7,4\%. A resistência característica estimada para a amostra sem tratamento, obtida através das recomendações da NBR 7190/97, foi aproximadamente $0,5 \%$ inferior, enquanto nos CP's preservados a diferença chegou a $1,1 \%$.

Comparando as resistências características obtidas através de ambas as formas de correção de umidade aqui mencionadas, foi observado um aumento inferior a $1 \%$ por parte dos CP's preservados.

Conforme os resultados dos ensaios de compressão paralela às fibras, a resistência característica dos CP's sem tratamento preservativo são iguais a 73,6 $\mathrm{MPa}$ e 74,2MPa, com base na correção da umidade segundo NBR 7190/97 e LOGSDON (1998), respectivamente. Destes resultados, verificou-se uma redução em torno de 0,8\%. Para os CP's impregnados ocorreu o inverso, isto é, foram obtidos valores iguais a 79,0 MPa e 78,7 MPa, provocando um acréscimo de aproximadamente 0,5\% devido a correção sugerida pela NBR 7190/97. Para tanto, foi verificado que umidade de ensaio era de 12,5 e $8,5 \%$ para os CP's naturais e preservados, respectivamente. 
Desta forma, para ambas as situações, os resultados alcançados classificam a amostra como classe C-60.

Foi verificado, para ambas as formas de correções da umidade, uma variação entre os valores das resistências características dos CP's preservados e sem preservação. Através da correção recomendada pela NBR 7190/97, os CP's tratados tiveram um aumento de 7,4\%, enquanto a proposta de LOGSDON (1998), levou a um acréscimo de 6,0\%.

A Tabela 31 apresenta de forma resumida os valores discutidos acima.

TABELA 31 - Resistência característica à compressão e ao cisalhamento paralelo Copaíba

\begin{tabular}{|c|c|c|c|c|c|c|c|}
\hline \multicolumn{4}{|c|}{ Resistência à compressão paralela } & \multicolumn{4}{|c|}{ Resistência ao cisalhamento paralelo } \\
\hline \multicolumn{2}{|c|}{ NBR 7190/97 } & \multicolumn{2}{|c|}{ LOGSDON (1998) } & \multicolumn{2}{|c|}{ NBR 7190/97 } & \multicolumn{2}{|c|}{ LOGSDON (1998) } \\
\hline $\begin{array}{l}\mathbf{f}_{\mathrm{c} 0, \mathrm{k}, \mathrm{p}} \\
(\mathrm{MPa})\end{array}$ & $\begin{array}{c}\mathbf{f}_{\mathrm{c} 0, \mathrm{k}, \mathrm{CCA}} \\
(\mathrm{MPa})\end{array}$ & $\begin{array}{c}\mathbf{f}_{\mathrm{c0}, \mathrm{k}, \mathrm{p}} \\
(\mathrm{MPa})\end{array}$ & $\begin{array}{c}\mathbf{f}_{\mathrm{c} 0, \mathrm{k}, \mathrm{CCA}} \\
(\mathrm{MPa})\end{array}$ & $\begin{array}{l}\mathbf{f}_{\mathrm{v} 0, \mathrm{k}, \mathrm{p}} \\
(\mathrm{MPa})\end{array}$ & $\begin{array}{c}\mathbf{f}_{\mathrm{v} 0, \mathrm{k}, \mathrm{CCA}} \\
(\mathrm{MPa})\end{array}$ & $\begin{array}{l}\mathbf{f}_{\mathrm{v} 0, \mathrm{k}, \mathrm{p}} \\
(\mathrm{MPa})\end{array}$ & $\begin{array}{c}\mathbf{f}_{\mathrm{v} 0, \mathrm{k}, \mathrm{CCA}} \\
(\mathrm{MPa})\end{array}$ \\
\hline 73,6 & 79,0 & 74,2 & 78,7 & 18,7 & 18,8 & 18,8 & 19,0 \\
\hline
\end{tabular}

Os valores característicos apresentados na tabela acima foram calculados a partir dos resultados individuais mostrados na Tabela 32, cujo valor médio da massa específica aparente $\left(\rho_{12} \%\right)$ é de $0,87 \mathrm{~g} / \mathrm{cm}^{3}$. Esta média foi obtida a partir de cada valor individual corrigido para a umidade de 12\%, através do diagrama de

\section{Kollmann.}

TABELA 32 - Valores individuais de resistência à compressão e ao cisalhamento paralelo - Copaíba

\begin{tabular}{|c|c|c|c|c|c|c|c|c|}
\hline \multirow{3}{*}{$\mathbf{C P}$} & \multicolumn{4}{|c|}{ Resistência à compressão paralela } & \multicolumn{4}{|c|}{ Resistência ao cisalhamento paralelo } \\
\hline & \multicolumn{2}{|c|}{$\begin{array}{c}\text { NBR 7190/97 } \\
\text { (MPa) }\end{array}$} & \multicolumn{2}{|c|}{$\begin{array}{c}\text { LOGSDON (1998) } \\
(\mathrm{MPa})\end{array}$} & \multicolumn{2}{|c|}{$\begin{array}{c}\text { NBR 7190/97 } \\
\text { (MPa) }\end{array}$} & \multicolumn{2}{|c|}{$\begin{array}{c}\text { LOGSDON (1998) } \\
\text { (MPa) }\end{array}$} \\
\hline & Padrão & CCA & Padrão & CCA & Padrão & CCA & Padrão & CCA \\
\hline COP-01 & 73,3 & 76,7 & 72,5 & 75,9 & 18,7 & 18,5 & 18,7 & 18,7 \\
\hline COP-02 & 71,9 & 72,8 & 72,9 & 72,5 & 17,6 & 19,7 & 17,4 & 19,9 \\
\hline COP-03 & 79,1 & 79,8 & 79,5 & 79,0 & 18,6 & 20,0 & 18,5 & 20,2 \\
\hline COP-04 & 68,3 & 75,1 & 67,9 & 74,3 & 20,7 & 19,3 & 20,7 & 19,5 \\
\hline COP-05 & 75,2 & 77,3 & 74,4 & 76,5 & 19,9 & 22,1 & 20,1 & 20,3 \\
\hline COP-06 & 73,5 & 74,2 & 74,8 & 73,4 & 17,9 & 17,9 & 18,1 & 18,1 \\
\hline
\end{tabular}

Assim como nas discussões anteriores, os valores das resistências à compressão e ao cisalhamento paralelo às fibras de cada CP serão expressos a partir da média aritmética e do coeficiente de variação (ver Tabelas 33 e 34, respectivamente).

TABELA 33 - Parâmetros estatísticos para resistência à compressão paralela Copaíba 


\begin{tabular}{c|c|c|c|c|c|c|c}
\hline \multicolumn{7}{c}{ Método de correção da umidade } \\
\hline \multicolumn{3}{c|}{ NBR 7190/97 } & \multicolumn{3}{c}{ LOGSDON (1998) } \\
\hline \multicolumn{2}{c|}{ Padrão } & \multicolumn{2}{c|}{ CCA } & \multicolumn{2}{c}{ Padrão } & \multicolumn{2}{c}{ CCA } \\
\hline $\mathbf{f}_{\mathbf{c} 0, \mathrm{~m}}(\mathbf{M P a})$ & $\mathbf{C V ~ ( \% )}$ & $\mathbf{f}_{\mathbf{c} 0, \mathrm{~m}}(\mathrm{MPa})$ & $\mathbf{C V}(\%)$ & $\mathbf{f}_{\mathrm{c} 0, \mathrm{~m}}(\mathrm{MPa})$ & $\mathbf{C V}(\%)$ & $\mathbf{f}_{\mathrm{c} 0, \mathrm{~m}}(\mathbf{M P a})$ & $\mathbf{C V}(\%)$ \\
\hline 73,6 & 4,9 & 76,0 & 3,3 & 73,7 & 5,1 & 75,2 & 3,2 \\
\hline
\end{tabular}

TABELA 34 - Parâmetros estatísticos para resistência ao cisalhamento paralelo Copaíba

\begin{tabular}{|c|c|c|c|c|c|c|c|}
\hline \multicolumn{8}{|c|}{ Método de correção da umidade } \\
\hline \multicolumn{4}{|c|}{ NBR 7190/97 } & \multicolumn{4}{|c|}{ LOGSDON (1998) } \\
\hline \multicolumn{2}{|c|}{ Padrão } & \multicolumn{2}{|c|}{$\mathbf{C C A}$} & \multicolumn{2}{|c|}{ Padrão } & \multicolumn{2}{|c|}{$\mathbf{C C A}$} \\
\hline $\mathbf{f}_{\mathrm{v} 0, \mathrm{~m}}(\mathrm{MPa})$ & CV (\%) & $\mathbf{f}_{\mathrm{v} 0, \mathrm{~m}}(\mathrm{MPa})$ & CV (\%) & $\mathbf{f}_{\mathrm{v} 0, \mathrm{~m}}(\mathrm{MPa})$ & CV (\%) & $\mathbf{f}_{\mathrm{v} 0, \mathrm{~m}}(\mathrm{MPa})$ & CV (\%) \\
\hline 18,9 & 6,2 & 19,6 & 7,4 & 18,9 & 6,5 & 19,5 & 4,6 \\
\hline
\end{tabular}

Conforme os resultados da resistência à compressão paralela às fibras (Tabela 33), foi observado que para ambas as formas de correção da umidade, a diferença dos valores dos coeficientes de variação entre os CP's naturais e preservados foi inferior a dois pontos percentuais. Da Tabela 34, referente aos dados sobre o cisalhamento paralelo às fibras, pode ser notado que tal diferença se manteve.

Assim como para as demais espécies mencionadas, o módulo de elasticidade longitudinal de cada CP foi obtido segundo as recomendações da NBR 7190/97 Anexo B (Item 8) e através de uma regressão linear simples. Os resultados estão mostrados nas Tabelas 35 e 36. Para ilustrar, a Figura 19 traz um exemplo do módulo de elasticidade obtido através da regressão linear.

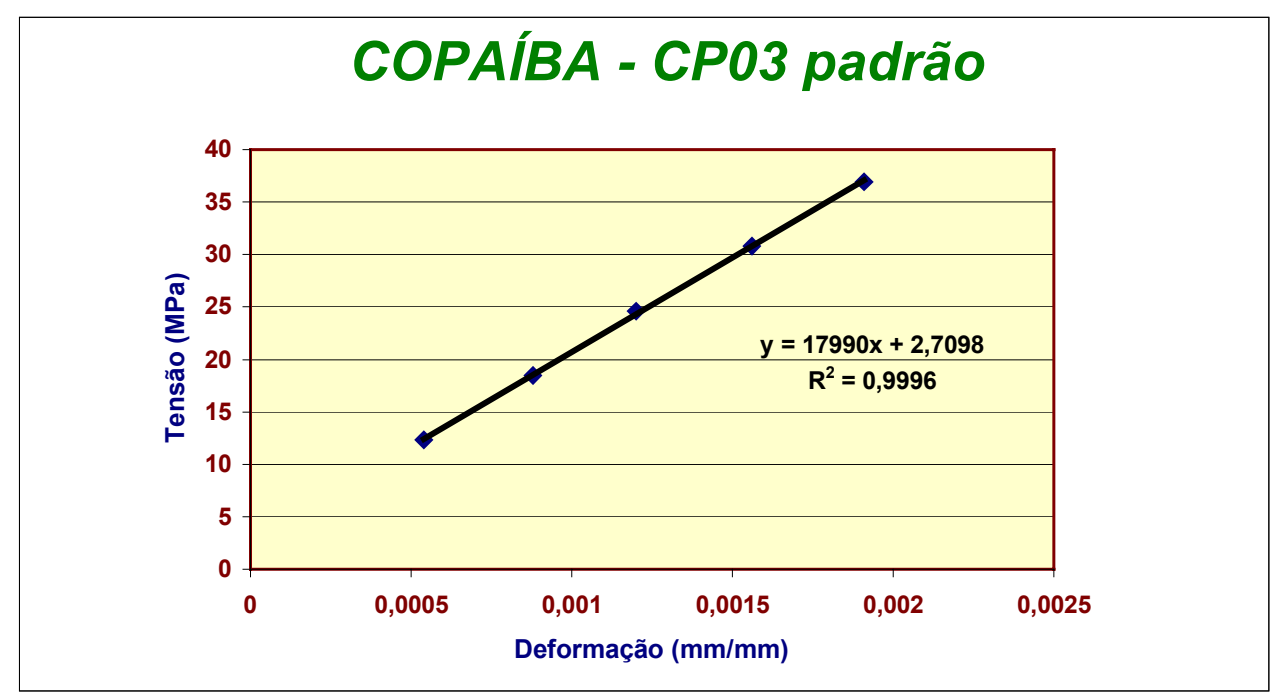

FIGURA 19 - Módulo de elasticidade longitudinal da Copaíba

(regressão linear simples)

TABELA 35 - Valores de rigidez à compressão paralela - NBR 7190/97 - Copaíba

Correção da umidade - NBR 7190/97 Padrão 


\begin{tabular}{|c|c|c|c|c|c|c|}
\hline CP & \multicolumn{6}{|c|}{ Correção da umidade - NBR 7190/97 } \\
\hline COP-01 & 15706 & 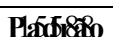 & -0.8 & 16131 & 16070 & $-0,4$ \\
\hline COP-02 & 18372 & 18331 & $-0,2$ & 21037 & 21162 & 0,6 \\
\hline $\mathrm{CQP}_{\overline{\mathbf{p}}} 03$ & 18383 & 18386 & 0,0 & 16434 & 16297 & $-0,8$ \\
\hline COP-04 & $\mathrm{E}_{\mathrm{c} 0 \mathrm{NBR}}^{6624}$ & $\mathbf{E}_{\mathrm{co} \mathrm{Regr}}^{5862}$ & $-44^{6}$ & $\mathbf{E}_{\mathrm{CO}}^{5436}$ & $\mathrm{E}_{\mathrm{co} \text { Regr }}^{4336}$ & $-7 \Delta_{1}^{1}$ \\
\hline COP-05 & (19月) & (19pota & $(\%)$ & $(10 p)$ & (1072) & $(2 \% 0$ \\
\hline COP-06 & 21449 & 20072 & $-6,4$ & 20718 & 19285 & \\
\hline
\end{tabular}

TABELA 36 - Valores de rigidez à compressão paralela - LOGSDON (1998) Copaíba

\begin{tabular}{|c|c|c|c|c|c|c|}
\hline & \multicolumn{6}{|c|}{ Correção da umidade - LOGSDON (1998) } \\
\hline & \multicolumn{3}{|c|}{ Padrão } & \multicolumn{3}{|c|}{ CCA } \\
\hline & $\begin{array}{l}\mathbf{E}_{\mathrm{c} 0, \mathrm{NBR}} \\
(\mathrm{MPa})\end{array}$ & $\begin{array}{l}\mathbf{E}_{\text {c0,Regr }} \\
(\mathrm{MPa})\end{array}$ & $\begin{array}{c}\Delta \\
(\%)\end{array}$ & $\begin{array}{l}\mathbf{E}_{\mathrm{c} 0, \mathrm{NBR}} \\
(\mathrm{MPa})\end{array}$ & $\begin{array}{l}\mathbf{E}_{\mathrm{c} 0 \text {,Regr }} \\
(\mathrm{MPa})\end{array}$ & $\begin{array}{c}\Delta \\
(\%) \\
\end{array}$ \\
\hline COP-01 & 15543 & 15425 & $-0,8$ & 15963 & 15903 & $-0,4$ \\
\hline COP-02 & 18632 & 18590 & $-0,2$ & 20940 & 21065 & 0,6 \\
\hline COP-03 & 18482 & 18485 & 0,0 & 16263 & 16127 & $-0,8$ \\
\hline COP-04 & 16530 & 15773 & $-4,6$ & 15275 & 14186 & $-7,1$ \\
\hline COP-05 & 15874 & 16565 & 4,4 & 18423 & 18057 & $-2,0$ \\
\hline COP-06 & 21856 & 20453 & $-6,4$ & 20502 & 19084 & $-6,9$ \\
\hline
\end{tabular}

A semelhança entre os valores do módulo de elasticidade longitudinal “E $\mathrm{E}_{\mathrm{c} 0, \mathrm{NBR}}$ ” e " $\mathrm{E}_{\mathrm{c} 0, \text { Regr }}$ " para os CP's preservados e naturais, levou à utilização do Teste de Dados Pareados (Pairing) para mostrar a equivalência estatística dos dados. Como exemplo de aplicação do teste será empregado o conjunto de dados dos CP's preservados e umidade corrigida segundo as sugestões de LOGSDON (1998) (Tabela 36). Assim sendo, obteve-se o seguinte intervalo de confiança da média: $-19,6 \leq \mu_{x} \leq 1000,7$. Conforme o resultado, verificou-se que tal intervalo contém o valor zero e, consequentemente, conclui-se que os conjuntos de dados são estatisticamente equivalentes. Para os demais conjuntos contidos nas Tabelas $35 \mathrm{e}$ 36, esta hipótese também foi aceita.

A partir dos dados obtidos da regressão linear, verificou-se a variabilidade do módulo de elasticidade longitudinal através da média aritmética e do coeficiente de variação (ver Tabela 37).

TABELA 37 - Parâmetros estatísticos para rigidez à compressão paralela - Copaíba

\begin{tabular}{|c|c|c|c|c|c|c|c|}
\hline \multicolumn{8}{|c|}{ Método de correção da umidade } \\
\hline \multicolumn{4}{|c|}{ NBR 7190/97 } & \multicolumn{4}{|c|}{ LOGSDON (1998) } \\
\hline \multicolumn{2}{|c|}{ Padrão } & \multicolumn{2}{|c|}{ CCA } & \multicolumn{2}{|c|}{ Padrão } & \multicolumn{2}{|c|}{ CCA } \\
\hline $\mathbf{E}_{\mathrm{c} 0, \mathrm{~m}}(\mathrm{MPa})$ & CV (\%) & $\mathbf{E}_{\mathrm{c} 0, \mathrm{~m}}(\mathrm{MPa})$ & CV (\%) & $\mathbf{E}_{\mathrm{c} 0, \mathrm{~m}}(\mathbf{M P a})$ & CV $(\%)$ & $\mathbf{E}_{\mathrm{c} 0, \mathrm{~m}}(\mathrm{MPa})$ & CV $(\%)$ \\
\hline 17496 & 9,9 & 17566 & 14,1 & 17548 & 11,1 & 17404 & 14,3 \\
\hline
\end{tabular}

Da tabela acima, constatou-se uma diferença em torno de quatro pontos percentuais entre os valores dos coeficientes de variação dos CP's naturais e 
preservados quando empregado a correção da umidade recomendada pela NBR 7190/97. Através da sugestão proposta por LOGSDON (1998) tal diferença reduziu para aproximadamente três pontos percentuais. A partir dos resultados apresentados nas Tabelas 32, 35 e 36, obteve-se a Tabela 38, cujos valores representam o quociente das propriedades de resistência e rigidez entre os CP's preservados e naturais.

TABELA 38 - Relação da resistência e da rigidez entre os CP's preservado (CCA) e os naturais (sem preservação) - Copaíba

\begin{tabular}{|c|c|c|c|c|c|c|}
\hline \multirow{2}{*}{$\mathbf{C P}$} & \multicolumn{3}{|c|}{ NBR 7190/97 } & \multicolumn{3}{|c|}{ LOGSDON (1998) } \\
\hline & $\left(\mathbf{f}_{\mathrm{c} 0, \mathrm{CCA}} / \mathbf{f}_{\mathrm{c} 0, \mathrm{p}}\right)$ & $\left(\mathbf{f}_{\mathrm{v} 0, \mathrm{CCA}} / \mathbf{f}_{\mathrm{v} 0, \mathrm{p}}\right)$ & $\left(\mathbf{E}_{\mathrm{c} 0, \mathrm{CCA}} / \mathbf{E}_{\mathrm{c} 0, \mathrm{p}}\right)_{\mathrm{Regr}}$ & $\left(\mathbf{f}_{\mathrm{c} 0, \mathrm{CCA}} / \mathbf{f}_{\mathrm{c} 0, \mathrm{p}}\right)$ & $\left(\mathbf{f}_{\mathrm{v} 0, \mathrm{CCA}} / \mathbf{f}_{\mathrm{v} 0, \mathrm{p}}\right)$ & $\left(\mathbf{E}_{\mathrm{c} 0, \mathrm{CCA}} / \mathbf{E}_{\mathrm{c} 0, \mathrm{p}}\right)_{\mathrm{Regr}}$ \\
\hline COP-01 & 1,05 & 0,99 & 1,03 & 1,05 & 1,00 & 1,03 \\
\hline COP-02 & 1,01 & 1,12 & 1,15 & 0,99 & 1,14 & 1,13 \\
\hline COP-03 & 1,01 & 1,08 & 0,89 & 0,99 & 1,10 & 0,87 \\
\hline COP-04 & 1,10 & 0,94 & 0,90 & 1,09 & 0,95 & 0,90 \\
\hline COP-05 & 1,03 & 1,11 & 1,09 & 1,03 & 1,11 & 1,09 \\
\hline COP-06 & 1,01 & 1,00 & 0,96 & 0,99 & 1,00 & 0,93 \\
\hline
\end{tabular}

Para mostrar a validade dos resultados da Tabela 38, usou-se como artifício preliminar a média aritmética e o coeficiente de variação (ver a seguir, Tabela 39).

TABELA 39 - Parâmetros estatísticos da relação da resistência e da rigidez entre os CP's preservado (CCA) e os naturais (sem preservação) - Copaíba

\begin{tabular}{|c|c|c|c|c|c|c|c|c|c|c|c|}
\hline \multicolumn{6}{|c|}{ NBR 7190/97 } & \multicolumn{6}{|c|}{ LOGSDON (1998) } \\
\hline \multicolumn{2}{|c|}{$\left(\mathbf{f}_{\mathrm{c} 0, \mathrm{CCA}} / \mathbf{f}_{\mathrm{c} 0, \mathrm{p}}\right)$} & \multicolumn{2}{|c|}{$\left(\mathbf{f}_{\mathrm{v} 0, \mathrm{CCA}} / \mathbf{f}_{\mathrm{v} 0, \mathrm{p}}\right)$} & \multicolumn{2}{|c|}{$\left(\mathbf{E}_{\mathrm{c} 0, \mathrm{CCA}} / \mathbf{E}_{\mathrm{c} 0, \mathrm{p}}\right)_{\mathrm{Regr}}$} & \multicolumn{2}{|c|}{$\left(\mathbf{f}_{\mathrm{c} 0, \mathrm{CCA}} / \mathbf{f}_{\mathbf{c} 0, \mathrm{p}}\right)$} & \multicolumn{2}{|c|}{$\left(\mathbf{f}_{\mathrm{v} 0, \mathrm{CCA}} / \mathbf{f}_{\mathrm{v} 0, \mathrm{p}}\right)$} & \multicolumn{2}{|c|}{$\left(\mathbf{E}_{\mathrm{c} 0, \mathrm{CCA}} / \mathbf{E}_{\mathrm{c} 0, \mathrm{p}}\right)_{\mathrm{Regr}}$} \\
\hline Média & $\begin{array}{l}\text { CV } \\
(\%)\end{array}$ & Média & $\begin{array}{l}\text { CV } \\
(\%)\end{array}$ & Média & $\begin{array}{l}\text { CV } \\
(\%)\end{array}$ & Média & $\begin{array}{l}\text { CV } \\
(\%)\end{array}$ & Média & $\begin{array}{l}\text { CV } \\
(\%)\end{array}$ & Média & $\begin{array}{l}C V \\
(\%)\end{array}$ \\
\hline 1,03 & 3,4 & 1,04 & 7,0 & 1,00 & 10,6 & 1,02 & 4,1 & 1,05 & 7,3 & 0,99 & 10,8 \\
\hline
\end{tabular}

Dos dados acima, para ambas as formas de correção de umidade, percebeu-se que as médias das relações das resistências e da rigidez pouco se alteraram. Além disto, dos coeficiente de variação, pode-se observar que a dispersão dos valores ao redor da média foi pequena.

$\mathrm{Na}$ compressão paralela às fibras e de acordo com a correção da umidade proposta por LOGSDON (1998), verificou-se um aumento da resistência dos CP's preservados em relação aos naturais de dois por cento e coeficientes de variação em torno de quatro por cento. Para a rigidez, praticamente não houve alteração da resistência, mas, o coeficiente de variação atingiu dez por cento. De acordo com as correção recomendada pela NBR 7190/97, a resistência aumentou três por cento, enquanto o módulo de elasticidade longitudinal não registrou alteração. Referente ao coeficiente de variação, os valores são equivalentes aos anteriores. 
Analisando os resultados do cisalhamento paralelo, notou-se um acréscimo da resistência dos CP's preservados. Tal valor chegou a quatro e cinco por cento, dependendo da maneira de correção da umidade (ver Tabela 39). O coeficiente de variação em ambos os casos ficou em torno de sete por cento.

Assim como para as demais espécies estudadas, a confiabilidade dos valores apresentados Tabela 39 também será verificada através do Teste de Dados Pareados.

Da Tabela 32 verificou-se que os conjuntos de dados referentes aos CP's tratados e naturais submetidos à compressão paralela, com correção da umidade sugerida por LOGSDON (1998) podem ser considerados equivalentes, isto é, $\left(-1,6 \leq \mu_{x} \leq 4,7\right)$. O mesmo acontece quando tal correção é realizada pela recomendação da NBR 7190/97. Veja o intervalo de confiança da média obtido, $\left(-0,1 \leq \mu_{x} \leq 4,9\right)$.

Segundo as correções de umidade mencionadas, é conveniente adotar fator igual a 1,0, ou seja, deve-se desconsiderar a influência do produto preservativo e do processo de tratamento nas propriedades de resistência à compressão paralela às fibras.

Conforme os dados das Tabelas 35 e 36, obteve-se respectivamente os seguintes intervalo de confiança: $\quad\left(-1910,3 \leq \mu_{x} \leq 2049,8\right) \quad$ e $\left(-2157,7 \leq \mu_{x} \leq 1868,1\right)$. Conforme os resultados, verificou-se estatisticamente a equivalência dos dados dos conjuntos. Em virtude disto, é conveniente considerar um fator igual a 1,0 .

Em ambas as maneiras de correção da umidade aqui mencionadas, os conjuntos de dados referentes aos CP's tratados e naturais submetidos aos ensaios de cisalhamento paralelo (ver Tabela 32) podem ser considerados equivalentes. Veja, *Correção (NBR 7190/97): $-2,2 \leq \mu_{x} \leq 0,7$;

*Correção (LOGSDON (1998)): $-1,9 \leq \mu_{x} \leq 0,8$.

Assim sendo, o fator sugerido para quantificar o efeito do produto químico e do processo de preservação sobre a resistência ao cisalhamento paralelo, deve ser igual a 1,0. Em outras palavras, pode-se dizer que não ocorre influência significativa na citada propriedade. 
De forma resumida, a Tabela 40 mostra os valores propostos a serem adotados como fatores que considerem o efeito do produto e do processo preservativo nas propriedades mecânicas da madeira.

TABELA 40 - Fator K - efeito do preservativo e do processo de tratamento nas propriedades mecânicas da madeira - Copaíba

\begin{tabular}{c|c|c|c|c|c}
\hline \multicolumn{3}{c|}{ NBR 7190/97 } & \multicolumn{3}{c}{ LOGSDON (1998) } \\
\hline$\left(\mathbf{f}_{\mathrm{c} 0, \mathrm{CCA}} / \mathbf{f}_{\mathrm{c} 0, \mathrm{p}}\right)$ & $\left(\mathbf{f}_{\mathrm{v} 0, \mathrm{CCA}} / \mathbf{f}_{\mathrm{v} 0, \mathrm{p}}\right)$ & $\left(\mathbf{E}_{\mathrm{c} 0, \mathrm{CCA}} / \mathbf{E}_{\mathrm{c} 0, \mathrm{p}}\right)_{\mathrm{Regr}}$ & $\left(\mathbf{f}_{\mathbf{c} 0, \mathrm{CCA}} / \mathbf{f}_{\mathrm{c} 0, \mathrm{p}}\right)$ & $\left(\mathbf{f}_{\mathrm{v} 0, \mathrm{CCA}} / \mathbf{f}_{\mathrm{v} 0, \mathrm{p}}\right)$ & $\left(\mathbf{E}_{\mathrm{c} 0, \mathrm{CCA}} / \mathbf{E}_{\mathrm{c} 0, \mathrm{p}}\right)_{\mathrm{Regr}}$ \\
\hline 1,0 & 1,0 & 1,0 & 1,0 & 1,0 & 1,0 \\
\hline
\end{tabular}

\subsubsection{Jatobá (Hymenaea sp)}

Os ensaios de compressão paralela às fibras para os CP's naturais e preservados foram realizados com uma umidade média de aproximadamente 11,3 e 10,9\%, respectivamente. Para os CP's naturais e preservados submetidos aos ensaios de cisalhamento paralelo, o teor de umidade médio foi de 11,9 e 11,8\%, respectivamente.

A partir das correções da umidade conforme NBR 7190/97 e LOGSDON (1998), os resultados referentes a resistência característica à compressão paralela às fibras dos CP's naturais são iguais a $86,2 \mathrm{MPa}$ e $85,1 \mathrm{MPa}$, enquanto para os CP's impregnados foram obtidos valores iguais a $85,9 \mathrm{MPa}$ e $85,0 \mathrm{MPa}$, respectivamente. Devido a correção sugerida pela NBR 7190/97, verificou-se um acréscimo em torno de $1,3 \%$ relativo aos CP's naturais e de $1,0 \%$ para os preservados. Desta forma, para ambas as situações, os resultados alcançados classificam a amostra como classe C60.

Foi verificado, para ambas as formas de correções da umidade, uma pequena redução dos valores das resistências características dos CP's preservados em relação aos naturais. Para a correção proposta de LOGSDON (1998), tal redução atingiu 0,2\%, enquanto pela recomendação da NBR 7190/97 chegou a $0,4 \%$.

Dos ensaios de cisalhamento paralelo às fibras foram obtidos para os CP's não preservados, valores de resistências características iguais a 19,5MPa (NBR 7190/97) e 19,4MPa (LOGSDON (1998)) e, para os CP's preservados obteve-se respectivamente, 18,3MPa e 18,3MPa. Através das recomendações da NBR 7190/97, a resistência característica estimada para a amostra sem tratamento preservativo foi aproximadamente $0,6 \%$ superior, enquanto para os CP's preservados, praticamente não houve diferença. 
Comparando as resistências características obtidas através de ambas as formas de correção de umidade aqui mencionadas, foi observado uma redução em torno $6,5 \%$ por parte dos CP's preservados.

A Tabela 41 apresenta de forma resumida os valores discutidos acima.

TABELA 41 - Resistência característica à compressão e ao cisalhamento paralelo Jatobá

\begin{tabular}{|c|c|c|c|c|c|c|c|}
\hline \multicolumn{4}{|c|}{ Resistência à compressão paralela } & \multicolumn{4}{|c|}{ Resistência ao cisalhamento paralelo } \\
\hline \multicolumn{2}{|c|}{ NBR 7190/97 } & \multicolumn{2}{|c|}{ LOGSDON (1998) } & \multicolumn{2}{|c|}{ NBR 7190/97 } & \multicolumn{2}{|c|}{ LOGSDON (1998) } \\
\hline $\begin{array}{c}\mathbf{f}_{\mathrm{c} 0, \mathrm{k}, \mathrm{p}} \\
(\mathrm{MPa})\end{array}$ & $\begin{array}{l}\mathbf{f}_{\mathrm{c} 0, \mathrm{k}, \mathrm{CCA}} \\
(\mathrm{MPa})\end{array}$ & $\begin{array}{c}\mathbf{f}_{\mathrm{c} 0, \mathrm{k}, \mathrm{p}} \\
\text { (MPa) }\end{array}$ & $\begin{array}{l}\mathbf{f}_{\mathrm{c} 0, \mathrm{k}, \mathrm{CCA}} \\
\text { (MPa) }\end{array}$ & $\begin{array}{c}\mathbf{f}_{\mathrm{v} 0, \mathbf{k}, \mathbf{p}} \\
(\mathrm{MPa})\end{array}$ & $\begin{array}{l}\mathbf{f}_{\mathrm{v} 0, \mathrm{k}, \mathrm{CCA}} \\
\text { (MPa) }\end{array}$ & $\begin{array}{l}\mathbf{f}_{\mathrm{v} 0, \mathrm{k}, \mathrm{p}} \\
(\mathrm{MPa})\end{array}$ & $\begin{array}{l}\mathbf{f}_{\mathrm{v} 0, \mathrm{k}, \mathrm{CCA}} \\
(\mathrm{MPa})\end{array}$ \\
\hline 86,2 & 85,9 & 85,1 & 85,0 & 19,5 & 18,3 & 19,4 & 18,3 \\
\hline
\end{tabular}

Os valores característicos apresentados na tabela acima foram calculados a partir dos resultados individuais mostrados na Tabela 42, cujo valor médio da massa específica aparente $\left(\rho_{12} \%\right)$ é de $0,96 \mathrm{~g} / \mathrm{cm}^{3}$. Esta média foi obtida a partir de cada valor individual corrigido para a umidade de 12\%, através do diagrama de Kollmann.

TABELA 42 - Valores de resistência à compressão e ao cisalhamento paralelo Jatobá

\begin{tabular}{c|c|c|c|c|c|c|c|c}
\hline \multirow{2}{*}{ CP } & \multicolumn{2}{|c|}{ Resistência à compressão paralela } & \multicolumn{3}{c}{ Resistência ao cisalhamento paralelo } \\
\cline { 2 - 9 } & $\begin{array}{c}\text { NBR 7190/97 } \\
\text { (MPa) }\end{array}$ & \multicolumn{2}{c|}{$\begin{array}{c}\text { LOGSDON (1998) } \\
\text { (MPa) }\end{array}$} & \multicolumn{2}{c}{$\begin{array}{c}\text { NBR 7190/97 } \\
\text { (MPa) }\end{array}$} & \multicolumn{2}{c}{$\begin{array}{c}\text { LOGSDON (1998) } \\
\text { (MPa) }\end{array}$} \\
\cline { 2 - 9 } & Padrão & CCA & Padrão & CCA & Padrão & CCA & Padrão & CCA \\
\hline JAT-01 & 91,0 & 82,0 & 91,0 & 81,8 & 17,9 & 18,6 & 17,8 & 18,5 \\
JAT-02 & 85,5 & 80,3 & 85,5 & 80,0 & 25,0 & 23,5 & 24,9 & 23,6 \\
JAT-03 & 90,7 & 81,5 & 90,3 & 81,4 & 19,5 & 19,8 & 19,5 & 19,8 \\
JAT-04 & 81,2 & 78,7 & 80,7 & 78,0 & 28,5 & 28,9 & 28,5 & 28,9 \\
JAT-05 & 92,7 & 88,3 & 92,3 & 87,0 & 19,6 & 17,9 & 19,7 & 17,9 \\
JAT-06 & 82,6 & 79,7 & 82,2 & 79,2 & 24,2 & 21,3 & 24,3 & 21,3 \\
\hline
\end{tabular}

De modo que tenha o respaldo estatístico, os dados contidos na Tabela 42 serão expressos a partir da média aritmética e do coeficiente de variação (ver Tabelas 43 e 44$)$.

TABELA 43 - Parâmetros estatísticos para resistência à compressão paralela Jatobá

\begin{tabular}{|c|c|c|c|c|c|c|c|}
\hline \multicolumn{8}{|c|}{ Método de correção da umidade } \\
\hline \multicolumn{4}{|c|}{ NBR 7190/97 } & \multicolumn{4}{|c|}{ LOGSDON (1998) } \\
\hline \multicolumn{2}{|c|}{ Padrão } & \multicolumn{2}{|c|}{ CCA } & \multicolumn{2}{|c|}{ Padrão } & \multicolumn{2}{|c|}{ CCA } \\
\hline $\mathrm{f}_{\mathrm{c} 0, \mathrm{~m}}(\mathrm{MPa})$ & CV (\%) & $\mathrm{f}_{\mathrm{c} 0, \mathrm{~m}}(\mathrm{MPa})$ & CV (\%) & $\mathrm{f}_{\mathrm{c} 0, \mathrm{~m}}$ (MPa) & CV (\%) & $\mathrm{f}_{\mathrm{c} 0, \mathrm{~m}}(\mathrm{MPa})$ & CV (\%) \\
\hline 87,3 & 5,5 & 81,8 & 4,2 & 87,0 & 5,6 & 81,2 & 3,9 \\
\hline
\end{tabular}


TABELA 44 - Parâmetros estatísticos para resistência ao cisalhamento paralelo Jatobá

\begin{tabular}{|c|c|c|c|c|c|c|c|}
\hline \multicolumn{8}{|c|}{ Método de correção da umidade } \\
\hline \multicolumn{4}{|c|}{ NBR 7190/97 } & \multicolumn{4}{|c|}{ LOGSDON (1998) } \\
\hline \multicolumn{2}{|c|}{ Padrão } & \multicolumn{2}{|c|}{ CCA } & \multicolumn{2}{|c|}{ Padrão } & \multicolumn{2}{|c|}{ CCA } \\
\hline $\mathrm{f}_{\mathrm{v} 0, \mathrm{~m}}(\mathrm{MPa})$ & CV (\%) & $\mathrm{f}_{\mathrm{v} 0, \mathrm{~m}}(\mathrm{MPa})$ & CV (\%) & $\mathbf{f}_{\mathrm{v} 0, \mathrm{~m}}(\mathrm{MPa})$ & CV (\%) & $\mathrm{f}_{\mathrm{v} 0, \mathrm{~m}}(\mathrm{MPa})$ & CV (\%) \\
\hline 22,5 & 18,4 & 21,7 & 18,8 & 22,5 & 18,2 & 21,7 & 18,9 \\
\hline
\end{tabular}

Conforme os resultados da Tabela 43, foi observado que para ambas as formas de correção da umidade, a diferença dos valores dos coeficientes de variação entre os CP's naturais e preservados foi inferior a dois pontos percentuais. Referente aos dados sobre o cisalhamento paralelo às fibras (Tabela 44), pode ser notado que tal diferença não ultrapassou um ponto percentual. Desta forma, admite-se os resultados não foram influenciados de maneira relevante devido a anisotropia do material.O módulo de elasticidade longitudinal de cada CP também foi obtido segundo as recomendações da NBR 7190/97 - Anexo B (Item 8) e através de uma regressão linear simples. Os resultados estão mostrados nas Tabelas 45 e 46. Para ilustrar, a Figura 20 traz um exemplo do módulo de elasticidade obtido através da regressão linear.

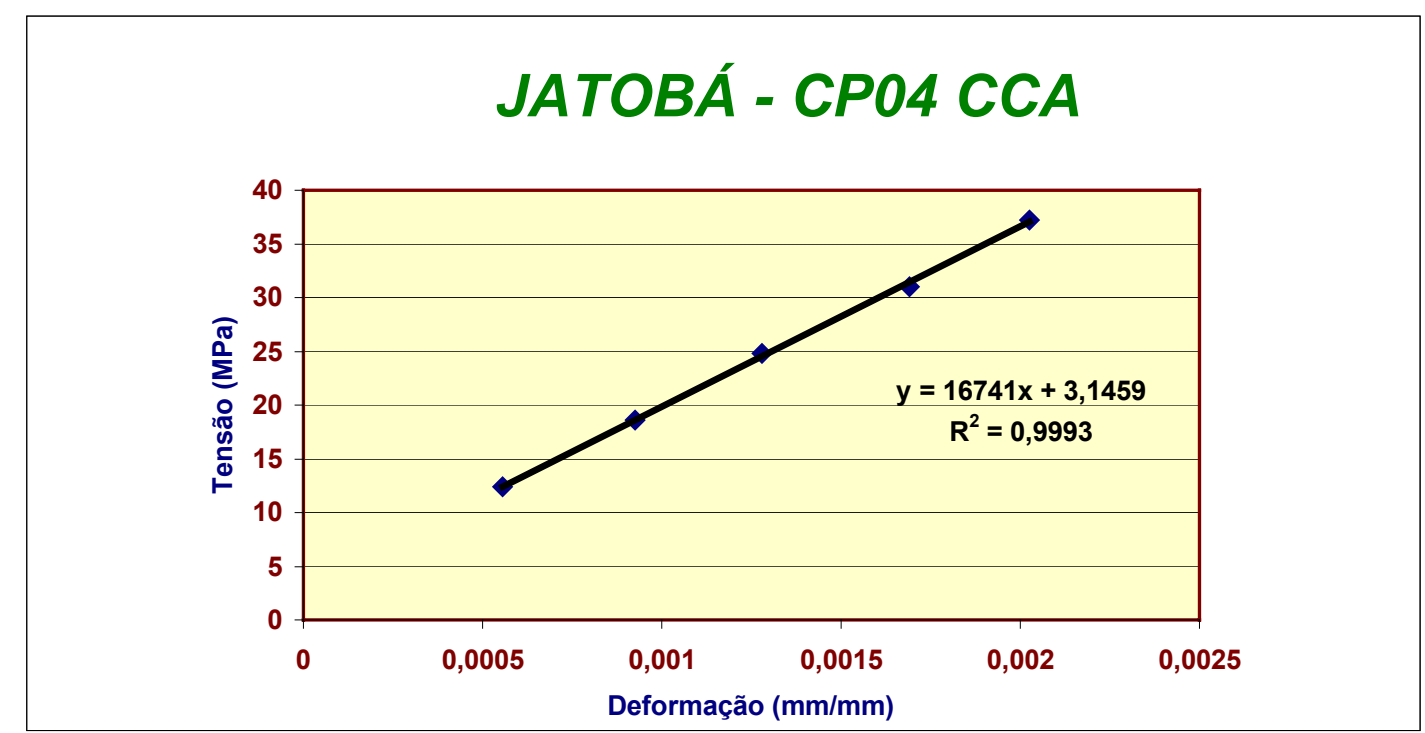

FIGURA 20 - Módulo de elasticidade longitudinal do Jatobá (regressão linear simples) 
TABELA 45 - Valores de rigidez à compressão paralela - NBR 7190/97 - Jatobá

\begin{tabular}{|c|c|c|c|c|c|c|}
\hline \multirow[b]{3}{*}{$\mathbf{C P}$} & \multicolumn{6}{|c|}{ Correção da umidade - NBR 7190/97 } \\
\hline & \multicolumn{3}{|c|}{ Padrão } & \multicolumn{3}{|c|}{ CCA } \\
\hline & $\begin{array}{l}\mathrm{E}_{\mathrm{c0}, \mathrm{NBR}} \\
(\mathrm{MPa})\end{array}$ & $\begin{array}{l}\mathbf{E}_{\text {c0,Regr }} \\
\text { (MPa) }\end{array}$ & $\begin{array}{c}\Delta \\
(\%)\end{array}$ & $\begin{array}{l}\mathrm{E}_{\mathrm{c} 0, \mathrm{NBR}} \\
(\mathrm{MPa})\end{array}$ & $\begin{array}{l}\mathbf{E}_{\mathrm{c} 0 \text {,Regr }} \\
(\mathrm{MPa})\end{array}$ & $\begin{array}{c}\Delta \\
(\%)\end{array}$ \\
\hline JAT-01 & 19580 & 18791 & $-4,0$ & 19089 & 18217 & $-4,6$ \\
\hline JAT-02 & 16595 & 16560 & $-0,2$ & 17130 & 16034 & $-6,4$ \\
\hline JAT-03 & 22234 & 20898 & $-6,0$ & 19446 & 19285 & $-0,8$ \\
\hline JAT-04 & 18253 & 18137 & $-0,6$ & 16444 & 16172 & $-1,7$ \\
\hline JAT-05 & 22246 & 21943 & $-1,4$ & 20667 & 20731 & 0,7 \\
\hline JAT-06 & 18767 & 17922 & $-4,5$ & 17136 & 16851 & $-2,7$ \\
\hline
\end{tabular}

TABELA 46 - Valores de rigidez à compressão paralela - LOGSDON (1998) Jatobá

\begin{tabular}{c|c|c|c|c|c|c}
\hline & \multicolumn{5}{|c}{ Correção da umidade - LOGSDON (1998) } \\
\cline { 2 - 7 } Cadrão & \multicolumn{3}{|c}{ Pad } \\
\cline { 2 - 7 } CP & $\mathbf{E}_{\mathbf{c 0 , N B R}}$ & $\mathbf{E}_{\mathbf{c 0 , \text { Regr }}}$ & $\begin{array}{c}\Delta \\
(\mathbf{M P a})\end{array}$ & $\begin{array}{c}\mathbf{E}_{\mathbf{c 0 , N B R}} \\
\mathbf{( \% )}\end{array}$ & $\begin{array}{c}\mathbf{E}_{\mathbf{c 0 , R e g r}} \\
\mathbf{( M P a )}\end{array}$ & $\begin{array}{c}\Delta \\
(\mathbf{M P a})\end{array}$ \\
\hline JAT-01 & 19580 & 18791 & $-4,0$ & 19050 & 18180 & $-4,6$ \\
JAT-02 & 16595 & 16560 & $-0,2$ & 17051 & 15961 & $-6,4$ \\
JAT-03 & 22014 & 20691 & $-6,0$ & 20095 & 19928 & $-0,8$ \\
JAT-04 & 18131 & 18016 & $-0,6$ & 16299 & 16030 & $-1,7$ \\
JAT-05 & 22156 & 21854 & $-1,4$ & 20372 & 20515 & 0,7 \\
JAT-06 & 18671 & 17831 & $-4,5$ & 17040 & 16756 & $-2,7$ \\
\hline
\end{tabular}

Os valores dos módulos de elasticidade longitudinal " $\mathrm{E}_{\mathrm{c} 0, \mathrm{NBR}}$ " e " $\mathrm{E}_{\mathrm{c} 0 \text {,Regr }}$ " determinados para os CP's preservados e naturais, levou à utilização do Teste de Dados Pareados (Pairing) para mostrar a possível equivalência estatística dos mesmos.

Para exemplificar a aplicação do citado teste, foi utilizado o conjunto de dados dos CP's preservados e umidade corrigida segundo as sugestões de LOGSDON (1998) (Tabela 46). A partir daí, obteve-se o seguinte intervalo de confiança: $-63,5 \leq \mu_{x} \leq 909,1$. Pode-se verificar que tal intervalo contém o valor zero e, consequentemente, os conjuntos de dados podem ser considerados estatisticamente equivalentes. O mesmo foi observado para os demais conjuntos contidos nas Tabelas 45 e 46. Assim como nas espécies citadas, expressou-se o módulo de elasticidade longitudinal através da média aritmética e do coeficiente de variação (ver Tabela 47.

TABELA 47 - Parâmetros estatísticos para rigidez à compressão paralela - Jatobá

\begin{tabular}{|c|c|c|c|c|c|c|c|}
\hline \multicolumn{8}{|c|}{ Método de correção da umidade } \\
\hline \multicolumn{4}{|c|}{ NBR 7190/97 } & \multicolumn{4}{|c|}{ LOGSDON (1998) } \\
\hline \multicolumn{2}{|c|}{ Padrão } & \multicolumn{2}{|c|}{ CCA } & \multicolumn{2}{|c|}{ Padrão } & \multicolumn{2}{|c|}{ CCA } \\
\hline $\mathbf{E}_{\mathrm{c} 0, \mathrm{~m}}(\mathbf{M P a})$ & CV (\%) & $\mathrm{E}_{\mathrm{c} 0, \mathrm{~m}}(\mathrm{MPa})$ & CV (\%) & $\mathbf{E}_{\mathrm{c} 0, \mathrm{~m}}(\mathrm{MPa})$ & CV (\%) & $\mathbf{E}_{\mathrm{c} 0, \mathrm{~m}}(\mathrm{MPa})$ & CV (\%) \\
\hline 19042 & 10,5 & 17882 & 10,5 & 18957 & 10,4 & 17895 & 11,1 \\
\hline
\end{tabular}


Da tabela acima, pode-se perceber que independentemente do modo de correção da umidade, a diferença entre os valores dos coeficientes de variação dos CP's preservados e sem preservação não atingiu um ponto percentual.

A partir dos resultados apresentados nas Tabelas 42, 45 e 46, obteve-se a Tabela 48, cujos valores representam o quociente das propriedades de resistência e rigidez entre os CP's preservados e naturais.

TABELA 48 - Relação da resistência e da rigidez entre os CP's preservado (CCA) e os naturais (sem preservação) - Jatobá

\begin{tabular}{c|c|c|c|c|c|c}
\hline \multirow{2}{*}{$\mathbf{C P}$} & \multicolumn{3}{|c|}{ NBR 7190/97 } & \multicolumn{3}{c}{ LOGSDON (1998) } \\
\cline { 2 - 7 } & $\left(\mathbf{f}_{\mathbf{c} 0, \mathbf{C C A}} / \mathbf{f}_{\mathbf{c 0}, \mathbf{p}}\right)$ & $\left(\mathbf{f}_{\mathbf{v 0}, \mathbf{C C A}} / \mathbf{f}_{\mathbf{v 0}, \mathbf{p}}\right)$ & $\left(\mathbf{E}_{\mathbf{c 0}, \mathbf{C C A}} / \mathbf{E}_{\mathbf{c 0}, \mathbf{p}}\right)_{\mathbf{R e g r}}$ & $\left(\mathbf{f}_{\mathbf{c 0}, \mathbf{C C A}} / \mathbf{f}_{\mathbf{c 0}, \mathbf{p}}\right)$ & $\left(\mathbf{f}_{\mathbf{v 0}, \mathbf{C C A}} / \mathbf{f}_{\mathbf{v 0}, \mathbf{p}}\right)$ & $\left(\mathbf{E}_{\mathbf{c 0}, \mathbf{C C A}} / \mathbf{E}_{\mathbf{c 0}, \mathbf{p}}\right)_{\mathbf{R e g r}}$ \\
\hline JAT-01 & 0,90 & 1,04 & 0,97 & 0,90 & 1,04 & 0,97 \\
JAT-02 & 0,94 & 0,94 & 0,97 & 0,94 & 0,95 & 0,96 \\
JAT-03 & 0,90 & 1,02 & 0,92 & 0,90 & 1,01 & 0,96 \\
JAT-04 & 0,97 & 1,01 & 0,89 & 0,97 & 1,01 & 0,89 \\
JAT-05 & 0,95 & 0,91 & 0,95 & 0,94 & 0,91 & 0,94 \\
JAT-06 & 0,97 & 0,88 & 0,94 & 0,96 & 0,88 & 0,94 \\
\hline
\end{tabular}

De modo preliminar, a validade dos resultados da Tabela 48 pode ser comprovada através dos dados estatísticos apresentados na Tabela 49.

TABELA 49 - Parâmetros estatísticos da relação da resistência e da rigidez entre os CP's preservado (CCA) e os naturais (sem preservação) - Jatobá

\begin{tabular}{|c|c|c|c|c|c|c|c|c|c|c|c|}
\hline \multicolumn{6}{|c|}{ NBR 7190/97 } & \multicolumn{6}{|c|}{ LOGSDON (1998) } \\
\hline$\left(\mathbf{f}_{\mathrm{c} 0, \mathrm{C}}\right.$ & $c 0, p)$ & $\left(\mathbf{f}_{\mathrm{v} 0, \mathrm{CC}}\right.$ & $\overline{\left.f_{v 0}, p\right)}$ & $\left(\mathrm{E}_{\mathrm{c} 0, \mathrm{c}}\right.$ & & $\left(\mathbf{f}_{\mathrm{c} 0, \mathrm{CCA}}\right.$ & $\left.\mathbf{f}_{\mathbf{c} 0, \mathrm{p}}\right)$ & $\left(\mathbf{f}_{\mathrm{v} 0, \mathrm{CC} A}\right.$ & $\left.f_{\mathbf{v} 0, p}\right)$ & $\left(\mathbf{E}_{\mathrm{c} 0, \mathrm{c}}\right.$ & p) $)_{\text {Regr }}$ \\
\hline Média & $\begin{array}{l}\text { CV } \\
(\%)\end{array}$ & Média & $\begin{array}{l}\text { CV } \\
(\%)\end{array}$ & dia & $\begin{array}{l}\text { CV } \\
(\%)\end{array}$ & Média & $\begin{array}{l}\text { CV } \\
(\%)\end{array}$ & Média & $\begin{array}{l}\text { CV } \\
(\%)\end{array}$ & édia & $\begin{array}{l}\text { CV } \\
(\%)\end{array}$ \\
\hline$\overline{0,94}$ & 3,3 & 0,97 & 6,7 & 94 & 3,1 & 0,94 & 3,1 & & 6,8 & 94 & 3,1 \\
\hline
\end{tabular}

Da tabela acima, percebeu-se que as médias das relações das resistências e da rigidez não se alteraram, independentemente das formas de correção de umidade. Além disto, os coeficientes de variação obtidos foram baixos, o que significa pouca dispersão em relação aos valores médios.

Na compressão paralela às fibras e de acordo com a correção da umidade prescrita pela NBR 7190/97 verificou-se uma redução da resistência dos CP's preservados em relação aos naturais de seis por cento e coeficientes de variação inferior a quatro por cento. Para a rigidez, a redução foi de três por cento, para um coeficiente de variação em torno de sete por cento. De acordo com a correção 
proposta por LOGSDON (1998), tanto a resistência quanto a rigidez se equivalem aos valores anteriores.

Analisando os resultados do cisalhamento paralelo, notou-se um decréscimo da resistência dos CP's preservados em aproximadamente três por cento, independente da maneira de correção da umidade. O coeficiente de variação em ambos os casos ficou abaixo dos sete pontos percentuais.

Por motivos já discutidos, a confiabilidade dos valores apresentados Tabela 49 também será verificada através do Teste de Dados Pareados.

Da Tabela 42 verificou-se que os conjuntos de dados referentes aos CP's tratados e naturais submetidos à compressão paralela, com correção da umidade recomendada pela NBR 7190/97 e sugerida por LOGSDON (1998), apresentou os seguintes intervalos de confiança da média, respectivamente: $\left(2,5 \leq \mu_{x} \leq 8,6\right)$ e $\left(2, \leq \mu_{x} \leq 8,7\right)$. A partir dos resultados verifica-se que o valor zero não está contido em ambos os intervalos mencionados, portanto tais conjuntos de dados não podem ser considerados estatisticamente equivalentes. Desta maneira, em ambos os casos é conveniente adotar um fator que considere a influência do produto preservativo e do processo de tratamento nas propriedades de resistência à compressão paralela às fibras. Este fator poderá ser igual aos valores médios explicitados na Tabela 49, ou seja 0,94 .

Conforme os dados das Tabela 45 e 46, obteve-se respectivamente os seguintes intervalo de confiança: $\left(564,9 \leq \mu_{x} \leq 1755,5\right)$ e $\left(499,5 \leq \mu_{x} \leq 1624,8\right)$. Assim sendo, deve-se desconsiderar a equivalência dos dados dos conjuntos. Em virtude disto, é conveniente adotar um fator igual a 0,94 .

Para as maneiras de correção da umidade aqui mencionadas, foi constatado que os conjuntos de dados referentes aos CP's tratados e naturais submetidos aos ensaios de cisalhamento paralelo (ver Tabela 42) são equivalentes. Esta conclusão se deu através dos seguintes resultados: correção (NBR 7190/97): $-0,7 \leq \mu_{x} \leq 2,3$; correção (LOGSDON (1998)): $-0,8 \leq \mu_{x} \leq 2,3$. Desta forma, admite-se que não ocorre influência significativa sobre a resistência ao cisalhamento paralelo às fibras, devida ao efeito do produto químico e do processo de preservação. Por isso, o fator sugerido para quantificar tal efeito deve ser igual a 1,0 . 
Em resumo, a Tabela 50 mostra os valores propostos a serem adotados como fatores que considerem o efeito do produto e do processo preservativo nas propriedades mecânicas da madeira.

TABELA 50 - Fator $\mathrm{K}$ - efeito do preservativo e do processo de tratamento nas propriedades mecânicas da madeira - Jatobá

\begin{tabular}{|c|c|c|c|c|c|}
\hline \multicolumn{3}{|c|}{ NBR 7190/97 } & \multicolumn{3}{|c|}{ LOGSDON (1998) } \\
\hline$\left(\mathbf{f}_{\mathrm{c} 0, \mathrm{CCA}} / \mathbf{f}_{\mathrm{c} 0, \mathrm{p}}\right)$ & $\left(\mathbf{f}_{\mathrm{v} 0, \mathrm{CCA}} / \mathbf{f}_{\mathrm{v} 0, \mathrm{p}}\right)$ & $\left(\mathbf{E}_{\mathrm{c} 0, \mathrm{CCA}} / \mathbf{E}_{\mathrm{c} 0, \mathrm{p}}\right)_{\mathrm{Regr}}$ & $\left(\mathbf{f}_{\mathrm{c} 0, \mathrm{CCA}} / \mathbf{f}_{\mathrm{c} 0, \mathrm{p}}\right)$ & $\left(\mathbf{f}_{\mathrm{v} 0, \mathrm{CCA}} / \mathbf{f}_{\mathrm{v} 0, \mathrm{p}}\right)$ & $\left(\mathbf{E}_{\mathrm{c} 0, \mathrm{CCA}} / \mathbf{E}_{\mathrm{c} 0, \mathrm{p}}\right)_{\mathrm{Regr}}$ \\
\hline 0,94 & 1,0 & 0,94 & 0,94 & 1,0 & 0,94 \\
\hline
\end{tabular}




\subsubsection{Espécies de reflorestamento}

As espécies de reflorestamento consideradas nesta pesquisa são: Eucalipto Grandis (Eucalyptus grandis) e Pinus Elliottii (Pinus elliottii).

\subsubsection{Eucalipto Grandis (Eucalyptus grandis)}

O desenvolvimento dos ensaios referentes a espécie em questão, foram empregadas duas amostras (01 e 02), obtidas de lotes distintos. A primeira, composta por seis CP's e a segunda amostra por 12. Vale lembrar que, a amostra 01 foi ensaiada com CP's naturais e impregnados com preservativo tipo CCA. Para a amostra 02, ensaiou-se CP's naturais e preservados com CCA e CCB.

A amostra 01 foi ensaiada à compressão paralela, para os CP's naturais e preservados, com uma umidade média de aproximadamente 14,5 e 15,5\%, respectivamente. Para os CP's naturais e preservados submetidos aos ensaios de cisalhamento paralelo, o teor de umidade médio foi de 14,2 e 15,3\%, respectivamente. Os ensaios à compressão paralela da amostra 02 foram realizados, para os CP's naturais e preservados com CCA e CCB, com uma umidade média de aproximadamente 12,5; 14,0 e 13,0\% respectivamente. Em contrapartida, o teor de umidade médio dos CP's naturais e preservados com CCA e CCB submetidos aos ensaios de cisalhamento paralelo foi de 12,$1 ; 13,8$ e 13,1\%, respectivamente.

$\mathrm{Na}$ amostra 01, a preservação foi realizada em seis CP's de compressão paralela e seis CP's de cisalhamento paralelo às fibras. Como resultado, foram obtidas retenções médias iguais a $10,1 \mathrm{~kg} / \mathrm{m}^{3}$ e $9,8 \mathrm{~kg} / \mathrm{m}^{3}$, respectivamente. Para a amostra 02, a preservação foi realizada em 12 CP's de compressão paralela e 12 CP's de cisalhamento paralelo às fibras, tanto com CCA quanto com CCB. O tratamento com CCA gerou retenções médias iguais a $10,3 \mathrm{~kg} / \mathrm{m}^{3}(\mathrm{CP}$ 's de compressão paralela) e $10,0 \mathrm{~kg} / \mathrm{m}^{3}$ (CP's de cisalhamento paralelo), enquanto para impregnação com CCB foram obtidos $41,2 \mathrm{~kg} / \mathrm{m}^{3}$ e $40,7 \mathrm{~kg} / \mathrm{m}^{3}$, respectivamente.

Assim como nas espécies nativas, os valores da resistência e da rigidez de cada CP ensaiado serão corrigidos em função da umidade. Tal correção será dada através do emprego da expressão recomendada pela NBR 7190/97, bem como daquela sugerida por LOGSDON (1998). 
Dos ensaios realizados à compressão paralela às fibras para os CP's naturais da amostra 01, levaram aos resultados das resistências características iguais a $53,7 \mathrm{MPa}$ e 54,0MPa, referente aos métodos de correção da umidade expostos pela NBR 7190/97 e por LOGSDON (1998), respectivamente. Para a mesma amostra, os CP's tratados atingiram valores iguais a $64,3 \mathrm{MPa}$ e $65,5 \mathrm{MPa}$. Devido a correção sugerida por LOGSDON (1998), para os CP's naturais, verificou-se um acréscimo inferior a $1,0 \%$, enquanto para os preservados, o acréscimo foi de 1,8\%. Portanto, a partir dos resultados alcançados, pode-se definir a amostra 01 (natural) como classe C-40, enquanto a amostra 01 (preservada) é classificada como classe C-60.

Comparando os resultados anteriores, foi constatado um acréscimo acentuado dos valores das resistências características dos CP's preservados em relação aos naturais. Para a correção proposta pela NBR 7190/97 tal aumento atingiu 19,8\%, enquanto a recomendação de LOGSDON (1998) levou a 21,2\%.

Para os CP's não preservados da amostra 01, submetidos ao cisalhamento paralelo às fibras, obtiveram-se valores de resistências características iguais a 9,7MPa (NBR 7190/97) e 9,6MPa (LOGSDON (1998)). Todavia, as resistências características dos CP's preservados atingiram 12,0MPa e 11,9MPa, respectivamente. Através das recomendações da NBR 7190/97, a resistência característica estimada para a amostra sem tratamento preservativo foi aproximadamente $1,4 \%$ superior, enquanto para os CP's preservados, a diferença foi de $1,1 \%$.

Comparando as resistências características ao cisalhamento dos CP's preservados e naturais, obtidas através de ambas as formas de correção de umidade, foi observado um aumento em torno $23,6 \%$ por parte dos CP's preservados.

No que diz respeito a amostra 02 , as resistências características à compressão paralela às fibras dos CP's naturais são iguais a 64,1MPa (segundo a NBR 7190/97) e 66,2MPa (segundo LOGSDON (1998)). Em contrapartida, os CP's impregnados com CCA atingiram valores iguais a $63,8 \mathrm{MPa}$ e $65,7 \mathrm{MPa}$, enquanto os tratados com CCB chegaram a 71,0MPa e 73,1MPa, considerando as correções da umidade de acordo com a NBR 7190/97 e LOGSDON (1998), respectivamente. Diante dos resultados, pode-se perceber que tais valores levaram a um acréscimo de aproximadamente 3,0\%, por parte da correção de LOGSDON (1998). 
Neste caso, tanto os CP's naturais quanto os preservados são classificados como classe C-60.

A partir dos resultados expostos acima, foi verificado uma redução do valor da resistência característica dos CP's preservados com CCA em relação aos naturais em um patamar inferior a 1\%. Porém, para os CP's preservados com CCB, houve um acréscimo em torno de $10,5 \%$.

Dos ensaios de cisalhamento paralelo às fibras foram obtidos para os CP's não preservados, valores de resistências características iguais a $11,7 \mathrm{MPa}$ (NBR 7190/97) e 11,4MPa (LOGSDON (1998)). Para os CP's preservados obtiveram-se os seguintes resultados:

*CCA - 11,1MPa (NBR 7190/97) e 11,0MPa (LOGSDON (1998));

*CCB - 10,7MPa (NBR 7190/97) e 10,4MPa (LOGSDON (1998)).

A resistência característica para a amostra sem tratamento preservativo foi aproximadamente 3,5\% superior, quando estimada através das recomendações da NBR 7190/97. Para os CP's preservados com CCA a diferença não alcançou 1\%, enquanto os impregnados com CCB atingiu 2,9\%.

Comparando as resistências características obtidas através de ambas as formas de correção de umidade, foi constatado uma redução por parte dos CP's preservados. Usando as correções da umidade prescritas na NBR 7190/97, tal redução foi de 5,5\% quando empregado produto tipo CCA e 9,1\% para CCB. De acordo com LOGSDON (1998), obteve-se as seguintes reduções: 3,1\% (CCA) e $8,8 \%$ (CCB).

As Tabelas 51 e 52 apresentam de forma resumida os valores já discutidos.

TABELA 51- Resistência característica à compressão e ao cisalhamento paralelo (amostra 01) - Eucalipto Grandis

\begin{tabular}{|c|c|c|c|c|c|c|c|}
\hline \multicolumn{4}{|c|}{ Resistência à compressão paralela } & \multicolumn{4}{|c|}{ Resistência ao cisalhamento paralelo } \\
\hline \multicolumn{2}{|c|}{ NBR 7190/97 } & \multicolumn{2}{|c|}{ LOGSDON (1998) } & \multicolumn{2}{|c|}{ NBR 7190/97 } & \multicolumn{2}{|c|}{ LOGSDON (1998) } \\
\hline $\begin{array}{c}\mathbf{f}_{\mathbf{c 0 , k}, \mathbf{p}} \\
(\mathbf{M P a})\end{array}$ & $\begin{array}{l}\mathbf{f}_{\mathrm{c} 0, \mathrm{k}, \mathrm{CCA}} \\
(\mathrm{MPa})\end{array}$ & $\begin{array}{c}\mathbf{f}_{\mathbf{c 0 , k}, \mathrm{p}} \\
(\mathrm{MPa})\end{array}$ & $\begin{array}{l}\mathbf{f}_{\mathrm{c} 0 \mathrm{k}, \mathrm{kCA}} \\
(\mathrm{MPa})\end{array}$ & $\begin{array}{l}\mathbf{f}_{\mathrm{v} \mathbf{0}, \mathrm{k}, \mathrm{p}} \\
(\mathrm{MPa})\end{array}$ & $\begin{array}{l}\mathbf{f}_{\mathrm{v} 0, \mathrm{k}, \mathrm{CCA}} \\
(\mathrm{MPa})\end{array}$ & $\begin{array}{c}\mathbf{f}_{\mathrm{v} 0, \mathrm{k}, \mathrm{p}} \\
(\mathrm{MPa})\end{array}$ & $\begin{array}{l}\mathbf{f}_{\mathrm{v} 0, \mathrm{k}, \mathrm{CCA}} \\
(\mathrm{MPa})\end{array}$ \\
\hline 53,7 & 64,3 & 54,0 & 65,5 & 9,7 & 12,0 & 9,6 & 11,9 \\
\hline
\end{tabular}

TABELA 52 - Resistência característica à compressão e ao cisalhamento paralelo (amostra 02) - Eucalipto Grandis

\begin{tabular}{|c|c|c|c|c|c|c|c|c|c|c|c|}
\hline \multicolumn{6}{|c|}{ Resistência à compressão paralela } & \multicolumn{6}{|c|}{ Resistência ao cisalhamento paralelo } \\
\hline \multicolumn{3}{|c|}{ NBR 7190/97 } & \multicolumn{3}{|c|}{ LOGSDON (1998) } & \multicolumn{3}{|c|}{ NBR 7190/97 } & \multicolumn{3}{|c|}{ LOGSDON (1998) } \\
\hline $\begin{array}{c}\mathbf{f}_{\mathrm{c} 0 \mathrm{k}, \mathrm{p}} \\
(\mathrm{MPa})\end{array}$ & $\begin{array}{c}\mathbf{f}_{\mathrm{c} 0, \mathrm{k}, \mathrm{CC}} \\
\mathrm{A} \\
(\mathrm{MPa}) \\
\end{array}$ & $\begin{array}{c}f_{\mathrm{c} 0, \mathrm{k}, \mathrm{CCB}} \\
\text { (MPa) }\end{array}$ & $\begin{array}{l}\mathbf{f}_{\mathbf{c} 0, \mathrm{k}, \mathrm{p}} \\
\text { (MPa) }\end{array}$ & $\begin{array}{c}f_{\mathrm{c} 0, \mathrm{k}, \mathrm{CCA}} \\
\text { (MPa) }\end{array}$ & $\begin{array}{l}\mathbf{f}_{\mathrm{c} 0 \mathrm{k}, \mathrm{kCB}} \\
\text { (MPa) }\end{array}$ & $\begin{array}{l}\mathbf{f}_{\mathrm{v} 0, \mathbf{k}, \mathbf{p}} \\
(\mathrm{MPa})\end{array}$ & $\begin{array}{c}\mathbf{f}_{\mathrm{v} 0, \mathrm{k}, \mathrm{CCA}} \\
\text { (MPa) }\end{array}$ & \begin{tabular}{|c|}
$f_{\mathrm{v} 0, \mathrm{k}, \mathrm{CCB}}$ \\
(MPa)
\end{tabular} & $\begin{array}{l}\mathbf{f}_{\mathrm{v} 0, \mathrm{k}, \mathrm{p}} \\
(\mathrm{MPa})\end{array}$ & $\begin{array}{c}f_{\mathrm{v} 0, \mathrm{k}, \mathrm{CCA}} \\
\text { (MPa) }\end{array}$ & $\begin{array}{c}\mathbf{f}_{\mathrm{v} 0, \mathrm{k}, \mathrm{CCB}} \\
(\mathrm{MPa})\end{array}$ \\
\hline
\end{tabular}


\begin{tabular}{l|l|l|l|l|l|l|l|l|l|l|l}
64,1 & 63,8 & 71,0 & 66,2 & 65,7 & 73,1 & 11,7 & 11,1 & 10,7 & 11,4 & 11,0 & 10,4 \\
\hline
\end{tabular}

Os valores característicos das Tabelas 51 e 52 foram calculados a partir dos resultados de cada CP ensaiado (ver Tabelas 53, 54 e 55, respectivamente).

TABELA 53 - Valores individuais de resistência à compressão e ao cisalhamento paralelo (amostra 01) - Eucalipto Grandis

\begin{tabular}{c|c|c|c|c|c|c|c|c}
\hline \multirow{2}{*}{ CP } & \multicolumn{3}{|c|}{ Resistência à compressão paralela } & \multicolumn{2}{c}{ Resistência ao cisalhamento paralelo } \\
\cline { 2 - 9 } & $\begin{array}{c}\text { NBR 7190/97 } \\
\text { (MPa) }\end{array}$ & \multicolumn{2}{c|}{$\begin{array}{c}\text { LOGSDON (1998) } \\
\text { (MPa) }\end{array}$} & \multicolumn{2}{c|}{$\begin{array}{c}\text { NBR 7190/97 } \\
\text { (MPa) }\end{array}$} & \multicolumn{2}{c}{$\begin{array}{c}\text { LOGSDON (1998) } \\
\text { (MPa) }\end{array}$} \\
\cline { 2 - 8 } & Padrão & CCA & Padrão & CCA & Padrão & CCA & Padrão & CCA \\
\hline EGR-01 & 56,8 & 59,3 & 57,5 & 60,2 & 9,8 & 11,8 & 9,7 & 11,6 \\
EGR-02 & 61,2 & 60,0 & 61,7 & 61,0 & 10,8 & 12,0 & 10,7 & 11,8 \\
EGR-03 & 71,0 & 76,4 & 72,1 & 77,7 & 9,9 & 11,1 & 9,8 & 10,9 \\
EGR-04 & 51,3 & 60,8 & 51,6 & 61,6 & 11,2 & 11,4 & 11,2 & 11,2 \\
EGR-05 & 59,3 & 64,9 & 60,0 & 66,0 & 11,5 & 13,4 & 11,4 & 13,2 \\
EGR-06 & 73,1 & 75,0 & 74,3 & 76,2 & 11,5 & 11,6 & 11,4 & 11,4 \\
\hline
\end{tabular}

TABELA 54 - Valores individuais de resistência à compressão e ao cisalhamento paralelo (amostra 02) - Eucalipto Grandis (correção da umidade segundo NBR 7190/97)

\begin{tabular}{c|c|c|c|c|c|c}
\hline \multirow{2}{*}{ CP } & \multicolumn{3}{|c|}{$\begin{array}{c}\text { Resistência à compressão paralela } \\
\text { (Mpa) }\end{array}$} & \multicolumn{3}{c}{$\begin{array}{c}\text { Resistência ao cisalhamento paralelo } \\
\text { (Mpa) }\end{array}$} \\
\cline { 2 - 7 } & Padrão & CCA & CCB & Padrão & CCA & CCB \\
\hline EGR-07 & 63,6 & 60,7 & 68,6 & 17,0 & 13,3 & 13,2 \\
EGR-08 & 62,0 & 64,1 & 68,0 & 13,4 & 11,5 & 11,6 \\
EGR-09 & 66,2 & 59,4 & 66,7 & 11,7 & 11,9 & 11,0 \\
EGR-10 & 68,9 & 70,1 & 66,7 & 11,8 & 10,3 & 11,2 \\
EGR-11 & 65,3 & 69,3 & 68,1 & 14,2 & 15,3 & 13,1 \\
EGR-12 & 68,1 & 68,9 & 68,7 & 19,0 & 14,6 & 15,3 \\
EGR-13 & 66,1 & 67,3 & 63,8 & 13,2 & 12,6 & 11,1 \\
EGR-14 & 67,1 & 66,4 & 70,0 & 12,2 & 13,7 & 14,3 \\
EGR-15 & 65,8 & 72,1 & 72,3 & 13,5 & 14,4 & 14,1 \\
EGR-16 & 65,2 & 71,4 & 72,4 & 12,8 & 14,0 & 11,2 \\
EGR-17 & 59,8 & 64,6 & 68,4 & 13,8 & 15,2 & 15,0 \\
EGR-18 & 58,3 & 62,2 & 66,4 & 11,1 & 15,5 & 12,7 \\
\hline
\end{tabular}

TABELA 55 - Valores individuais de resistência à compressão e ao cisalhamento paralelo (amostra 02) - Eucalipto Grandis (correção da umidade segundo LOGSDON (1998))

\begin{tabular}{c|c|c|c|c|c|c}
\hline \multirow{2}{*}{ CP } & \multicolumn{3}{|c|}{ Resistência à compressão paralela } & \multicolumn{3}{c}{$\begin{array}{c}\text { Resistência ao cisalhamento paralelo } \\
\text { (Mpa) }\end{array}$} \\
\cline { 2 - 6 } & Padrão & CCA & CCB & Padrão & CCA & CCB \\
\hline EGR-07 & 65,7 & 62,7 & 70,3 & 16,5 & 13,2 & 12,8 \\
EGR-08 & 64,0 & 66,1 & 70,0 & 13,0 & 11,4 & 11,3 \\
EGR-09 & 68,4 & 60,9 & 68,4 & 11,4 & 11,8 & 10,7 \\
EGR-10 & 71,2 & 71,8 & 68,9 & 11,5 & 10,2 & 10,9 \\
EGR-11 & 67,4 & 71,4 & 69,9 & 13,7 & 15,1 & 12,7 \\
EGR-12 & 70,3 & 71,1 & 70,5 & 18,4 & 14,5 & 14,8 \\
EGR-13 & 68,3 & 69,5 & 65,8 & 12,8 & 12,5 & 10,7 \\
EGR-14 & 69,3 & 68,5 & 71,4 & 11,8 & 13,6 & 14,0 \\
EGR-15 & 68,0 & 74,4 & 74,4 & 13,0 & 14,3 & 13,7 \\
EGR-16 & 67,3 & 73,4 & 74,4 & 12,4 & 13,8 & 10,8 \\
EGR-17 & 61,8 & 66,7 & 70,4 & 13,4 & 15,0 & 14,5 \\
EGR-18 & 60,2 & 64,2 & 68,3 & 10,7 & 15,3 & 12,3 \\
\hline
\end{tabular}


Os dados contidos na Tabela 53 (referente a amostra 01) e nas Tabelas 54 e 55 (referente a amostra 02), serão expressos a partir da média aritmética e do coeficiente de variação (ver Tabelas 56, 57, 58 e 59).

TABELA 56 - Resistência à compressão paralela (amostra 01) - Eucalipto Grandis

\begin{tabular}{|c|c|c|c|c|c|c|c|}
\hline \multicolumn{8}{|c|}{ Método de correção da umidade } \\
\hline \multicolumn{4}{|c|}{ NBR 7190/97 } & \multicolumn{4}{|c|}{ LOGSDON (1998) } \\
\hline \multicolumn{2}{|c|}{ Padrão } & \multicolumn{2}{|c|}{ CCA } & \multicolumn{2}{|c|}{ Padrão } & \multicolumn{2}{|c|}{ CCA } \\
\hline $\mathrm{f}_{\mathrm{c} 0, \mathrm{~m}}(\mathrm{MPa})$ & CV (\%) & $\mathrm{f}_{\mathrm{c} 0, \mathrm{~m}}(\mathrm{MPa})$ & CV (\%) & $\mathrm{f}_{\mathrm{c} 0, \mathrm{~m}}(\mathrm{MPa})$ & CV (\%) & $\mathrm{f}_{\mathrm{c} 0, \mathrm{~m}}(\mathrm{MPa})$ & CV (\%) \\
\hline 62,1 & 13,5 & 66,1 & 11,7 & 62,9 & 13,9 & 67,1 & 11,8 \\
\hline
\end{tabular}

TABELA 57 - Resistência ao cisalhamento paralelo (amostra 01) - Eucalipto Grandis

\begin{tabular}{|c|c|c|c|c|c|c|c|}
\hline \multicolumn{8}{|c|}{ Método de correção da umidade } \\
\hline \multicolumn{4}{|c|}{ NBR 7190/97 } & \multicolumn{4}{|c|}{ LOGSDON (1998) } \\
\hline \multicolumn{2}{|c|}{ Padrão } & \multicolumn{2}{|c|}{ CCA } & \multicolumn{2}{|c|}{ Padrão } & \multicolumn{2}{|c|}{$\mathrm{CCA}$} \\
\hline $\mathrm{f}_{\mathrm{v} 0, \mathrm{~m}}(\mathrm{MPa})$ & CV (\%) & $\mathrm{f}_{\mathrm{v} 0, \mathrm{~m}}(\mathrm{MPa})$ & CV (\%) & $\mathrm{f}_{\mathrm{v} 0, \mathrm{~m}}(\mathrm{MPa})$ & CV (\%) & $\mathrm{f}_{\mathrm{v} 0, \mathrm{~m}}(\mathrm{MPa})$ & CV (\%) \\
\hline 10,8 & 7,1 & 11,9 & 6,9 & 10,7 & 7,2 & 11,7 & 6,8 \\
\hline
\end{tabular}

TABELA 58 - Resistência à compressão paralela (amostra 02) - Eucalipto Grandis

\begin{tabular}{|c|c|c|c|c|c|c|c|c|c|c|c|}
\hline \multicolumn{12}{|c|}{ Método de correção da umidade } \\
\hline \multicolumn{6}{|c|}{ NBR 7190/97 } & \multicolumn{6}{|c|}{ LOGSDON (1998) } \\
\hline \multicolumn{2}{|c|}{ Padrão } & \multicolumn{2}{|c|}{ CCA } & \multicolumn{2}{|c|}{ CCB } & \multicolumn{2}{|c|}{ Padrão } & \multicolumn{2}{|c|}{ CCA } & \multicolumn{2}{|c|}{ CCB } \\
\hline $\begin{array}{c}\mathbf{f}_{\mathbf{c o}, \mathrm{m}} \\
(\mathrm{MPa})\end{array}$ & $\begin{array}{l}\text { CV } \\
(\%)\end{array}$ & $\begin{array}{c}\mathbf{f}_{\mathrm{c} 0, \mathrm{~m}} \\
(\mathrm{MPa})\end{array}$ & $\begin{array}{l}\text { CV } \\
(\%)\end{array}$ & $\begin{array}{c}\mathbf{f}_{\mathrm{c} 0, \mathrm{~m}} \\
(\mathrm{MPa})\end{array}$ & $\begin{array}{l}\text { CV } \\
(\%)\end{array}$ & $\begin{array}{c}\mathbf{f}_{\mathbf{c 0}, \mathbf{m}} \\
(\mathbf{M P a})\end{array}$ & $\begin{array}{l}\text { CV } \\
(\%)\end{array}$ & $\begin{array}{c}\mathbf{f}_{\mathrm{c} 0, \mathrm{~m}} \\
(\mathrm{MPa})\end{array}$ & $\begin{array}{l}\text { CV } \\
(\%)\end{array}$ & $\begin{array}{c}\mathbf{f}_{\mathbf{c 0 , m}} \\
(\mathbf{M P a})\end{array}$ & $\begin{array}{l}\text { CV } \\
(\%)\end{array}$ \\
\hline 64,7 & 5,0 & 66,4 & 6,3 & 68,4 & 3,6 & 66,8 & 5,0 & 68,4 & 6,3 & 70,2 & 3,5 \\
\hline
\end{tabular}

TABELA 59 - Resistência ao cisalhamento paralelo (amostra 02) - Eucalipto Grandis

\begin{tabular}{|c|c|c|c|c|c|c|c|c|c|c|c|}
\hline \multicolumn{12}{|c|}{ Método de correção da umidade } \\
\hline \multicolumn{6}{|c|}{ NBR 7190/97 } & \multicolumn{6}{|c|}{ LOGSDON (1998) } \\
\hline \multicolumn{2}{|c|}{ Padrão } & \multicolumn{2}{|c|}{ CCA } & \multicolumn{2}{|c|}{ CCB } & \multicolumn{2}{|c|}{ Padrão } & \multicolumn{2}{|c|}{ CCA } & \multicolumn{2}{|c|}{ CCB } \\
\hline $\begin{array}{c}\mathbf{f}_{\mathrm{v} 0, \mathrm{~m}} \\
(\mathrm{MPa})\end{array}$ & $\begin{array}{l}\text { CV } \\
(\%)\end{array}$ & $\begin{array}{c}\mathbf{f}_{\mathrm{v} 0, \mathrm{~m}} \\
(\mathrm{MPa})\end{array}$ & $\begin{array}{l}\text { CV } \\
(\%)\end{array}$ & $\begin{array}{c}\mathbf{f}_{\mathrm{v} 0, \mathrm{~m}} \\
(\mathrm{MPa})\end{array}$ & $\begin{array}{l}\text { CV } \\
(\%)\end{array}$ & $\begin{array}{c}\mathbf{f}_{\mathrm{v} 0, \mathrm{~m}} \\
(\mathrm{MPa})\end{array}$ & $\begin{array}{l}\text { CV } \\
(\%)\end{array}$ & $\begin{array}{c}\mathbf{f}_{\mathbf{v 0}, \mathrm{m}} \\
(\mathbf{M P a})\end{array}$ & $\begin{array}{l}\text { CV } \\
(\%)\end{array}$ & $\begin{array}{c}\mathbf{f}_{\mathrm{v} 0, \mathrm{~m}} \\
(\mathrm{MPa})\end{array}$ & $\begin{array}{l}\text { CV } \\
(\%)\end{array}$ \\
\hline 13,6 & 16,7 & 13,5 & 12,3 & 12,8 & 12,5 & 13,2 & 16,7 & 13,4 & 12,1 & 12,4 & 12,5 \\
\hline
\end{tabular}

Conforme os resultados obtidos para a amostra 01, apresentados nas Tabelas 56 (compressão paralela) e 57 (cisalhamento paralelo), verificou-se que para ambas as formas de correção da umidade, a diferença dos valores dos coeficientes de variação entre os CP's naturais e preservados (CCA) foi de aproximadamente dois e meio ponto percentual, respectivamente. Desta forma, admite-se os resultados não foram influenciados de maneira relevante devido a anisotropia do material.

Para a amostra 02, Tabelas 58 (compressão paralela) e 59 (cisalhamento paralelo), verificou-se as seguintes diferença entre os valores dos coeficientes de variação dos CP's naturais e preservados: 
*Preservado com CCA - compressão (1,3 ponto percentual) e cisalhamento (4,5 ponto percentual);

*Preservado com CCB - compressão (1,5 ponto percentual) e cisalhamento $(4,2$ ponto percentual).

Com base nestes valores, também pode-se admitir que os resultados não foram influenciados de maneira relevante devido a anisotropia do material.

Assim como para as demais espécies já discutidas, o módulo de elasticidade longitudinal de cada CP foi obtido segundo as recomendações da NBR 7190/97 Anexo B (Item 8) e através de uma regressão linear simples. Os resultados da amostra 01 estão mostrados na Tabela 60, enquanto da amostra 02 encontram-se na Tabela 62. A Figura 21 mostra o módulo de elasticidade obtido através da regressão

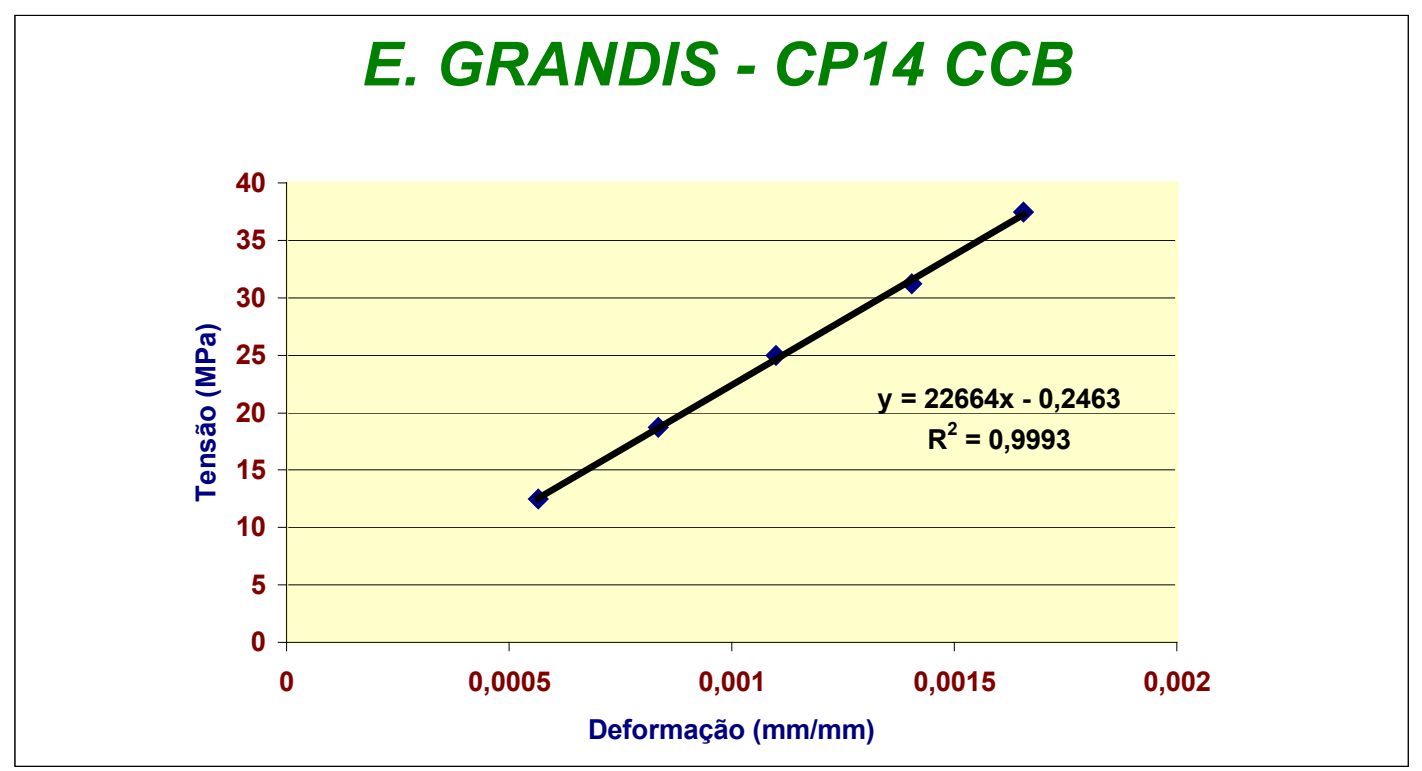

linear.

FIGURA 21 - Módulo de elasticidade longitudinal do Eucalipto Grandis (regressão linear simples)

TABELA 60 - Valores individuais de rigidez à compressão paralela (amostra 01) Eucalipto Grandis

\begin{tabular}{|c|c|c|c|c|c|c|}
\hline \multicolumn{7}{|c|}{ Correção da umidade - NBR 7190/97 } \\
\hline \multirow[b]{2}{*}{$\mathbf{C P}$} & \multicolumn{3}{|c|}{ Padrão } & \multicolumn{3}{|c|}{ CCA } \\
\hline & $\begin{array}{l}\mathbf{E}_{\mathrm{c0,NBR}} \\
(\mathrm{MPa})\end{array}$ & $\begin{array}{l}\mathbf{E}_{\mathrm{c} 0, \mathrm{Regr}} \\
\text { (MPa) }\end{array}$ & $\begin{array}{c}\Delta \\
(\%)\end{array}$ & $\begin{array}{l}\mathbf{E}_{\mathrm{c0}, \mathrm{NBR}} \\
(\mathrm{MPa})\end{array}$ & $\begin{array}{l}\mathbf{E}_{\mathrm{co,Regr}} \\
\text { (MPa) }\end{array}$ & $\begin{array}{c}\Delta \\
(\%)\end{array}$ \\
\hline EGR-01 & 15788 & 15767 & $-0,1$ & 15956 & 15656 & $-1,9$ \\
\hline EGR-02 & 16229 & 16160 & $-0,4$ & 16919 & 16234 & $-4,1$ \\
\hline EGR-03 & 21181 & 20175 & $-4,8$ & 21519 & 20753 & $-3,6$ \\
\hline EGR-04 & 15281 & 14938 & $-2,3$ & 16187 & 16155 & $-0,2$ \\
\hline EGR-05 & 15036 & 14491 & $-3,6$ & 16416 & 16418 & 0,0 \\
\hline
\end{tabular}




\begin{tabular}{c|c|c|c|c|c|c} 
EGR-06 & 20415 & 203529 & $-0,3$ & 21017 & 20676 & $-1,6$ \\
\hline \multicolumn{6}{c}{ Correção da umidade - LOGSDON (1998) } \\
Continuação... \\
\hline \multicolumn{6}{c}{ Padrão } & \multicolumn{3}{c}{ CCA } \\
\hline \multirow{2}{*}{ CP } & $\mathbf{E}_{\mathbf{c 0 , N B R}}$ & $\mathbf{E}_{\mathbf{c 0}, \mathbf{R e g r}}$ & $\Delta$ & $\mathbf{E}_{\mathbf{c 0}, \mathbf{N B R}}$ & $\mathbf{E}_{\mathbf{c} 0, \mathbf{R e g r}}$ & $\Delta$ \\
& $\mathbf{( M P a )}$ & $\mathbf{( M P a )}$ & $\mathbf{( \% )}$ & $\mathbf{( M P a )}$ & $\mathbf{( M P a )}$ & $\mathbf{( \% )}$ \\
\hline EGR-01 & 15990 & 15969 & $-0,1$ & 16196 & 15891 & $-1,9$ \\
EGR-02 & 16378 & 16308 & $-0,4$ & 17210 & 16513 & $-4,1$ \\
EGR-03 & 21499 & 20478 & $-4,8$ & 21900 & 21119 & $-3,6$ \\
EGR-04 & 15371 & 15026 & $-2,3$ & 16402 & 16369 & $-0,2$ \\
EGR-05 & 15222 & 14670 & $-3,6$ & 16713 & 16715 & 0,0 \\
EGR-06 & 20757 & 20694 & $-0,3$ & 21370 & 21023 & $-1,6$ \\
\hline
\end{tabular}

Neste caso, a semelhança dos valores dos módulos de elasticidade longitudinal " $\mathrm{E}_{\mathrm{c} 0, \mathrm{NBR}}$ " e " $\mathrm{E}_{\mathrm{c} 0 \text {,Regr }}$ " determinados para os CP's preservados e naturais da amostra 01, também levou à utilização do Teste de Dados Pareados (Pairing) para mostrar a possível equivalência estatística dos mesmos.

Para o conjunto de dados dos CP's não preservados e umidade corrigida segundo as recomendações da NBR 7190/97, obteve-se o seguinte intervalo de confiança: $-61,7 \leq \mu_{x} \leq 744,1$. Pode-se verificar que tal intervalo contém o valor zero e, consequentemente, os citados conjuntos podem ser considerados estatisticamente equivalentes. Para os CP's preservados com CCA, o intervalo de confiança obtido foi igual a $18,2 \leq \mu_{x} \leq 689,8$. Portanto, tais conjuntos não podem ser considerados estatisticamente equivalentes.

Para os conjuntos submetidos à correção da umidade proposta por LOGSDON (1998), verificou-se os seguintes resultados: CP preservados $\left(18,1 \leq \mu_{x} \leq 702,2\right)$; CP não preservados $\left(-63,3 \leq \mu_{x} \leq 754,4\right)$. Neste caso, assim como no anterior, pode-se chegar na mesma conclusão.

$\mathrm{Na}$ espécie em questão, assim como nas anteriores, expressou-se o módulo de elasticidade longitudinal através da média aritmética e do coeficiente de variação.

TABELA 61 - Parâmetros estatísticos para a rigidez à compressão paralela (amostra 01) - Eucalipto Grandis

\begin{tabular}{c|c|c|c|c|c|c|c}
\hline \multicolumn{7}{c}{ Método de correção da umidade } \\
\hline \multicolumn{3}{c|}{ NBR 7190/97 } & \multicolumn{3}{c}{ LOGSDON (1998) } \\
\hline \multicolumn{2}{c|}{ Padrão } & \multicolumn{3}{c|}{ CCA } & \multicolumn{2}{c}{ Padrão } & \multicolumn{3}{c}{ CCA } \\
\hline $\mathbf{E}_{\mathbf{c} 0, \mathrm{~m}}(\mathbf{M P a})$ & $\mathbf{C V}(\%)$ & $\mathbf{E}_{\mathrm{c} 0, \mathrm{~m}}(\mathbf{M P a})$ & $\mathbf{C V}(\%)$ & $\mathbf{E}_{\mathbf{c} 0, \mathrm{~m}}(\mathbf{M P a})$ & $\mathbf{C V}(\%)$ & $\mathbf{E}_{\mathbf{c} 0, \mathrm{~m}}(\mathbf{M P a})$ & $\mathbf{C V}(\%)$ \\
\hline 16980 & 15,4 & 17648 & 13,5 & 17191 & 15,7 & 17938 & 13,6 \\
\hline
\end{tabular}


A Tabela 61 mostra que nas duas maneiras de correção da umidade, a diferença entre os valores dos coeficientes de variação dos CP's preservados e sem preservação foi inferior a dois porcento. Com base nestes valores, é possível aceitar que a anisotropia do material não influenciou de forma relevante nos resultados apresentados na Tabela 60.

TABELA 62 - Valores individuais de rigidez à compressão paralela (amostra 02) Eucalipto Grandis

\begin{tabular}{|c|c|c|c|c|c|c|c|c|c|}
\hline \multirow[b]{3}{*}{$\mathbf{C P}$} & \multicolumn{9}{|c|}{ Correção da umidade - NBR 7190/97 } \\
\hline & \multicolumn{3}{|c|}{ Padrão } & \multicolumn{3}{|c|}{ CCA } & \multicolumn{3}{|c|}{ CCB } \\
\hline & $\begin{array}{l}\mathbf{E}_{\mathrm{c} 0, \mathrm{NBR}} \\
(\mathrm{MPa})\end{array}$ & $\begin{array}{l}\mathbf{E}_{\text {c0,Regr }} \\
(\mathrm{MPa})\end{array}$ & $\begin{array}{c}\Delta \\
(\%)\end{array}$ & $\begin{array}{l}\mathbf{E}_{\mathrm{c} 0, \mathrm{NBR}} \\
(\mathrm{MPa})\end{array}$ & $\begin{array}{l}\mathbf{E}_{\mathrm{c} 0, \mathrm{Regr}} \\
(\mathrm{MPa})\end{array}$ & $\begin{array}{c}\Delta \\
(\%)\end{array}$ & $\begin{array}{l}\mathbf{E}_{\mathrm{c} 0, \mathrm{NBR}} \\
(\mathrm{MPa})\end{array}$ & $\begin{array}{l}\mathbf{E}_{\mathrm{c} 0, \mathrm{Regr}} \\
(\mathrm{MPa})\end{array}$ & $\begin{array}{c}\Delta \\
(\%)\end{array}$ \\
\hline EGR-07 & 33109 & 30209 & $-8,8$ & 27096 & 26356 & $-2,7$ & 25540 & 25489 & $-0,2$ \\
\hline EGR-08 & 26953 & 25508 & $-5,4$ & 28607 & 28729 & 0,4 & 26769 & 25928 & $-3,1$ \\
\hline EGR-09 & 25658 & 23889 & $-6,9$ & 22875 & 22041 & $-3,7$ & 21583 & 21275 & $-1,4$ \\
\hline EGR-10 & 23904 & 23555 & $-1,5$ & 23628 & 23617 & $-0,0$ & 23737 & 22227 & $-6,4$ \\
\hline EGR-11 & 24806 & 24876 & 0,3 & 24344 & 24243 & $-0,4$ & 25646 & 25547 & $-0,4$ \\
\hline EGR-12 & 24680 & 24780 & 0,4 & 24847 & 23677 & $-4,7$ & 23936 & 23216 & $-3,0$ \\
\hline EGR-13 & 32825 & 33335 & 1,6 & 29458 & 29326 & $-0,5$ & 28510 & 26105 & $-8,4$ \\
\hline EGR-14 & 23241 & 24241 & 4,3 & 24651 & 24629 & $-0,1$ & 29323 & 27277 & $-7,0$ \\
\hline EGR-15 & 29466 & 29452 & $-0,1$ & 30617 & 28856 & $-5,8$ & 28579 & 27273 & $-4,6$ \\
\hline EGR-16 & 26126 & 26283 & 0,6 & 29219 & 27671 & $-5,3$ & 25496 & 25257 & $-0,9$ \\
\hline EGR-17 & 23812 & 23824 & 0,1 & 26582 & 26535 & $-0,2$ & 25704 & 25709 & 0,0 \\
\hline EGR-18 & 23918 & 23903 & $-0,1$ & 25100 & 25457 & 1,4 & 26091 & 26031 & $-0,2$ \\
\hline \multicolumn{10}{|c|}{ Correção da umidade - LOGSDON (1998) } \\
\hline EGR-07 & 34251 & 31250 & $-8,8$ & 28031 & 27265 & $-2,7$ & 26213 & 26162 & $-0,2$ \\
\hline EGR-08 & 27882 & 26388 & $-5,4$ & 29592 & 29719 & 0,4 & 27611 & 26744 & $-3,1$ \\
\hline EGR-09 & 26542 & 24713 & $-6,9$ & 23506 & 22648 & $-3,7$ & 22144 & 21828 & $-1,4$ \\
\hline EGR-10 & 24728 & 24367 & $-1,5$ & 24260 & 24250 & $-0,0$ & 24555 & 22993 & $-6,4$ \\
\hline EGR-11 & 25661 & 25734 & 0,3 & 24009 & 23911 & $-0,4$ & 26363 & 26261 & $-0,4$ \\
\hline EGR-12 & 25531 & 25634 & 0,4 & 25704 & 24493 & $-4,7$ & 24596 & 23857 & $-3,0$ \\
\hline EGR-13 & 33336 & 34484 & 1,6 & 30474 & 30337 & $-0,5$ & 29493 & 27005 & $-8,4$ \\
\hline EGR-14 & 24043 & 25076 & 4,3 & 25501 & 25478 & $-0,1$ & 29977 & 27885 & $-7,0$ \\
\hline EGR-15 & 30482 & 30468 & $-0,1$ & 31650 & 29820 & $-5,8$ & 29456 & 28111 & $-4,6$ \\
\hline EGR-16 & 27027 & 27190 & 0,6 & 30082 & 28488 & $-5,3$ & 26239 & 25994 & $-0,9$ \\
\hline EGR-17 & 24634 & 24646 & 0,1 & 27499 & 27450 & $-0,2$ & 26483 & 26488 & 0,0 \\
\hline EGR-18 & 24743 & 24727 & $-0,1$ & 25966 & 26335 & 1,4 & 26892 & 26830 & $-0,2$ \\
\hline
\end{tabular}

Pelo mesmo motivo discutido anteriormente, a amostra 02 também foi submetida à análise do Teste de Dados Pareados (Pairing). Nesta amostra, através das recomendações prescritas na NBR 7190/97 para a correção da umidade, determinou-se os intervalos de confiança mostrado abaixo: CP's não preservados $\left(-310,5 \leq \mu_{x} \leq 1084,2\right)$; CP's preservados com CCA $\left(45,7 \leq \mu_{x} \leq 935,3\right)$; CP's preservados com CCB $\left(266,5 \leq \mu_{x} \leq 1330,0\right)$.

De acordo com o exposto, verificou-se que os conjuntos de dados referentes

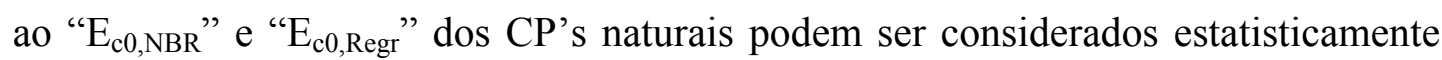
equivalentes. $\mathrm{O}$ mesmo não pode ser afirmado para os CP's preservados com CCA e 
CCB. Para os conjuntos de dados submetidos à correção da umidade proposta por LOGSDON (1998), chegaram-se às mesmas conclusões.

Da mesma maneira que a amostra 01, o módulo de elasticidade longitudinal foi apresentado em função da média aritmética e do coeficiente de variação (ver Tabela 63).

TABELA 63 - Parâmetros estatísticos para a rigidez à compressão paralela (amostra 02) - Eucalipto Grandis

\begin{tabular}{|c|c|c|c|c|c|c|c|c|c|c|c|}
\hline \multicolumn{12}{|c|}{ Método de correção da umidade } \\
\hline \multicolumn{6}{|c|}{ NBR 7190/97 } & \multicolumn{6}{|c|}{ LOGSDON (1998) } \\
\hline \multicolumn{2}{|c|}{ Padrão } & \multicolumn{2}{|c|}{ CCA } & \multicolumn{2}{|c|}{ CCB } & \multicolumn{2}{|c|}{ Padrão } & \multicolumn{2}{|c|}{ CCA } & \multicolumn{2}{|c|}{ CCB } \\
\hline $\begin{array}{c}\mathbf{E}_{\mathrm{c} 0, \mathrm{~m}} \\
(\mathrm{MPa})\end{array}$ & $\begin{array}{l}\text { CV } \\
(\%)\end{array}$ & $\begin{array}{c}\mathbf{E}_{\mathrm{c} 0, \mathrm{~m}} \\
(\mathrm{MPa})\end{array}$ & $\begin{array}{l}\text { CV } \\
(\%)\end{array}$ & $\begin{array}{c}\mathrm{E}_{\mathrm{c} 0, \mathrm{~m}} \\
(\mathrm{MPa})\end{array}$ & $\begin{array}{l}\text { CV } \\
(\%)\end{array}$ & $\begin{array}{c}\mathbf{E}_{\mathrm{c} 0, \mathrm{~m}} \\
(\mathrm{MPa})\end{array}$ & $\begin{array}{l}\text { CV } \\
(\%)\end{array}$ & $\begin{array}{c}\mathbf{E}_{\mathrm{c} 0, \mathrm{~m}} \\
(\mathrm{MPa})\end{array}$ & $\begin{array}{l}\text { CV } \\
(\%)\end{array}$ & $\begin{array}{c}\mathbf{E}_{\mathrm{c} 0, \mathrm{~m}} \\
(\mathrm{MPa})\end{array}$ & $\begin{array}{l}\text { CV } \\
(\%)\end{array}$ \\
\hline 26155 & 12,0 & 25928 & 9,2 & 25111 & 7,5 & 27057 & 12,0 & 26684 & 9,7 & 25846 & 7,5 \\
\hline
\end{tabular}

A Tabela 63 apresentou uma redução dos valores dos coeficientes de variação dos CP's preservados em relação ao natural. Para os CP's impregnados com CCB, a redução atingiu aproximadamente quatro e meio pontos percentuais, enquanto os CP's com CCA obtiveram um decréscimo em torno de dois e meio pontos percentuais.

Dos resultados apresentados nas Tabelas 53 e 60, obteve-se a Tabela 64, cujos valores representam os quocientes das propriedades de resistência e de rigidez entre os CP's preservados e naturais da amostra 01.

TABELA 64 - Relação da resistência e da rigidez entre os CP's preservado (CCA) e os naturais (sem preservação) (amostra 01) - Eucalipto Grandis

\begin{tabular}{|c|c|c|c|c|c|c|}
\hline \multirow{2}{*}{$\mathbf{C P}$} & \multicolumn{3}{|c|}{ NBR 7190/97 } & \multicolumn{3}{|c|}{ LOGSDON (1998) } \\
\hline & $\left(\mathbf{f}_{\mathrm{c} 0, \mathrm{CCA}} / \mathbf{f}_{\mathrm{c} 0, \mathrm{p}}\right)$ & $\left(\mathbf{f}_{\mathrm{v} 0, \mathrm{CCA}} / \mathbf{f}_{\mathrm{v} 0, \mathrm{p}}\right)$ & $\left(\mathbf{E}_{\mathrm{c} 0, \mathrm{CCA}} / \mathbf{E}_{\mathrm{c} 0, \mathrm{p}}\right)_{\mathrm{Regr}}$ & $\left(\mathbf{f}_{\mathrm{c} 0, \mathrm{CCA}} / \mathbf{f}_{\mathrm{c} 0, \mathrm{p}}\right)$ & $\left(\mathbf{f}_{\mathrm{v} 0, \mathrm{CCA}} / \mathbf{f}_{\mathrm{v} 0, \mathrm{p}}\right)$ & $\left(\mathbf{E}_{\mathrm{c} 0, \mathrm{CCA}} / \mathbf{E}_{\mathrm{c} 0, \mathrm{p}}\right)_{\mathrm{Regr}}$ \\
\hline EGR-01 & 1,04 & 1,20 & 0,99 & 1,05 & 1,19 & 1,00 \\
\hline EGR-02 & 0,98 & 1,11 & 1,00 & 0,99 & 1,10 & 1,01 \\
\hline EGR-03 & 1,08 & 1,12 & 1,03 & 1,08 & 1,12 & 1,03 \\
\hline EGR-04 & 1,18 & 1,02 & 1,08 & 1,19 & 1,01 & 1,09 \\
\hline EGR-05 & 1,09 & 1,17 & 1,13 & 1,10 & 1,16 & 1,14 \\
\hline EGR-06 & 1,03 & 1,00 & 1,02 & 1,03 & 1,00 & 1,02 \\
\hline
\end{tabular}

De modo preliminar, a validade dos resultados da Tabela 64 pode ser comprovada através dos dados estatísticos apresentados na Tabela 65. 
TABELA 65 - Parâmetros estatísticos da relação da resistência e da rigidez entre os CP's preservado (CCA) e os naturais (sem preservação) (amostra 01) Eucalipto Grandis

\begin{tabular}{|c|c|c|c|c|c|c|c|c|c|c|c|}
\hline \multicolumn{6}{|c|}{ NBR 7190/97 } & \multicolumn{6}{|c|}{ LOGSDON (1998) } \\
\hline \multicolumn{2}{|c|}{$\left(\mathbf{f}_{\mathrm{c} 0, \mathrm{CCA}} / \mathbf{f}_{\mathrm{c} 0, \mathrm{p}}\right)$} & \multicolumn{2}{|c|}{$\left(\mathbf{f}_{\mathrm{v} 0, \mathrm{CCA}} / \mathbf{f}_{\mathrm{v} 0, \mathrm{p}}\right)$} & \multicolumn{2}{|c|}{$\left(\mathbf{E}_{\mathrm{cc} 0, \mathrm{CCA}} / \mathbf{E}_{\mathrm{c} 0, \mathrm{p}}\right)_{\mathrm{Regr}}$} & \multicolumn{2}{|c|}{$\left(\mathbf{f}_{\mathrm{c} 0, \mathrm{CCA}} / \mathbf{f}_{\mathrm{c} 0, \mathrm{p}}\right)$} & \multicolumn{2}{|c|}{$\left(\mathbf{f}_{\mathrm{v} 0, \mathrm{CCA}} / \mathbf{f}_{\mathrm{v} 0, \mathrm{p}}\right)$} & \multicolumn{2}{|c|}{$\left(\mathbf{E}_{\mathrm{c} 0, \mathrm{CCA}} / \mathbf{E}_{\mathrm{c} 0, \mathrm{p}}\right)_{\mathrm{Regr}}$} \\
\hline Média & $\begin{array}{l}\text { CV } \\
(\%)\end{array}$ & Média & $\begin{array}{l}\text { CV } \\
\text { (\%) }\end{array}$ & Média & $\begin{array}{l}\text { CV } \\
(\%)\end{array}$ & Média & $\begin{array}{l}\text { CV } \\
(\%)\end{array}$ & Média & $\begin{array}{l}\text { CV } \\
\text { (\%) }\end{array}$ & Média & $\begin{array}{l}\text { CV } \\
\text { (\%) }\end{array}$ \\
\hline 1,07 & 6,5 & 1,10 & 7,2 & 1,04 & 5,1 & 1,07 & 6,5 & 1,10 & 7,2 & 1,0 & 5,3 \\
\hline
\end{tabular}

Da tabela acima, constatou-se que, em ambas as formas de correção de umidade, as médias das relações das resistências e da rigidez se mantiveram praticamente inalteradas. Além disto, os valores dos coeficientes de variação foram relativamente baixos, o que significa pouca dispersão em relação aos valores médios.

Sobre a amostra 01 , na compressão paralela às fibras e baseado na correção da umidade recomendada pela NBR 7190/97, verificou-se um aumento médio de sete por cento da resistência dos CP's preservados em relação aos naturais, para um coeficiente de variação em torno de seis e meio por cento. Para a rigidez, o acréscimo foi de quatro por cento, e um coeficiente de variação em torno de cinco por cento. De acordo com a correção proposta por LOGSDON (1998), tanto a resistência quanto a rigidez se equivalem aos valores anteriores.

Analisando os resultados do cisalhamento paralelo, notou-se um acréscimo de 10\% para a resistência dos CP's preservados, independente da maneira de correção da umidade. O coeficiente de variação em ambos os casos ficou em torno de sete pontos percentuais.

Por motivos já discutidos, a confiabilidade dos valores apresentados na Tabela 65 também será verificada através do Teste de Dados Pareados.

Da Tabela 53, verificou-se que os conjuntos de dados referentes aos CP's tratados com CCA e naturais submetidos à compressão paralela, com correção da umidade recomendada pela NBR 7190/97 e sugerida por LOGSDON (1998), apresentaram os seguintes intervalos de confiança da média, respectivamente: $\left(-7,8 \leq \mu_{x} \leq-0,1\right)$ e $\left(-8,2 \leq \mu_{x} \leq-0,3\right)$. A partir daí, concluí-se que tais conjuntos de dados não podem ser considerados estatisticamente equivalentes. Desta maneira, em ambos os casos é conveniente adotar um fator que considere a influência do produto preservativo e do processo de tratamento nas propriedades de resistência à 
compressão paralela às fibras. Este fator poderá ser igual aos valores médios explicitados na Tabela 65, ou seja 1,07.

Conforme os dados da Tabela 60 , obtiveram-se os intervalo de confiança iguais a $\left(-1476,7 \leq \mu_{x} \leq 140,8\right)$ e $\left(-1586,7 \leq \mu_{x} \leq 91,3\right)$, referente às correções da umidade pela NBR 7190/97 e por LOGSDON (1998), respectivamente. Portanto, deve-se considerar a equivalência dos dados dos conjuntos. Em virtude disto, é conveniente adotar para o módulo de elasticidade longitudinal um fator igual a 1,0.

Para as formas de correção da umidade aqui mencionadas, foi constatado que os conjuntos de dados referentes aos CP's tratados e naturais submetidos aos ensaios de cisalhamento paralelo (ver Tabela 53) não são estatisticamente equivalentes. Esta conclusão ocorreu com base nos resultados a seguir: NBR 7190/97 $\left(-2,0 \leq \mu_{x} \leq-0,20\right)$ e LOGSDON (1998): $\left(-1,9 \leq \mu_{x} \leq-0,2\right)$. Assim sendo, admite-se que o produto químico e o processo de preservação irão influenciar de maneira significativa sobre a resistência ao cisalhamento paralelo às fibras. Por isso, o fator sugerido para quantificar tal efeito deve ser igual ao valor médio, ou seja, 1,10 .

Resumidamente, a Tabela 66 apresenta os valores propostos a serem adotados como fatores que levem em consideração o efeito do produto e do processo preservativo nas propriedades mecânicas da madeira.

TABELA 66 - Fator K - efeito do preservativo (CCA)e do processo de tratamento nas propriedades mecânicas (amostra 01) - Eucalipto Grandis

\begin{tabular}{|c|c|c|c|c|c|}
\hline \multicolumn{3}{|c|}{ NBR 7190/97 } & \multicolumn{3}{|c|}{ LOGSDON (1998) } \\
\hline$\left(\mathbf{f}_{\mathrm{c} 0, \mathrm{CCA}} / \mathbf{f}_{\mathrm{c} 0, \mathrm{p}}\right)$ & $\left(\mathbf{f}_{\mathrm{v} 0, \mathrm{CCA}} / \mathbf{f}_{\mathrm{v} 0, \mathrm{p}}\right)$ & $\left(\mathbf{E}_{\mathrm{c} 0, \mathrm{CCA}} / \mathbf{E}_{\mathrm{c} 0, \mathrm{p}}\right)_{\mathrm{Regr}}$ & $\left(\mathbf{f}_{\mathrm{c} 0, \mathrm{CCA}} / \mathbf{f}_{\mathrm{c} 0, \mathrm{p}}\right)$ & $\left(\mathbf{f}_{\mathrm{v} 0, \mathrm{CCA}} / \mathbf{f}_{\mathrm{v} 0, \mathrm{p}}\right)$ & $\left(\mathbf{E}_{\mathrm{c} 0, \mathrm{CCA}} / \mathbf{E}_{\mathrm{c} 0, \mathrm{p}}\right)_{\mathrm{Regr}}$ \\
\hline 1,07 & 1,10 & 1,0 & 1,07 & 1,10 & 1,0 \\
\hline
\end{tabular}

A partir das Tabelas 54, 55 e 62, determinou-se os quocientes das propriedades mecânicas já mencionadas, porém para a amostra 02 . Tais valores estão expostos na Tabela 67.

TABELA 67 - Relação da resistência e da rigidez entre os CP's preservado (CCA e CCB) e os naturais (sem preservação) (amostra 02) - Eucalipto Grandis

\begin{tabular}{|c|c|c|c|c|c|c|}
\hline \multicolumn{7}{|c|}{ NBR 7190/97 } \\
\hline $\mathrm{CP}$ & $\left(\mathbf{f}_{\mathrm{c} 0, \mathrm{CCA}} / \mathbf{f}_{\mathrm{c} 0, \mathrm{p}}\right)$ & $\left(\mathbf{f}_{\mathrm{v} 0, \mathrm{CCA}} / \mathbf{f}_{\mathrm{v} 0, \mathrm{p}}\right)$ & $\left(\mathrm{E}_{\mathrm{c} 0, \mathrm{CCA}} / \mathrm{E}_{\mathrm{c} 0, \mathrm{p}}\right)_{\mathrm{Regr}}$ & $\left(\mathrm{f}_{\mathrm{c} 0, \mathrm{CCB}} / \mathrm{f}_{\mathrm{c} 0, \mathrm{p}}\right)$ & $\left(\mathbf{f}_{\mathrm{v} 0, \mathrm{CCB}} / \mathbf{f}_{\mathrm{v} 0, \mathrm{p}}\right)$ & $\left(\mathbf{E}_{\mathrm{c} 0, \mathrm{CCB}} / \mathbf{E}_{\mathrm{c} 0, \mathrm{p}}\right)_{\mathrm{Regr}}$ \\
\hline EGR-07 & 0,95 & 0,78 & 0,87 & 1,08 & 0,78 & 0,78 \\
\hline EGR-08 & 1,03 & 0,85 & 1,13 & 1,10 & 0,87 & 1,02 \\
\hline EGR-09 & 0,90 & 1,01 & 0,92 & 1,00 & 0,94 & 0,89 \\
\hline EGR-10 & 1,02 & 0,87 & 1,00 & 0,97 & 0,95 & 0,94 \\
\hline
\end{tabular}




\begin{tabular}{|c|c|c|c|c|c|c|}
\hline EGR-11 & 1,06 & 1,08 & 0,97 & 1,04 & 0,92 & 1,03 \\
\hline \multicolumn{7}{|c|}{ Continuação... } \\
\hline \multicolumn{7}{|c|}{ NBR 7190/97 } \\
\hline $\mathbf{C P}$ & $\left(\mathbf{f}_{\mathrm{c} 0, \mathrm{CCA}} / \mathbf{f}_{\mathrm{c} 0, \mathrm{p}}\right)$ & $\left(\mathbf{f}_{\mathrm{v} 0, \mathrm{CCA}} / \mathbf{f}_{\mathrm{v} 0, \mathrm{p}}\right)$ & $\left(E_{c 0, C C A} / E_{c 0, p}\right)_{\text {Regr }}$ & $\left(\mathbf{f}_{\mathrm{c} 0, \mathrm{CCB}} / \mathbf{f}_{\mathrm{c} 0, \mathrm{p}}\right)$ & $\left(\mathbf{f}_{\mathrm{v} 0, \mathrm{CCB}} / \mathbf{f}_{\mathrm{v} 0, \mathrm{p}}\right)$ & $\left(\mathbf{E}_{\mathrm{c} 0, \mathrm{CCB}} / \mathbf{E}_{\mathrm{c} 0, \mathrm{p}}\right)_{\mathrm{Regr}}$ \\
\hline EGR-12 & 1,01 & 0,77 & 0,96 & 1,01 & 0,81 & 0,94 \\
\hline EGR-13 & 1,02 & 0,96 & 0,88 & 0,96 & 0,84 & 0,78 \\
\hline EGR-14 & 0,99 & 1,13 & 1,02 & 1,04 & 1,18 & 1,13 \\
\hline EGR-15 & 1,09 & 1,07 & 0,98 & 1,10 & 1,05 & 0,93 \\
\hline EGR-16 & 1,09 & 1,09 & 1,05 & 1,11 & 0,87 & 0,96 \\
\hline EGR-17 & 1,08 & 1,10 & 1,11 & 1,14 & 1,09 & 1,08 \\
\hline EGR-18 & 1,07 & 1,40 & 1,07 & 1,14 & 1,15 & 1,09 \\
\hline \multicolumn{7}{|c|}{ LOGSDON (1998) } \\
\hline $\mathbf{C P}$ & $\left(\mathbf{f}_{\mathrm{c} 0, \mathrm{CCA}} / \mathbf{f}_{\mathrm{c} 0, \mathrm{p}}\right)$ & $\left(\mathbf{f}_{\mathrm{v} 0, \mathrm{CCA}} / \mathbf{f}_{\mathrm{v} 0, \mathrm{p}}\right)$ & $\left(\mathbf{E}_{\mathrm{c} 0, \mathrm{CCA}} / \mathbf{E}_{\mathrm{c} 0, \mathrm{p}}\right)_{\mathrm{Regr}}$ & $\left(\mathbf{f}_{\mathrm{c} 0, \mathrm{CCB}} / \mathbf{f}_{\mathrm{c} 0, \mathrm{p}}\right)$ & $\left(\mathbf{f}_{\mathrm{v} 0, \mathrm{CCB}} / \mathbf{f}_{\mathrm{v} 0, \mathrm{p}}\right)$ & $\left(\mathbf{E}_{\mathrm{c} 0, \mathrm{CCB}} / \mathbf{E}_{\mathrm{c} 0, \mathrm{p}}\right)_{\mathrm{Regr}}$ \\
\hline EGR-07 & 0,95 & 0,80 & 0,87 & 1,07 & 0,78 & 0,84 \\
\hline EGR-08 & 1,03 & 0,88 & 1,13 & 1,09 & 0,87 & 1,01 \\
\hline EGR-09 & 0,89 & 1,04 & 0,92 & 1,00 & 0,94 & 0,88 \\
\hline EGR-10 & 1,01 & 0,89 & 1,00 & 0,97 & 0,95 & 0,94 \\
\hline EGR-11 & 1,06 & 1,10 & 0,93 & 1,04 & 0,92 & 1,02 \\
\hline EGR-12 & 1,01 & 0,79 & 0,96 & 1,00 & 0,81 & 0,93 \\
\hline EGR-13 & 1,02 & 0,98 & 0,88 & 0,96 & 0,84 & 0,78 \\
\hline EGR-14 & 0,99 & 1,16 & 1,02 & 1,03 & 1,19 & 1,11 \\
\hline EGR-15 & 1,09 & 1,10 & 0,98 & 1,09 & 1,05 & 0,92 \\
\hline EGR-16 & 1,09 & 1,12 & 1,05 & 1,11 & 0,87 & 0,96 \\
\hline EGR-17 & 1,08 & 1,12 & 1,11 & 1,14 & 1,09 & 1,07 \\
\hline EGR-18 & 1,07 & 1,43 & 1,07 & 1,13 & 1,15 & 1,09 \\
\hline
\end{tabular}

Os resultados da tabela anterior são apresentados nas Tabelas 68 e 69 através de uma abordagem estatística.

TABELA 68 - Parâmetros estatísticos da relação da resistência e da rigidez entre os CP's preservado (CCA) e os naturais (sem preservação) (amostra 02) Eucalipto Grandis

\begin{tabular}{|c|c|c|c|c|c|c|c|c|c|c|c|}
\hline \multicolumn{6}{|c|}{ NBR 7190/97 } & \multicolumn{6}{|c|}{ LOGSDON (1998) } \\
\hline \multicolumn{2}{|c|}{$\left(\mathbf{f}_{\mathrm{c} 0, \mathrm{CCA}} / \mathbf{f}_{\mathrm{c} 0, \mathrm{p}}\right)$} & \multicolumn{2}{|c|}{$\left(\mathbf{f}_{\mathrm{v} 0, \mathrm{CCA}} / \mathbf{f}_{\mathrm{v} 0, \mathrm{p}}\right)$} & \multicolumn{2}{|c|}{$\left(\mathbf{E}_{\mathrm{c} 0, \mathrm{CCA}} / \mathbf{E}_{\mathrm{c} 0, \mathrm{p}}\right)_{\mathrm{Regr}}$} & \multicolumn{2}{|c|}{$\left(\mathbf{f}_{\mathrm{c} 0, \mathrm{CCA}} / \mathbf{f}_{\mathrm{c} 0, \mathrm{p}}\right)$} & \multicolumn{2}{|c|}{$\left(\mathbf{f}_{\mathrm{v} 0, \mathrm{CCA}} / \mathbf{f}_{\mathrm{v} 0, \mathrm{p}}\right)$} & \multicolumn{2}{|c|}{$\left(\mathrm{E}_{\mathrm{c} 0, \mathrm{CCA}} / \mathrm{E}_{\mathrm{c} 0, \mathrm{p}}\right)_{\mathrm{Regr}}$} \\
\hline Média & CV (\%) & Média & CV (\%) & Média & CV (\%) & Média & CV (\%) & Média & CV (\%) & Média & CV (\%) \\
\hline 1,03 & 5,7 & 1,01 & 17,6 & 1,00 & 8,4 & 1,03 & 5,9 & 1,03 & 17,5 & 0,99 & 8,6 \\
\hline
\end{tabular}

De acordo com a tabela acima, constatou-se que as médias das relações das resistências e da rigidez pouco se alteraram, considerando as correção de umidade propostas pela NBR 7190/97 e por LOGSDON (1998). O mesmo pode ser dito sobre os valores dos coeficientes de variação referentes à compressão, ao cisalhamento e à rigidez paralela às fibras. A amostra 02 na compressão paralela às fibras apresentou um aumento médio de três por cento da resistência dos CP's preservados com CCA em relação aos naturais, tomando como base as citadas correções da umidade. Verificou-se também um coeficiente de variação inferior a seis por cento. Para a rigidez, praticamente não houve alteração no que se refere à resistência, porém, o coeficiente de variação alcançou oito pontos percentuais. Analisando os resultados 
do cisalhamento paralelo, notou-se um acréscimo da resistência dos CP's preservados na ordem de um a três por cento. O coeficiente de variação em ambos os casos atingiu o patamar de 17\%. Este valor foi aceito como razoável, uma vez que, o coeficiente de variação para solicitação tangencial preconizada por norma (NBR $7190 / 97)$ é de $28 \%$.

TABELA 69 - Parâmetros estatísticos da relação da resistência e da rigidez entre os CP's preservado (CCB) e os naturais (sem preservação) (amostra 02) Eucalipto Grandis

\begin{tabular}{|c|c|c|c|c|c|c|c|c|c|c|c|}
\hline \multicolumn{6}{|c|}{ NBR 7190/97 } & \multicolumn{6}{|c|}{ LOGSDON (1998) } \\
\hline \multicolumn{2}{|c|}{$\left(\mathbf{f}_{\mathrm{c} 0, \mathrm{CCB}} / \mathbf{f}_{\mathrm{c} 0, \mathrm{p}}\right)$} & \multicolumn{2}{|c|}{$\left(\mathbf{f}_{\mathrm{v} 0, \mathrm{CCB}} / \mathbf{f}_{\mathrm{v} 0, \mathrm{p}}\right)$} & \multicolumn{2}{|c|}{$\left(\mathbf{E}_{\mathrm{c} 0, \mathrm{CCB}} / \mathbf{E}_{\mathrm{c} 0, \mathrm{p}}\right)_{\mathrm{Regr}}$} & \multicolumn{2}{|c|}{$\left(\mathbf{f}_{\mathrm{c} 0, \mathrm{CCB}} / \mathbf{f}_{\mathrm{c} 0, \mathrm{p}}\right)$} & \multicolumn{2}{|c|}{$\left(\mathbf{f}_{\mathrm{v} 0, \mathrm{CCB}} / \mathbf{f}_{\mathrm{v} 0, \mathrm{p}}\right)$} & \multicolumn{2}{|c|}{$\left(\mathbf{E}_{\mathrm{c} 0, \mathrm{CCB}} / \mathbf{E}_{\mathrm{c} 0, \mathrm{p}}\right)_{\mathrm{Regr}}$} \\
\hline Média & CV (\%) & Média & CV (\%) & Média & CV (\%) & Média & CV (\%) & Média & CV (\%) & Média & CV (\%) \\
\hline 1,06 & 6,0 & 0,95 & 14,0 & 0,96 & 11,7 & 1,05 & 5,8 & 0,96 & 14,1 & 0,96 & 10,6 \\
\hline
\end{tabular}

De acordo com a Tabela 69 e conforme as correção de umidade propostas pela NBR 7190/97 e por LOGSDON (1998), verificou-se que as médias das relações das resistências e da rigidez pouco se alteraram. O mesmo pode ser dito sobre os valores dos coeficientes de variação referentes à compressão, ao cisalhamento e à rigidez paralela às fibras.

Na compressão paralela às fibras, foi observado um aumento médio em torno de seis por cento da resistência dos CP's preservados com CCB em relação aos naturais, tomando como base as citadas correções da umidade. Verificou-se também um coeficiente de variação inferior a seis por cento. Para a rigidez, houve um decréscimo médio de aproximadamente quatro por cento e o coeficiente de variação atingiu $11 \%$. Analisando os resultados do cisalhamento paralelo, notou-se uma redução da resistência dos CP's preservados na ordem de cinco por cento. $O$ coeficiente de variação em ambos os casos atingiu a ordem de $14 \%$.

Para confirmar a confiabilidade dos valores contidos nas Tabelas 68 e 69, os conjuntos de dados das Tabelas 54, 55 e 62 foram analisados a partir do Teste de Dados Pareados.

Conforme os conjuntos de dados relativos à resistência à compressão paralela apresentados nas Tabelas 54 e 55, constatou-se que os CP's preservados com CCA e naturais submetidos a correção da umidade recomendada pela NBR 7190/97 e sugerida por LOGSDON (1998), apresentaram respectivamente, os intervalos de confiança a seguir: $\left(-4,1 \leq \mu_{x} \leq 0,8\right)$ e $\left(-4,2 \leq \mu_{x} \leq 1,0\right)$. Deste modo, concluí-se 
que tais conjuntos de dados podem ser considerados estatisticamente equivalentes. Assim sendo, em ambos os casos, é conveniente adotar um fator que desconsidere a influência do produto preservativo e do processo de tratamento nas propriedades de resistência à compressão paralela às fibras. Este fator poderá ser igual 1,0.

Conforme os dados da Tabela 62, foi considerado a equivalência estatística entre os dados dos conjuntos. Portanto, em virtude disto, é conveniente adotar para a rigidez um fator igual a 1,0. Em outras palavras, significa que o produto químico, bem como o processo de preservação não influenciou na propriedade elástica.

Para as formas de correção da umidade aqui mencionadas, foi constatado que os conjuntos de dados referentes aos CP's tratados com CCA e naturais submetidos aos ensaios de cisalhamento paralelo (ver Tabelas 54 e 55) são estatisticamente equivalentes. Esta conclusão ocorreu com base nos resultados a seguir: NBR 7190/97 $\left(-1,5 \leq \mu_{x} \leq 1,7\right)$ e LOGSDON (1998): $\left(-1,7 \leq \mu_{x} \leq 1,3\right)$. Do mesmo modo que ocorreu no caso anterior, admite-se que o produto químico e o processo de preservação não influenciarão de maneira significativa sobre a resistência ao cisalhamento paralelo às fibras. Por isso, o fator sugerido para quantificar tal efeito deve ser igual a 1,0 .

Segundo as Tabelas 54 e 55, observou-se que os conjuntos de dados relativos aos CP's preservados com $\mathrm{CCB}$ e naturais submetidos à compressão paralela (resistência) apresentaram os seguintes intervalos de confiança da média: NBR 7190/97 ( $\left.-5,7 \leq \mu_{x} \leq-0,9\right)$; LOGSDON (1998) $\left(-5,9 \leq \mu_{x} \leq-0,9\right)$. Assim sendo, concluí-se que tais conjuntos de dados não podem ser considerados estatisticamente equivalentes. Em ambos os casos é conveniente adotar um fator que considere a influência do produto preservativo e do processo de tratamento nas propriedades de resistência à compressão paralela às fibras. Este fator poderá ser igual ao valor médio apresentado na Tabela 69, isto é, 1,06 ou 1,05.

Conforme os dados da Tabela 62, obteve-se o intervalo de confiança igual a $\left(-836,0 \leq \mu_{x} \leq 2923,0\right)$ referente à correção da umidade pela NBR 7190/97. Portanto, deve-se considerar a equivalência dos conjuntos de dados. O mesmo pode ser dito para os dados submetidos à correção da umidade proposta por LOGSDON (1998). Por isto, é conveniente adotar para rigidez um fator igual a 1,0. 
Para as formas de correção da umidade aqui mencionadas, foi constatado que os conjuntos de dados referentes aos CP's tratados com CCB e naturais submetidos aos ensaios de cisalhamento paralelo (ver Tabela 54 e 55) são estatisticamente equivalentes. Esta conclusão ocorreu com base nos resultados a seguir: NBR 7190/97 $\left(-0,4 \leq \mu_{x} \leq 2,1\right)$ e LOGSDON (1998): $\left(-0,4 \leq \mu_{x} \leq 2,0\right)$. Do mesmo modo que ocorreu no caso anterior, admite-se que o produto químico e o processo de preservação não irão influenciar de maneira significativa sobre a resistência ao cisalhamento paralelo às fibras. Por isso, o fator sugerido para quantificar tal efeito deve ser igual a 1,0 .

Resumidamente, as Tabelas 70 e 71 apresentam os valores propostos a serem adotados como fatores que levem em consideração o efeito do produto e do processo preservativo nas propriedades mecânicas da madeira.

TABELA 70 - Fator K - efeito do preservativo (CCA) e do processo de tratamento nas propriedades mecânicas (amostra 02) - Eucalipto Grandis

\begin{tabular}{|c|c|c|c|c|c|}
\hline \multicolumn{3}{|c|}{ NBR 7190/97 } & \multicolumn{3}{|c|}{ LOGSDON (1998) } \\
\hline$\left(\mathbf{f}_{\mathrm{c} 0, \mathrm{CCA}} / \mathbf{f}_{\mathrm{c} 0, \mathrm{p}}\right)$ & $\left(\mathbf{f}_{\mathrm{v} 0, \mathrm{CCA}} / \mathbf{f}_{\mathrm{v} 0, \mathrm{p}}\right)$ & $\left(\mathbf{E}_{\mathrm{c} 0, \mathrm{CCA}} / \mathbf{E}_{\mathrm{c} 0, \mathrm{p}}\right)_{\operatorname{Regr}}$ & $\left(\mathbf{f}_{\mathrm{c} 0, \mathrm{CCA}} / \mathbf{f}_{\mathrm{c} 0, \mathrm{p}}\right)$ & $\left(\mathbf{f}_{\mathrm{v} 0, \mathrm{CCA}} / \mathbf{f}_{\mathrm{v} \mathbf{0}, \mathrm{p}}\right)$ & $\left(\mathrm{E}_{\mathrm{c} 0, \mathrm{CCA}} / \mathrm{E}_{\mathrm{c} 0, \mathrm{p}}\right)_{\mathrm{Regr}}$ \\
\hline 1,0 & 1,0 & 1,0 & 1,0 & 1,0 & 1,0 \\
\hline
\end{tabular}

TABELA 71 - Fator K - efeito do preservativo (CCB) e do processo de tratamento nas propriedades mecânicas (amostra 02) - Eucalipto Grandis

\begin{tabular}{|c|c|c|c|c|c|}
\hline \multicolumn{3}{|c|}{ NBR 7190/97 } & \multicolumn{3}{|c|}{ LOGSDON (1998) } \\
\hline$\left(\mathbf{f}_{\mathrm{c} 0, \mathrm{CCB}} / \mathbf{f}_{\mathrm{c} 0, \mathrm{p}}\right)$ & $\left(\mathbf{f}_{\mathrm{v} 0, \mathrm{CCB}} / \mathbf{f}_{\mathrm{v} 0, \mathrm{p}}\right)$ & $\left(\mathbf{E}_{\mathrm{c} 0, \mathrm{CCB}} / \mathbf{E}_{\mathrm{c} 0, \mathrm{p}}\right)_{\mathrm{Regr}}$ & $\left(\mathbf{f}_{\mathrm{c} 0, \mathrm{CCB}} / \mathbf{f}_{\mathrm{c} 0, \mathrm{p}}\right)$ & $\left(\mathbf{f}_{\mathrm{v} 0, \mathrm{CCB}} / \mathbf{f}_{\mathrm{v} 0, \mathrm{p}}\right)$ & $\left(\mathbf{E}_{\mathrm{c} 0, \mathrm{CCB}} / \mathbf{E}_{\mathrm{c} 0, \mathrm{p}}\right)_{\mathrm{Regr}}$ \\
\hline 1,06 & 1,0 & 1,0 & 1,05 & 1,0 & 1,0 \\
\hline
\end{tabular}




\subsubsection{Pinus Elliottii (Pinus elliottii)}

O desenvolvimento experimental para esta espécie em CP's sem preservação e em CP's preservados com CCA e com CCB, submetidos aos ensaios de compressão, de tração e de cisalhamento paralelo às fibras. Referente à compressão e ao cisalhamento paralelo, foram usados $32 \mathrm{CP}$ 's para cada tipo de ensaio, enquanto para a tração paralela utilizou-se 12 CP's.

A amostra 01, composta por $32 \mathrm{CP}$ 's de compressão paralela e $32 \mathrm{CP}$ 's de cisalhamento paralelo, foi impregnada com CCA, cujas retenções médias atingiram valores iguais a $10,2 \mathrm{~kg} / \mathrm{m}^{3}$ (compressão paralela) e $9,9 \mathrm{~kg} / \mathrm{m}^{3}$ (cisalhamento paralelo). Os 12 CP's de tração paralela às fibras também foram tratados com o mesmo produto, atingindo uma retenção média de $10,1 \mathrm{~kg} / \mathrm{m}^{3}$. Para a amostra $01 \mathrm{a}$, a preservação foi realizada com produto tipo CCB em 36 CP's, sendo 12 de compressão paralela, 12 de tração paralela e 12 de cisalhamento paralelo às fibras. Como resultado, obteve-se os seguintes valores médios de retenções: $40,9 \mathrm{~kg} / \mathrm{m}^{3}$, $40,5 \mathrm{~kg} / \mathrm{m}^{3}$ e $41,2 \mathrm{~kg} / \mathrm{m}^{3}$, respectivamente. Entretanto, a amostra $01 \mathrm{~b}$, composta por 20 CP's de compressão paralela e 20 CP's de cisalhamento paralelo, impregnada com produto tipo CCA, alcançou valores de retenções médias iguais a $10,5 \mathrm{~kg} / \mathrm{m}^{3}$ (compressão paralela) e $10,1 \mathrm{~kg} / \mathrm{m}^{3}$ (cisalhamento paralelo).

A amostra 01 completa (ou seja, 32 CP's), para os CP's naturais e preservados com CCA, destinada à compressão paralela, foi ensaiada com uma umidade média de aproximadamente 14,3 e 13,7\%, respectivamente. No cisalhamento paralelo o teor de umidade médio foi de 13,8 e 12,7\% para os CP's naturais e preservados, respectivamente. Para a mesma amostra, porém considerando os CP's PIN01 a PIN12, obteve-se os seguintes valores médios de umidade: naturais (compressão) - 13,7\%; naturais (cisalhamento) - 13,0\%; naturais (tração) - 13,8\%; preservados (compressão) - 12,9\%; preservados (cisalhamento) - 11,7\%; preservados (tração) - 10,6\%. Em contrapartida, para os CP's PIN13 a PIN32, obteve-se os seguintes valores médios de umidade: naturais (compressão) - 14,7\%; naturais (cisalhamento) - 14,3\%; preservados (compressão) - 14,2\%; preservados (cisalhamento) $-13,2 \%$.

Os CP's da amostra 01a preservados com CCB, voltados à compressão, à tração e ao cisalhamento paralelo, foram ensaiados com uma umidade média de 
aproximadamente 10,8, 10,7 e 10,1\%, respectivamente. Em contrapartida, o teor de umidade médio dos CP's preservados com CCB da amostra $01 \mathrm{~b}$, foram submetidos aos ensaios de compressão e cisalhamento paralelo com um teor de umidade em torno de 15,2 e $13,5 \%$, respectivamente.

Conforme comentado no parágrafo anterior, a retenção diferenciada do produto $\mathrm{CCB}$, fez com que os $\mathrm{CP}$ 's fossem apresentados em dois grupos, isto é: $\mathrm{CP}$ PIN-01 ao PIN-12 - amostra 01a; CP PIN-13 ao PIN-32 - amostra 01b. Para facilitar o entendimento destes dados, os mesmos foram apresentados em tabelas, sendo divididos conforme as Tabelas 75, 76, e 77 (correção da umidade - NBR 7190/97) e Tabelas 81, 82 e 83 (correção da umidade - LOGSDON (1998)). Com caráter informativo, o valor médio da massa específica aparente $\left(\rho_{12 \%}\right)$ para os CP's sem preservação é igual a $0,51 \mathrm{~g} / \mathrm{cm}^{3}$, sendo obtido a partir de cada valor individual corrigido para a umidade de $12 \%$, utilizando-se para tal o diagrama de Kollmann.

Dos ensaios realizados à compressão paralela às fibras, considerando $32 \mathrm{CP}$ 's sem preservação, levaram aos resultados das resistências características iguais a $32,7 \mathrm{MPa}$ e 33,2MPa, referente aos métodos de correção da umidade expostos pela NBR 7190/97 e por LOGSDON (1998), respectivamente. Assim sendo, verificou-se um decréscimo em torno de 1,6\%. As resistências características referentes as amostras 01a (PIN-01 a PIN-12) e 01b (PIN-13 a PIN-32) são, respectivamente, $32,5 \mathrm{MPa}$ e 31,4MPa, obtidas para a correção recomendada pela NBR 7190/97. Considerando a correção através da proposta de LOGSDON (1998), obtiveram-se valores iguais a $32,7 \mathrm{MPa}$ e $31,5 \mathrm{MPa}$ para as amostras $01 \mathrm{a}$ e $01 \mathrm{~b}$, respectivamente. Comparando os valores calculados, foi possível observar que a expressão recomendada pela NBR7190/97 gerou reduções de 0,6\% para a amostra 01a e 0,3\% para a amostra $01 b$.

Considerando a amostra total (32CP's) impregnada com CCA, obtiveram-se para a resistência característica valores iguais a $37,5 \mathrm{MPa}$ e $37,4 \mathrm{MPa}$. Daí, foi perceptível uma redução, devido a correção sugerida por LOGSDON (1998), inferior a $0,3 \%$.

Enfim, segundo a correção prescrita na NBR7190/97, as amostras 01a e 01b (CP's preservados com CCB) obtiveram valores iguais a $55,7 \mathrm{MPa}$ e $36,8 \mathrm{MPa}$, respectivamente. De acordo com a outra forma de correção, as mesmas amostras 
atingiram os seguintes resultados: 55,1 $\mathrm{MPa}$ e 37,4MPa. Diante destes resultados, percebeu-se que a resistência característica da amostra 01a, obtida de acordo com a correção da umidade recomendada pela NBR 7190/97, foi maior em aproximadamente $1 \%$, enquanto na amostra $01 \mathrm{~b}$ houve uma redução de $1,5 \%$. Portanto, a partir dos resultados alcançados, pode-se definir as referidas amostras (natural e preservada) como classe de resistência C-30. Comparando os resultados anteriores, foi constatado um acréscimo considerável dos valores das resistências características dos CP's preservados com CCA em relação aos naturais. Para a correção proposta pela NBR 7190/97 tal aumento atingiu 14,8\%, enquanto a recomendação de LOGSDON (1998) levou a 12,7\%. No que diz respeito aos CP's preservados com $\mathrm{CCB}$, também ocorreu um aumento das resistências características em relação aquelas sem tratamento. De acordo com a correção proposta pela NBR 7190/97, o acréscimo foi de 71,4\% e 17,2\%, para amostras 01a e 01b, respectivamente, enquanto a recomendação de LOGSDON (1998) levou a 68,5\% e $18,7 \%$.

Para os 32 CP's não preservados, submetidos aos ensaios de cisalhamento paralelo às fibras, foram determinadas resistências características iguais a 7,3MPa e 7,2MPa. Observou-se um acréscimo de 1,0\% para os CP's cuja correção da umidade deu-se pela expressão da NBR 7190/97. Entretanto, de acordo com o mesmo documento normativo, as resistências características referentes as amostras 01a (PIN-01 a PIN-12) e 01b (PIN-13 a PIN-32) sem preservação, atingiram valores iguais a 7,9MPa e 7,3MPa, respectivamente. Segundo a correção da umidade proposta por LOGSDON (1998), foram obtidos os seguintes valores para as amostras 01a e 01b: 7,8MPa e 7,2MPa, respectivamente. Conforme os resultados apresentados, foi possível observar que a expressão recomendada por LOGSDON (1998) gerou decréscimo de 1,3\% para a amostra 01a e 1,4\% para a amostra $01 b$. Considerando os 32 CP's preservados com CCA, as resistências características ao cisalhamento paralelo atingiram $8,1 \mathrm{MPa}$ e $8,0 \mathrm{MPa}$, segundo as correções da umidade prescritas na NBR 7190/97 e LOGSDON (1998), respectivamente. Através das recomendações normativas, a resistência característica estimada para a amostra preservada com CCA foi acrescida de aproximadamente $11,8 \%$, se comparada com a amostra natural. A segunda maneira de correção registrou um aumento em torno de 
11,2\%. Conforme as correções da umidade prescritas na NBR 7190/97, as amostras 01a e 01b compostas por CP's tratados com CCB obtiveram resistências características ao cisalhamento iguais a 9,0MPa e 7,4MPa, respectivamente. Através da correção de LOGSDON (1998), tais valores foram estimados em 9,1MPa e 7,1MPa. A partir dos resultados acima, pode-se constatar que a primeira forma de correção proporcionou à resistência característica uma redução de $1,1 \%$ para a amostra 01 a e um acréscimo de 4,2\% para a amostra 01 b. Considerando a correção da umidade conforme as prescrições da NBR 7190/97 e comparando os valores das resistências características das amostras (01a e 01b) impregnadas com CCB e naturais, obteve-se um acréscimo por parte das amostras tratadas de $14,1 \%$ e $0,7 \%$, respectivamente. Por LOGSDON (1998), houve um acréscimo de 16\% para a amostra 01 a e uma redução de $1,4 \%$ para amostra 01 b.

No que diz respeito aos ensaios de tração paralela às fibras da madeira, os CP's sem tratamento preservativo que compõem a amostra 01a levaram aos seguintes valores de resistência característica iguais a $43,7 \mathrm{MPa}$ e $43,9 \mathrm{MPa}$, considerando as correções da umidade propostas pela NBR7190/97 e LOGSDON (1998), respectivamente. Segundo as mesmas formas de correções de umidade, os CP's preservados com CCA obtiveram 41.76MPa e 41.41MPa, enquanto os CP's tratados com CCB atingiram 42,1 MPa e 42,1MPa. Dos resultados acima, pode-se constatar que a diferença entre os valores obtidos, segundo ambas as formas de correção de umidade, foi inferior a $1 \%$. Comparando os dados expostos anteriormente, pode-se verificar reduções da resistência característica à tração dos CP's preservados com CCA em relação aos CP's sem tratamento preservativo. Tais valores alcançaram $4,4 \%$ e de 5,6\%, considerando as correções propostas pela NBR7190/97 e LOGSDON (1998). De acordo com as correções mencionadas anteriormente, a relação entre os CP's tratados com CCB e os CP's naturais também apresentou redução, atingindo 3,6\% e 3,9\%, respectivamente.

As Tabelas 72, 73(a;b) e 74 apresentam resumidamente os valores acima.

TABELA 72 - Resistência característica à compressão e ao cisalhamento paralelo (amostra 01 - PIN-01 a PIN-32)

\begin{tabular}{|c|c|c|c|c|c|c|c|}
\hline \multicolumn{4}{|c|}{ Resistência à compressão } & \multicolumn{4}{|c|}{ Resistência ao cisalhamento } \\
\hline $\mathrm{NB}$ & & & 3) & NBR & & & \\
\hline $\begin{array}{l}\mathbf{f}_{\mathrm{c} 0, \mathrm{k}, \mathrm{p}} \\
(\mathrm{MPa})\end{array}$ & $\begin{array}{c}\mathbf{f}_{\mathrm{c} 0, \mathrm{k}, \mathrm{CCA}} \\
(\mathrm{MPa})\end{array}$ & $\begin{array}{c}\mathbf{f}_{\mathbf{c} 0, \mathrm{k}, \mathrm{p}} \\
(\mathrm{MPa})\end{array}$ & $\begin{array}{c}\mathbf{f}_{\mathrm{c} 0, \mathrm{k}, \mathrm{CCA}} \\
(\mathrm{MPa})\end{array}$ & $\begin{array}{l}\mathbf{f}_{\mathrm{v0}, \mathrm{k}, \mathrm{p}} \\
\text { (MPa) }\end{array}$ & $\begin{array}{c}\mathbf{f}_{\mathrm{v} 0, \mathrm{k}, \mathrm{CCA}} \\
(\mathrm{MPa})\end{array}$ & $\begin{array}{c}\mathbf{f}_{\mathrm{v0}, \mathrm{k}, \mathrm{p}} \\
(\mathrm{MPa})\end{array}$ & $\begin{array}{c}\mathbf{f}_{\mathrm{v} 0, \mathrm{k}, \mathrm{CCA}} \\
(\mathrm{MPa})\end{array}$ \\
\hline
\end{tabular}




\begin{tabular}{l|l|l|l|l|l|l|l}
32,7 & 37,5 & 33,2 & 37,4 & 7,3 & 8,1 & 7,2 & 8,0 \\
\hline
\end{tabular}

TABELA 73a - Resistência característica à compressão, à tração e ao cisalhamento paralelo (amostra 01a - PIN-01 a PIN-12) - (NBR 7190/97)

\begin{tabular}{|c|c|c|c|c|c|c|}
\hline \multicolumn{7}{|c|}{ Correção da umidade - NBR 7190/97 } \\
\hline \multicolumn{2}{|c|}{ Resistência à compressão } & \multicolumn{3}{|c|}{ Resistência à tração } & \multicolumn{2}{|c|}{ Resistência ao cisalhamento } \\
\hline $\begin{array}{c}\mathbf{f}_{\mathrm{c} 0, \mathrm{k}, \mathrm{p}} \\
(\mathrm{MPa})\end{array}$ & $\begin{array}{c}\mathbf{f}_{\mathrm{co}, \mathrm{k}, \mathrm{CCB}} \\
(\mathrm{MPa})\end{array}$ & $\begin{array}{c}\mathbf{f}_{\mathbf{t} 0, \mathrm{k}, \mathrm{p}} \\
(\mathrm{MPa})\end{array}$ & $\begin{array}{l}\mathbf{f}_{\mathrm{t} 0, \mathrm{k}, \mathrm{CCA}} \\
(\mathrm{MPa})\end{array}$ & $\begin{array}{l}\mathbf{f}_{\mathrm{t} 0, \mathrm{k}, \mathrm{CCB}} \\
(\mathrm{MPa})\end{array}$ & $\begin{array}{l}\mathbf{f}_{\mathrm{v} 0, \mathrm{k}, \mathrm{p}} \\
(\mathrm{MPa})\end{array}$ & $\begin{array}{c}\mathbf{f}_{\mathrm{v} 0, \mathrm{k}, \mathrm{CCB}} \\
(\mathrm{MPa})\end{array}$ \\
\hline 32,5 & 55,7 & 43,7 & 41,8 & 42,1 & 7,9 & 9,0 \\
\hline
\end{tabular}

TABELA 73b - Resistência característica à compressão, à tração e ao cisalhamento paralelo (amostra 01a - PIN-01 a PIN-12) - (LOGSDON (1998)

\begin{tabular}{|c|c|c|c|c|c|c|}
\hline \multicolumn{7}{|c|}{ Correção da umidade - LOGSDON (1998) } \\
\hline \multicolumn{2}{|c|}{ Resistência à compressão } & \multicolumn{3}{|c|}{ Resistência à tração } & \multicolumn{2}{|c|}{ Resistência ao cisalhamento } \\
\hline $\begin{array}{l}\mathbf{f}_{\mathrm{c} 0, \mathrm{k}, \mathrm{p}} \\
(\mathrm{MPa})\end{array}$ & $\begin{array}{c}\mathbf{f}_{\mathrm{c} 0, \mathrm{k}, \mathrm{CCB}} \\
(\mathrm{MPa})\end{array}$ & $\begin{array}{c}\mathbf{f}_{\mathbf{t 0 , k , p}} \\
(\mathbf{M P a})\end{array}$ & $\begin{array}{l}\mathbf{f}_{\mathrm{t} 0, \mathrm{k}, \mathrm{CCA}} \\
(\mathrm{MPa})\end{array}$ & $\begin{array}{l}\mathbf{f}_{\mathbf{t 0}, \mathrm{k}, \mathrm{CCB}} \\
(\mathrm{MPa})\end{array}$ & $\begin{array}{l}\mathbf{f}_{\mathrm{v} 0, \mathrm{k}, \mathrm{p}} \\
(\mathrm{MPa})\end{array}$ & $\begin{array}{l}\mathbf{f}_{\mathrm{v} 0, \mathrm{k}, \mathrm{CCB}} \\
(\mathrm{MPa})\end{array}$ \\
\hline 32,7 & 55,1 & 43,9 & 41,4 & 42,1 & 7,8 & 9,1 \\
\hline
\end{tabular}

TABELA 74 - Resistência característica à compressão e ao cisalhamento paralelo (amostra 01b - PIN-13 a PIN-32)

\begin{tabular}{|c|c|c|c|c|c|c|c|}
\hline \multicolumn{4}{|c|}{ Resistência à compressão } & \multicolumn{4}{|c|}{ Resistência ao cisalhamento } \\
\hline \multicolumn{2}{|c|}{ NBR 7190/97 } & \multicolumn{2}{|c|}{ LOGSDON (1998) } & \multicolumn{2}{|c|}{ NBR 7190/97 } & \multicolumn{2}{|c|}{ LOGSDON (1998) } \\
\hline $\begin{array}{c}\mathbf{f}_{\mathbf{c o}, \mathrm{k}, \mathrm{p}} \\
(\mathrm{MPa})\end{array}$ & $\begin{array}{c}f_{\mathrm{c} 0, \mathrm{k}, \mathrm{CCB}} \\
(\mathrm{MPa})\end{array}$ & $\begin{array}{c}\mathbf{f}_{\mathrm{c} 0, \mathrm{k}, \mathrm{p}} \\
(\mathrm{MPa})\end{array}$ & $\begin{array}{c}\mathbf{f}_{\mathrm{c} 0, \mathrm{k}, \mathrm{CCB}} \\
(\mathrm{MPa})\end{array}$ & $\begin{array}{c}\mathbf{f}_{\mathrm{v} 0, \mathrm{k}, \mathrm{p}} \\
(\mathrm{MPa})\end{array}$ & $\begin{array}{l}\mathbf{f}_{\mathrm{v} 0, \mathrm{k}, \mathrm{CCB}} \\
(\mathrm{MPa})\end{array}$ & $\begin{array}{r}\mathbf{f}_{\mathrm{v} 0, \mathrm{k}, \mathrm{p}} \\
(\mathrm{MPa}) \\
\end{array}$ & $\begin{array}{r}\mathbf{f}_{\mathrm{v} 0, \mathrm{k}, \mathrm{CCB}} \\
(\mathrm{MPa}) \\
\end{array}$ \\
\hline 31,4 & 36,8 & 31,5 & 37,4 & 7,3 & 7,4 & 7,2 & 7,1 \\
\hline
\end{tabular}

Os valores característicos apresentados nas Tabelas $72,73 \mathrm{a}$ e 74 foram calculados a partir dos resultados de cada CP ensaiado (ver Tabelas 75, 76 e 77).

TABELA 75 - Valores individuais de resistência à compressão e ao cisalhamento paralelo (amostra 01 - PIN-01 a PIN-32) - correção da umidade (NBR 7190/97)

\begin{tabular}{c|c|c|c|c}
\hline \multirow{2}{*}{ CP } & \multicolumn{2}{|c|}{$\begin{array}{c}\text { Resistência à compressão } \\
\text { (MPa) }\end{array}$} & \multicolumn{2}{c}{$\begin{array}{c}\text { Resistência ao cisalhamento } \\
\text { (MPa) }\end{array}$} \\
\cline { 2 - 5 } & Padrão & CCA & Padrão & CCA \\
\hline PIN-01 & 35,1 & 38,6 & 7,9 & 8,9 \\
PIN-02 & 46,3 & 56,8 & 11,7 & 9,9 \\
PIN-03 & 34,0 & 41,0 & 8,0 & 10,9 \\
PIN-04 & 34,1 & 42,2 & 9,0 & 11,6 \\
PIN-05 & 33,1 & 37,3 & 12,6 & 11,5 \\
PIN-06 & 44,4 & 49,6 & 11,8 & 10,8 \\
PIN-07 & 37,9 & 44,5 & 8,8 & 9,9 \\
PIN-08 & 32,4 & 40,8 & 12,0 & 10,5 \\
PIN-09 & 46,1 & 56,1 & 10,7 & 10,4 \\
PIN-10 & 39,4 & 46,6 & 11,8 & 13,7 \\
PIN-11 & 39,2 & $* * *$ & 10,6 & $* * *$ \\
\hline Continuação... & \multicolumn{3}{|c}{} \\
\hline PIN-12 & 38,8 & 46,0 & 9,1 & 10,6 \\
PIN-13 & 34,6 & 40,3 & 12,3 & 14,4 \\
PIN-14 & 41,3 & 45,6 & 14,3 & 15,1 \\
PIN-15 & 36,4 & 46,0 & 8,9 & 10,5 \\
PIN-16 & 51,2 & 54,9 & 8,9 & 11,4 \\
PIN-17 & 35,8 & 41,1 & 8,0 & 10,3
\end{tabular}




\begin{tabular}{l|l|c|c|c} 
PIN-18 & 49,8 & 54,9 & 12,5 & 13,6 \\
PIN-19 & 44,6 & 53,0 & 13,8 & 14,5 \\
PIN-20 & 39,7 & 47,5 & 10,4 & 9,0 \\
PIN-21 & 32,3 & 37,6 & 8,0 & 8,0 \\
PIN-22 & 42,4 & 52,9 & 8,4 & 8,5 \\
PIN-23 & 30,4 & 37,1 & 9,5 & 10,2 \\
PIN-24 & 49,4 & 57,1 & 11,2 & 8,4 \\
PIN-25 & 47,3 & 52,1 & 13,1 & 13,1 \\
PIN-26 & 42,0 & 52,3 & 12,4 & 11,9 \\
PIN-27 & 32,3 & 38,0 & 10,7 & 9,6 \\
PIN-28 & 45,0 & 49,3 & 13,4 & 11,0 \\
PIN-29 & 34,7 & 39,0 & 6,9 & 6,3 \\
PIN-30 & 42,8 & 47,8 & 11,1 & 8,3 \\
PIN-31 & 34,3 & 40,2 & 7,5 & 8,7 \\
PIN-32 & 36,4 & 39,7 & 7,6 & 8,9 \\
\hline
\end{tabular}

Observação: *CP PIN-11 de compressão e cisalhamento - com defeito.

TABELA 76 - Valores individuais de resistência à compressão, ao cisalhamento e à tração paralela (amostra 01a - PIN-01 a PIN-12) - correção da umidade (NBR 7190/97)

\begin{tabular}{c|c|c|c|c|c|c|c}
\hline \multirow{2}{*}{ CP } & \multicolumn{2}{|c|}{$\begin{array}{c}\text { Resistência à compressão } \\
\text { (MPa) }\end{array}$} & $\begin{array}{c}\text { Resistência ao cisalhamento } \\
\text { (MPa) }\end{array}$ & \multicolumn{3}{c}{$\begin{array}{c}\text { Resistência à tração } \\
\text { (MPa) }\end{array}$} \\
\cline { 2 - 8 } & Padrão & CCB & Padrão & CCB & Padrão & CCA & CCB \\
\hline PIN-01 & 35,1 & 56,2 & 7,9 & 9,2 & 53,3 & 50,4 & 45,4 \\
PIN-02 & 46,3 & 74,8 & 11,7 & 11,1 & 77,7 & 75,1 & 77,3 \\
PIN-03 & 34,0 & 52,7 & 8,0 & 8,7 & 34,7 & 29,6 & 37,7 \\
PIN-04 & 34,1 & 53,7 & 9,0 & 11,2 & 55,7 & 56,0 & 58,6 \\
PIN-05 & 33,1 & 51,7 & 12,6 & 12,9 & 48,0 & 48,5 & 44,1 \\
PIN-06 & 44,4 & 71,1 & 11,8 & 8,9 & 72,5 & 75,8 & 79,0 \\
PIN-07 & 37,9 & 57,7 & 8,8 & 10,9 & 55,0 & 58,6 & 57,0 \\
PIN-08 & 32,4 & 53,5 & 12,0 & 12,0 & 62,1 & 59,0 & 64,9 \\
PIN-09 & 46,1 & 68,6 & 10,7 & 10,1 & 81,8 & 80,7 & 76,2 \\
PIN-10 & 39,4 & 57,9 & 11,8 & 11,3 & $* * *$ & $* * *$ & $* * *$ \\
PIN-11 & 39,2 & 56,5 & 10,6 & 9,2 & 67,8 & 63,4 & 61,6 \\
PIN-12 & 38,8 & 57,4 & 9,1 & 9,5 & 59,7 & 59,1 & 60,3 \\
\hline
\end{tabular}

Observação: *CP PIN-10 de tração (padrão) - com defeito.

TABELA 77 - Valores individuais de resistência à compressão e ao cisalhamento paralelo (amostra 01b - PIN-13 a PIN-32) - correção da umidade (NBR 7190/97)

\begin{tabular}{c|c|c|c|c}
\hline \multirow{2}{*}{ CP } & \multicolumn{2}{|c|}{$\begin{array}{c}\text { Resistência à compressão } \\
\text { (MPa) }\end{array}$} & \multicolumn{2}{c}{$\begin{array}{c}\text { Resistência ao cisalhamento } \\
\text { (MPa) }\end{array}$} \\
\cline { 2 - 5 } & Padrão & CCB & Padrão & CCB \\
\hline PIN-13 & 34,6 & 42,9 & 12,3 & 12,0 \\
PIN-14 & 41,3 & 51,4 & 14,3 & 11,25 \\
PIN-15 & 36,4 & 40,3 & 8,9 & 8,7 \\
PIN-16 & 51,2 & 53,6 & 8,9 & 7,7 \\
PIN-17 & 35,8 & 40,4 & 8,0 & 7,7 \\
PIN-18 & 49,8 & 52,9 & 12,5 & 12,8 \\
PIN-19 & 44,6 & 50,7 & 13,8 & 11,3 \\
\hline Continuação... & \multicolumn{3}{|c}{} \\
\hline PIN-20 & 39,7 & 47,6 & 10,4 & 12,6 \\
PIN-21 & 32,3 & 37,8 & 8,0 & 8,2 \\
PIN-22 & 42,4 & 50,7 & 8,4 & 7,5 \\
PIN-23 & 30,3 & 37,7 & 9,5 & 7,4 \\
PIN-24 & 49,4 & 56,5 & 11,2 & 10,0 \\
PIN-25 & 47,3 & 53,3 & 13,1 & 12,3 \\
PIN-26 & 42,0 & 52,9 & 12,4 & 12,2
\end{tabular}




\begin{tabular}{l|l|l|c|c} 
PIN-27 & 32,3 & 41,6 & 10,7 & 9,3 \\
PIN-28 & 45,0 & 50,9 & 13,7 & 13,6 \\
PIN-29 & 34,7 & 39,2 & 6,9 & $* * *$ \\
PIN-30 & 42,8 & 52,2 & 11,1 & 11,7 \\
PIN-31 & 34,3 & 43,7 & 7,5 & 8,3 \\
PIN-32 & 36,4 & 41,1 & 7,6 & 9,5 \\
\hline
\end{tabular}

Observação: *CP PIN-29 de cisalhamento (CCB) - com defeito.

Os dados das Tabelas 75, 76 e 77 serão expressos a partir da média aritmética e do coeficiente de variação, contidos nas Tabelas 78, 79 e 80 .

TABELA 78 - Resistência à compressão e ao cisalhamento paralelo (amostra 01 PIN-01 a PIN-32) - correção da umidade (NBR 7190/97)

\begin{tabular}{|c|c|c|c|c|c|c|c|}
\hline \multicolumn{4}{|c|}{ Resistência à compressão } & \multicolumn{4}{|c|}{ Resistência ao cisalhamento } \\
\hline \multicolumn{2}{|c|}{ Padrão } & \multicolumn{2}{|c|}{ CCA } & \multicolumn{2}{|c|}{ Padrão } & \multicolumn{2}{|c|}{$\mathrm{CCA}$} \\
\hline $\mathrm{f}_{\mathrm{c} 0, \mathrm{~m}}(\mathrm{MPa})$ & CV (\%) & $\mathrm{f}_{\mathrm{c} 0, \mathrm{~m}}(\mathrm{MPa})$ & CV (\%) & $\mathrm{f}_{\mathrm{c} 0, \mathrm{~m}}(\mathrm{MPa})$ & CV (\%) & $\mathrm{f}_{\mathrm{c} 0, \mathrm{~m}}(\mathrm{MPa})$ & CV (\%) \\
\hline 39,5 & 14,9 & 46,0 & 14,3 & 10,4 & 20,3 & 10,7 & 19,7 \\
\hline
\end{tabular}

TABELA 79 - Resistência à compressão, ao cisalhamento e à tração paralela (amostra 01a - PIN-01 a PIN-12) - correção da umidade (NBR 7190/97)

\begin{tabular}{|c|c|c|c|c|c|c|c|c|c|c|c|c|c|}
\hline \multicolumn{4}{|c|}{ Resistência à compressão } & \multicolumn{4}{|c|}{ Resistência ao cisalhamento } & \multicolumn{6}{|c|}{ Resistência à tração } \\
\hline \multicolumn{2}{|c|}{ Padrão } & \multicolumn{2}{|c|}{ CCB } & \multicolumn{2}{|c|}{ Padrão } & \multicolumn{2}{|c|}{ CCB } & \multicolumn{2}{|c|}{ Padrão } & \multicolumn{2}{|c|}{ CCA } & \multicolumn{2}{|c|}{ CCB } \\
\hline $\begin{array}{c}\mathbf{f}_{\mathbf{c} 0, \mathrm{~m}} \\
(\mathbf{M P a})\end{array}$ & $\begin{array}{l}\mathrm{CV} \\
(\%)\end{array}$ & $\begin{array}{c}\mathbf{f}_{\mathrm{c} 0, \mathrm{~m}} \\
(\mathbf{M P a})\end{array}$ & $\begin{array}{l}\text { CV } \\
(\%) \\
\end{array}$ & $\begin{array}{c}\mathbf{f}_{\mathrm{v} 0, \mathrm{~m}} \\
(\mathrm{MPa})\end{array}$ & $\begin{array}{l}\mathrm{CV} \\
(\%)\end{array}$ & $\begin{array}{c}\mathbf{f}_{\mathrm{v} 0, \mathrm{~m}} \\
(\mathrm{MPa})\end{array}$ & $\begin{array}{l}\mathrm{CV} \\
(\%)\end{array}$ & $\begin{array}{c}\mathbf{f}_{\mathbf{t} 0, \mathbf{m}} \\
(\mathbf{M P a})\end{array}$ & $\begin{array}{l}\mathrm{CV} \\
(\%)\end{array}$ & $\begin{array}{c}\mathbf{f}_{\mathbf{t} 0, \mathrm{~m}} \\
(\mathrm{MPa})\end{array}$ & $\begin{array}{l}\text { CV } \\
(\%) \\
\end{array}$ & $\begin{array}{c}\mathbf{f}_{\mathbf{t} 0, \mathrm{~m}} \\
(\mathrm{MPa})\end{array}$ & $\begin{array}{l}\mathrm{CV} \\
(\%)\end{array}$ \\
\hline 38,4 & 13,0 & 59,3 & 13,0 & 10,3 & 16,5 & 10,4 & 12,8 & 60,7 & 22,6 & 59,7 & 24,2 & 60,2 & 23,1 \\
\hline
\end{tabular}

TABELA 80 - Resistência à compressão e ao cisalhamento paralelo (amostra 01b PIN-13 a PIN-32) - correção da umidade (NBR 7190/97)

\begin{tabular}{c|c|c|c|c|c|c|c}
\hline \multicolumn{3}{c|}{ Resistência à compressão } & \multicolumn{3}{c}{ Resistência ao cisalhamento } \\
\hline \multicolumn{2}{c|}{ Padrão } & \multicolumn{2}{c|}{ CCB } & \multicolumn{2}{c}{ Padrão } & \multicolumn{2}{c}{ CCB } \\
\hline $\mathbf{f}_{\mathbf{c} 0, \mathbf{m}}$ & $\mathbf{C V}$ & $\mathbf{f}_{\mathbf{c 0}, \mathbf{m}}$ & $\mathbf{C V}$ & $\mathbf{f}_{\mathbf{v} \mathbf{0}, \mathbf{m}}$ & $\mathbf{C V}$ & $\mathbf{f}_{\mathbf{v} \mathbf{0}, \mathbf{m}}$ & $\mathbf{C V}$ \\
$\mathbf{( M P a )}$ & $\mathbf{( \% )}$ & $\mathbf{( M P a )}$ & $\mathbf{( \% )}$ & $\mathbf{( M P a )}$ & $\mathbf{( \% )}$ & $(\mathbf{M P a})$ & $\mathbf{( \% )}$ \\
\hline 40,1 & 15,9 & 46,9 & 13,3 & 10,4 & 22,6 & 10,1 & 20,2 \\
\hline
\end{tabular}

Os valores característicos das Tabelas 72,73 b e 74 foram calculados a partir dos resultados das Tabelas 81, 82 e 83, conforme mostrados abaixo.

TABELA 81 - Valores individuais de resistência à compressão e ao cisalhamento paralelo (amostra 01 - PIN-01 a PIN-32) - correção da umidade (LOGSDON (1998))

\begin{tabular}{c|c|c|c|c}
\hline \multirow{2}{*}{ CP } & \multicolumn{2}{|c|}{$\begin{array}{c}\text { Resistência à compressão } \\
\text { (MPa) }\end{array}$} & \multicolumn{2}{|c}{$\begin{array}{c}\text { Resistência ao cisalhamento } \\
\text { (MPa) }\end{array}$} \\
\cline { 2 - 5 } & Padrão & CCA & Padrão & CCA \\
\hline PIN-01 & 35,2 & 38,9 & 7,8 & 8,8 \\
PIN-02 & 46,8 & 56,8 & 11,6 & 10,0 \\
PIN-03 & 34,2 & 41,2 & 7,9 & 10,8
\end{tabular}




\begin{tabular}{l|l|c|c|c} 
PIN-04 & 34,3 & 42,5 & 8,9 & 11,6 \\
PIN-05 & 33,4 & 37,3 & 12,5 & 11,6 \\
PIN-06 & 44,9 & 49,8 & 11,7 & 10,8 \\
PIN-07 & 38,2 & 44,8 & 8,7 & 10,0 \\
PIN-08 & 32,7 & 41,0 & 11,9 & 10,5 \\
PIN-09 & 46,1 & 56,4 & 10,7 & 10,5 \\
PIN-10 & 39,9 & 46,8 & 11,8 & 13,8 \\
PIN-11 & 39,7 & $* * *$ & 10,5 & $* * *$ \\
PIN-12 & 39,0 & 46,2 & 9,1 & 10,6 \\
PIN-13 & 35,0 & 40,6 & 12,1 & 14,3 \\
PIN-14 & 42,7 & 46,2 & 14,0 & 15,0 \\
PIN-15 & 36,9 & 46,5 & 8,8 & 10,5 \\
PIN-16 & 51,9 & 55,7 & 8,8 & 11,3 \\
PIN-17 & 36,2 & 41,5 & 7,9 & 10,2 \\
PIN-18 & 50,5 & 55,6 & 12,4 & 13,6 \\
PIN-19 & 45,2 & 53,7 & 13,6 & 14,4 \\
PIN-20 & 40,3 & 48,1 & 10,3 & 8,9 \\
PIN-21 & 32,7 & 38,0 & 7,9 & 8,0 \\
PIN-22 & 43,0 & 53,4 & 8,3 & 8,4 \\
PIN-23 & 30,6 & 37,5 & 9,5 & 10,2 \\
PIN-24 & 50,2 & 57,7 & 11,1 & 8,4 \\
PIN-25 & 47,7 & 52,7 & 12,9 & 13,0 \\
PIN-26 & 42,7 & 53,0 & 12,3 & 11,8 \\
PIN-27 & 32,6 & 38,2 & 10,6 & 9,6 \\
PIN-28 & 45,5 & 49,5 & 13,3 & 10,9 \\
PIN-29 & 35,2 & 39,3 & 6,8 & 6,2 \\
PIN-30 & 43,2 & 48,1 & 11,0 & 8,3 \\
PIN-31 & 34,6 & 40,6 & 7,5 & 8,6 \\
PIN-32 & 36,7 & 39,9 & 7,5 & 8,8 \\
\hline
\end{tabular}

Observação: *CP PIN-11 de cisalhamento (CCA) - com defeito.

TABELA 82 - Valores individuais de resistência à compressão, ao cisalhamento e à tração paralela (amostra 01a - PIN-01 a PIN-12) - correção da umidade (LOGSDON (1998))

\begin{tabular}{c|c|c|c|c|c|c|c}
\hline \multirow{2}{*}{ CP } & \multicolumn{2}{|c|}{$\begin{array}{c}\text { Resistência à compressão } \\
\text { (MPa) }\end{array}$} & \multicolumn{2}{c|}{$\begin{array}{c}\text { Resistência ao cisalhamento } \\
\text { (MPa) }\end{array}$} & \multicolumn{2}{c}{$\begin{array}{c}\text { Resistência à tração } \\
\text { (MPa) }\end{array}$} \\
\cline { 2 - 8 } & Padrão & CCB & Padrão & CCB & Padrão & CCA & CCB \\
\hline PIN-01 & 35,2 & 55,6 & 7,8 & 9,3 & 53,4 & 49,9 & 45,3 \\
PIN-02 & 46,8 & 74,0 & 11,6 & 11,2 & 77,7 & 74,5 & 77,4 \\
PIN-03 & 34,2 & 52,1 & 7,9 & 8,8 & 34,7 & 29,4 & 37,8 \\
PIN-04 & 34,3 & 53,1 & 8,9 & 11,3 & 55,6 & 55,3 & 58,4 \\
PIN-05 & 33,4 & 51,2 & 12,5 & 13,0 & 47,9 & 48,1 & 44,0 \\
PIN-06 & 44,9 & 70,3 & 11,7 & 9,0 & 72,5 & 75,2 & 79,1 \\
PIN-07 & 38,2 & 57,0 & 8,7 & 11,1 & 55,0 & 57,9 & 56,9 \\
PIN-08 & 32,7 & 52,9 & 11,9 & 12,1 & 62,1 & 58,9 & 64,8 \\
PIN-09 & 46,1 & 67,8 & 10,7 & 10,2 & 82,0 & 80,2 & 76,4 \\
PIN-10 & 39,9 & 57,3 & 11,8 & 11,4 & $* * *$ & $* * *$ & $* * *$ \\
PIN-11 & 39,7 & 55,9 & 10,5 & 9,3 & 67,9 & 62,8 & 61,7 \\
PIN-12 & 39,0 & 56,8 & 9,1 & 9,6 & 59,9 & 58,4 & 60,3 \\
\hline
\end{tabular}

Observação: *CP PIN-10 de tração (padrão) - com defeito.

TABELA 83 - Valores individuais de resistência à compressão e ao cisalhamento paralelo (amostra 01b - PIN-13 a PIN-32) - correção da umidade (LOGSDON (1998))

\begin{tabular}{c|c|c|c|c}
\hline \multirow{2}{*}{ CP } & \multicolumn{2}{|c|}{$\begin{array}{c}\text { Resistência à compressão } \\
\text { (MPa) }\end{array}$} & $\begin{array}{c}\text { Resistência ao cisalhamento } \\
\text { (MPa) }\end{array}$ \\
\cline { 2 - 5 } & Padrão & CCB & Padrão & CCB \\
\hline PIN-13 & 35,0 & 44,1 & 12,1 & 11,5
\end{tabular}




\begin{tabular}{l|l|l|c|c} 
PIN-14 & 42,7 & 51,7 & 14,0 & 10,7 \\
PIN-15 & 36,9 & 41,0 & 8,8 & 8,3 \\
PIN-16 & 51,9 & 55,0 & 8,8 & 7,3 \\
PIN-17 & 36,2 & 41,2 & 7,9 & 7,2 \\
PIN-18 & 50,5 & 54,1 & 12,4 & 12,5 \\
PIN-19 & 45,2 & 51,9 & 13,6 & 10,9 \\
PIN-20 & 40,3 & 48,3 & 10,3 & 12,1 \\
PIN-21 & 32,7 & 38,3 & 7,9 & 7,8 \\
PIN-22 & 43,0 & 51,7 & 8,3 & 7,1 \\
PIN-23 & 30,6 & 37,9 & 9,5 & 7,1 \\
PIN-24 & 50,2 & 57,2 & 11,1 & 9,7 \\
PIN-25 & 47,7 & 54,0 & 12,9 & 11,8 \\
PIN-26 & 42,7 & 53,5 & 12,3 & 11,6 \\
PIN-27 & 32,6 & 42,3 & 10,6 & 8,9 \\
PIN-28 & 45,5 & 51,6 & 13,3 & 13,0 \\
PIN-29 & 35,2 & 39,8 & 6,8 & $* * *$ \\
PIN-30 & 43,2 & 52,7 & 11,0 & 11,3 \\
PIN-31 & 34,6 & 44,0 & 7,5 & 8,0 \\
PIN-32 & 36,7 & 41,7 & 7,5 & 8,9 \\
\hline
\end{tabular}

Observação: *CP PIN-29 de cisalhamento (CCB) - com defeito.

As Tabelas 84, 85 e 86 expressam, através da média aritmética e do coeficiente de variação, os resultados apresentados nas Tabelas 81, 82 e 83, respectivamente.

TABELA 84 - Resistência à compressão e ao cisalhamento paralelo (amostra 01PIN-01 a PIN-32) - correção da umidade (LOGSDON (1998))

\begin{tabular}{|c|c|c|c|c|c|c|c|}
\hline \multicolumn{4}{|c|}{ Resistência à compressão } & \multicolumn{4}{|c|}{ Resistência ao cisalhamento } \\
\hline \multicolumn{2}{|c|}{ Padrão } & \multicolumn{2}{|c|}{$\mathrm{CCA}$} & \multicolumn{2}{|c|}{ Padrão } & \multicolumn{2}{|c|}{$\mathbf{C C A}$} \\
\hline $\mathbf{f}_{\mathrm{c} 0, \mathrm{~m}}(\mathrm{MPa})$ & CV (\%) & $\mathrm{f}_{\mathrm{c} 0, \mathrm{~m}}(\mathrm{MPa})$ & CV (\%) & $\mathrm{f}_{\mathrm{c} 0, \mathrm{~m}}(\mathrm{MPa})$ & CV (\%) & $\mathrm{f}_{\mathrm{c} 0, \mathrm{~m}}(\mathrm{MPa})$ & CV (\%) \\
\hline 39,9 & 15,0 & 46,4 & 14,4 & 10,3 & 20,1 & 10,6 & 19,8 \\
\hline
\end{tabular}

TABELA 85 - Resistência à compressão, ao cisalhamento e à tração paralela (amostra 01a - PIN-01 a PIN-12) - correção da umidade (LOGSDON (1998))

\begin{tabular}{|c|c|c|c|c|c|c|c|c|c|c|c|c|c|}
\hline \multicolumn{4}{|c|}{ Resistência à compressão } & \multicolumn{4}{|c|}{ Resistência ao cisalhamento } & \multicolumn{6}{|c|}{ Resistência à tração } \\
\hline \multicolumn{2}{|c|}{ Padrão } & \multicolumn{2}{|c|}{ CCB } & \multicolumn{2}{|c|}{ Padrão } & \multicolumn{2}{|c|}{ CCB } & \multicolumn{2}{|c|}{ Padrão } & \multicolumn{2}{|c|}{ CCA } & \multicolumn{2}{|c|}{ CCB } \\
\hline $\begin{array}{c}\mathbf{f}_{\mathrm{c} 0, \mathrm{~m}} \\
(\mathrm{MPa})\end{array}$ & $\begin{array}{l}\text { CV } \\
(\%) \\
\end{array}$ & $\begin{array}{c}\mathbf{f}_{\mathbf{c} 0, m} \\
(\mathbf{M P a})\end{array}$ & $\begin{array}{l}\text { CV } \\
(\%)\end{array}$ & $\begin{array}{c}\mathbf{f}_{\mathrm{v} 0, \mathrm{~m}} \\
(\mathrm{MPa})\end{array}$ & $\begin{array}{l}\text { CV } \\
(\%) \\
\end{array}$ & $\begin{array}{c}\mathbf{f}_{\mathrm{v} 0, \mathrm{~m}} \\
(\mathrm{MPa})\end{array}$ & $\begin{array}{l}\text { CV } \\
(\%)\end{array}$ & $\begin{array}{c}\mathbf{f}_{\mathbf{t} 0, \mathrm{~m}} \\
(\mathrm{MPa})\end{array}$ & $\begin{array}{l}\text { CV } \\
(\%) \\
\end{array}$ & $\begin{array}{c}\mathbf{f}_{\mathbf{t} 0, \mathbf{m}} \\
(\mathrm{MPa})\end{array}$ & $\begin{array}{l}\text { CV } \\
(\%)\end{array}$ & $\begin{array}{c}\mathbf{f}_{\mathbf{t} 0, \mathbf{m}} \\
(\mathrm{MPa})\end{array}$ & $\begin{array}{l}\text { CV } \\
(\%) \\
\end{array}$ \\
\hline 38,7 & 13,0 & 58,7 & 13,0 & 10,3 & 16,4 & 10,5 & 12,8 & 60,8 & 22,6 & 59,2 & 24,3 & 60,2 & 23,1 \\
\hline
\end{tabular}

TABELA 86 - Resistência à compressão e ao cisalhamento paralelo (amostra 01b PIN-13 a PIN-32) - correção da umidade (LOGSDON (1998))

\begin{tabular}{|c|c|c|c|c|c|c|c|}
\hline \multicolumn{4}{|c|}{ Resistência à compressão } & \multicolumn{4}{|c|}{ Resistência ao cisalhamento } \\
\hline \multicolumn{2}{|c|}{ Padrão } & \multicolumn{2}{|c|}{ CCB } & \multicolumn{2}{|c|}{ Padrão } & \multicolumn{2}{|c|}{ CCB } \\
\hline $\begin{array}{c}\mathbf{f}_{\mathrm{co}, \mathrm{m}} \\
(\mathrm{MPa})\end{array}$ & $\begin{array}{l}\text { CV } \\
(\%)\end{array}$ & $\begin{array}{c}\mathbf{f}_{\mathrm{c} 0, \mathrm{~m}} \\
(\mathrm{MPa})\end{array}$ & $\begin{array}{l}\text { CV } \\
(\%)\end{array}$ & $\begin{array}{c}\mathbf{f}_{\mathrm{v} 0, \mathrm{~m}} \\
(\mathbf{M P a})\end{array}$ & $\begin{array}{l}\text { CV } \\
(\%)\end{array}$ & $\begin{array}{c}\mathbf{f}_{\mathrm{v} 0, \mathrm{~m}} \\
(\mathbf{M P a})\end{array}$ & $\begin{array}{l}\text { CV } \\
(\%)\end{array}$ \\
\hline 40,7 & 16,0 & 47,6 & 13,4 & 10,3 & 22,5 & 9,8 & 21,1 \\
\hline
\end{tabular}


Segundo os resultados apresentados na Tabela 78, obtidos para a amostra com 32 CP's, verificou-se para os CP's naturais e preservados (CCA) submetidos à compressão e ao cisalhamento paralelo às fibras, uma diferença entre os coeficientes de variação de aproximadamente $0,6 \%$ em ambos os casos. De acordo com a Tabela 84 , tais diferenças atingiram 0,6 e $0,4 \%$.

Para os valores contidos nas Tabelas 79 e 85 (amostra 01a), referente aos CP's naturais e preservados (CCB) submetidos à compressão, ao cisalhamento e à tração paralela às fibras, observaram-se diferenças para o coeficiente de variação inferiores a 0,1, 3,6 e 0,6\%, respectivamente. A diferença entre os coeficientes de variação dos CP's preservados com CCA e sem preservação, ensaiados à tração paralela às fibras, chegou a $1,6 \%$.

Conforme os dados da amostra 01b (Tabela 80), tais diferenças atingiram aproximadamente $2,6 \%$ para a compressão para o cisalhamento paralelo às fibras, enquanto os valores da Tabela 86 , alcançaram 2,6 e 1,4\%, respectivamente.

Assim sendo, pode-se admitir que os resultados não foram influenciados de maneira relevante devido a anisotropia do material.

Referente ao módulo de elasticidade longitudinal, a análise dos resultados para o Pinus Elliottii, assim como para as demais espécies já discutidas, foram realizadas segundo as recomendações da NBR 7190/97 - Anexo B (Item 8) e através de uma regressão linear simples. A Figura 22 ilustra o resultado do módulo de elasticidade obtido através da regressão linear.

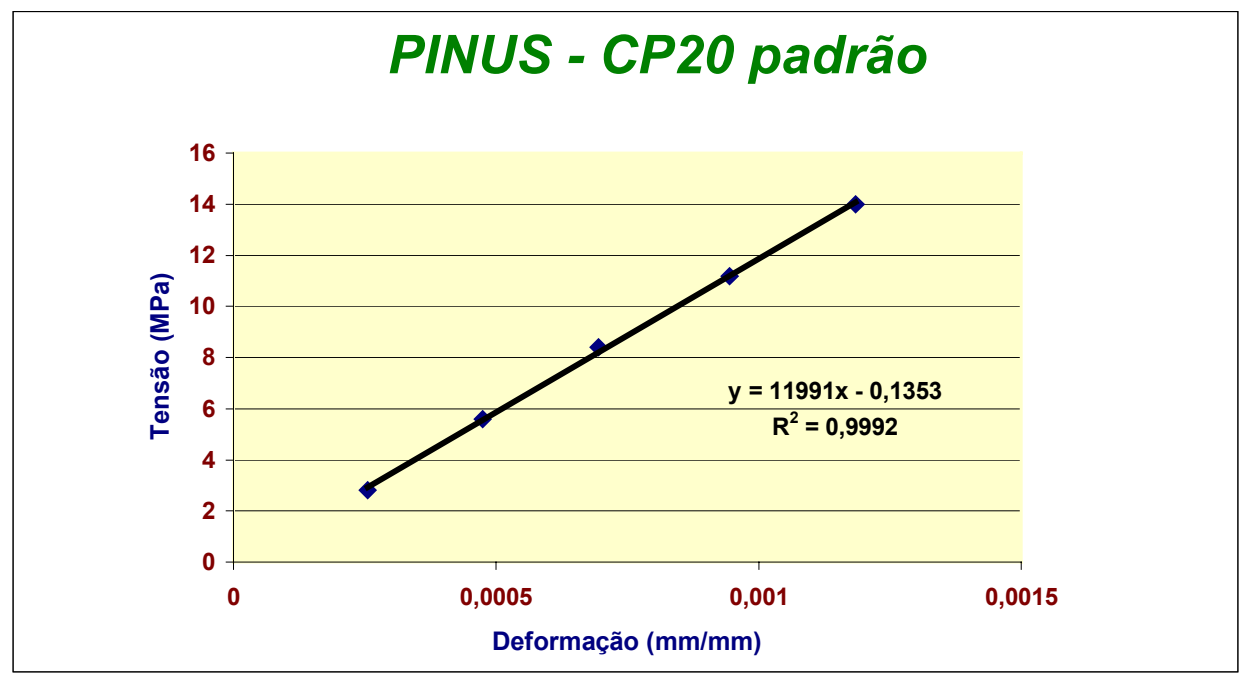

FIGURA 22 - Módulo de elasticidade longitudinal do Pinus Elliottii (regressão linear simples) 
Os valores da rigidez de cada $\mathrm{CP}$, resultantes da correção segundo a NBR 7190/97, estão apresentados nas Tabelas 87, 88 e 89. Todavia, os dados corrigidos conforme a proposta de LOGSDON (1998), encontram-se nas Tabelas 90, 91 e 92.

TABELA 87 - Valores individuais de rigidez à compressão paralela (amostra 01PIN-01 a PIN-32) - correção da umidade (NBR 7190/97)

\begin{tabular}{|c|c|c|c|c|c|c|}
\hline \multirow{3}{*}{$\mathbf{C P}$} & \multicolumn{6}{|c|}{ Correção da umidade - NBR 7190/97 } \\
\hline & \multicolumn{3}{|c|}{ Padrão } & \multicolumn{3}{|c|}{ CCA } \\
\hline & $\begin{array}{c}\mathbf{E}_{\mathrm{c} 0, \mathrm{NBR}} \\
(\mathrm{MPa})\end{array}$ & $\begin{array}{l}\mathbf{E}_{\text {c0,Regr }} \\
\text { (MPa) }\end{array}$ & $\begin{array}{c}\Delta \\
(\%)\end{array}$ & $\begin{array}{l}\mathbf{E}_{\mathrm{c} 0, \mathrm{NBR}} \\
\text { (MPa) }\end{array}$ & $\begin{array}{l}\mathbf{E}_{\mathrm{c0}, \mathrm{Regr}} \\
(\mathrm{MPa})\end{array}$ & $\begin{array}{c}\Delta \\
(\%)\end{array}$ \\
\hline PIN-01 & 10143 & 10092 & $-0,5$ & 9144 & 8971 & $-1,9$ \\
\hline PIN-02 & 14085 & 14020 & $-0,4$ & 15156 & 15180 & 0,2 \\
\hline PIN-03 & 8135 & 8140 & 0,1 & 9020 & 8963 & $-0,6$ \\
\hline PIN-04 & 6596 & 6591 & $-0,0$ & 70529 & 7069 & 0,3 \\
\hline PIN-05 & 6056 & 6078 & 0,4 & 6107 & 6006 & $-1,7$ \\
\hline PIN-06 & 14797 & 14666 & $-0,9$ & 14852 & 14313 & $-3,6$ \\
\hline PIN-07 & 10298 & 10208 & $-0,9$ & 12072 & 11796 & $-2,3$ \\
\hline PIN-08 & 7297 & 7285 & $-0,2$ & 9952 & 9554 & $-4,0$ \\
\hline PIN-09 & 16325 & 15514 & $-5,0$ & 15008 & 15004 & $-0,0$ \\
\hline PIN-10 & 11216 & 11165 & $-0,5$ & 9648 & 9634 & $-0,2$ \\
\hline PIN-11 & 9916 & 9746 & $-1,7$ & *** & *** & $* * *$ \\
\hline PIN-12 & 10997 & 11014 & 0,2 & 13682 & 13282 & $-2,9$ \\
\hline PIN-13 & 8261 & 8212 & $-0,6$ & 9289 & 8975 & $-3,4$ \\
\hline PIN-14 & 174659 & 16126 & $-7,7$ & 16541 & 16458 & $-0,5$ \\
\hline PIN-15 & 98538 & 9758 & $-1,0$ & 9140 & 8968 & $-1,9$ \\
\hline PIN-16 & 11006 & 11032 & 0,2 & 12249 & 12185 & $-0,5$ \\
\hline PIN-17 & 10927 & 10902 & $-0,2$ & 10109 & 10122 & 0,1 \\
\hline PIN-18 & 11937 & 11713 & $-1,9$ & 11117 & 11108 & $-0,1$ \\
\hline PIN-19 & 12616 & 12564 & $-0,4$ & 12925 & 12874 & $-0,4$ \\
\hline PIN-20 & 12909 & 12878 & $-0,2$ & 11577 & 11657 & 0,7 \\
\hline PIN-21 & 9631 & 9523 & $-1,1$ & 8655 & 8670 & 0,2 \\
\hline PIN-22 & 15785 & 15550 & $-1,5$ & 14410 & 14486 & 0,5 \\
\hline PIN-23 & 9367 & 9370 & 0,1 & 9142 & 9193 & 0,6 \\
\hline PIN-24 & 19514 & 19435 & $-0,4$ & 18044 & 16962 & $-6,0$ \\
\hline PIN-25 & 14033 & 13993 & $-0,3$ & 12599 & 12646 & 0,4 \\
\hline \multicolumn{7}{|c|}{ Continuação... } \\
\hline PIN-26 & 16224 & 16180 & $-0,3$ & 15727 & 15367 & $-2,3$ \\
\hline PIN-27 & 7461 & 7283 & $-2,4$ & 8925 & 8853 & $-0,8$ \\
\hline PIN-28 & 12649 & 12174 & $-3,8$ & 12888 & 12853 & $-0,3$ \\
\hline PIN-29 & 8177 & 7901 & $-3,4$ & 8341 & 8387 & 0,6 \\
\hline PIN-30 & 13224 & 13170 & $-0,4$ & 11952 & 11873 & 0,7 \\
\hline PIN-31 & 8427 & 8418 & $-0,1$ & 8519 & 8504 & $-0,2$ \\
\hline PIN-32 & 8989 & 8971 & $-0,2$ & 83547 & 8430 & 0,9 \\
\hline
\end{tabular}

Observação: CP PIN11 (CCA) - com defeito.

TABELA 88 - Valores individuais de rigidez à compressão paralela (amostra 01a PIN-01 a PIN-12) - correção da umidade (NBR 7190/97

\begin{tabular}{c|c|c|c|c|c|c}
\hline \multirow{2}{*}{ CP } & \multicolumn{5}{|c}{ Correção da umidade - NBR 7190/97 } \\
\cline { 2 - 7 } & \multicolumn{3}{|c|}{ Padrão } & \multicolumn{3}{c}{ CCB } \\
\cline { 2 - 7 } & $\begin{array}{c}\mathbf{E}_{\mathbf{c 0 , N B R}} \\
(\mathbf{M P a})\end{array}$ & $\begin{array}{c}\mathbf{E}_{\mathbf{c 0 , R e g r}} \\
\mathbf{( M P a )}\end{array}$ & $\begin{array}{c}\Delta \\
\mathbf{( \% )}\end{array}$ & $\begin{array}{c}\mathbf{E}_{\mathbf{c 0 , N B R}} \\
\mathbf{( M P a )}\end{array}$ & $\begin{array}{c}\mathbf{E}_{\mathbf{c 0 , R e g r}} \\
(\mathbf{M P a})\end{array}$ & $\begin{array}{c}\Delta \\
(\%)\end{array}$ \\
\hline PIN-01 & 10143 & 10092 & $-0,5$ & 8911 & 8942 & 0,3 \\
PIN-02 & 14085 & 14020 & $-0,4$ & 15606 & 15668 & 0,4 \\
PIN-03 & 8135 & 8140 & 0,1 & 6563 & 6530 & $-0,5$ \\
PIN-04 & 6596 & 6591 & 0,0 & 6959 & 6860 & $-1,4$ \\
PIN-05 & 6056 & 6078 & 0,4 & 6032 & 5997 & $-0,6$
\end{tabular}




\begin{tabular}{c|c|c|c|c|c|c} 
PIN-06 & 14797 & 14666 & $-0,9$ & 15207 & 14292 & $-6,0$ \\
PIN-07 & 10298 & 10208 & $-0,87$ & 10512 & 10100 & $-3,9$ \\
PIN-08 & 7297 & 7285 & $-0,2$ & 8689 & 8596 & $-1,1$ \\
PIN-09 & 16325 & 15515 & $-5,0$ & 15912 & 14586 & $-8,3$ \\
PIN-10 & 11216 & 11165 & $-0,5$ & 9063 & 9022 & $-0,5$ \\
PIN-11 & 9916 & 9746 & $-1,7$ & 8222 & 8067 & $-1,9$ \\
PIN-12 & 10997 & 11014 & 0,2 & 12232 & 11891 & $-2,8$ \\
\hline
\end{tabular}

TABELA 89 - Valores individuais de rigidez à compressão paralela (amostra 01b PIN-13 a PIN-32) - correção da umidade (NBR 7190/97)

\begin{tabular}{|c|c|c|c|c|c|c|}
\hline \multirow{3}{*}{$\mathbf{C P}$} & \multicolumn{6}{|c|}{ Correção da umidade - NBR 7190/97 } \\
\hline & \multicolumn{3}{|c|}{ Padrão } & \multicolumn{3}{|c|}{ CCB } \\
\hline & $\begin{array}{l}\mathbf{E}_{\mathbf{c 0}, \mathrm{NBR}} \\
(\mathrm{MPa})\end{array}$ & $\begin{array}{l}\mathbf{E}_{\mathbf{c 0}, \text { Regr }} \\
(\mathrm{MPa})\end{array}$ & $\begin{array}{c}\Delta \\
(\%)\end{array}$ & $\begin{array}{l}\mathbf{E}_{\mathrm{c} 0, \mathrm{NBR}} \\
(\mathrm{MPa})\end{array}$ & $\begin{array}{l}\mathbf{E}_{\mathbf{c 0}, \mathrm{Regr}} \\
(\mathrm{MPa})\end{array}$ & $\begin{array}{c}\Delta \\
(\%)\end{array}$ \\
\hline PIN-13 & 8261 & 8212 & $-0,6$ & 8687 & 8671 & $-0,2$ \\
\hline PIN-14 & 17465 & 16126 & $-7,7$ & 16035 & 16305 & 1,7 \\
\hline PIN-15 & 9853 & 9758 & $-1,0$ & 9840 & 9806 & $-0,4$ \\
\hline PIN-16 & 11006 & 11032 & 0,2 & 12798 & 12800 & 0,0 \\
\hline PIN-17 & 10927 & 10902 & $-0,2$ & 9652 & 9644 & $-0,1$ \\
\hline PIN-18 & 11937 & 11713 & $-1,9$ & 13049 & 12871 & $-1,4$ \\
\hline PIN-19 & 12616 & 12564 & $-0,4$ & 11458 & 11427 & $-0,3$ \\
\hline PIN-20 & 12909 & 12878 & $-0,2$ & 12639 & 12464 & $-1,4$ \\
\hline PIN-21 & 9631 & 9523 & $-1,1$ & 8239 & 7908 & $-4,0$ \\
\hline PIN-22 & 15785 & 15550 & $-1,5$ & 15618 & 15332 & $-1,8$ \\
\hline PIN-23 & 9367 & 9370 & 0,1 & 8857 & 8778 & $-0,9$ \\
\hline PIN-24 & 19514 & 19435 & $-0,4$ & 18411 & 18307 & $-0,6$ \\
\hline PIN-25 & 14033 & 13993 & $-0,3$ & 12193 & 12074 & $-1,0$ \\
\hline PIN-26 & 16224 & 16180 & $-0,3$ & 17656 & 17204 & $-2,6$ \\
\hline PIN-27 & 7461 & 7283 & $-2,4$ & 9278 & 9060 & $-2,4$ \\
\hline PIN-28 & 12649 & 12174 & $-3,8$ & 12040 & 12132 & 0,8 \\
\hline PIN-29 & 8177 & 7901 & $-3,4$ & 8261 & 8235 & $-0,3$ \\
\hline PIN-30 & 13224 & 13170 & $-0,4$ & 13543 & 13388 & $-1,1$ \\
\hline PIN-31 & 8427 & 8418 & $-0,1$ & 10151 & 9745 & $-4,0$ \\
\hline PIN-32 & 8989 & 8971 & $-0,2$ & 7915 & 7855 & $-0,8$ \\
\hline
\end{tabular}

TABELA 90 - Valores individuais de rigidez à compressão paralela (amostra 01PIN-01 a PIN-32) - correção da umidade (LOGSDON (1998))

\begin{tabular}{c|c|c|c|c|c|c}
\hline \multirow{2}{*}{ CP } & \multicolumn{5}{|c}{ Correção da umidade - LOGSDON (1998) } \\
\cline { 2 - 7 } & \multicolumn{3}{|c|}{ Padrão } & \multicolumn{3}{c}{ CCA } \\
\cline { 2 - 7 } & $\begin{array}{c}\mathbf{E}_{\mathbf{c 0 , N B R}} \\
(\mathbf{M P a})\end{array}$ & $\begin{array}{c}\mathbf{E}_{\mathbf{c 0 , R e g r}} \\
\mathbf{( M P a )}\end{array}$ & $\begin{array}{c}\Delta \\
\mathbf{( \% )}\end{array}$ & $\begin{array}{c}\mathbf{E}_{\mathbf{c 0 , N B R}} \\
\mathbf{( M P a )}\end{array}$ & $\begin{array}{c}\mathbf{E}_{\mathbf{c 0 , R e g r}} \\
\mathbf{( M P a )}\end{array}$ & $\begin{array}{c}\Delta \\
(\%)\end{array}$ \\
\hline PIN-01 & 10168 & 10117 & $-0,5$ & 9211 & 9036 & $-1,9$ \\
PIN-02 & 14230 & 14168 & $-0,4$ & 15156 & 15180 & 0,2 \\
PIN-03 & 8198 & 8203 & 0,1 & 9073 & 9016 & $-0,6$ \\
PIN-04 & 6642 & 6639 & 0,0 & 7103 & 7121 & 0,3 \\
PIN-05 & 6123 & 6145 & 0,4 & 6104 & 6003 & $-1,7$ \\
PIN-06 & 14953 & 14821 & $-0,9$ & 14925 & 14383 & $-3,6$ \\
PIN-07 & 10383 & 10292 & $-0,9$ & 12143 & 11865 & $-2,3$ \\
PIN-08 & 7357 & 7345 & $-0,2$ & 9986 & 9587 & $-4,0$ \\
PIN-09 & 16349 & 15538 & $-5,0$ & 15088 & 15085 & 0,0 \\
PIN-10 & 11365 & 11313 & $-0,5$ & 9691 & 9676 & $-0,2$ \\
PIN-11 & 10052 & 9880 & $-1,7$ & $* * *$ & $* * *$ & $* * *$ \\
PIN-12 & 11045 & 11064 & 0,2 & 13749 & 13348 & $-2,9$ \\
PIN-13 & 8349 & 8299 & $-0,6$ & 9365 & 9049 & $-3,4$ \\
PIN-14 & 18067 & 16682 & $-7,7$ & 16775 & 16691 & $-0,5$ \\
PIN-15 & 9991 & 9896 & $-1,0$ & 9236 & 9063 & $-1,9$ \\
PIN-16 & 1153 & 11178 & 0,2 & 12428 & 12363 & $-0,5$ \\
PIN-17 & 11064 & 11041 & $-0,2$ & 10220 & 10234 & 0,1 \\
PIN-18 & 12095 & 11868 & $-1,9$ & 11270 & 11260 & $-0,1$
\end{tabular}




\begin{tabular}{l|c|c|c|c|c|c} 
PIN-19 & 12805 & 12753 & $-0,4$ & 13114 & 13062 & $-0,4$ \\
PIN-20 & 13129 & 13100 & $-0,2$ & 11726 & 11807 & 0,7 \\
PIN-21 & 9744 & 9636 & $-1,1$ & 8762 & 8777 & 0,2 \\
PIN-22 & 16046 & 15805 & $-1,5$ & 14556 & 14632 & 0,5 \\
PIN-23 & 9455 & 9460 & 0,1 & 9222 & 9273 & 0,6 \\
PIN-24 & 19840 & 19762 & $-0,4$ & 18251 & 17156 & $-6,0$ \\
PIN-25 & 14172 & 14134 & $-0,3$ & 12749 & 12797 & 0,4 \\
PIN-26 & 16489 & 16444 & $-0,3$ & 15928 & 15564 & $-2,3$ \\
PIN-27 & 7548 & 7367 & $-2,4$ & 8981 & 8909 & $-0,8$ \\
PIN-28 & 12793 & 12313 & $-3,8$ & 12952 & 12916 & $-0,3$ \\
PIN-29 & 8276 & 7999 & $-3,4$ & 8390 & 8436 & 0,6 \\
PIN-30 & 13357 & 13303 & $-0,4$ & 12045 & 11965 & 0,7 \\
PIN-31 & 8498 & 8487 & $-0,1$ & 8609 & 8593 & $-0,2$ \\
PIN-32 & 9063 & 9045 & $-0,2$ & 8399 & 8475 & 0,9 \\
\hline
\end{tabular}

Observação: CP PIN11 (CCA) - com defeito.

TABELA 91 - Valores individuais de rigidez à compressão paralela (amostra 01a PIN-01 a PIN-12) - correção da umidade (LOGSDON (1998))

\begin{tabular}{|c|c|c|c|c|c|c|}
\hline \multirow{3}{*}{$\mathbf{C P}$} & \multicolumn{6}{|c|}{ Correção da umidade - LOGSDON (1998) } \\
\hline & \multicolumn{3}{|c|}{ Padrão } & \multicolumn{3}{|c|}{ CCB } \\
\hline & $\begin{array}{l}\mathbf{E}_{\mathrm{c} 0, \mathrm{NBR}} \\
(\mathrm{MPa})\end{array}$ & $\begin{array}{l}\text { E }_{\text {c0,Regr }} \\
\text { (MPa) }\end{array}$ & $\begin{array}{c}\Delta \\
(\%)\end{array}$ & $\begin{array}{l}\mathbf{E}_{\mathrm{c} 0, \mathrm{NBR}} \\
\text { (MPa) }\end{array}$ & $\begin{array}{l}\mathbf{E}_{\mathrm{c} 0, \mathrm{Regr}} \\
(\mathrm{MPa})\end{array}$ & $\begin{array}{c}\Delta \\
(\%)\end{array}$ \\
\hline PIN-01 & 10168 & 10117 & $-0,5$ & 8878 & 8849 & 0,3 \\
\hline PIN-02 & 14230 & 14168 & $-0,4$ & 15443 & 15505 & 0,4 \\
\hline PIN-03 & 8198 & 8203 & 0,1 & 6494 & 6462 & $-0,5$ \\
\hline PIN-04 & 6642 & 6639 & 0,0 & 6887 & 6788 & $-1,4$ \\
\hline PIN-05 & 6123 & 6145 & 0,4 & 5969 & 5935 & $-0,6$ \\
\hline PIN-06 & 14953 & 14821 & $-0,9$ & 15049 & 14143 & $-6,0$ \\
\hline PIN-07 & 10383 & 10292 & $-0,9$ & 10402 & 9995 & $-3,9$ \\
\hline PIN-08 & 7357 & 7345 & $-0,2$ & 8598 & 8506 & $-1,1$ \\
\hline PIN-09 & 16349 & 15538 & $-5,0$ & 15746 & 14434 & $-8,3$ \\
\hline PIN-10 & 11365 & 11313 & $-0,5$ & 8969 & 8928 & $-0,5$ \\
\hline PIN-11 & 10052 & 9880 & $-1,7$ & 8136 & 7983 & $-1,9$ \\
\hline PIN-12 & 11045 & 11064 & 0,2 & 12104 & 11767 & $-2,8$ \\
\hline
\end{tabular}

TABELA 92 - Valores individuais de rigidez à compressão paralela (amostra 01b PIN-13 a PIN-32) -correção da umidade (LOGSDON (1998))

\begin{tabular}{|c|c|c|c|c|c|c|}
\hline \multirow{3}{*}{$\mathbf{C P}$} & \multicolumn{6}{|c|}{ Correção da umidade - LOGSDON (1998) } \\
\hline & \multicolumn{3}{|c|}{ Padrão } & \multicolumn{3}{|c|}{ CCB } \\
\hline & $\begin{array}{l}\mathbf{E}_{\mathrm{c} 0, \mathrm{NBR}} \\
(\mathrm{MPa})\end{array}$ & $\begin{array}{l}\mathbf{E}_{\mathrm{c} 0, \mathrm{Regr}} \\
(\mathrm{MPa})\end{array}$ & $\begin{array}{c}\Delta \\
(\%)\end{array}$ & $\begin{array}{l}\mathbf{E}_{\mathrm{c} 0, \mathrm{NBR}} \\
(\mathrm{MPa})\end{array}$ & $\begin{array}{l}\mathbf{E}_{\mathrm{c} 0, \mathrm{Regr}} \\
\text { (MPa) }\end{array}$ & $\begin{array}{c}\Delta \\
(\%)\end{array}$ \\
\hline PIN-13 & 8349 & 8299 & $-0,6$ & 8812 & 8796 & $-0,2$ \\
\hline PIN-14 & 18067 & 16682 & $-7,7$ & 16152 & 16424 & 1,7 \\
\hline PIN-15 & 9991 & 9896 & $-1,0$ & 10010 & 9975 & $-0,4$ \\
\hline PIN-16 & 11153 & 11178 & 0,2 & 13156 & 13159 & 0,0 \\
\hline PIN-17 & 11064 & 11041 & $-0,2$ & 9855 & 9848 & $-0,1$ \\
\hline PIN-18 & 12095 & 11868 & $-1,9$ & 13362 & 13179 & $-1,4$ \\
\hline PIN-19 & 12805 & 12753 & $-0,4$ & 11747 & 11715 & $-0,3$ \\
\hline PIN-20 & 13129 & 13100 & $-0,2$ & 12829 & 12651 & $-1,4$ \\
\hline PIN-21 & 9744 & 9636 & $-1,1$ & 8341 & 8006 & $-4,0$ \\
\hline PIN-22 & 16046 & 15805 & $-1,5$ & 15933 & 15642 & $-1,8$ \\
\hline PIN-23 & 9455 & 9460 & 0,1 & 8857 & 8846 & $-0,9$ \\
\hline PIN-24 & 19840 & 19762 & $-0,4$ & 18647 & 18541 & $-0,6$ \\
\hline PIN-25 & 14172 & 14134 & $-0,3$ & 12344 & 12223 & $-1,0$ \\
\hline PIN-26 & 16489 & 16444 & $-0,3$ & 17866 & 17409 & $-2,6$ \\
\hline PIN-27 & 7548 & 7367 & $-2,4$ & 9422 & 9200 & $-2,4$ \\
\hline PIN-28 & 12793 & 12313 & $-3,8$ & 12200 & 12293 & 0,8 \\
\hline PIN-29 & 8276 & 7999 & $-3,4$ & 8377 & 8352 & $-0,3$ \\
\hline PIN-30 & 13357 & 13303 & $-0,4$ & 13666 & 13511 & $-1,1$ \\
\hline PIN-31 & 8498 & 8487 & $-0,1$ & 10210 & 9803 & $-4,0$ \\
\hline PIN-32 & 9063 & 9045 & $-0,2$ & 8027 & 7967 & $-0,8$ \\
\hline
\end{tabular}


Nesta espécie expressou-se o módulo de elasticidade longitudinal através da média aritmética e do coeficiente de variação. Tais valores estão contidos nas Tabelas 93 (referentes às Tabelas 87, 88 e 89) e 94 (referentes às Tabelas 90, 91 e 92).

TABELA 93 - Parâmetro estatístico referente a rigidez à compressão paralela correção da umidade (NBR7190/97)

\begin{tabular}{|c|c|c|c|c|c|c|c|c|c|c|c|}
\hline \multicolumn{12}{|c|}{ Método de correção da umidade - NBR 7190/97 } \\
\hline \multicolumn{4}{|c|}{ Amostra 01 (PIN01-PIN32) } & \multicolumn{4}{|c|}{ Amostra 01a (PIN01-PIN12) } & \multicolumn{4}{|c|}{ Amostra 01b (PIN13-PIN32) } \\
\hline \multicolumn{2}{|c|}{ Padrão } & \multicolumn{2}{|c|}{ CCA } & \multicolumn{2}{|c|}{ Padrão } & \multicolumn{2}{|c|}{ CCB } & \multicolumn{2}{|c|}{ Padrão } & \multicolumn{2}{|c|}{ CCB } \\
\hline $\begin{array}{c}\mathbf{E}_{\mathrm{c} 0, \mathrm{~m}} \\
(\mathrm{MPa})\end{array}$ & $\begin{array}{l}\text { CV } \\
(\%)\end{array}$ & $\begin{array}{c}\mathbf{E}_{\mathrm{c} 0, \mathrm{~m}} \\
(\mathrm{MPa})\end{array}$ & $\begin{array}{l}\text { CV } \\
(\%)\end{array}$ & $\begin{array}{c}\mathbf{E}_{\mathbf{c 0 , m}} \\
(\mathrm{MPa})\end{array}$ & $\begin{array}{l}\text { CV } \\
(\%)\end{array}$ & $\begin{array}{c}\mathbf{E}_{\mathrm{c} 0, \mathrm{~m}} \\
(\mathrm{MPa})\end{array}$ & $\begin{array}{l}C V \\
(\%)\end{array}$ & $\begin{array}{c}\mathbf{E}_{\mathrm{c} 0, \mathrm{~m}} \\
(\mathrm{MPa})\end{array}$ & $\begin{array}{l}\text { CV } \\
(\%)\end{array}$ & $\begin{array}{c}\mathbf{E}_{\mathrm{c} 0, \mathrm{~m}} \\
(\mathrm{MPa})\end{array}$ & $\begin{array}{l}\text { CV } \\
(\%)\end{array}$ \\
\hline 11240 & 28,8 & 11172 & 25,8 & 10377 & 30,1 & 10046 & 33,0 & 11758 & 27,8 & 11850 & 26,2 \\
\hline
\end{tabular}

TABELA 94 - Parâmetro estatístico referente a rigidez à compressão paralelacorreção da umidade (LOGSDON (1998))

\begin{tabular}{|c|c|c|c|c|c|c|c|c|c|c|c|}
\hline \multicolumn{12}{|c|}{ Método de correção da umidade - LOGSDON (1998) } \\
\hline \multicolumn{4}{|c|}{ Amostra 01 (PIN01-PIN32) } & \multicolumn{4}{|c|}{ Amostra 01a (PIN01-PIN12) } & \multicolumn{4}{|c|}{ Amostra 01b (PIN13-PIN32) } \\
\hline \multicolumn{2}{|c|}{ Padrão } & \multicolumn{2}{|c|}{ CCA } & \multicolumn{2}{|c|}{ Padrão } & \multicolumn{2}{|c|}{$\mathrm{CCB}$} & \multicolumn{2}{|c|}{ Padrão } & \multicolumn{2}{|c|}{$\mathrm{CCB}$} \\
\hline $\begin{array}{c}\mathbf{E}_{\mathrm{c} 0, \mathrm{~m}} \\
(\mathrm{MPa})\end{array}$ & $\begin{array}{l}\text { CV } \\
(\%)\end{array}$ & $\begin{array}{c}\mathbf{E}_{\mathrm{c} 0, \mathrm{~m}} \\
(\mathrm{MPa})\end{array}$ & $\begin{array}{l}\text { CV } \\
(\%)\end{array}$ & $\begin{array}{c}\mathbf{E}_{\mathrm{c} 0, \mathrm{~m}} \\
(\mathrm{MPa})\end{array}$ & $\begin{array}{l}\text { CV } \\
(\%)\end{array}$ & $\begin{array}{c}\mathbf{E}_{\mathrm{c} 0, \mathrm{~m}} \\
(\mathrm{MPa})\end{array}$ & $\begin{array}{l}\text { CV } \\
(\%)\end{array}$ & $\begin{array}{c}\mathbf{E}_{\mathrm{c} 0, \mathrm{~m}} \\
(\mathrm{MPa})\end{array}$ & $\begin{array}{l}\text { CV } \\
(\%)\end{array}$ & $\begin{array}{c}\mathbf{E}_{\mathrm{c} 0, \mathrm{~m}} \\
(\mathrm{MPa})\end{array}$ & $\begin{array}{l}\text { CV } \\
(\%)\end{array}$ \\
\hline 11378 & 29,1 & 11333 & 25,9 & 10460 & 30,0 & 9941 & 33,0 & 11929 & 28,2 & 11877 & 27,1 \\
\hline
\end{tabular}

Das Tabelas 93 e 94, verificou-se que, entre os CP's naturais e preservados, a diferença entre os valores dos coeficientes de variação das amostras 01 e 01 a foi de aproximadamente $3,0 \%$. Para a amostra $01 \mathrm{~b}$, tal diferença não atingiu 2,0\%. Com base nestes valores, é possível aceitar que a anisotropia do material não influenciou de forma relevante nos resultados obtidos para a rigidez.

Em virtude da semelhança dos módulos de elasticidade longitudinal " $\mathrm{E}_{\mathrm{c} 0, \mathrm{NBR}}$ " e " $\mathrm{E}_{\mathrm{c} 0, \text { Regr }}$ " apresentados nas amostras $01,01 \mathrm{a}$ e 01b, utilizou-se o Teste de Dados Pareados (Pairing) para mostrar a possível equivalência estatística dos mesmos.

Para os conjuntos de dados que compõem a amostra 01 e, considerando a correção da umidade segundo as recomendações da NBR 7190/97 e a proposta de LOGSDON (1998), foram obtidos, respectivamente, os seguintes intervalos de confiança da média para os CP's naturais: $46,8 \leq \mu_{x} \leq 243,2$ e $46,8 \leq \mu_{x} \leq 247,6$. Pode-se verificar que tais intervalos não contém o valor zero e, consequentemente, os citados conjuntos não podem ser considerados estatisticamente equivalentes. $\mathrm{O}$ mesmo foi observado para os CP's preservados com CCA, isto é, os intervalos de 
confiança obtidos foram de $36,2 \leq \mu_{x} \leq 212,4$ e $36,4 \leq \mu_{x} \leq 214,2$, considerando a correção através da NBR 7190/97 e LOGSDON (1998), respectivamente.

De acordo com os resultados apresentados para a amostra $01 \mathrm{a}$, submetidos à correção da umidade prescrita na NBR 7190/97, verificou-se os seguintes resultados: CP's preservados com CCB $\left(9,3 \leq \mu_{x} \leq 550,2\right)$; CP's não preservados $\left(-33,1 \leq \mu_{x} \leq 256,5\right)$. Para a correção da umidade proposta por LOGSDON (1998), os CP's preservados com CCB obtiveram o intervalo de confiança igual a $\left(10,2 \leq \mu_{x} \leq 547,9\right)$, enquanto para os CP's não preservados foi de $\left(-33,8 \leq \mu_{x} \leq 256,9\right)$. Conforme os intervalos mostrados acima, os conjuntos referentes aos CP's naturais são estatisticamente equivalentes, mas, o mesmo não pode ser dito aos dados relativos aos CP's preservados com CCB.

Pelo mesmo motivo, a amostra $01 \mathrm{~b}$, através das recomendações prescritas na NBR 7190/97 para a correção da umidade, determinou-se os intervalos de confiança mostrado abaixo: CP's não preservados $\left(23,9 \leq \mu_{x} \leq 306,1\right)$ e CP's preservados com CCB $\left(36,3 \leq \mu_{x} \leq 194,8\right)$. Segundo LOGSDON (1998), os intervalos de confiança foram os seguintes: CP's não preservados $\left(23,6 \leq \mu_{x} \leq 313,7\right)$ e CP's preservados com CCB $\left(34,1 \leq \mu_{x} \leq 194,2\right)$. De acordo com o exposto, verificou-se que os conjuntos de dados da amostra $01 \mathrm{~b}$, referentes aos CP's naturais e preservados com $\mathrm{CCB}$, não podem ser considerados estatisticamente equivalentes.

Além das discussões já apresentadas, é essencial e conveniente relacionar valores das propriedades de resistência e de rigidez entre os CP's naturais e preservados das amostras $01,01 \mathrm{a}$ e $01 \mathrm{~b}$.

A partir dos resultados apresentados nas Tabelas 75 e 87 (referente à correção da umidade através das prescrições da NBR 7190/97) e nas Tabelas 81 e 90 (referente à correção da umidade através da proposta de LOGSDON - 1998), obtevese a Tabela 95, cujos valores representam os quocientes entre as propriedades dos CP's preservados com CCA e naturais.

TABELA 95 - Relação da resistência e da rigidez entre os CP's preservados e os naturais - amostra 01

\begin{tabular}{c|c|c|c|c|c|c}
\hline \multirow{2}{*}{$\mathbf{C P}$} & \multicolumn{3}{|c|}{ NBR 7190/97 } & \multicolumn{3}{c}{ LOGSDON (1998) } \\
\cline { 2 - 7 } & $\left(\mathbf{f}_{\mathbf{c} 0, \mathbf{C C A}} / \mathbf{f}_{\mathbf{c} 0, \mathrm{p}}\right)$ & $\left(\mathbf{f}_{\mathbf{v} 0, \mathbf{C C A}} / \mathbf{f}_{\mathbf{v} 0, \mathbf{p}}\right)$ & $\left(\mathbf{E}_{\mathbf{c 0}, \mathbf{C C A}} / \mathbf{E}_{\mathbf{c} 0, \mathbf{p}}\right)_{\mathbf{R e g r}}$ & $\left(\mathbf{f}_{\mathbf{c} 0, \mathbf{C C A}} / \mathbf{f}_{\mathbf{c} 0, \mathrm{p}}\right)$ & $\left(\mathbf{f}_{\mathbf{v} 0, \mathbf{C C A}} / \mathbf{f}_{\mathbf{v} 0, \mathrm{p}}\right)$ & $\left(\mathbf{E}_{\mathbf{c} 0, \mathbf{C C A}} / \mathbf{E}_{\mathbf{c} 0, \mathbf{p}}\right)_{\mathbf{R e g r}}$ \\
\hline PIN-01 & 1,10 & 1,13 & 0,89 & 1,10 & 1,13 & 0,89
\end{tabular}




\begin{tabular}{l|l|l|l|l|l|l} 
PIN-02 & 1,23 & 0,85 & 1,08 & 1,21 & 0,86 & 1,07 \\
PIN-03 & 1,21 & 1,37 & 1,10 & 1,21 & 1,36 & 1,10 \\
PIN-04 & 1,24 & 1,29 & 1,07 & 1,24 & 1,30 & 1,07 \\
PIN-05 & 1,13 & 0,92 & 0,99 & 1,12 & 0,93 & 0,98 \\
PIN-06 & 1,12 & 0,92 & 0,98 & 1,11 & 0,92 & 0,97 \\
PIN-07 & 1,18 & 1,13 & 1,16 & 1,17 & 1,15 & 1,15 \\
PIN-08 & 1,26 & 0,87 & 1,31 & 1,25 & 0,88 & 1,31 \\
PIN-09 & 1,22 & 0,98 & 0,97 & 1,22 & 0,98 & 0,97 \\
PIN-10 & 1,18 & 1,16 & 0,86 & 1,17 & 1,17 & 0,86 \\
PIN-11 & $* * *$ & $* * *$ & $* * *$ & $* * *$ & $* * *$ & $* * *$ \\
PIN-12 & 1,18 & 1,16 & 1,21 & 1,19 & 1,17 & 1,21 \\
PIN-13 & 1,16 & 1,17 & 1,09 & 1,16 & 1,18 & 1,09 \\
PIN-14 & 1,10 & 1,05 & 1,02 & 1,08 & 1,07 & 1,00 \\
PIN-15 & 1,27 & 1,18 & 0,92 & 1,26 & 1,19 & 0,92 \\
PIN-16 & 1,07 & 1,28 & 1,11 & 1,07 & 1,28 & 1,11 \\
PIN-17 & 1,15 & 1,29 & 0,93 & 1,15 & 1,29 & 0,93 \\
PIN-18 & 1,10 & 1,09 & 0,95 & 1,10 & 1,09 & 0,95 \\
PIN-19 & 1,19 & 1,05 & 1,03 & 1,19 & 1,05 & 1,02 \\
PIN-20 & 1,20 & 0,87 & 0,91 & 1,19 & 0,87 & 0,90 \\
PIN-21 & 1,16 & 1,00 & 0,91 & 1,16 & 1,00 & 0,91 \\
PIN-22 & 1,25 & 1,01 & 0,93 & 1,24 & 1,02 & 0,93 \\
PIN-23 & 1,22 & 1,07 & 0,98 & 1,22 & 1,07 & 0,98 \\
PIN-24 & 1,15 & 0,75 & 0,87 & 1,15 & 0,75 & 0,87 \\
PIN-25 & 1,10 & 1,00 & 0,90 & 1,10 & 1,01 & 0,91 \\
PIN-26 & 1,25 & 0,96 & 0,95 & 1,24 & 0,97 & 0,95 \\
PIN-27 & 1,18 & 0,90 & 1,22 & 1,17 & 0,90 & 1,21 \\
PIN-28 & 1,09 & 0,82 & 1,06 & 1,09 & 0,83 & 1,05 \\
PIN-29 & 1,12 & 0,92 & 1,06 & 1,12 & 0,92 & 1,05 \\
PIN-30 & 1,12 & 0,75 & 0,90 & 1,11 & 0,75 & 0,90 \\
PIN-31 & 1,17 & 1,16 & 1,01 & 1,17 & 1,16 & 1,01 \\
PIN-32 & 1,09 & 1,17 & 0,94 & 1,09 & 1,17 & 0,94 \\
\hline & & & & & \\
\hline
\end{tabular}

Das Tabelas 76 e 88 (referente à correção da umidade através das prescrições da NBR 7190/97) e das Tabelas 82 e 91 (referente à correção da umidade através da proposta de LOGSDON - 1998), foram obtidas as Tabelas 96 e 97, respectivamente. Tais valores representam, para a amostra $01 \mathrm{a}$, os quocientes entre as propriedades dos CP's preservados e naturais.

TABELA 96 - Relação da resistência e da rigidez entre os CP's preservados e os naturais - amostra 01a (correção da umidade - NBR 7190/97)

\begin{tabular}{|c|c|c|c|c|c|}
\hline \multirow{2}{*}{$\mathbf{C P}$} & \multicolumn{5}{|c|}{ NBR 7190/97 } \\
\hline & $\left(\mathbf{f}_{\mathrm{c} 0, \mathrm{CCB}} / \mathbf{f}_{\mathrm{c} 0, \mathrm{p}}\right)$ & $\left(\mathbf{f}_{\mathrm{v} 0, \mathrm{CCB}} / \mathbf{f}_{\mathrm{v} 0, \mathrm{p}}\right)$ & $\left(\mathbf{f}_{\mathrm{t} 0, \mathrm{CCB}} / \mathbf{f}_{\mathrm{t} 0, \mathrm{p}}\right)$ & $\left(\mathbf{f}_{\mathrm{t} 0, \mathrm{CCA}} / \mathbf{f}_{\mathrm{t} 0, \mathrm{p}}\right)$ & $\left(\mathbf{E}_{\mathrm{c} 0, \mathrm{CCB}} / \mathbf{E}_{\mathrm{c} 0, \mathrm{p}}\right)_{\mathrm{Regr}}$ \\
\hline PIN-01 & 1,60 & 1,16 & 0,85 & 0,95 & 0,89 \\
\hline PIN-02 & 1,62 & 0,95 & 1,00 & 0,97 & 1,12 \\
\hline PIN-03 & 1,55 & 1,10 & 1,09 & 0,85 & 0,80 \\
\hline PIN-04 & 1,58 & 1,25 & 1,05 & 1,01 & 1,04 \\
\hline PIN-05 & 1,56 & 1,03 & 0,92 & 1,01 & 0,99 \\
\hline PIN-06 & 1,60 & 0,76 & 1,09 & 1,05 & 0,97 \\
\hline PIN-07 & 1,52 & 1,24 & 1,04 & 1,07 & 0,99 \\
\hline PIN-08 & 1,65 & 1,00 & 1,05 & 0,95 & 1,18 \\
\hline PIN-09 & 1,49 & 0,94 & 0,94 & 0,99 & 0,94 \\
\hline PIN-10 & 1,47 & 0,96 & $* * *$ & $* * *$ & 0,81 \\
\hline PIN-11 & 1,44 & 0,87 & 0,91 & 0,94 & 0,83 \\
\hline PIN-12 & 1,48 & 1,04 & 1,01 & 0,99 & 1,08 \\
\hline
\end{tabular}


TABELA 97 - Relação da resistência e da rigidez entre os CP's preservados e os naturais - amostra 01a (correção da umidade - LOGSDON (1998))

\begin{tabular}{|c|c|c|c|c|c|}
\hline \multirow{2}{*}{$\mathbf{C P}$} & \multicolumn{5}{|c|}{ LOGSDON (1998) } \\
\hline & $\left(\mathbf{f}_{\mathrm{c} 0, \mathrm{CCB}} / \mathbf{f}_{\mathrm{c} 0, \mathrm{p}}\right)$ & $\left(\mathbf{f}_{\mathrm{v} 0, \mathrm{CCB}} / \mathbf{f}_{\mathrm{v} 0, \mathrm{p}}\right)$ & $\left(\mathbf{f}_{\mathrm{t} 0, \mathrm{CCB}} / \mathbf{f}_{\mathrm{t} 0, \mathrm{p}}\right)$ & $\left(\mathbf{f}_{\mathbf{t} 0, \mathrm{CCA}} / \mathbf{f}_{\mathrm{t} 0, \mathrm{p}}\right)$ & $\left(\mathbf{E}_{\mathrm{c} 0, \mathrm{CCB}} / \mathbf{E}_{\mathrm{c} 0, \mathrm{p}}\right)_{\mathrm{Regr}}$ \\
\hline PIN-01 & 1,58 & 1,18 & 0,85 & 0,94 & 0,87 \\
\hline PIN-02 & 1,58 & 0,96 & 1,00 & 0,96 & 1,09 \\
\hline PIN-03 & 1,52 & 1,12 & 1,09 & 0,85 & 0,79 \\
\hline PIN-04 & 1,55 & 1,27 & 1,05 & 0,99 & 1,02 \\
\hline PIN-05 & 1,53 & 1,05 & 0,92 & 1,01 & 0,97 \\
\hline PIN-06 & 1,57 & 0,77 & 1,09 & 1,04 & 0,95 \\
\hline PIN-07 & 1,49 & 1,27 & 1,03 & 1,05 & 0,97 \\
\hline PIN-08 & 1,62 & 1,01 & 1,04 & 0,95 & 1,16 \\
\hline PIN-09 & 1,47 & 0,95 & 0,93 & 0,98 & 0,93 \\
\hline PIN-10 & 1,44 & 0,97 & $* * *$ & $* * *$ & 0,79 \\
\hline PIN-11 & 1,41 & 0,89 & 0,91 & 0,92 & 0,81 \\
\hline PIN-12 & 1,46 & 1,06 & 1,01 & 0,98 & 1,06 \\
\hline
\end{tabular}

Das Tabelas 77 e 89 (referente à correção da umidade através das prescrições da NBR 7190/97) e das Tabelas 83 e 92 (referente à correção da umidade através da proposta de LOGSDON - 1998), foi obtida a Tabela 98, cujos valores representam os quocientes entre as propriedades dos CP's preservados com CCB e naturais, para a amostra $01 b$.

TABELA 98 - Relação da resistência e da rigidez entre os CP's preservados e os naturais - amostra $01 \mathrm{~b}$

\begin{tabular}{|c|c|c|c|c|c|c|}
\hline \multirow{2}{*}{$\mathbf{C P}$} & \multicolumn{3}{|c|}{ NBR 7190/97 } & \multicolumn{3}{|c|}{ LOGSDON (1998) } \\
\hline & $\left(\mathbf{f}_{\mathrm{c} 0, \mathrm{CCB}} / \mathbf{f}_{\mathrm{c} 0, \mathrm{p}}\right)$ & $\left(\mathbf{f}_{\mathrm{v} 0, \mathrm{CCB}} / \mathbf{f}_{\mathrm{v} 0, \mathrm{p}}\right)$ & $\left(\mathbf{E}_{\mathrm{c} 0, \mathrm{CCB}} / \mathbf{E}_{\mathrm{c} 0, \mathrm{p}}\right)_{\mathrm{Regr}}$ & $\left(\mathbf{f}_{\mathrm{c} 0, \mathrm{CCB}} / \mathbf{f}_{\mathrm{c} 0, \mathrm{p}}\right)$ & $\left(\mathbf{f}_{\mathrm{v} 0, \mathrm{CCB}} / \mathbf{f}_{\mathrm{v} 0, \mathrm{p}}\right)$ & $\left(\mathbf{E}_{\mathrm{c} 0, \mathrm{CCB}} / \mathbf{E}_{\mathrm{c} 0, \mathrm{p}}\right)_{\mathrm{Regr}}$ \\
\hline PIN-13 & 1,24 & 0,97 & 1,06 & 1,26 & 0,95 & 1,06 \\
\hline PIN-14 & 1,24 & 0,78 & 1,01 & 1,21 & 0,76 & 0,98 \\
\hline PIN-15 & 1,11 & 0,97 & 1,00 & 1,11 & 0,94 & 1,01 \\
\hline PIN-16 & 1,05 & 0,87 & 1,16 & 1,06 & 0,82 & 1,18 \\
\hline PIN-17 & 1,13 & 0,96 & 0,88 & 1,14 & 0,91 & 0,89 \\
\hline PIN-18 & 1,06 & 1,02 & 1,10 & 1,07 & 1,01 & 1,11 \\
\hline PIN-19 & 1,14 & 0,82 & 0,91 & 1,15 & 0,80 & 0,92 \\
\hline PIN-20 & 1,20 & 1,21 & 0,97 & 1,20 & 1,18 & 0,97 \\
\hline PIN-21 & 1,17 & 1,03 & 0,83 & 1,17 & 0,98 & 0,83 \\
\hline PIN-22 & 1,20 & 0,90 & 0,99 & 1,20 & 0,86 & 0,99 \\
\hline PIN-23 & 1,24 & 0,77 & 0,94 & 1,24 & 0,75 & 0,94 \\
\hline PIN-24 & 1,14 & 0,89 & 0,94 & 1,14 & 0,87 & 0,94 \\
\hline PIN-25 & 1,13 & 0,95 & 0,86 & 1,13 & 0,92 & 0,86 \\
\hline PIN-26 & 1,26 & 0,98 & 1,06 & 1,25 & 0,95 & 1,06 \\
\hline PIN-27 & 1,29 & 0,87 & 1,24 & 1,30 & 0,85 & 1,25 \\
\hline PIN-28 & 1,13 & 1,02 & 1,00 & 1,14 & 0,98 & 1,00 \\
\hline PIN-29 & 1,13 & $* * *$ & 1,04 & 1,13 & $* * *$ & 1,04 \\
\hline PIN-30 & 1,22 & 1,06 & 1,02 & 1,22 & 1,03 & 1,02 \\
\hline PIN-31 & 1,27 & 1,10 & 1,16 & 1,27 & 1,07 & 1,15 \\
\hline PIN-32 & 1,13 & 1,25 & 0,88 & 1,14 & 1,18 & 0,88 \\
\hline
\end{tabular}

De modo preliminar, a validade dos resultados da amostra 01 (Tabela 95) pode ser comprovada através dos dados estatísticos apresentados na Tabela 99. 
TABELA 99 - Parâmetros estatísticos da relação da resistência e da rigidez entre os CP's preservado (CCA) e os naturais (sem preservação) - amostra 01

\begin{tabular}{|c|c|c|c|c|c|c|c|c|c|c|c|}
\hline \multicolumn{6}{|c|}{ NBR 7190/97 } & \multicolumn{6}{|c|}{ LOGSDON (1998) } \\
\hline \multicolumn{2}{|c|}{$\left(\mathbf{f}_{\mathrm{c} 0, \mathrm{CCA}} / \mathbf{f}_{\mathrm{c} 0, \mathrm{p}}\right)$} & \multicolumn{2}{|c|}{$\left(\mathbf{f}_{\mathrm{v} 0, \mathrm{CCA}} / \mathbf{f}_{\mathrm{v} 0, \mathrm{p}}\right)$} & \multicolumn{2}{|c|}{$\begin{array}{c}\left(\mathbf{E}_{\mathrm{c} 0, \mathrm{CCA}} / \mathbf{E}_{\mathrm{c} 0}\right. \\
\mathrm{p})_{\text {Regr }}\end{array}$} & \multicolumn{2}{|c|}{ 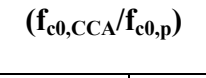 } & \multicolumn{2}{|c|}{$\left(\mathbf{f}_{\mathrm{v} 0, \mathrm{CCA}} / \mathbf{f}_{\mathrm{v} 0, \mathrm{p}}\right)$} & \multicolumn{2}{|c|}{$\begin{array}{c}\left(\mathbf{E}_{\mathrm{c} 0, \mathrm{CCA}} / \mathbf{E}_{\mathrm{c} 0},\right. \\
\left.{ }_{\mathrm{p}}\right)_{\mathrm{Regr}}\end{array}$} \\
\hline Média & $\begin{array}{l}\text { CV } \\
(\%)\end{array}$ & Média & $\begin{array}{l}\text { CV } \\
(\%)\end{array}$ & Média & $\begin{array}{l}\text { CV } \\
(\%)\end{array}$ & Média & $\begin{array}{l}\text { CV } \\
(\%)\end{array}$ & Média & $\begin{array}{l}\mathrm{CV} \\
(\%)\end{array}$ & Média & $\begin{array}{l}\text { CV } \\
(\%)\end{array}$ \\
\hline 1,17 & 5,1 & 1,04 & 15,6 & 1,01 & 10,9 & 1,16 & 5,2 & 1,05 & 15,5 & 1,01 & 10,9 \\
\hline
\end{tabular}

Da tabela acima, constatou-se que, em ambas as formas de correção de umidade, as médias das relações das resistências e da rigidez se mantiveram praticamente inalteradas. Além disto, os valores dos coeficientes de variação foram relativamente baixos, confirmando a pouca dispersão em relação aos valores médios.

Baseado na correção da umidade recomendada pela NBR 7190/97, os dados da tabela acima referentes à compressão paralela às fibras mostrou um aumento médio de $17 \%$ da resistência dos CP's preservados em relação aos naturais, para um coeficiente de variação em torno de 5\%. Para a rigidez, o acréscimo foi de $1 \%$ porcento, com um coeficiente de variação em torno de 11\%. Para a correção proposta por LOGSDON (1998), tanto a resistência quanto a rigidez se equivalem aos valores anteriores.

Analisando os resultados do cisalhamento paralelo, observou-se um acréscimo da resistência dos CP's preservados em torno de 4\%, enquanto o coeficiente de variação obtido de aproximadamente $15,5 \%$.

A comprovação da confiabilidade dos valores apresentados na Tabela 99 será dada através do Teste de Dados Pareados.

Conforme os dados apresentados na Tabela 75 (CP's tratados com CCA e naturais com umidade corrigida através da recomendação da NBR 7190/97), verificou-se que os conjuntos de dados referentes às resistências à compressão e ao cisalhamento paralelo, apresentaram os seguintes intervalos de confiança da média, respectivamente: $\left(5,7 \leq \mu_{x} \leq 7,3\right)$ e $\left(-0,3 \leq \mu_{x} \leq 0,9\right)$. Portanto, a respeito dos conjuntos de dados, concluí-se:

*CP's submetidos aos ensaios de compressão paralela (resistência): não podem ser considerados estatisticamente equivalentes;

*CP's submetidos aos ensaios de cisalhamento paralelo (resistência): podem ser considerados estatisticamente equivalentes. 
Do resultado observado para a propriedade de resistência à compressão paralela às fibras, torna-se necessária a adoção de um fator que considere a influência do produto preservativo e do processo de tratamento. Este fator poderá ser igual ao valor médio explicitado na Tabela 99, ou seja, 1,17. Entretanto, referente a equivalência estatística da resistência ao cisalhamento paralelo, desconsidera a influência do produto preservativo e do processo de tratamento. Portanto, sugere-se um fator igual a 1,0 .

Da Tabela 87 (umidade corrigida através da recomendação da NBR 7190/97), os dados de rigidez à compressão paralela dos CP's tratados com CCA e naturais são descritos através do seguinte intervalo de confiança da média, $\left(-371,4 \leq \mu_{x} \leq 473,6\right)$. Desta forma, verifica-se que os conjuntos de dados em questão são estatisticamente equivalentes. Da mesma maneira, considera-se que a influência do produto preservativo e do processo de tratamento no módulo de elasticidade da madeira não seja relevante. Então, sugere-se fator igual a 1,0.

Conforme a análise realizada para os conjuntos de dados contidos nas Tabelas 81 e 90, relativos à correção da umidade conforme a proposta de LOGSDON (1998), verificaram-se os resultados a seguir:

*CP's submetidos aos ensaios de compressão paralela (resistência): não podem ser considerados estatisticamente equivalentes (fator sugerido: 1,16);

*CP's submetidos aos ensaios de cisalhamento paralelo (resistência): podem ser considerados estatisticamente equivalentes (fator sugerido: 1,00);

*CP's submetidos aos ensaios de compressão paralela (rigidez): podem ser considerados estatisticamente equivalentes (fator sugerido: 1,00).

Resumidamente, a Tabela 100 apresenta os valores propostos para serem adotados como fatores que levem em consideração o efeito do produto e do processo preservativo nas propriedades mecânicas da madeira.

TABELA 100 - Fator $\mathrm{K}$ - efeito do preservativo e do processo de tratamento nas propriedades mecânicas da madeira - (amostra 01)

\begin{tabular}{c|c|c|c|c|c}
\hline \multicolumn{3}{|c|}{ NBR 7190/97 } & \multicolumn{3}{c}{ LOGSDON (1998) } \\
\hline$\left(\mathbf{f}_{\mathrm{c} 0, \mathrm{CCA}} / \mathbf{f}_{\mathrm{c} 0, \mathrm{p}}\right)$ & $\left(\mathbf{f}_{\left.\mathrm{v} 0, \mathrm{CCA} / \mathbf{f}_{\mathrm{v} 0, \mathrm{p}}\right)}\left(\mathbf{E}_{\mathrm{c} 0, \mathrm{CCA}} / \mathbf{E}_{\mathrm{c} 0, \mathrm{p}}\right)_{\mathrm{Regr}}\right.$ & $\left(\mathbf{f}_{\left.\mathrm{c} 0, \mathrm{CCA} / \mathbf{f}_{\mathrm{c} 0, \mathrm{p}}\right)}\right.$ & $\left(\mathbf{f}_{\mathrm{v} 0, \mathrm{CCA}} / \mathbf{f}_{\mathrm{v} 0, \mathrm{p}}\right)$ & $\left(\mathbf{E}_{\mathrm{c} 0, \mathrm{CCA}} / \mathbf{E}_{\mathrm{c} 0, \mathrm{p}}\right)_{\mathrm{Regr}}$ \\
\hline 1,17 & 1,00 & 1,00 & 1,16 & 1,00 & 1,00 \\
\hline
\end{tabular}

Os dados contidos nas Tabelas 96 e 97, referentes à amostra 01a, estão na Tabela 101, representados através da média aritmética e do coeficiente de variação. 
TABELA 101 - Parâmetros estatísticos da relação da resistência e da rigidez entre os CP's preservado e naturais (sem preservação) - amostra 01a

\begin{tabular}{|c|c|c|c|c|c|c|c|c|c|}
\hline \multicolumn{10}{|c|}{ NBR 7190/97 } \\
\hline \multicolumn{2}{|c|}{$\left(\mathbf{f}_{\mathrm{c} 0, \mathrm{CCB}} / \mathbf{f}_{\mathrm{c} 0, \mathrm{p}}\right)$} & \multicolumn{2}{|c|}{$\left(\mathbf{f}_{\mathrm{v} 0, \mathrm{CCB}} / \mathbf{f}_{\mathrm{v} \mathbf{0}, \mathrm{p}}\right)$} & \multicolumn{2}{|c|}{$\left(\mathbf{f}_{\mathrm{t} 0, \mathrm{CCB}} / \mathbf{f}_{\mathrm{c} 0, \mathrm{p}}\right)$} & \multicolumn{2}{|c|}{$\left(\mathbf{f}_{\mathrm{t} 0, \mathrm{CCA}} / \mathbf{f}_{\mathrm{v} 0, \mathrm{p}}\right)$} & \multicolumn{2}{|c|}{$\left(\mathbf{E}_{\mathrm{c} 0, \mathrm{CCB}} / \mathbf{E}_{\mathrm{c} 0, \mathrm{p}}\right)_{\mathrm{Regr}}$} \\
\hline Média & $\begin{array}{l}\text { CV } \\
(\%)\end{array}$ & Média & $\begin{array}{l}\text { CV } \\
(\%)\end{array}$ & Média & $\begin{array}{l}\text { CV } \\
(\%)\end{array}$ & Média & $\begin{array}{l}\text { CV } \\
(\%)\end{array}$ & Média & $\begin{array}{l}\text { CV } \\
(\%)\end{array}$ \\
\hline 1,55 & 4,3 & 1,03 & 14,0 & 1,00 & 8,0 & 0,98 & 6,1 & 0,97 & 12,7 \\
\hline \multicolumn{10}{|c|}{ LOGSDON (1998) } \\
\hline \multicolumn{2}{|c|}{$\left(\mathbf{f}_{\mathbf{c} 0, \mathrm{CCB}} / \mathbf{f}_{\mathbf{c} 0, \mathrm{p}}\right)$} & \multicolumn{2}{|c|}{$\left(\mathbf{f}_{\mathrm{v} 0, \mathrm{CCB}} / \mathbf{f}_{\mathrm{v} 0, \mathrm{p}}\right)$} & \multicolumn{2}{|c|}{$\left(\mathbf{f}_{\mathbf{t} 0, \mathrm{CCB}} / \mathbf{f}_{\mathbf{c} 0, \mathrm{p}}\right)$} & \multicolumn{2}{|c|}{$\left(\mathbf{f}_{\mathbf{t} 0, \mathrm{CCA}} / \mathbf{f}_{\mathrm{v} 0, \mathrm{p}}\right)$} & \multicolumn{2}{|c|}{$\left(\mathbf{E}_{\mathrm{c} 0, \mathrm{CCB}} / \mathbf{E}_{\mathrm{c} 0, \mathrm{p}}\right)_{\mathrm{Regr}}$} \\
\hline Média & $\begin{array}{l}C V \\
(\%)\end{array}$ & Média & $\begin{array}{l}\text { CV } \\
(\%)\end{array}$ & Média & $\begin{array}{l}\text { CV } \\
(\%)\end{array}$ & Média & $\begin{array}{l}\text { CV } \\
(\%)\end{array}$ & Média & $\begin{array}{l}C V \\
(\%)\end{array}$ \\
\hline 1,52 & 4,3 & 1,04 & 14,4 & 0,99 & 8,0 & 0,97 & 5,8 & 0,95 & 12,8 \\
\hline
\end{tabular}

Conforme os resultados apresentados acima, observou-se que as médias das relações das resistências e da rigidez se mantiveram praticamente inalteradas. $\mathrm{O}$ mesmo pode ser dito a respeito dos coeficientes de variação e, além disto, os valores confirmaram a pouca dispersão em relação média.

Conforme a correção da umidade recomendada pela NBR 7190/97, os dados referentes à compressão paralela às fibras mostrou um aumento médio de 55\% para a resistência dos CP's preservados com $\mathrm{CCB}$ em relação aos naturais, para um coeficiente de variação inferior a 5\%. Para a rigidez, o decréscimo foi de $3 \%$, com um coeficiente de variação próximo de 13\%. Para a correção proposta por LOGSDON (1998), obteve-se um acréscimo médio de 52\% para a resistência, enquanto a rigidez sofreu uma redução de $5 \%$.

Analisando os resultados do cisalhamento paralelo, verificou-se um acréscimo da resistência dos CP's preservados com CCB em torno de 4\% e coeficiente de variação de aproximadamente 14\%, seja segundo as recomendações da NBR 7190/97, quanto as propostas de LOGSDON (1998).

No que diz respeito à tração paralela para os CP's preservados com CCA, independente do método de correção da umidade, os resultados foram:

*Média da resistência: redução de aproximadamente $2 \%$;

*Coeficiente de variação da resistência: em torno de 6\%.

Referente à tração paralela para os CP's preservados com $\mathrm{CCB}$, em ambos os método de correção da umidade, os resultados obtidos foram os seguintes:

*Média da resistência: inalterada;

*Coeficiente de variação da resistência: em torno de $8 \%$. 
A confiabilidade dos valores apresentados na Tabela 101 será comprovada através do Teste de Dados Pareados.

De acordo com o teste citado acima e a partir da Tabela 76 (CP's preservados com $\mathrm{CCB}$ e naturais, com umidade corrigida através da recomendação da NBR 7190/97), verificou-se os seguintes intervalos de confiança da média:

*CP's submetidos aos ensaios de compressão paralela (resistência): $\left(18,7 \leq \mu_{x} \leq 23,1\right)$, não podem ser considerados estatisticamente equivalentes;

*CP's submetidos aos ensaios de cisalhamento paralelo (resistência): $\left(-0,8 \leq \mu_{x} \leq 1,0\right)$, podem ser considerados estatisticamente equivalentes;

*CP's submetidos aos ensaios de tração paralela (resistência): $\left(-3,7 \leq \mu_{x} \leq 2,6\right)$, podem ser considerados estatisticamente equivalentes.

Segundo a mesma tabela (CP's preservados com CCA e naturais, com umidade corrigida através da recomendação da NBR 7190/97), constatou-se que, através do intervalo de confiança da média $\left(-3,0 \leq \mu_{x} \leq 0,8\right)$, os conjuntos submetidos aos ensaios de tração paralela (resistência) podem ser considerados estatisticamente equivalentes.

Do resultado observado para a propriedade de resistência à compressão paralela às fibras, torna-se necessária a adoção de um fator que considere a influência do produto preservativo e do processo de tratamento. Este fator poderá ser igual ao valor médio explicitado na Tabela 101, ou seja, 1,55. Entretanto, a equivalência estatística referente as resistências à tração e ao cisalhamento paralelo, considera-se que a influência do produto preservativo e do processo de tratamento não seja relevante. Assim sendo, sugere-se a aplicação de um coeficiente igual a 1,0.

Da Tabela 88 (umidade corrigida através da recomendação da NBR 7190/97), os dados de rigidez à compressão paralela dos CP's tratados com CCB e naturais são descritos através do seguinte intervalo de confiança da média, $\left(-1104,5 \leq \mu_{x} \leq 442,8\right)$. Assim sendo, verifica-se que tais conjuntos são estatisticamente equivalentes, portanto, não é necessária a consideração da influência do produto preservativo e do processo de tratamento no módulo de elasticidade da madeira. Desta forma, sugere-se fator igual a 1,0. 
Conforme a análise realizada para os conjuntos de dados contidos na Tabela 82, relativos à correção da umidade conforme a proposta de LOGSDON (1998), foi verificada que a resistência à compressão paralela às fibras não pode ser considerada estatisticamente equivalente, enquanto para a resistência à tração paralela e ao cisalhamento paralelo, pode-se verificar a equivalência estatística. Desta forma, sugerem-se fatores de correção iguais a 1,52, 1,00 e 1,00, respectivamente. Da mesma tabela, também foi observado que a resistência à tração paralela às fibras (CP's preservados com CCA) pode ser considerada estatisticamente equivalente.

Segundo a mesma maneira de correção de umidade, a Tabela 91 permite concluir que a rigidez à compressão paralela entre os CP's preservados e não preservados são estatisticamente equivalentes. Isto mostra que não é necessária a correção da citada propriedade.

A Tabela 102 apresenta resumidamente os valores propostos para serem adotados como fatores que considerem o efeito do produto e do processo preservativo nas propriedades mecânicas da madeira.

TABELA 102 - Fator K - efeito do preservativo e do processo de tratamento nas propriedades mecânicas da madeira - (amostra 01a)

\begin{tabular}{|c|c|c|c|c|}
\hline \multicolumn{5}{|c|}{ NBR 7190/97 } \\
\hline$\left(\mathbf{f}_{\mathrm{c} 0, \mathrm{CCB}} / \mathbf{f}_{\mathrm{c} 0, \mathrm{p}}\right)$ & $\left(\mathbf{f}_{\mathrm{v} 0, \mathrm{CCB}} / \mathbf{f}_{\mathrm{v} 0, \mathrm{p}}\right)$ & $\left(\mathbf{f}_{\mathrm{t} 0, \mathrm{CCB}} / \mathbf{f}_{\mathrm{c} 0, \mathrm{p}}\right)$ & $\left(\mathbf{f}_{\mathrm{t} 0, \mathrm{CCA}} / \mathbf{f}_{\mathrm{v} 0, \mathrm{p}}\right)$ & $\left(\mathbf{E}_{\mathrm{c} 0, \mathrm{CCB}} / \mathbf{E}_{\mathrm{c} 0, \mathrm{p}}\right)_{\mathrm{Regr}}$ \\
\hline 1,55 & 1,00 & 1,00 & 1,00 & 1,00 \\
\hline \multicolumn{5}{|c|}{ LOGSDON (1998) } \\
\hline$\left(\mathbf{f}_{\mathrm{c} 0, \mathrm{CCB}} / \mathbf{f}_{\mathrm{c} 0, \mathrm{p}}\right)$ & $\left(\mathbf{f}_{\mathrm{v} 0, \mathrm{CCB}} / \mathbf{f}_{\mathrm{v} 0, \mathrm{p}}\right)$ & $\left(\mathbf{f}_{\mathrm{t} 0, \mathrm{CCB}} / \mathbf{f}_{\mathrm{c0}, \mathrm{p}}\right)$ & $\left(\mathbf{f}_{\mathrm{t} 0, \mathrm{CCA}} / \mathbf{f}_{\mathrm{v} 0, \mathrm{p}}\right)$ & $\left(\mathrm{E}_{\mathrm{c} 0, \mathrm{CCB}} / \mathrm{E}_{\mathrm{c} 0, \mathrm{p}}\right)_{\mathrm{Regr}}$ \\
\hline 1,52 & 1,00 & 1,00 & 1,00 & 1,00 \\
\hline
\end{tabular}

Os dados referentes a amostra 01b (Tabela 98) podem ser comprovados estatisticamente através dos parâmetros apresentados na Tabela 103.

TABELA 103 - Parâmetros estatísticos da relação da resistência e da rigidez entre os CP's preservado (CCB) e os naturais (sem preservação) - amostra $01 \mathrm{~b}$

\begin{tabular}{|c|c|c|c|c|c|c|c|c|c|c|c|}
\hline \multicolumn{6}{|c|}{ NBR 7190/97 } & \multicolumn{6}{|c|}{ LOGSDON (1998) } \\
\hline \multicolumn{2}{|c|}{$\left(\mathbf{f}_{\mathbf{c} 0, \mathrm{CCB}} / \mathbf{f}_{\mathbf{c} 0, \mathrm{p}}\right)$} & \multicolumn{2}{|c|}{$\left(\mathbf{f}_{\mathrm{v} 0, \mathrm{CCB}} / \mathbf{f}_{\mathrm{v} 0, \mathrm{p}}\right)$} & \multicolumn{2}{|c|}{$\left(\mathbf{E}_{\mathrm{c} 0, \mathrm{CCB}} / \mathbf{E}_{\mathrm{c} 0, \mathrm{p}}\right)_{\operatorname{Regr}}$} & \multicolumn{2}{|c|}{$\left(\mathbf{f}_{\mathrm{c} 0, \mathrm{CCB}} / \mathbf{f}_{\mathrm{c} 0, \mathrm{p}}\right)$} & \multicolumn{2}{|c|}{$\left(\mathbf{f}_{\mathrm{v} 0, \mathrm{CCB}} / \mathbf{f}_{\mathrm{v} 0, \mathrm{p}}\right)$} & \multicolumn{2}{|c|}{$\left(\mathbf{E}_{\mathrm{c} 0, \mathrm{CCB}} / \mathbf{E}_{\mathrm{c} 0, \mathrm{p}}\right)_{\mathrm{Regr}}$} \\
\hline Média & $\begin{array}{l}\text { CV } \\
(\%)\end{array}$ & Média & CV $(\%)$ & Média & CV (\%) & Média & CV $(\%)$ & Média & CV $(\%)$ & Média & CV $(\%)$ \\
\hline 1,17 & 5,9 & 0,97 & 13,3 & 1,00 & 10,8 & 1,18 & 5,7 & 0,94 & 13,1 & 1,00 & 10,9 \\
\hline
\end{tabular}

Conforme a Tabela 103, foi possível verificar que as médias das relações da resistência e da rigidez, referente à compressão paralela às fibras, se mantiveram praticamente inalteradas, independente da forma de correção de umidade. Em contrapartida, houve uma pequena diferença entre as médias das relações das resistências ao cisalhamento paralelo às fibras. Também vale ressaltar os baixos 
valores dos coeficientes de variação, confirmando assim, a pouca dispersão dos resultados em relação aos valores médios.

Da correção da umidade recomendada pela NBR 7190/97, os dados da tabela acima referentes à compressão paralela, mostraram um aumento médio de $17 \%$ da resistência dos CP's preservados em relação aos naturais, para um coeficiente de variação inferior a $6 \%$. A média da rigidez, por sua vez, manteve-se inalterada, porém, o coeficiente de variação atingiu $10 \%$. A correção proposta por LOGSDON (1998), tanto a resistência quanto a rigidez se equivalem aos valores anteriores.

Fazendo a análise dos resultados do cisalhamento paralelo, observou-se um decréscimo da resistência dos CP's preservados em torno de 3\% e 6\%, considerando as correções de umidade segundo a NBR 7190/97 e LOGSDON (1998), respectivamente. Para ambos os casos, o coeficiente de variação obtido foi de aproximadamente $13,2 \%$.

A confiabilidade dos valores apresentados na Tabela 103 será comprovada através do Teste de Dados Pareados.

Segundo a Tabela 77 (CP's tratados com CCB e naturais com umidade corrigida através da recomendação da NBR 7190/97), verificou-se que os conjuntos de dados referentes às resistências à compressão e ao cisalhamento paralelo, apresentaram os seguintes intervalos de confiança da média, respectivamente: $\left(5,6 \leq \mu_{x} \leq 7,9\right)$ e $\left(-0,2 \leq \mu_{x} \leq 1,1\right)$. Desta forma, concluí-se que os conjuntos de dados relativos à resistência à compressão paralela não podem ser considerados estatisticamente equivalentes. Todavia, a equivalência pode ser dada aos conjuntos submetidos aos ensaios de resistência ao cisalhamento paralelo.

A partir do resultado obtido para a resistência à compressão paralela às fibras, torna-se necessária a adoção de um fator que considere a influência do produto preservativo e do processo de tratamento. Tal fator poderá ser igual ao valor médio explicitado na Tabela 103, ou seja, 1,17. Entretanto, a equivalência estatística referente a resistência ao cisalhamento paralelo, permite aceitar que não haja influência do produto preservativo e do processo de tratamento. Portanto, sugere-se a adoção de um coeficiente igual a 1,0 .

Da Tabela 89 (umidade corrigida através da recomendação da NBR 7190/97), os dados de rigidez à compressão paralela dos CP's tratados com CCB e naturais são 
descritos conforme o intervalo de confiança da média, $\left(-457,4 \leq \mu_{x} \leq 573,9\right)$. Desta forma, verifica-se que os conjuntos de dados em questão são estatisticamente equivalentes. Por este motivo, sugere-se fator igual a 1,0.

Segundo a análise realizada para os conjuntos de dados contidos na Tabela 83, relativos à correção da umidade conforme a proposta de LOGSDON (1998), foi verificada que a resistência à compressão paralela às fibras não pode ser considerada estatisticamente equivalente, enquanto para a resistência ao cisalhamento paralelo, pode-se verificar a equivalência estatística. Desta forma, sugerem-se fatores de correção iguais a 1,18 e 1,00, respectivamente.

Segundo a mesma maneira de correção de umidade, a Tabela 92 permite concluir que a rigidez à compressão paralela entre os CP's preservados e não preservados pode ser considerada estatisticamente equivalentes. Isto prova que não é necessária a correção da citada propriedade.

Resumidamente, a Tabela 104 apresenta os valores propostos para serem adotados como fatores que levem em consideração o efeito do produto e do processo preservativo nas propriedades mecânicas da madeira.

TABELA 104 - Fator K - efeito do preservativo e do processo de tratamento nas propriedades mecânicas da madeira - (amostra 01b)

\begin{tabular}{c|c|c|c|c|c}
\hline \multicolumn{3}{|c|}{ NBR 7190/97 } & \multicolumn{3}{c}{ LOGSDON (1998) } \\
\hline$\left(\mathbf{f}_{\mathrm{c} 0, \mathrm{CCB}} / \mathbf{f}_{\mathrm{c} 0, \mathrm{p}}\right)$ & $\left(\mathbf{f}_{\mathrm{v} 0, \mathrm{CCB}} / \mathbf{f}_{\mathrm{v} 0, \mathrm{p}}\right)$ & $\left(\mathbf{E}_{\mathrm{c} 0, \mathrm{CCB}} / \mathbf{E}_{\mathrm{c} 0, \mathrm{p}}\right)_{\mathrm{Regr}}$ & $\left(\mathbf{f}_{\left.\mathbf{c} 0, \mathrm{CCB} / \mathbf{f}_{\mathrm{c} 0, \mathrm{p}}\right)}\right.$ & $\left(\mathbf{f}_{\mathrm{v} 0, \mathrm{CCB}} / \mathbf{f}_{\mathrm{v} 0, \mathrm{p}}\right)$ & $\left(\mathbf{E}_{\mathrm{c} 0, \mathrm{CCB}} / \mathbf{E}_{\mathrm{c} 0, \mathrm{p}}\right)_{\mathrm{Regr}}$ \\
\hline 1,17 & 1,00 & 1,00 & 1,18 & 1,00 & 1,00 \\
\hline
\end{tabular}

\subsubsection{Relações comparativas entre resistências características}

Este item tem o intuito principal de explicitar algumas relações de resistências características, principalmente entre compressão e cisalhamento paralelo e compressão e tração paralela às fibras, tanto em CP's sem preservação, como naqueles preservados com CCA e CCB. A seguir, tais relações são apresentadas para cada espécie estudada.

\subsubsection{Espécies nativas}

\subsubsection{1a Angelim (Vatairea $s p)$}

Com correção da umidade segundo NBR 7190/97, os CP's sem preservação submetidos aos ensaios de cisalhamento paralelo e de compressão paralela, atingiram valores de resistências características iguais a $10,1 \mathrm{MPa}$ e $48,8 \mathrm{MPa}$, respectivamente. 
Desta forma, foi possível verificar um quociente de aproximadamente 0,21. De acordo com LOGSDON (1998), foram obtidos valores iguais a 9,9MPa e 50,7MPa, respectivamente, determinando uma relação em torno de 0,20.

Para os CP's preservados com CCA, também foi possível verificar os valores das resistências características ao cisalhamento e à compressão paralela, ou seja, 8,7MPa e 47,4MPa, respectivamente, segundo a correção da umidade recomendada pela NBR 7190/97. Para a correção devida a sugestão de LOGSDON (1998), os valores são: $8,4 \mathrm{MPa}$ e 49,0MPa. Com estes resultados, as relações obtidas foram iguais a 0,18 (NBR 7190/97) e 0,17 (LOGSDON (1998)).

\subsubsection{1b Ipê (Tabebuia sp)}

Conforme as recomendações da NBR 7190/97 para a correção da umidade, os CP's sem preservação submetidos aos ensaios de cisalhamento paralelo e de compressão paralela, atingiram valores de resistências características iguais a $8,5 \mathrm{MPa}$ e $81,5 \mathrm{MPa}$, respectivamente. Desta forma, foi possível verificar um quociente de aproximadamente 0,10. De acordo com LOGSDON (1998), foram obtidos valores iguais a $8,4 \mathrm{MPa}$ e $80,5 \mathrm{MPa}$, respectivamente, determinando uma relação em torno de 0,10 .

Para os CP's preservados com CCA, também foi possível verificar os valores das resistências características ao cisalhamento e à compressão paralela, ou seja, $10,3 \mathrm{MPa}$ e $80,6 \mathrm{MPa}$, respectivamente, segundo a correção da umidade recomendada pela NBR 7190/97. Para a correção devida a sugestão de LOGSDON (1998), os valores são: $9,9 \mathrm{MPa}$ e $81,2 \mathrm{MPa}$. Com estes resultados, as relações obtidas foram iguais a 0,13 (NBR 7190/97) e 0,12 (LOGSDON (1998)).

\subsubsection{1c Copaíba (Copaifera sp)}

Com correção da umidade segundo NBR 7190/97, os CP's sem preservação submetidos aos ensaios de cisalhamento paralelo e de compressão paralela, atingiram valores de resistências características iguais a 18,7MPa e 73,6MPa, respectivamente. Desta forma, foi possível verificar um quociente de aproximadamente 0,25. De acordo com LOGSDON (1998), foram obtidos valores iguais a $18,8 \mathrm{MPa}$ e $74,2 \mathrm{MPa}$, respectivamente, determinando uma relação em torno de 0,25 . 
Para os CP's preservados com CCA, também foi possível verificar os valores das resistências características ao cisalhamento e à compressão paralela, ou seja, $18,8 \mathrm{MPa}$ e 79,0MPa, respectivamente, segundo a correção da umidade recomendada pela NBR 7190/97. Para a correção devida a sugestão de LOGSDON (1998), os valores são: 19,0MPa e 78,7MPa. Com estes resultados, as relações obtidas foram iguais a 0,24 (NBR 7190/97) e 0,24 (LOGSDON (1998)).

\subsubsection{1d Jatobá (Hymenaea sp)}

Conforme as recomendações da NBR 7190/97 para a correção da umidade, os CP's sem preservação submetidos aos ensaios de cisalhamento paralelo e de compressão paralela, atingiram valores de resistências características iguais a $19,5 \mathrm{MPa}$ e $86,2 \mathrm{MPa}$, respectivamente. Desta forma, foi possível verificar um quociente de aproximadamente 0,23. De acordo com LOGSDON (1998), foram obtidos valores iguais a $19,4 \mathrm{MPa}$ e $85,1 \mathrm{MPa}$, respectivamente, determinando uma relação em torno de 0,23.

Para os CP's preservados com CCA, também foi possível verificar os valores das resistências características ao cisalhamento e à compressão paralela, ou seja, 18,3MPa e 85,9MPa, respectivamente, segundo a correção da umidade recomendada pela NBR 7190/97. Para a correção devida a sugestão de LOGSDON (1998), os valores são: 18,3MPa e 85,0MPa. Com estes resultados, as relações obtidas foram iguais a 0,21 (NBR 7190/97) e 0,21 (LOGSDON (1998)).

\subsubsection{Espécies de reflorestamento}

\subsubsection{2a Eucalipto Grandis (Eucalyptus grandis)}

Conforme as recomendações da NBR 7190/97 para a correção da umidade, os CP's sem preservação da amostra 01 submetidos aos ensaios de cisalhamento paralelo e de compressão paralela, atingiram valores de resistências características iguais a 9,7MPa e 53,7MPa, respectivamente. Desta forma, foi possível verificar um quociente de aproximadamente 0,18. De acordo com LOGSDON (1998), foram obtidos valores iguais a $9,6 \mathrm{MPa}$ e $54,0 \mathrm{MPa}$, respectivamente, determinando uma relação em torno de 0,18 .

Para os CP's preservados com CCA da amostra 01, também foi possível verificar os valores das resistências características ao cisalhamento e à compressão 
paralela, ou seja, 12,0MPa e 64,3MPa, respectivamente, segundo a correção da umidade recomendada pela NBR 7190/97. Para a correção devida a sugestão de LOGSDON (1998), os valores são: 11,9MPa e 65,5MPa. Com estes resultados, as relações obtidas foram iguais a 0,19 (NBR 7190/97) e 0,18 (LOGSDON (1998)).

Considerando os CP's sem preservação da amostra 02 , com a correção da umidade de acordo com as recomendações da NBR 7190/97, também submetidos aos ensaios de cisalhamento paralelo e de compressão paralela, atingiram valores de resistências características iguais a $11,7 \mathrm{MPa}$ e $64,1 \mathrm{MPa}$, respectivamente. Desta forma, foi possível verificar um quociente de aproximadamente 0,18 . De acordo com LOGSDON (1998), foram obtidos valores iguais a $11,4 \mathrm{MPa}$ e $66,2 \mathrm{MPa}$, respectivamente, determinando uma relação em torno de 0,17 .

Para os CP's preservados com CCA da amostra 02, também foi possível verificar os valores das resistências características ao cisalhamento e à compressão paralela, ou seja, $11,1 \mathrm{MPa}$ e $63,8 \mathrm{MPa}$, respectivamente, segundo a correção da umidade recomendada pela NBR 7190/97. Para a correção devida a sugestão de LOGSDON (1998), os valores são: 11,0MPa e 65,7MPa. Com estes resultados, as relações obtidas foram iguais a 0,17 (NBR 7190/97) e 0,17 (LOGSDON (1998)).

Para os CP's preservados com CCB da amostra 02, foi determinado os valores das resistências características ao cisalhamento e à compressão paralela, ou seja, $10,7 \mathrm{MPa}$ e $71,0 \mathrm{MPa}$, respectivamente, segundo a correção da umidade recomendada pela NBR 7190/97. Para a correção devida a sugestão de LOGSDON (1998), os valores são: 10,4MPa e 73,1MPa. Com estes resultados, as relações obtidas foram iguais a 0,15 (NBR 7190/97) e 0,14 (LOGSDON (1998)).

\subsubsection{2b Pinus Elliottii (Pinus elliottii)}

Conforme as recomendações da NBR 7190/97 para a correção da umidade, os CP's sem preservação da amostra 01 submetidos aos ensaios de cisalhamento paralelo e de compressão paralela, atingiram valores de resistências características iguais a 7,3MPa e $32,7 \mathrm{MPa}$, respectivamente. Desta forma, foi possível verificar um quociente de aproximadamente 0,22. De acordo com LOGSDON (1998), foram obtidos valores iguais a 7,2MPa e $33,2 \mathrm{MPa}$, respectivamente, determinando uma relação igual a 0,22. Para os CP's preservados com CCA da amostra 01, também foi 
possível verificar os valores das resistências características ao cisalhamento e à compressão paralela, ou seja, $8,1 \mathrm{MPa}$ e $37,5 \mathrm{MPa}$, respectivamente, segundo a correção da umidade recomendada pela NBR 7190/97. Para a correção devida a sugestão de LOGSDON (1998), os valores são: 8,0MPa e 37,4MPa. Com estes resultados, as relações obtidas foram iguais a 0,22 (NBR 7190/97) e 0,21 (LOGSDON (1998)).

Considerando os CP's sem preservação da amostra 01b, com a correção da umidade de acordo com as recomendações da NBR 7190/97, também submetidos aos ensaios de cisalhamento paralelo e de compressão paralela, atingiram valores de resistências características iguais a $7,3 \mathrm{MPa}$ e $31,4 \mathrm{MPa}$, respectivamente. Desta forma, foi possível verificar um quociente de aproximadamente 0,23. De acordo com LOGSDON (1998), foram obtidos valores iguais a 7,2MPa e $31,5 \mathrm{MPa}$, respectivamente, determinando uma relação em torno de 0,23. Para os CP's preservados com CCB da amostra 01b, também foi possível verificar os valores das resistências características ao cisalhamento e à compressão paralela, ou seja, 7,4MPa e $36,8 \mathrm{MPa}$, respectivamente, segundo a correção da umidade recomendada pela NBR 7190/97. Para a correção devida a sugestão de LOGSDON (1998), os valores são: $7,1 \mathrm{MPa}$ e $37,4 \mathrm{MPa}$. Com estes resultados, as relações obtidas foram iguais a 0,20 (NBR 7190/97) e 0,19 (LOGSDON (1998)).

Considerando os CP's sem preservação da amostra 01a, com a correção da umidade de acordo com as recomendações da NBR 7190/97, submetidos aos ensaios de cisalhamento paralelo, de tração paralela e de compressão paralela, atingiram valores de resistências características iguais a 7,9MPa, $43,7 \mathrm{MPa}$ e $32,5 \mathrm{MPa}$, respectivamente. Da relação entre os valores de compressão e tração paralela, foi possível verificar um quociente de aproximadamente 0,74. Em contrapartida, o quociente entre os valores do cisalhamento e compressão paralela foi de 0,24 . De acordo com LOGSDON (1998), foram obtidos valores iguais a 7,8MPa, 43,9MPa e $32,7 \mathrm{MPa}$, respectivamente. Para as relações entre compressão e tração paralela e cisalhamento e compressão paralela, obteve-se os seguintes valores, respectivamente, 0,74 e 0,24. Para os CP's preservados com CCB da amostra 01a, foram determinados os valores das resistências características ao cisalhamento, à tração e à compressão paralela, ou seja, 9,0MPa, 42,1MPa e 55,7Pa, respectivamente, segundo a correção 
da umidade recomendada pela NBR 7190/97. Para a correção devida a sugestão de LOGSDON (1998), os valores são: 9,1MPa, 42,1MPa e 55,1MPa. De acordo com os resultados, as relações entre cisalhamento e compressão paralela foram iguais a 0,16 (NBR 7190/97) e 0,17 (LOGSDON (1998)). Considerando os valores obtidos para a compressão e tração paralela, os quocientes foram iguais a 1,32 (NBR 7190/97) e 1,31 (LOGSDON (1998)).

Segundo a correção da umidade recomendada pela NBR 7190/97, a resistência característica à tração paralela para os CP's preservados com CCA (amostra 01a) foi igual a 41,8MPa. Para os CP's preservados com CCA, o valor da resistência característica à compressão paralela às fibras foi de $37,5 \mathrm{MPa}$. Para a correção devida a sugestão de LOGSDON (1998), os valores são: 41,4MPa e 37,4MPa. De acordo com os resultados, as relações entre compressão e tração paralela foram iguais a 0,90 (NBR 7190/97 e LOGSDON (1998)).

Portanto, na ausência de alguns parâmetros de resistência, devido a falta de determinação experimental, tais relações podem vir a contribuir na elaboração de projetos de estruturas de madeira. 


\section{CAPÍTULO 5: CONCLUSÕES}

De acordo com desenvolvimento do presente trabalho, este capítulo será apresentado em duas partes. A primeira, refere-se às conclusões específicas às espécies nativas, enquanto a segunda, enfoca as conclusões referentes às espécies de reflorestamento.

\section{a) Espécies nativas}

Os resultados apresentados no Capítulo 4, referentes às variações das propriedades mecânicas de espécies nativas, devidas ao efeito da penetração do preservativo e do processo de tratamento estão resumidos na Tabela 105.

TABELA 105 - Fatores K - valores relativos ao efeito da penetração do preservativo CCA e do processo de tratamento - espécies nativas

\begin{tabular}{|c|c|c|c|c|c|}
\hline Espécie & $\begin{array}{l}\text { Classe de resistência } \\
\text { (CP's naturais) }\end{array}$ & $\begin{array}{l}\text { Classe de resistência } \\
\text { (CP's preservados) }\end{array}$ & $\left(\mathbf{f}_{\mathrm{c} 0, \mathrm{CCA}} / \mathbf{f}_{\mathrm{c} 0, \mathrm{p}}\right)$ & $\left(\mathbf{f}_{\mathrm{v} 0, \mathrm{CCA}} / \mathbf{f}_{\mathrm{v} \mathbf{p}, \mathrm{p}}\right)$ & $\left(\mathbf{E}_{\mathrm{c} 0, \mathrm{CCA}} / \mathbf{E}_{\mathrm{c} 0, \mathrm{p}}\right)_{\mathrm{Reg}}$ \\
\hline Angelim & $\mathrm{C}-40$ & $\mathrm{C}-40$ & 1,00 & 1,00 & 1,00 \\
\hline Ipê & C-60 & C-60 & 1,00 & 0,93 & 1,00 \\
\hline Copaíba & C-60 & C-60 & 1,00 & 1,00 & 1,00 \\
\hline Jatobá & $\mathrm{C}-60$ & $\mathrm{C}-60$ & 0,94 & 1,00 & 0,94 \\
\hline
\end{tabular}

Os valores mostram que, mesmo havendo apenas penetração superficial do preservativo, o processo de preservação envolvendo a aplicação de pressão pode provocar redução nas propriedades estudadas. Na eventual opção por tratamento de espécies nativas, o emprego de processos não industriais (sem aplicação de pressão) seria uma alternativa satisfatória para não provocar modificação nas propriedades mecânicas à compressão e ao cisalhamento paralelo às fibras.

Os valores referentes às relações entre resistências características ao cisalhamento e à compressão paralela às fibras, tanto em CP's sem preservação como naqueles preservados com CCA, mostrados na Tabela 106, foram determinados de acordo com as seguintes expressões: 


$$
* \frac{f_{v 0, k, p}}{f_{c 0, k, p}}=K_{p} ; * \frac{f_{v 0, k, C C A}}{f_{c 0, k, C C A}}=K_{C C A}
$$

TABELA 106 - Valores referentes às relações entre resistências características ao cisalhamento e à compressão paralela às fibras - espécies nativas

\begin{tabular}{c|c|c|c|c|c}
\hline \multirow{2}{*}{ Espécie } & \multicolumn{3}{|c|}{ Valores determinados } & $\begin{array}{c}\text { Valor } \\
\text { recomendado } \\
\end{array}$ & \multicolumn{2}{|c|}{$\begin{array}{c}\text { Correção da umidade } \\
\text { (NBR 7190/97) }\end{array}$} & \multicolumn{2}{c}{$\begin{array}{c}\text { Correção da umidade } \\
\text { (LOGSDON (1998)) }\end{array}$} & \begin{tabular}{c} 
(NBR 7190/97) \\
\cline { 2 - 5 }
\end{tabular} & $K_{p}^{N B R}$ & $K_{C C A}^{N B R}$ & $K_{p}^{L O G S D O N}$ & $K_{C C A}^{L O G S O N}$ & $K$ \\
\hline Angelim & 0,21 & 0,18 & 0,20 & 0,17 & 0,12 \\
Ipê & 0,10 & 0,13 & 0,10 & 0,12 & 0,12 \\
Copaíba & 0,25 & 0,24 & 0,25 & 0,24 & 0,12 \\
Jatobá & 0,23 & 0,21 & 0,23 & 0,22 & 0,12 \\
\hline
\end{tabular}

Os valores da relação entre $f_{v 0, k}$ e $f_{c 0, k}$ propostos pela NBR $7190 / 97$ (item 6.3.3), diferem dos obtidos para as espécies de Angelim, Copaíba e Jatobá, seja para os CP's naturais, seja para os CP's preservados. Isto mostra a real necessidade de nova abordagem do assunto na próxima revisão do texto normativo.

Paralelamente, é possível observar que, exceto para o Ipê, as relações entre resistências características ao cisalhamento e à compressão paralela às fibras, nos CP's naturais, são superiores aos referidos valores para os CP's preservados com CCA.

\section{b) Espécies de reflorestamento}

\section{b.1) Eucalipto Grandis (Eucalyptus grandis)}

Nas Tabelas 107, 108 e 109, estão apresentados de forma resumida os resultados referentes às variações das propriedades mecânicas do Eucalipto Grandis, devidas ao efeito da penetração do preservativo e do processo de tratamento. Todavia, na Tabela 110, têm-se de forma sucinta, os valores referentes às relações entre resistências características ao cisalhamento e à compressão paralela às fibras.

TABELA 107 - Fatores K - valores relativos ao efeito da penetração do preservativo CCA e do processo de tratamento, com correção da umidade recomendada pela NBR 7190/97 e sugerida por LOGSDON (1998) Eucalipto Grandis

\begin{tabular}{c|c|c|c|c|c}
\hline Espécie & $\begin{array}{c}\text { Classe de resistência } \\
\text { (CP's naturais) }\end{array}$ & $\begin{array}{c}\text { Classe de resistência } \\
(\mathbf{C P} \text { 's preservados) }\end{array}$ & $\left(\mathbf{f}_{\mathbf{c} \mathbf{0}, \mathbf{C C A}} / \mathbf{f}_{\mathbf{c} \mathbf{0}, \mathbf{p}}\right)$ & $\left(\mathbf{f}_{\mathbf{v} \mathbf{0}, \mathbf{C C A}} / \mathbf{f}_{\mathbf{v} \mathbf{0}, \mathbf{p}}\right)$ & $\left(\mathbf{E}_{\mathbf{c} \mathbf{0}, \mathbf{C C A}} / \mathbf{E}_{\mathbf{c} \mathbf{0}, \mathbf{p}}\right)$ \\
\hline $\begin{array}{c}\text { E. Grandis } \\
\text { amostra 01) }\end{array}$ & C-40 & C-60 & 1,07 & 1,00 & 1,00 \\
$\begin{array}{c}\text { E. Grandis } \\
\text { (amostra 02) }\end{array}$ & C-60 & C-60 & 1,00 & 1,00 & 1,00 \\
\hline
\end{tabular}


TABELA 108 - Fatores K - valores relativos ao efeito da penetração do preservativo CCB e do processo de tratamento, com correção da umidade recomendada pela NBR 7190/97 - Eucalipto Grandis

\begin{tabular}{c|c|c|c|c|c}
\hline Espécie & $\begin{array}{c}\text { Classe de resistência } \\
\text { (CP's naturais) }\end{array}$ & $\begin{array}{c}\text { Classe de resistência } \\
\left(\mathbf{C P}{ }^{\prime} \text { p preservados) }\right.\end{array}$ & $\left(\mathbf{f}_{\mathrm{c} 0, \mathrm{CCA}} / \mathbf{f}_{\mathrm{c} 0, \mathrm{p}}\right)$ & $\left(\mathbf{f}_{\mathrm{v} 0, \mathrm{CCA}} / \mathbf{f}_{\mathrm{v} 0, \mathrm{p}}\right)$ & $\left(\mathbf{E}_{\mathrm{co}, \mathrm{CCA}} / \mathbf{E}_{\mathrm{co}, \mathrm{p}}\right)$ \\
\hline $\begin{array}{c}\text { E. Grandis } \\
\text { (amostra 02) }\end{array}$ & $\mathrm{C}-60$ & $\mathrm{C}-60$ & 1,06 & 1,00 & 1,00 \\
\hline
\end{tabular}

TABELA 109 - Fatores K - valores relativos ao efeito da penetração do preservativo CCB e do processo de tratamento, com correção da umidade sugerida por LOGSDON (1998) - Eucalipto Grandis

\begin{tabular}{|c|c|c|c|c|c|}
\hline Espécie & $\begin{array}{c}\text { Classe de resistência } \\
\text { (CP's naturais) }\end{array}$ & $\begin{array}{c}\text { Classe de resistência } \\
\text { (CP's preservados) }\end{array}$ & $\left(\mathbf{f}_{\mathrm{co}, \mathrm{CCA}} / \mathbf{f}_{\mathrm{c} 0, \mathrm{p}}\right)$ & $\left(\mathbf{f}_{\mathrm{v} 0, \mathbf{C C A}} / \mathbf{f}_{\mathrm{v} 0, \mathrm{p}}\right)$ & $\left(\mathbf{E}_{\mathrm{c} 0, \mathrm{CCA}} / \mathbf{E}_{\mathrm{c} 0, \mathrm{p}}\right)$ \\
\hline $\begin{array}{l}\text { E. Grandis } \\
\text { (amostra 02) }\end{array}$ & $\mathrm{C}-60$ & C-60 & 1,05 & 1,00 & 1,00 \\
\hline
\end{tabular}

Neste caso, em particular na avaliação de resistência à compressão paralela, foi detectado aumento decorrente da penetração, na amostra 01, da substância preservativa CCA, que fica retida na parede dos elementos anatômicos, e na amostra 02, do produto $\mathrm{CCB}$, que fica retido principalmente nos lúmens celulares.

É interessante notar que, para a amostra 01, a preservação permitiu o enquadramento na classe de resistência C-60, enquanto a madeira sem tratamento preservativo pertence à classe C-40.

Pelo que se apresenta na Tabela 110 (ver a seguir), os valores propostos pela NBR 7190/97 para relacionar $f_{v 0, k}$ e $f_{c 0, k}$, diferem dos obtidos para o Eucalipto Grandis.

TABELA 110 - Valores referentes às relações entre resistências características ao cisalhamento e à compressão paralela às fibras - Eucalipto Grandis

\begin{tabular}{|c|c|c|c|c|c|c|c|}
\hline \multirow{3}{*}{ Espécie } & \multicolumn{6}{|c|}{ Valores determinados } & \multirow{3}{*}{$\begin{array}{c}\begin{array}{c}\text { Valor } \\
\text { recomendado } \\
\text { (NBR 7190/97) }\end{array} \\
K\end{array}$} \\
\hline & \multicolumn{3}{|c|}{$\begin{array}{l}\text { Correção da umidade } \\
\text { (NBR 7190/97) }\end{array}$} & \multicolumn{3}{|c|}{$\begin{array}{l}\text { Correção da umidade } \\
\text { (LOGSDON (1998)) }\end{array}$} & \\
\hline & $K_{p}^{N B R}$ & $K_{C C A}^{N B R}$ & $K_{C C B}^{N B R}$ & $K_{p}^{L O G S D O N}$ & $K_{C C A}^{L O G S O N}$ & $K_{C C B}^{L O G S D O N}$ & \\
\hline $\begin{array}{c}\text { E. Grandis } \\
\text { (amostra 01) }\end{array}$ & 0,18 & 0,19 & ---- & 0,18 & 0,18 & ---- & 0,12 \\
\hline $\begin{array}{c}\text { E. Grandis } \\
\text { (amostra 02) }\end{array}$ & 0,18 & 0,17 & 0,15 & 0,17 & 0,17 & 0,14 & 0,12 \\
\hline
\end{tabular}

Também é possível observar pequena variação nas relações entre as resistências características ao cisalhamento paralelo e à compressão paralela às fibras, seja para CP's naturais, seja para CP's preservados. 


\section{b.2) Pinus Elliottii (Pinus elliottii)}

Nas Tabelas 111, 112, 113 e 114 estão apresentados de forma resumida os resultados referentes às variações das propriedades mecânicas do Pinus Elliottii, devidas ao efeito da penetração do preservativo e do processo de tratamento. Todavia, nas Tabelas 115 e 116, têm-se de forma sucinta, os valores referentes às relações entre resistências características ao cisalhamento e à compressão paralela às fibras e à tração paralela e à compressão paralela às fibras, respectivamente.

TABELA 111 - Fatores K - valores relativos ao efeito da penetração do preservativo CCA e do processo de tratamento, com correção da umidade recomendada pela NBR 7190/97 - Pinus Elliottii

\begin{tabular}{|c|c|c|c|c|c|}
\hline Espécie & $\begin{array}{c}\text { Classe de resistência } \\
\text { (CP's naturais e preservados) }\end{array}$ & $\left(\mathbf{f}_{\mathrm{c} 0, \mathrm{CCA}} / \mathbf{f}_{\mathrm{c} 0, \mathrm{p}}\right)$ & $\left(\mathbf{f}_{\mathrm{v} 0, \mathrm{CCA}} / \mathbf{f}_{\mathrm{v} \mathbf{p}, \mathrm{p}}\right)$ & $\left(\mathbf{f}_{\mathrm{t} 0, \mathrm{CCA}} / \mathbf{f}_{\mathrm{t0}, \mathrm{p}}\right)$ & $\left(\mathbf{E}_{\mathrm{c} 0, \mathrm{CCA}} / \mathbf{E}_{\mathrm{c} 0, \mathrm{p}}\right)$ \\
\hline $\begin{array}{l}\text { Pinus Elliottii } \\
\text { (amostra 01) }\end{array}$ & $\mathrm{C}-30$ & 1,17 & 1,00 & ----- & 1,00 \\
\hline $\begin{array}{l}\text { Pinus Elliottii } \\
\text { (amostra 01a) }\end{array}$ & $\mathrm{C}-30$ & ----- & ----- & 1,00 & ----- \\
\hline
\end{tabular}

TABELA 112 - Fatores K - valores relativos ao efeito da penetração do preservativo CCA e do processo de tratamento, com correção da umidade sugerida por LOGSDON (1998) - Pinus Elliottii

\begin{tabular}{|c|c|c|c|c|c|}
\hline Espécie & $\begin{array}{c}\text { Classe de resistência } \\
\text { (CP's naturais e preservados) }\end{array}$ & $\left(\mathbf{f}_{\mathrm{c} 0, \mathrm{CCA}} / \mathbf{f}_{\mathrm{c} 0, \mathrm{p}}\right)$ & $\left(\mathbf{f}_{\mathrm{v} 0, \mathrm{CCA}} / \mathbf{f}_{\mathrm{v} \mathbf{0}, \mathrm{p}}\right)$ & $\left(\mathbf{f}_{\mathrm{t} 0, \mathrm{CCA}} / \mathbf{f}_{\mathrm{t} 0, \mathrm{p}}\right)$ & $\left(\mathbf{E}_{\mathrm{c} 0, \mathrm{CCA}} / \mathbf{E}_{\mathrm{c} 0, \mathrm{p}}\right)$ \\
\hline $\begin{array}{l}\text { Pinus Elliottii } \\
\text { (amostra 01) }\end{array}$ & C-30 & 1,16 & 1,00 & ----- & 1,00 \\
\hline $\begin{array}{l}\text { Pinus Elliottii } \\
\text { (amostra 01a) }\end{array}$ & $\mathrm{C}-30$ & ----- & ----- & 1,00 & ----- \\
\hline
\end{tabular}

TABELA 113 - Fatores K - valores relativos ao efeito da penetração do preservativo CCB e do processo de tratamento, com correção da umidade recomendada pela NBR 7190/97 - Pinus Elliottii

\begin{tabular}{|c|c|c|c|c|c|}
\hline Espécie & $\begin{array}{c}\text { Classe de resistência } \\
\text { (CP's naturais e preservados) }\end{array}$ & $\left(\mathbf{f}_{\mathrm{c} 0, \mathrm{CCB}} / \mathbf{f}_{\mathrm{c} 0, \mathrm{p}}\right)$ & $\left(\mathbf{f}_{\mathrm{v} 0, \mathrm{CCB}} / \mathbf{f}_{\mathrm{v} 0, \mathrm{p}}\right)$ & $\left(\mathbf{f}_{\mathbf{t} 0, \mathbf{C C B}} / \mathbf{f}_{\mathbf{t} 0, \mathrm{p}}\right)$ & $\left(\mathbf{E}_{\mathrm{c} 0, \mathrm{CCB}} / \mathbf{E}_{\mathrm{c} 0, \mathrm{p}}\right)$ \\
\hline $\begin{array}{l}\text { Pinus Elliottii } \\
\text { (amostra 01a) }\end{array}$ & $\mathrm{C}-30$ & 1,55 & 1,00 & 1,00 & 1,00 \\
\hline $\begin{array}{l}\text { Pinus Elliottii } \\
\text { (amostra 01b) }\end{array}$ & $\mathrm{C}-30$ & 1,17 & 1,00 & ----- & 1,00 \\
\hline
\end{tabular}

TABELA 114 - Fatores K - valores relativos ao efeito da penetração do preservativo CCB e do processo de tratamento, com correção da umidade sugerida por LOGSDON (1998) - Pinus Elliottii

\begin{tabular}{|c|c|c|c|c|c|}
\hline Espécie & $\begin{array}{c}\text { Classe de resistência } \\
\text { (CP's naturais e preservados) } \\
\end{array}$ & $\left(\mathbf{f}_{\mathrm{c} 0, \mathrm{CCB}} / \mathbf{f}_{\mathrm{c} 0, \mathrm{p}}\right)$ & $\left(\mathbf{f}_{\mathrm{v} 0, \mathrm{CCB}} / \mathbf{f}_{\mathrm{v} \mathbf{0}, \mathbf{p}}\right)$ & $\left(\mathbf{f}_{\mathrm{t} 0, \mathrm{CCB}} / \mathbf{f}_{\mathbf{t} 0, \mathrm{p}}\right)$ & $\left(\mathbf{E}_{\mathrm{c} 0, \mathrm{CCB}} / \mathbf{E}_{\mathrm{c} 0, \mathrm{p}}\right)$ \\
\hline $\begin{array}{l}\text { Pinus Elliottii } \\
\text { (amostra 01a) }\end{array}$ & $\mathrm{C}-30$ & 1,52 & 1,00 & 1,00 & 1,00 \\
\hline $\begin{array}{l}\text { Pinus Elliottii } \\
\text { (amostra 01b) }\end{array}$ & $\mathrm{C}-30$ & 1,18 & 1,00 & ----- & 1,00 \\
\hline
\end{tabular}


Neste caso, assim como para a espécie anterior, observou-se influência apenas na avaliação da resistência à compressão paralela. Foi detectado um acréscimo da mesma ordem de grandeza, nas amostras 01 e $01 \mathrm{~b}$, decorrente da penetração da substância preservativa. Já, na amostra 01a, o acréscimo ocorreu de forma mais elevada. Vale ressaltar que, nesta amostra a retenção do preservativo foi bem superior se comparado com as demais amostras.

Pelo que se apresenta na Tabelas 115 (relação entre $f_{v 0, k}$ e $f_{c 0, k}$ ) (ver a seguir), o valor proposto pela NBR 7190/97 difere dos obtidos para o Pinus Elliottii, exceto para os CP's preservados com CCB.

TABELA 115 - Valores referentes às relações entre resistências características ao cisalhamento e à compressão paralela às fibras - Pinus Elliottii

\begin{tabular}{|c|c|c|c|c|c|c|c|}
\hline \multirow{3}{*}{ Espécie } & \multicolumn{6}{|c|}{ Valores determinados } & \multirow{3}{*}{$\begin{array}{c}\begin{array}{c}\text { Valor } \\
\text { recomendado } \\
\text { (NBR 7190/97) }\end{array} \\
K\end{array}$} \\
\hline & \multicolumn{3}{|c|}{$\begin{array}{l}\text { Correção da umidade } \\
\text { (NBR 7190/97) }\end{array}$} & \multicolumn{3}{|c|}{$\begin{array}{c}\text { Correção da umidade } \\
\text { (LOGSDON (1998)) }\end{array}$} & \\
\hline & $K_{p}^{N B R}$ & $K_{C C A}^{N B R}$ & $K_{C C B}^{N B R}$ & $K_{p}^{L O G S D O N}$ & $K_{C C A}^{L O G S D O N}$ & $K_{C C B}^{L O G S D O N}$ & \\
\hline $\begin{array}{l}\text { Pinus Elliottii } \\
\text { (amostra 01) }\end{array}$ & 0,22 & 0,22 & ----- & 0,22 & 0,21 & ----- & 0,15 \\
\hline $\begin{array}{l}\text { Pinus Elliottii } \\
\text { (amostra 01a) }\end{array}$ & 0,24 & ----- & 0,16 & 0,24 & ----- & 0,17 & 0,15 \\
\hline $\begin{array}{l}\text { Pinus Elliottii } \\
\text { (amostra 01b) }\end{array}$ & 0,23 & ----- & 0,20 & 0,23 & ----- & 0,19 & 0,15 \\
\hline
\end{tabular}

Da tabela acima, é possível observar uma variação nas relações entre as resistências características ao cisalhamento paralelo e à compressão paralela às fibras, seja para CP's naturais, seja para CP's tratados com preservativos do tipo $\mathrm{CCB}$

De acordo a Tabela 116 (relação entre $f_{t 0, k}$ e $f_{c 0, k}$ ) (ver a seguir), o valor proposto pela NBR 7190/97 difere dos obtidos para o Pinus Elliottii, exceto para os CP's naturais.

TABELA 116 - Valores referentes às relações entre resistências características à compressão e à tração paralela às fibras - Pinus Elliottii

\begin{tabular}{c|c|c|c|c|c|c|c}
\hline \multirow{2}{*}{ Espécie } & \multicolumn{4}{|c|}{ Valores determinados } & \multicolumn{1}{c}{$\begin{array}{c}\text { Valor } \\
\text { recomendado } \\
\text { (NBR 7190/97) }\end{array}$} \\
\cline { 2 - 7 } & \multicolumn{2}{|c|}{$\begin{array}{c}\text { Correção da umidade } \\
\text { (NBR 7190/97) }\end{array}$} & \multicolumn{2}{c}{$\begin{array}{c}\text { Correção da umidade } \\
\text { (LOGSDON (1998)) }\end{array}$} & $K$ \\
\cline { 2 - 7 } & $K_{p}^{N B R}$ & $K_{C C A}^{N B R}$ & $K_{C C B}^{N B R}$ & $K_{p}^{L O G S D O N}$ & $K_{C C A}^{L O G S D O N}$ & $K_{C C B}^{L O G S O N}$ & $K$ \\
\hline $\begin{array}{c}\text { Pinus Elliottii } \\
\text { (amostra 01a) }\end{array}$ & 0,74 & 0,96 & 1,32 & 0,74 & 0,96 & 1,31 & 0,77 \\
\hline
\end{tabular}


Segundo a Tabela 116, também é possível observar grande variação nas relações entre as resistências características à compressão paralela e à tração paralela às fibras, seja para CP's naturais, seja para $\mathrm{CP}$ 's preservados com $\mathrm{CCA}$ e CCB. 


\section{REFERÊNCIAS BIBLIOGRÁFICAS}

AGUILLAR F ${ }^{\mathrm{O}}$, D. (1986). Combustibilidade e tratamento ignífugo da madeira. São Carlos. 99p. Dissertação (Mestrado) - Escola de Engenharia de São Carlos, Universidade de São Paulo.

ANDRADE, E.N. (1911). Manual do plantador de Eucaliptos. São Paulo, Typographia Brazil de Rothschild, 343p.

ANDRADE, E.N. (1936). Instruções para a cultura do Eucalipto. São Paulo, Companhia Paulista de Estradas de Ferro, 59p.

ANDRADE, E.N. (1961). O Eucalipto.2ed. São Paulo, Companhia Paulista de Estradas de Ferro, 667p.

ARRUDA VEIGA, A. (1981). Cultura de Pinus. São Paulo, Instituto Florestal (Atualização do texto do Boletim Técnico $\mathrm{n}^{\mathrm{o}}$ 5).

ASSOCIAÇÃO BRASILEIRA DE NORMAS TÉCNICAS (1997). NBR - 7190 Projeto de estruturas de madeira. Rio de Janeiro. (1973). EB 474 - Moirões de madeira preservada para cercas. São Paulo. (1973). NBR 6229 - Postes de Eucalipto preservados sob pressão. São Paulo.

BARALDI, L.T. (1996). Método de ensaio de ligações em estruturas de madeira por chapas com dentes estampados. São Carlos. 117p. Dissertação (Mestrado) - Escola de Engenharia de São Carlos, Universidade de São Paulo. 
BARISKA, M.; PIZZI, A.; CONRADIE, W.E. (1988). Structural weakening of CCA-treated timber. Holzforschung, v.42, n.5. p.339-345, Mai.

BARNES, H.M. et al. (1993). Strength properties of ACQ-treated Southern Pine lumber. In: AMERICAM WOOD PRESERVERS' ASSOCIATION, Woodstock, MD, 1993. Proceedings. Woodstock, v.89, p.51-60.

BARROS Jr., O. (1991). Algumas considerações sobre a pré-fabricação de estruturas de madeira para coberturas . São Carlos. 143p. Dissertação (Mestrado) Escola de Engenharia de São Carlos, Universidade de São Paulo.

BENDTSEN, B.A; GJOVIK, L.R.; VERRILL, S. (1983). The mechanical properties of salt-treated longreaf Pine. Res. Pap. (FPL-434). Madison, WI: U.S. Departament of Agriculture, Forest Service, Forest Products Laboratory.

BENEVENTE, V.A. (1995). Durabilidade em construções de madeira - uma questão de projeto. São Carlos. 231p. Dissertação (Mestrado) - Escola de Engenharia de São Carlos, Universidade de São Paulo.

BERTOLANI, F. (1978). As experiências com Pinus no Brasil. In: ENCONTRO NACIONAL DE REFLORESTADORES, 4., Campo Grande, BR, 1978. Anais. São Paulo, UNIPRESS. p.33-36.

BORTOLETTO Jr., G. (1993). Indicações para utilização da madeira de seis espécies e variedades de Pinus aplicada na construção civil. São Carlos. 119p. Dissertação (Mestrado) - Escola de Engenharia de São Carlos, Universidade de São Paulo.

BROCHARD, F.X. (1960). Bois et charpente en bois. Paris, Éditions Eyrolles. 
BURMESTER, A.; BECKER, G. (1963). Investigations on the influence of wood preservatives on the strength of wood. Holz als Roh-und Werkstoff, v.21, n.10, p.393409, Out.

BURMESTER, A. (1970). Long term effects of wood preservatives of physical and mechanical properties of wood. Holz als Roh-und Werkstoff, v.28, n.12, p.478-485, Dez.

CARPANEZZI, A. A. et al. Zoneamento ecológico para plantios florestais no Estado do Paraná. Brasília, EMBRAPA-DDT, 1986.

CAVALCANTE, M.S. (1982). Deterioração biológica e preservação de madeiras. São Paulo, IPT, Divisão de Madeiras (Pesquisa \& Desenvolvimento, n.8). (1983). Implantação e desenvolvimento da preservação de madeira no Brasil. São Paulo, IPT, Divisão de Madeiras (Pesquisa \& Desenvolvimento, n.14).

CAMPOS, C.S. (1998). Resultados preliminares da variação da absorção do CCA tipo A em Brosimun rubescens Taub. Moraceae (Pau-rainha). São Paulo, ABPMIPT, Divisão de Produtos Florestais, (Boletim Técnico ABPM, n.31).

CARTWRIGHT, K.G.; FINDLAY, W.P.K. (1958). Decay of timber its prevention. 2.ed. London, Her Majesty’s Stationery.

CÉSAR, S.F. (1991). As estruturas Hauff de madeira no Brasil . São Carlos. 197p. Dissertação (Mestrado) - Escola de Engenharia de São Carlos, Universidade de São Paulo.

COCKCROFT, R.; HENNINGSSON, B.O. (1983). The global needs of wood preservation. The Internetional Journal of Wood Preservation, v.3, n.2, p.65-71.

COCKCROFT, R. (1977). Preservative treatments for constructional timber. London, Building Research Establishment, Princes Risborough Laboratory.

COSTA, A.F. (1981). Deterioração e preservação da madeira. Brasília, IBDF-LPF. 
COULSON, R.N.; LUND, A.E. (1973). The degradation of wood by insects. In: WOOD DETERIORATION AND IT'S PREVENTION BY PRESERVATIVE TREATMENTS. New York, NY, Syracuse University Press, 1973. Proceedings. New York, Syracuse Wood Science Series. v.1, p.277-305.

DIVISÃO DE MADEIRAS (1985). Madeira - o que é e como pode ser processada e utilizada. São Paulo, ABPM-IPT, (Boletim Técnico ABPM, n.37).

EATON, M.L.; DRELICHARZ, J.A.; ROE Jr., T (1978). The mechanical properties of preservative treated marine piles - results of limited full scale testing. Port Hueneme, CA, Civil Engineering Laboratory TN No N-1535. Nov.

EGGLESTON, R.C. (1952). Pole strength tests. Journal Forest Products Res. Soc., v.2, n.1, p.3-24, Jan.

FOREST PRODUCTS LABORATORY (1974). Wood handbook: wood as na engineering material. Forest Products Laboratory - Forest Service - U.S. Departament of Agriculture, (Agriculture Handbook, 72). Washington, D.C.

FREITAS, A.R.; GERALDO, F.C. (1982). Preservação de madeiras no Brasil 1978/79. São Paulo, IPT, Divisão de Madeiras (Pesquisa \& Desenvolvimento, n.5).

FURIATI, M. (1983). Classificação estrutural de peças de madeira. In: ENCONTRO BRASILEIRO DE MADEIRA E ESTRUTURAS DE MADEIRA, 1., São Carlos, BR, 1983. Anais. São Carlos, Escola de Engenharia de São Carlos, Universidade de São Paulo. v.Características, p.1-30.

FUSCO, P.B. (1976). Estruturas de concreto - Fundamentos estatísticos da segurança das estruturas. 1.ed. São Paulo, Ed. McGraw-Hill. 1v.

GALVÃO, A.P.M. (1976). Processos práticos para preservar a madeira. Piracicaba, ESALQ-USP. 
GOLFARI, L. et al. (1978). Zoneamento ecológico esquemático para o reflorestamento no Brasil. Brasília, Ministério da Agricultura-PRODEPEF-PNDUFAO-IBDF-45 (Série Técnica n.11).

GRAHAM, R.D. (1973). History of wood preservation. In: WOOD DETERIORATION AND IT'S PREVENTION BY PRESERVATIVE TREATMENTS. New York, NY, Syracuse University Press, 1973. Proceedings. New York, Syracuse Wood Science Series. v.2 p.1-120.

GREGORY, D.S. (1915). Strength tests of structural timber treated with commercial preservatives. Bull. 186. Washington, DC: U.S. Departament of Agriculture.

GUI, Y.Q.; NICHOLAS, D.D.; CRAWFORD, D. (1996). A miniature mechanical apparatus and test protocolo for bending and crushing tests in wood preservation research. Forest Products Journal, v.46, n.10, p.77-80, Oct.

HARTFORD, W.H. (1976). The environmental impact of wood preservation. In: AMERICAM WOOD PRESERVERS' ASSOCIATION, Woodstock, US, 1976. Proceedings, Woodstock, AWPA, 9p.

HARTFORD, W.H.; COLLEY, R.H. (1980). The service life of wood treated, the log-probability model, and human carcinogenisis. In: AMERICAM WOOD PRESERVERS' ASSOCIATION, Woodstock, US, 1980. Proceedings, Woodstock, AWPA, 9p. 
HELLMEISTER, J.C. (1983). Madeiras e suas características. In: ENCONTRO BRASILEIRO DE MADEIRA E ESTRUTURAS DE MADEIRA, 1., São Carlos, 1983. Anais. São Carlos, Escola de Engenharia de São Carlos, Universidade de São Paulo, v.Características, p.1-37.

(1973). Sobre a determinação das características físicas da madeira. São Carlos. 119p. Tese (Doutorado) - Escola de Engenharia de São Carlos, Universidade de São Paulo.

HESP, T.; WATSON, R.W. (1964). The effects of water-born preservatives applied by vacuum pressure methods on the strngth properties of wood. Wood, v.29, n.6, p.50-53, Jun.

HUNT, G.; GARRATT, G.A. (1953). Wood preservation. 2.ed. New York, Ed. McGraw Hill. 1v.

HUNT, G.; GARRATT, G.A. (1962). Preservacion de la madera. Trad. por Adelardo Sanchis Batalla. Barcelona, Salvati Editores.

INFORMATIVO QUADRIMESTRAL SOBRE O SETOR FLORESTAL PAULISTA (1994/95). São Paulo, v.2, n.6, Florestar Estatístico.

INSTITUTO DE PESQUISAS TECNOLÓGICAS DO ESTADO DE SÃO PAULOIPT. (1956). Madeiras nacionais - tabelas de resultados de ensaios fisicos $e$ mecânicos. São Paulo, IPT (Boletim Técnico, n.31).

JESUS, L.L.H. (1987). Preservação da madeira de Pinus spp para a construção civil. São Carlos. 99p. Dissertação (Mestrado) - Escola de Engenharia de São Carlos, Universidade de São Paulo.

JESUS, J.M.H. (1986). Secagem ao ar livre e secagem solar de madeiras aplicadas na construção civil. São Carlos. 152p. Dissertação (Mestrado) - Escola de Engenharia de São Carlos, Universidade de São Paulo. 
JUNTA DEL ACUERDO DE CARTAGENA-JUNAC. (1988). Manual del grupo andino para la preservacion de maderas. Lima, PADT-REPORT-JUNAC.

KARLSEN, G.G. (1967). Wooden structures. Moscou, Mir Publishers.

KOLLMANN, F.E.P.; COTÊ Jr., W. (1968). Principles of wood science and technology. Heidelberg, Springer-verlag. 1v.

LELIS, A.T. (1975/76). Cupins-prevenção e irradicação. São Paulo, ABPM, Preservação de Madeiras, p.51-58.

LEPAGE, E.S. et al. (1986). Manual de preservação de madeiras. São Paulo, IPT, v.1 e v.2.

LOGSDON, N.B. (1998). Influência da umidade nas propriedades de resistência e rigidez da madeira. São Carlos. 200p. Tese (Doutorado) - Escola de Engenharia de São Carlos, Universidade de São Paulo.

LOGSDON, N.B. (1995). Variação da tensão resistente ao cisalhamento paralelo às fibras em uma peça de dimensões comerciais de Amescla (Trattinickia burserifolia) In: ENCONTRO BRASILEIRO DE MADEIRA E ESTRUTURAS DE MADEIRA, 5., São Carlos, BR, 1995. Anais. Belo horizonte, Universidade Federal de Minas Gerais, v.5, p.235-244.

MAINIERI, C.; CHIMELO, J.P. (1989). Fichas de características das madeiras brasileiras. São Paulo, IPT, Divisão de Madeiras.

MELO, J.E. (1981). Madeiras que substituem o Pinho-do-Paraná em formas para concreto. Brasília, IBAMA-Ministério do Interior-LPF, v.01, n.1. 
MELO, J.E. et al. (1997). Madeiras da Amazônia - características e utilização. Brasília, Ministério do Meio Ambiente, dos Recursos Hídricos e da Amazônia LegalIBAMA- LPF, 3v, Amazônia Oriental.

MEYER, P.L. (1983). Probabilidade - Aplicações à estatística. 2.ed. São Paulo, Ao Livro Técnico S.A.

MINISTÉRIO DA AGRICULTURA - INSTITUTO BRASILEIRO de DESENVOLVIMENTO FLORESTAL - LABORATÓRIO de PRODUTOS FLORESTAIS (1981). Potencial madeireiro do Grande Carajás. Brasília-DF.

MITCHELL, P.H.; BARNES, H.M. (1986). Effects of drying temperature on the clear wood strength of Southern Pine treated with CCA-type A. Forest Products Journal, v.36, n. 3, p.8-12, Mar.

MONTANA QUÍMICA S. A. (1991). Biodeterioração e preservação de madeiras. São Paulo, Montana Química S. A.

MOREY, P.R. (1981). O crescimento das árvores. São Paulo, EPU/EDUSP.

MORGAN, J.W.W. (1973). Proposed method for assessing the resistence of timber to impregnation with preservatives under pressure. In: IUFRO MEETING DIVISION, 5, Pretoria, 1973. Proceedings. Pretoria, v.4, p.1532-1547.

NOGUEIRA, M.C.J.A. (1991). Indicações para o emprego de 16 espécies de Eucalipto na construção civil. São Carlos. 150p. Dissertação (Mestrado) - Escola de Engenharia de São Carlos, Universidade de São Paulo.

PERRIN, P.W. (1978). Review of incising and its effects on strength and preservatives treatment of wood. Forest Products Journal. v.28, n.9, p.27-33, Sept. 
PINHEIRO, R.V. (1996). Emprego da madeira do gênero Pinus na construção de estruturas de cobertura. São Carlos. 163p. Dissertação (Mestrado) - Escola de Engenharia de São Carlos, Universidade de São Paulo.

PINHEIRO, R.V.; ROCCO LAHR, F.A. (1996). Emprego de espécies de madeiras alternativas em estruturas de cobertura para construções rurais. In: II CONGRESO INTERNACIONAL/IV CONGRESO ARGENTINO DE INGENIERÍA RURAL, 4., Neuquem, AR, 1996. Anais. Neuquem, Facultad de Ciencias Agrarias, Universidad Nacional del Camahue, 1996.

PINHEIRO, R.V et al. (1993). Espécies de madeiras alternativas para a construção de estruturas de cobertura. In: XXVI JORNADAS SUDAMERICANAS DE INGENIERÍA ESTRUCTURAL, 4, Montevideo, UR, 1993. Anais. Montevideo, Facultad de Ingeniería, Instituto de Estructuras y Transporte, v.5, p. 313-384.

PINHEIRO, R.V.; BARROS, O.Jr. ; LAHR, F.A.R. (1993). Arco treliçados com banzos paralelos em madeira de espécies alternativas. In: ENCONTRO REGIONAL DE MADEIRA E ESTRUTURAS DE MADEIRA, 1., São Paulo, BR, 1993. Anais. São Paulo, Escola Politécnica, Universidade de São Paulo, v.1, p.25-26. (1992). Emprego da madeira de Pinus na construção de estruturas de coberturas. In: ENCONTRO BRASILEIRO DE MADEIRA E ESTRUTURAS DE MADEIRA, 4., São Carlos, BR, 1992. Anais. São Carlos, Escola de Engenharia de São Carlos, Universidade de São Paulo, v.3, p.229-234.

PONCE, E.S.; WATAI, L.T. (1985). Manual de secagem de madeiras. Brasília, STIIPT. 
RAIMBAULT, G.; CARLOS, V.J. (MONTANA QUÍMICA S.A.) (1983). A preservação de madeira aplicada às estruturas. In: ENCONTRO BRASILEIRO DE MADEIRA E ESTRUTURAS DE MADEIRA, 1., São Carlos, BR, 1983. Anais. São Carlos, Escola de Engenharia de São Carlos, Universidade de São Paulo, v.Tópicos Especiais, p.1-47.

RESCH, H.; PARKER, R. (1982). Strength and stiffness of preservative-treated marine piles. Wood and Fiber, v.14, n.4, p.310-319, Apr.

RICHARDSON, B.A. (1978). Wood preservation. Lancaster, The construction Press.

RITTER, M.A. et al. (1996). Effects of preservative treatment on bar force in stresslaminated bridge decks. National Conference on Wood Transportation Structures, Madison, WI. Gen. Tech. Rep (FPL-GTR-94). Madison,: U.S. Departament of Agriculture, Forest Service, Forest Products Laboratory, p.245-251.

ROCCO LAHR, F.A. (1990). Considerações a respeito da variabilidade de propriedades de resistência e de elasticidade da madeira. São Carlos. 161p. Tese (Livre-docência) - Escola de Engenharia de São Carlos, Universidade de São Paulo.

ROCCO LAHR, F.A. (1983). Aspectos históricos do emprego das estruturas de madeira para coberturas. In: ENCONTRO BRASILEIRO DE MADEIRA E ESTRUTURAS DE MADEIRA, 1., São Carlos, BR, 1983. Anais. São Carlos, Escola de Engenharia de São Carlos, Universidade de São Paulo, v.Telhados, p.1-13.

ROCCO LAHR, F.A. (1989). Propriedades físicas, de resistência e de elasticidade de espécies de madeira para emprego em estruturas. In: ENCONTRO BRASILEIRO DE MADEIRA E ESTRUTURAS DE MADEIRA, 3., São Carlos, BR, 1989. Anais. São Carlos, Escola de Engenharia de São Carlos, Universidade de São Paulo, v.3, p.59-70. 
ROCCO LAHR, F.A.; BARROS, O.Jr. (1992). Propriedades estruturais de três espécies alternativas de madeira - parte 1 In: ENCONTRO BRASILEIRO DE MADEIRA E ESTRUTURAS DE MADEIRA, 4., São Carlos, BR, 1992. Anais. São Carlos, Escola de Engenharia de São Carlos, Universidade de São Paulo, v.5, p.7984.

RONAI, F. (1989). Effect of wood preservatives on the strength propoerties of wood. In: MEETING INTERNATIONAL COUNCIL FOR BUILDING RESEARCH STUDIES AND DOCUMENTATION, 22., East Berlin, GE, 1989. Proceedings, East Berlin, p.1-3.

SALES, A. (1991). Característica de resistência mecânica de algumas espécies de Eucalipto do Estado de São Paulo. São Carlos. 219p. Dissertação (Mestrado) Escola de Engenharia de São Carlos, Universidade de São Paulo.

SCHEFFER, T.C. (1973). Microbiological degradation. In: WOOD DETERIORATION AND IT'S PREVENTION BY PRESERVATIVE TREATMENTS. New York, NY, Syracuse University Press, 1973. Proceedings. New York, Syracuse Wood Science Series. v.1, p.31-106.

SWIDERSKI, J. (1968). Importance of wood preservation in tropical countries. Unysilva, Roma, v.90, p.16-22.

SMITH, M.S. et al. (1993). Supercritical fluid (SCF) treatment: its effect on bending strength and stiffness of Ponderosa Pine sapwood. Wood and Fiber Science, v.25, n.2, p.119-123 Feb.

SMITH, R.S. (1974). Principles of biological attack. In: ARCHITECTURAL OPPORTUNITIES SEMINAR - the use and misuse of wood in construction and architectural design. Vancouver, CAN: Foresty Service, Western Forest Products Laboratory, n.2, p.3-8. 
SMITH, W.B. et al. (1996). Preservative treatment of Red Maple. Forest Products Journal, v.46, n.3, p.35-41, Mar.

SOCIEDADE BRASILEIRA DE SILVICULTURA (SBS-2000). Oferta e demanda de madeira de florestas plantadas. Curitiba-PR.

SOUZA, M.H. (1997). Incentivo ao uso de novas madeiras para a fabricação de móveis. Brasília, Ministério do Meio Ambiente, dos Recursos Hídricos e da Amazônia Legal-IBAMA-LPF.

SZUCS, C.P. (1992). Usando o Pinus: uma questão de desenho. In: ENCONTRO BRASILEIRO DE MADEIRA E ESTRUTURAS DE MADEIRA, 4., São Carlos, BR, 1992. Anais. São Carlos, Escola de Engenharia de São Carlos, Universidade de São Paulo, v.2, p.177-186.

TAVARES, O.D.P. (1984). O incentivo ao reflorestamento no brasil. In: SEMINÁRIO SOBRE EXPORTAÇÃO DE MADEIRAS TROPICAIS, 2., São Luiz, 1984. Anais. São Luiz, Maranhão, 7 p.

TAYLOR, F.A. (1974). Ground contact and wood foundations. In: ARCHITECTURAL OPPORTUNITIES SEMINAR - the use and misuse of wood in construction and architectural design. Vancouver, CAN: Foresty Service, Western Forest Products Laboratory, n.2, p.3-8.

TERENTJEV, V. (1972). Effects of KM-5 preservative on the mechanical properties of wood. Derevoobrabalyvayushchaya Promphlennost, v.21, n.8, p.15-16, Ago.

THOMPSON, W.S. (1980). Effects of preservative treatment and exposure conditions on the mechanical properties and performance of wood. In: WORKSHOP ON HOW THE ENVIRONMENT AFFECTS LUMBER DESIGN: ASSESSMENTS AND RECOMMENDATIONS. FPL, Madison: U.S. Departament of Agriculture, Forest Service, Forest Products Laboratory, p.36-51. 
TIMBER RESEARCH AND DEVELOPEMENT ASSOCIATION-TRADA. (1991). Timber - their properties and uses. London, TRADA (Wood Information, Section 2/3 Sheet 10).

TOMAZELLO Fº , M. (1996). Formação e anatomia da madeira - exercícios práticos . Piracicaba, ESALQ-USP.

TOOLE, E.R. (1971). Evaluation of wood preservatives using crushing strength. Separata of Phitopathology, v.61, n.2, p.182-183.

TSOUMIS, G. (1991). Science and tecnology of wood - structure, properties and utilization. New York, Ed. Van Nostrand Reinhold. Cap.19, p.293-308: Utilization preservative treatment.

UNIVERSIDADE DE SÃO PAULO. Escola de Engenharia de São Carlos (1996). Diretrizes para elaboração de dissertações e teses na EESC-USP. 2.ed. São Carlos, EESC-USP.

UJVARI, W. Z. Ligações em madeira, feitas com conectores dentados “Gang-Nail”. In: ENCONTRO BRASILEIRO DE MADEIRA E ESTRUTURAS DE MADEIRA, 1., São Carlos, BR, 1983. Anais. São Carlos, Escola de Engenharia de São Carlos, Universidade de São Paulo, Ligações, p.01-25.

WANGAARD, F.F. (1950). The mechanical properties of wood. 1.ed. New York, Ed. John Wiley \& Sons. 1v.

WILCOX, W.W. (1973). Degradation in relation to wood structure. In: WOOD DETERIORATION AND IT'S PREVENTION BY PRESERVATIVE TREATMENTS. New York, NY, Syracuse University Press, 1973. Proceedings. New York, Syracuse Wood Science Series. v.1, p.107-148. 
WILKINSON, J.G. (1979). Industrial timber preservation. London. Associated Bussiness Press.

WINANDY, J.E. (1996). Effects of treatment, incising and drying on mechanical properties of timber. National Conference on Wood Transportation Structures, Madison. Gen. Tech. Rep (FPL-GTR-94). Madison,: U.S. Departament of Agriculture, Forest Service, Forest Products Laboratory, p.178-185.

WINANDY, J.E. (1995a). Effects of waterborne preservative treatment on mechanical properties; a review. In: AMERICAM WOOD PRESERVERS' ASSOCIATION, Woodstock, US, 1995. Proceedings, Woodstock, AWPA, v.91, p.17-33.

WINANDY, J.E. (1995b). Effects of moisture content on strength of CCA-treated lumber. Wood and Fiber Science, v.27, n.2, p.168-177, Feb.

WINANDY, J.E. (1995c). Influence of time-to-failure on strength of CCA-treated lumber. Forest Products Journal, v.45, n.2, p.82-85, Feb.

WINANDY, J.E. (1989). The effects of CCA preservative treatment and redrying on bending properties of two grades of Southern Pine 2 by 4 lumber. Forest Products Journal, v.39, n.9, p.14-21, Sept.

WINANDY, J.E.; LEBOW, S.T. (1997). Effects of ammoniacal copper citrate preservative treatment and redrying on bending properties of two grades of Southern Pine 2 by 4 lumber. Forest Products Journal, v.47, n. 7/8, p.91-99, Jul/Ago.

WINANDY, J.E.; BOONE, R.S.; FULLER, J.J. (1995). Effects of redrying schedule on preservative fixation and strength of CCA-treated lumber. Forest Products Journal, v.45, n. 9, p.65-73, Sept. 
WINANDY, J.E.; BOONE, R.S. (1988). The effects of CCA preservative treatment and redrying on the bending properties of 2x6 Southern Pine lumber. Wood and Fiber Science, v.20, n.3, p.350-364, Mar.

WINANDY, J.E.; BARNES, H.M. (1986). The effects of drying and preservatives on the properties of treated wood. In: AMERICAM WOOD PRESERVERS' ASSOCIATION, Woodstock, US, 1986. Proceedings. Woodstock, AWPA, v.82, p.95-105.

YAMAMOTO, A.C. (1974). Secagem de madeira e preservação de madeira. São Paulo, Boletim Técnico, v.2, n.1, p.85-145. 